\title{
Eixos
}

Multifuncionais:

Infraestrutura Verde e

Serviços Ecossistêmicos Urbanos aplicados ao córrego Mandaqui, São Paulo, SP.

Taícia Helena Negrin Marques

Programa de pós-graduação em Arquitetura e Urbanismo Universidade de São Paulo

São Paulo

2020 


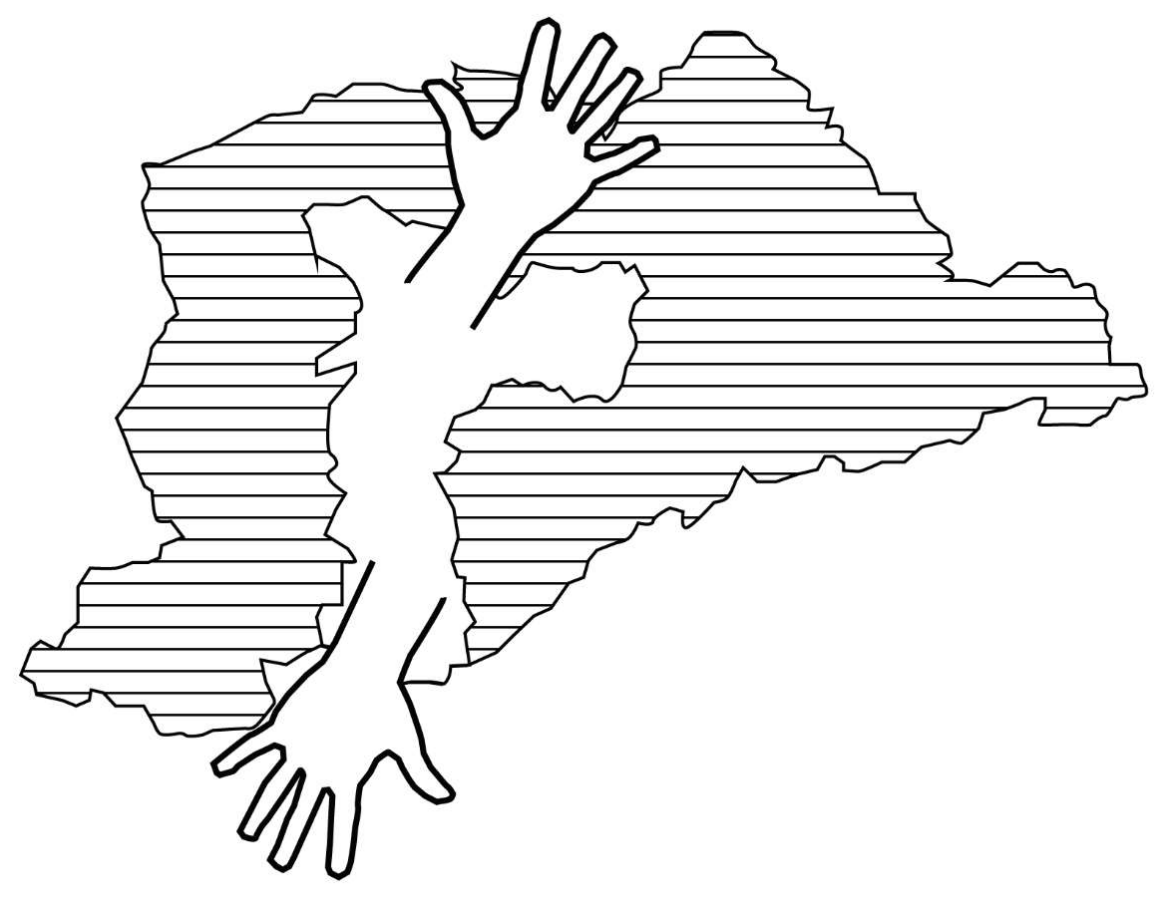




\section{Eixos \\ Multifuncionais: \\ Infraestrutura Verde e \\ Serviços Ecossistêmicos Urbanos aplicados ao córrego Mandaqui, São Paulo, SP.}

\section{Versão Corrigida}

EXEMPLAR REVISADO E ALTERADO EM RELAÇÃO À VERSÃO ORIGINAL, SOB RESPONSABILIDADE DO(A) AUTOR(A) E ANUÊNCIA DO(A) ORIENTADOR(A). A versão original, em formato digital, ficará arquivada na Biblioteca da Faculdade. São Paulo, 15 de julio de 2020.

Tese apresentada ao Programa de Pós-graduação em Arquitetura e Urbanismo, área de concentração Paisagem e Ambiente, da Universidade de São Paulo para a obtenção do título de Doutora em Arquitetura e Urbanismo.

Taícia Helena Negrin Marques

Orientadora: Maria de Assunção Ribeiro Franco

São Paulo

2020 
Autorizo a reprodução e divulgação total ou parcial deste trabalho, por qualquer meio convencional ou eletrônico, para fins de estudo e pesquisa, desde que citada a fonte.

\section{Catalogação na Publicação \\ Serviço Técnico de Biblioteca}

Faculdade de Arquitetura e Urbanismo da Universidade de São Paulo

Marques, Taícia Helena Negrin

Eixos Multifuncionais: Infraestrutura Verde e Serviços

Ecossistêmicos urbanos aplicados ao córrego Mandaqui, São Paulo, SP. / Taícia Helena

Negrin Marques; orientador Maria de Assunção Ribeiro Franco. - São Paulo, 2020. 217 f..

Tese (Doutorado) - Faculdade de Arquitetura e Urbanismo da Universidade de São Paulo. Área de concentração: Paisagem e Ambiente.

1. Infraestrutura Verde. 2. Serviços Ecossistêmicos Urbanos. 3. Eixo Multifuncional. 4. Drenagem Sustentável.

I. Franco, Maria de Assunção Ribeiro, orient. II. Título. 


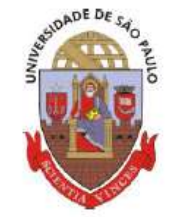

\section{Universidade de São Paulo \\ Faculdade de Arquitetura e Urbanismo}

Fanus

CERTIFICADO DE DEFESA

CERTIFICO, para os devidos fins, que Sr(a). Taicia Helena Negrin Marques, número USP 9592004, defendeu no dia 05 de junho de 2020, no Programa de Arquitetura e Urbanismo do(a) Faculdade de Arquitetura e Urbanismo da Universidade de São Paulo, a Tese de Doutorado intitulada:

"Eixos multifuncionais: infraestrutura verde e serviços ecossistêmicos urbanos aplicados ao córrego Mandaqui, São Paulo, SP"

CERTIFICO, ainda, que o(a) aluno(a) faz jus ao título de Doutora em Ciências - Área: Paisagem e Ambiente, tendo sido a ata da Comissão Julgadora homologado pela Comissão de Pós-Graduação, em 22 de junho de 2020.

São Paulo, 25 de junho de 2020.

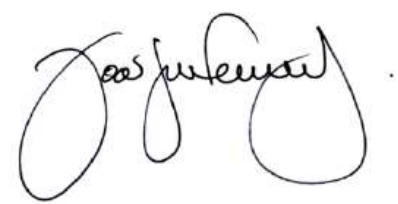

Prof. Dr. João Sette Whitaker Ferreira Presidente da CPG 


\section{AGRADECIMENTOS}

À Profa. Dra. Maria de Assunção Ribeiro Franco, pelo suporte ao longo de todo o processo de tese e por sempre me fazer perguntas. Ao Prof. Dr. Paulo Pellegrino, por me abrir as portas do Labverde ainda em 2013, e a todos os pesquisadores que passaram pelo laboratório desde então, em especial à Carme Machí, com quem tive as primeiras discussões sobre a Infraestrutura Verde em São Paulo, Tatiana Batistella, Sarah Suassuna e Natalia Carvalho. Ao Prof. Dr. Marcelo Giacaglia e à equipe do CESAD- FAU pelo apoio com a utilização das ferramentas de geoprocessamento.

À equipe de trabalho do Projeto Resiliência Urbana, por possibilitar o contato com outras visões de mundo e teorias. À SIURB, por disponibilizar a utilização dos dados do Caderno de Drenagem do Mandaqui na tese.

À Fundação Centro Tecnológico de Hidráulica, à Oscip Associação Águas Claras do Rio Pinheiros e a toda equipe de trabalho envolvida no Projeto Jaguaré, em especial à Daniela Rizzi, Ana Paula Brites e Érika Tominaga, pelas inúmeras discussões e por tornar o processo multidisciplinar, interdisciplinar. Ao Prof. Dr. José Rodolfo Scarati Martins, pela coordenação do Projeto e por apoiar a doutoranda no recebimento de bolsa de estudos entre abril/2016 e julho/2017. O Projeto Jaguaré não teria sido possível sem o apoio do Fundo Estadual de Recursos Hídricos de São Paulo (FEHIDRO).

A mis compañeros del Departamento de Ordenamiento Territorial y Construcción (DOT.C), por haberme acogido tan amablemente. Al DOT.C y a la Facultad de Ingeniería Agrícola de la Universidad Nacional Agraria La Molina- UNALM, por el apoyo en concluir la tesis.

À Profa. Dra. Vera Luz por ter me ensinado o poder da narrativa. Ao Prof. Dr. José Guilherme Schutzer pelo aporte metodológico. Aos dois, pelos comentários construtivos durante a qualificação da tese.

À Marli e ao Sidnei, mãe e pai, e à minha família brasileira, de sangue e de laços, pelo apoio incondicional, sempre. Ao Antônio e ao André por me ouvirem ativamente. A mi familia peruana, por el cariño y soporte.

A Agustín, por su amor. Su pasión por investigar es una inspiración para mí. 


\section{RESUMO}

MARQUES, T.H.N. Eixos Multifuncionais: Infraestrutura Verde e Serviços Ecossistêmicos Urbanos aplicados ao córrego Mandaqui, São Paulo, SP. Tese de doutorado, Programa de Pós-graduação em Arquitetura e Urbanismo, área de concentração Paisagem e Ambiente, da Universidade de São Paulo, 2020.

O saneamento e a ocupação das várzeas foram estratégicos para que a cidade de São Paulo se tornasse a capital metropolitana e estatal economicamente mais importante do país. Avenidas radiais e perimetrais, capazes de dar suporte ao crescimento contínuo da cidade em direção às periferias acompanharam as canalizações ou supressões completas dos rios, córregos e áreas verdes das várzeas, afastando a população e ocasionando distintos impactos ambientais. Partimos do pressuposto de que os fundos de vale são áreas de alto desempenho e refletem a oportunidade de serem convertidos em Eixos Multifuncionais capazes de estruturar uma rede conectada de espaços abertos, catalisadora do verde e do azul no interior da trama urbana, oferecendo diversos serviços ecossistêmicos. Como suporte a esta afirmação, seis princípios da Infraestrutura Verde foram definidos e integrados ao conceito de Serviços Ecossistêmicos, aplicados ao estudo de caso do córrego Mandaqui, São Paulo, SP, simulados a partir da proposição de cenários possíveis e futuros desejáveis.

Palavras-chave: Infraestrutura Verde; Serviços Ecossistêmicos Urbanos; Eixo Multifuncional; Drenagem Sustentável. 


\begin{abstract}
MARQUES, T.H.N. Multifunctional Axes: Green Infrastructure and Urban Ecosystem Services applied to the Mandaqui stream, São Paulo, SP. Doctoral thesis, Postgraduate Program in Architecture and Urbanism, concentration area Landscape and Environment, University of São Paulo, 2020.

The sanitation and occupation of floodplains were strategic for the city of São Paulo to become the most economically important metropolitan and state capital in the country. Radial and perimeter avenues, capable of supporting the continuous growth of the city towards its peripheries, accompanied the channeling or complete suppression of rivers, streams and green areas of the floodplains, distancing the population and causing different environmental impacts. We assume that valley bottoms are areas of high performance and reflect the opportunity to be converted into Multifunctional Axes capable of structuring a connected network of open spaces, able to catalyze the green and blue within the urban grid while offering a range of ecosystem services. In support of this statement, six principles of Green Infrastructure were defined and integrated into the concept of Ecosystem Services, to be applied to the case study of the Mandaqui stream, São Paulo, SP, simulated from the proposal of possible scenarios and desirable futures.
\end{abstract}

Key words: Green Infrastructure; Urban Ecosystem Services; Multifunctional Axes; Sustainable Drainage. 
SUMÁRIO:

Definição de termos 10

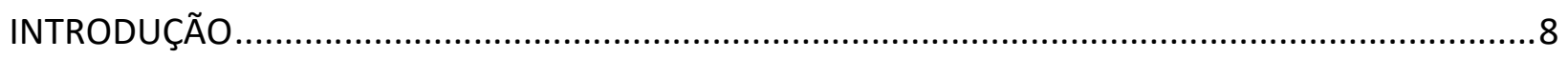

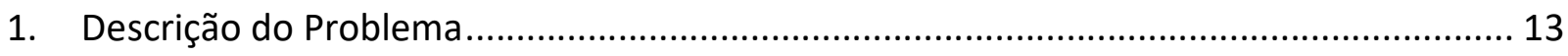

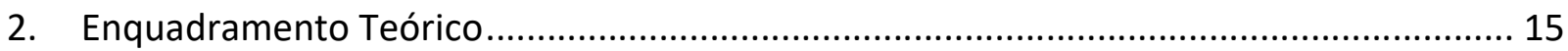

3. Lacunas de conhecimento, hipótese e perguntas norteadoras da tese ......................... 20

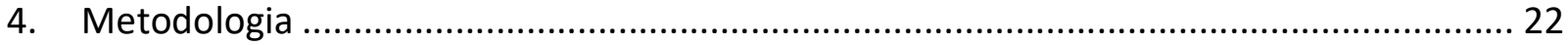

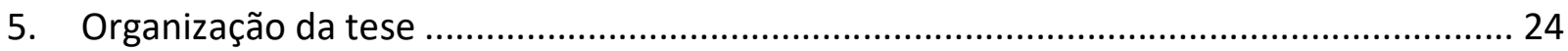

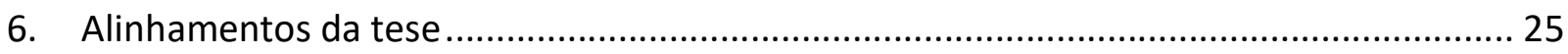

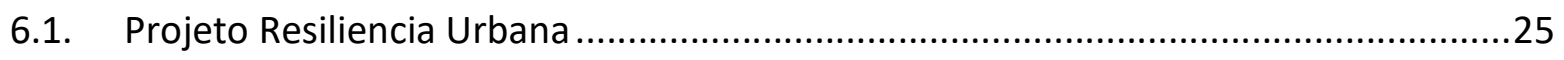

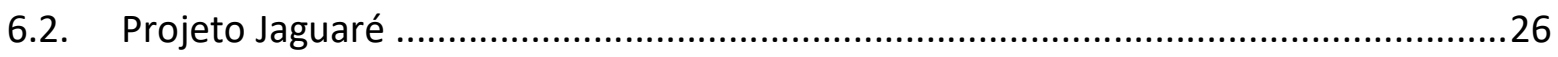

PARTE I - INFRAESTRUTURA VERDE E SERVIÇOS ECOSSISTÊMICOS: CONCEITOS E PRINCÍPIOS

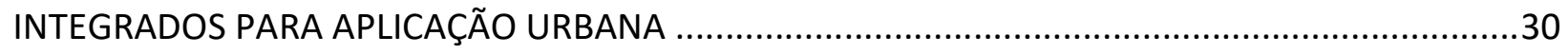

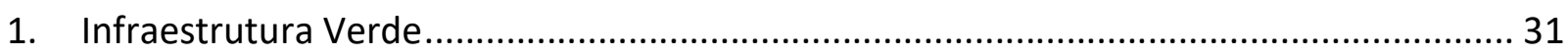

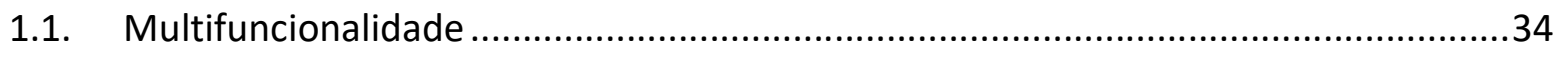

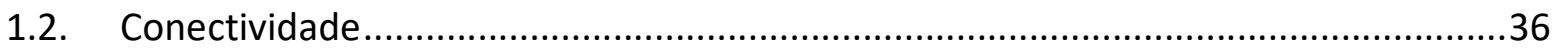

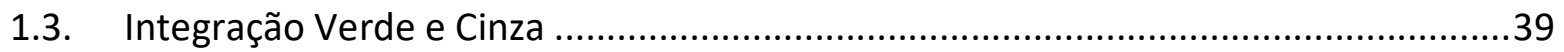

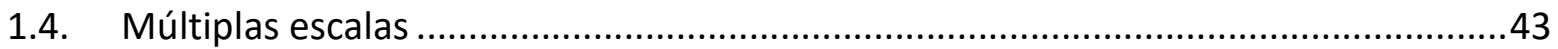

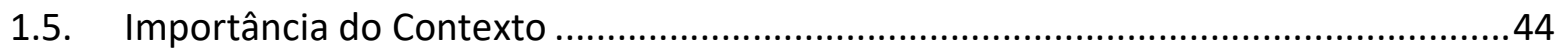

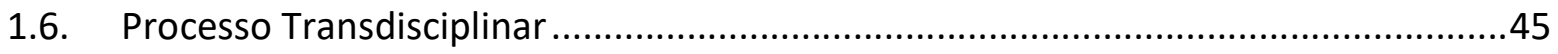

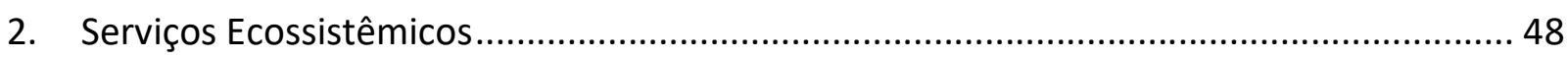

3. Eixos Multifuncionais: A Infraestrutura Verde como provedora de Serviços Ecossistêmicos

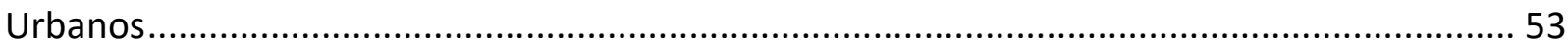

4. Métodos e Critérios para aplicação em estudo de caso .............................................. 58

4.1. Compartimentos da Paisagem, InventÁrio de Espaços Abertos e drenagem ............58

4.2. Inventário de Espaços Abertos e identificação de Serviços Ecossistêmicos urbanos. 60

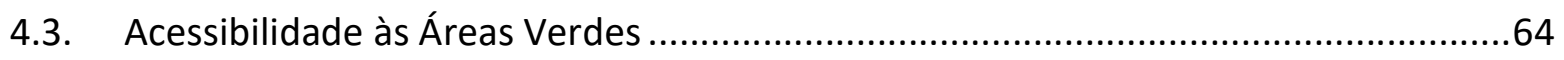

5. Regulação hídrica: escalas de impacto e estratégias LID ............................................6 68

5.1. Aplicação da infraestrutura verde no projeto jaguaré ..............................................70

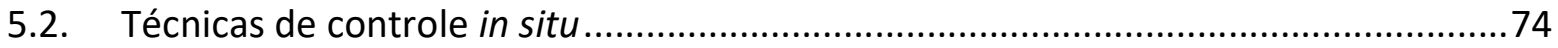


5.3. Uma nova geração de reservatórios ...............................................................78

5.4. Considerações para aplicação no mandaqui.............................................................8

PARTE II- Aplicação ao córrego Mandaqui: integrações para um eixo multifuncional.................82

1. Projeto Resiliência: escolha do eixo em transecto de estudo........................................ 83

2. Conceituação do recorte: bacia e fundo de vale do Mandaqui ....................................... 88

2.1. Planos, ações e legislação com impacto na Bacia do Mandaqui .............................102

3. Compartimentação da Paisagem do Mandaqui .......................................................... 117

3.1. Compartimentos do relevo e estruturas superficiais ...........................................117

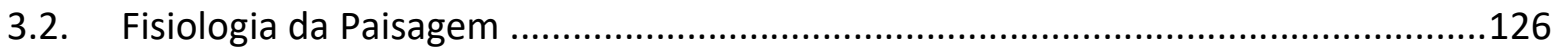

3.3. Distribuição de LIDs e arborização urbana nos Compartimentos da Paisagem .......136

4. Inventário dos espaços abertos e os Serviços ecossistemicos.................................... 142

4.1. Aptidão dos espaços abertos em fornecer serviços ecossistêmicos .......................146

4.2. Sinergias, trade offs e desserviços no fundo de vale ............................................152

4.3. Conectividade e acessibilidade às áreas verdes ................................................159

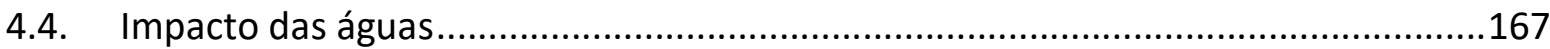

4.5. Considerações parciais: Espaços Abertos e LID .................................................170

5. Cenários Possíveis e Futuros Desejáveis ................................................................... 172

5.1. Cenário e Futuro 1: O Mínimo para o Máximo ......................................................174

5.2. Cenário e Futuro 2: Mantendo os Pés Secos........................................................178

5.3. Cenário e Futuro 3: Reconquista da Várzea .....................................................183

5.4. Considerações parciais- Futuros Desejáveis ......................................................188

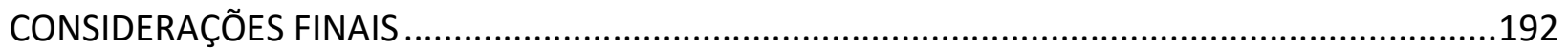

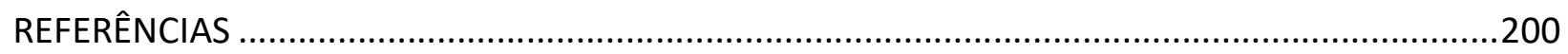

ANEXO 1- Definição de Princípios da Infraestrutura Verde Urbana ........................................213

ANEXO 2- Tabela comparativa para acessibilidae às áreas verdes........................................215 
DEFINIÇÃO DE TERMOS

\title{
Planície Fluvial
}

\begin{abstract}
"É um sistema geomorfológico aplanado, localizado em fundos de vale, que apresenta canais fluviais (únicos ou múltiplos), planícies de inundação e seus sub-compartimentos. Pode ou não apresentar terraços fluviais, diques, lagos, e outras morfologias geradas a partir dos processos geomorfológicos: hidrológicos e sedimentológicos" (RODRIGUES, 2015, p. 328).
\end{abstract}

\section{Fundo de vale}

Áreas mais baixas do relevo, que normalmente acomodam os cursos d'água.

\section{Várzea ou Planície de Inundação}

É o compartimento da planície fluvial que originalmente recebe as inundações mais rotineiras (RODRIGUES, 2015).

\section{Poluição Difusa}

As cargas poluentes difusas são compostas por partículas contaminantes depositadas nas superfícies urbanas (por exemplo, fachadas, pisos, tetos, ruas), sobre a vegetação ou mesmo dispersas no ar. As cargas difusas se originam “(...) com o arraste dos poluentes pelas precipitações e posterior transporte pelo escoamento superficial e, por esta razão, é um fenômeno de natureza aleatória(...)", gerando tanto problemas qualitativos quanto quantitativos para a regulação das águas urbanas (PMSP, 1999, p. 269). Os resíduos sólidos não foram considerados como poluição difusa pela tese, pois não podem ser tratados por estratégias que retomam processos naturais da paisagem e merecem propostas estruturais e não estruturais específicas.

- Propostas estruturais

As propostas estruturais são compostas por dispositivos de drenagem desenhados para desempenhar funções específicas para o manejo das águas urbanas (FCTH, 2017).

○ Propostas não estruturais 
As propostas não estruturais são soluções focadas em aprimorar a gestão integrada das águas urbanas, com destaque à reorganização dos modelos institucionais (FCTH, 2017).

\section{Poluição Pontual}

A poluição pontual é decorrente "(...) de lançamentos de esgotos domésticos não tratados e efluentes industriais". (PMSP, 1999, p. 264)

\section{Biorretenção}

Capacidade de plantas e solos em reter distintos contaminantes carreados pelas águas das chuvas. 


\section{DESCRIÇÃO DO PROBLEMA}

O saneamento e a ocupação das várzeas foram estratégicos para que a cidade de São Paulo se tornasse a capital metropolitana e estatal economicamente mais importante do país. A implantação da ferrovia São Paulo Railway (SPR) no final do século XIX, buscou terrenos disponíveis, baratos e em áreas planas e contínuas da cidade para sua instalação, inaugurando um processo de transformação radical para viabilizar a ocupação das várzeas como espaço habitável (FRANCO, 2005). No entanto, foi a mudança do paradigma de mobilidade de carga e pessoas, inicialmente sobre trilhos e a partir de meados dos anos 20 e 30, sobre pneus, que contribuiu para as intensas e rápidas mudanças ocorridas na cidade durante o século XX.

O Plano de Avenidas de $1930^{1}$, expressou as ambições desenvolvimentistas da capital a partir da proposta de um conjunto de avenidas radiais e perimetrais, capazes de dar suporte ao crescimento continuo da cidade, a partir das áreas centrais em direção às periféricas, onde atualmente se encontram as duas principais unidades de conservação da metrópole paulista, Serra da Cantareira (a norte) e Serra do Mar (a sul), além das áreas de proteção ambiental aos mananciais Billings e Guarapiranga (a sul). A proposta também incluía um conjunto de parques que deveriam dar apoio à vida urbana, mas que não foram priorizados durante a implementação do Plano e tampouco foram incluídos nas normativas que seguiram; ao invés disso houve uma simplificação da proposta, por exemplo pelo Programa de Canalização e Implantação de vias de fundo de vale (Procav, 1987), que deixa claro em seu nome, a que veio.

Atualmente cerca de $20 \%$ dos córregos da cidade são subterrâneos e aproximadamente $5 \%$ daqueles abertos estão confinados em canais de concreto, como parte do sistema de drenagem (MARQUES, 2017b). Os números não parecem tão ruins à primeira vista, porém praticamente todos os córregos subterrâneos ou canalizados se encontram nas áreas urbanizadas, o que torna a cidade completamente árida tanto à presença de água na superfície, e impactada também pela falta das áreas verdes que acompanhavam as várzeas de inundação (ibid). Essa situação, associada às altas taxas de impermeabilização do solo urbano, vem resultando no aumento dos

\footnotetext{
1 "Plano de Avenidas para a Cidade de São Paulo", elaborado pelo engenheiro Francisco Prestes Maia e publicado em 1930.
} 
volumes de chuva escoados superficialmente e no carreamento de cargas difusas aos cursos d’água a jusante.

As previsões relativas às mudanças climáticas apresentadas pelo Painel Intergovernamental para as Mudanças Climáticas, (Intergovernmental Panel on Climate Change - IPCC), indicam como uma de suas consequências a falência das infraestruturas tradicionais (IPCC, 2014). Localmente, se avaliarmos os eventos climáticos da última década, 2010-2020, é perceptível a alternância entre períodos de seca e de chuva intensa, ambos causando impactos sociais, econômicos e políticos expressivos.

Vimos nesse quadro pessimista uma oportunidade de mudança. A necessidade, e urgência, de repensarmos São Paulo a partir de suas várzeas e infraestruturas, transcendendo os modelos deterministas e rígidos a formatos flexíveis que possam se adaptar a fenômenos climáticos, ao mesmo tempo que retomam o fornecimento de serviços ecossistêmicos suprimidos pela urbanização. Posicionamos a problemática das águas não apenas como um problema hidráulico, mas de paisagem, urbano, e que deve priorizar a expansão das áreas verdes e azuis desde as áreas de conservação e preservação até os rincões mais estreitos do tecido urbano ao invés de estender a cidade em direção às suas bordas, estruturando assim, uma rede de Eixos Multifuncionais. 


\section{ENQUADRAMENTO TEÓRICO}

A quebra de paradigmas relacionados ao desenho e planejamento de cidades, regiões e infraestruturas urbanas vem sendo amplamente discutida desde os anos 90, fortemente influenciados pelo então emergente conceito de sustentabilidade. Nesse contexto, a Arquitetura da Paisagem (ou Paisagismo) vem ganhando importância principalmente, mas não exclusivamente, em países da Europa, América do Norte e Ásia. Embora inúmeras abordagens tenham sido desenvolvidas nas últimas três décadas, é possível notar influências de propostas historicamente marcantes por seu arrojo quanto à incorporação de processos e dinâmicas da paisagem no desenho de áreas verdes públicas e à mescla da natureza ao urbano, associados ao planejamento de cidades e territórios.

Frederick Law Olmsted, no final do século XIX, desenha e constrói sistemas de parques urbanos que cumpriam funções ambientais e infraestruturais, além de possibilitar o acesso às áreas verdes por pessoas de distintas realidades socioeconômicas através da trama urbana, exemplificado pelo icônico parque Emerald Necklace em Boston (Figura 1). É a partir de seu trabalho que a disciplina Arquitetura da Paisagem se molda nos E.U.A. Contemporâneo a Olmsted, Ebenezer Howard propõe o desenho da Cidade Jardim², indicando que deveríamos morar num lugar onde os melhores aspectos da cidade industrial inglesa, (por exemplo: emprego e transporte) estivessem em sinergia às melhores características da vida no campo, (por exemplo: casas amplas, áreas verdes e ar puro). Ian McHarg (1969), nos anos 60, diante de cidades norte americanas cada vez mais consolidadas, propõe a utilização da natureza como ferramenta de desenho e planejamento regional. Influenciado pela ecologia e pela geografia McHarg propõe o entendimento do território a partir de distintas camadas que, sobrepostas, fornecem a base para o desenvolvimento de planos mais holísticos em larga escala.

\footnotetext{
${ }^{2}$ Publicado originalmente como Cities of Tomorrow em 1902.
} 
Figura 1: Sistema de Parques- Emerald Necklace em Boston, E.U.A.

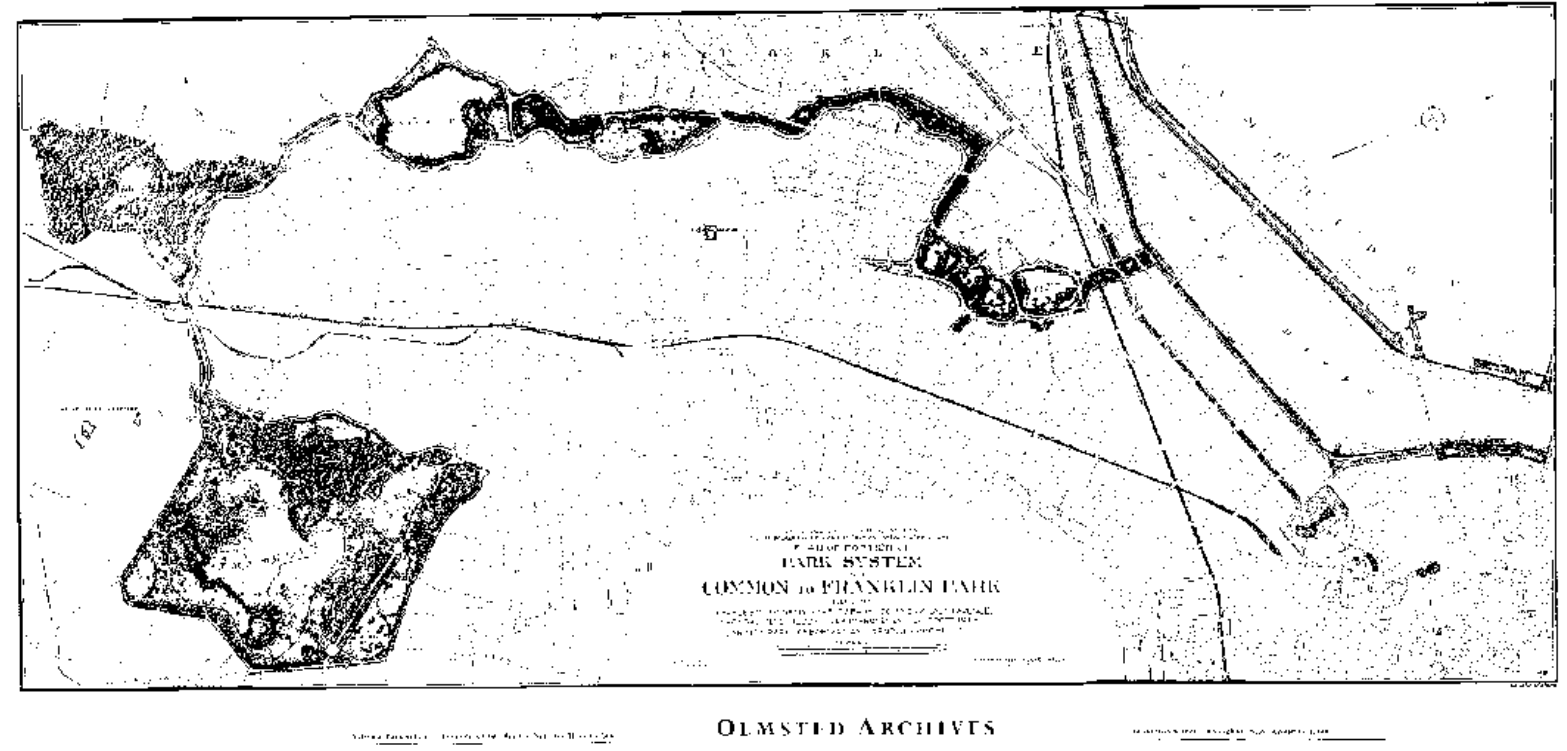

Fonte: Olmsted Archives.

A disciplina de Arquitetura da Paisagem possui um caráter multidisciplinar e de espectro amplo de atuação (ASLA, 2017), com vertentes desde as artes plásticas e relacionadas ao planejamento da paisagem, a partir da abordagem da natureza e do território quanto à conservação e a biodiversidade (CHIESA; MAGNOLI, 2008). O planejamento da paisagem, em suas distintas escalas, vem ao longo do tempo sendo alimentando por discussões que relacionam as dimensões ambiental e cultural (PELLEGRINO, 2017a). A paisagem, tradicionalmente considerada em oposição à cidade, assim como natureza à cultura, passa a associar a cidade à paisagem e a considerar a natureza como agente cultural. Aplicado ao meio urbano, Waldheim afirma que a “(...) Arquitetura da Paisagem vem se tornando uma lente através da qual a cidade contemporânea é representada e um meio pelo qual é construída" (tradução nossa, 2006, p. 15), compreendendo o urbano como um sistema dinâmico composto por construções e meio natural, desenhados e erguidos de forma interdependente e interconectada (LABOY, 2016).

A incursão de termos ecológicos e biológicos, como ecossistema e metabolismo, passaram a ser associados à sustentabilidade urbana principalmente durante a década de 90 (NEWMAN, 1999). É a partir do enfoque ecológico que a cidade passa a ser definida como parte integral do meio ambiente (FRANCO, 2003), considerada, ela mesma, um ecossistema (NEWMAN, 1999). A 
paisagem, como forma, é resultado dos processos ecossistêmicos, que operam de modo interconectado e interdependente e são o suporte da biosfera (HOUGH, 1995). A cidade como parte integral do ecossistema e não entidade isolada $(\mathrm{KOH}, 2011)$, deverá ser o resultado desses mesmos processos, relacionados em distintas escalas do território (HOUGH, 1995). Esse posicionamento traz uma proposta de mudança de paradigma, essencial para que os impactos ambientais gerados pela vida urbana possam ser avaliados e planejados e o urbano seja considerado parte irrestrito da paisagem.

Não é à toa que a partir das últimas décadas do século XX haja uma certa fricção terminológica entre paisagem, ecologia e urbanismo dando origem a conceitos como, Paisagismo Urbanístico (WALDHEIM, 2006), Urbanismo Ecológico (MOSTAFAVI; DOHERTY, 2014) e Paisagismo Ecológico (FORMAN; GODRON, 1986), tendo o último se tornado uma disciplina específica. A aplicação e teste desses termos, carregados conceitualmente, às vezes parte de situações idealizadas em modelos tabula rasa, onde o desenho e planejamento urbanos são iniciados em terrenos livres de intervenções e testados para serem replicados. Porém, são as grandes aglomerações humanas consolidadas ao redor do mundo aquelas que possuem os maiores problemas ambientais atualmente (HAGAN, 2014), necessitando planejamento, desenho e gestão. Visionar as cidades consolidadas como parte integral dos ecossistemas pressupõe compreender três interações básicas: a implicância da urbanização na modificação do ambiente; a influência da forma, funções e crescimento da cidade pelo ambiente; e a retroalimentação contínua na cidade, entre seres humanos, cultura e ambiente físico (VALASKI, 2013).

A cidade como ecossistema idealiza também que seja possível pensarmos a Paisagem como Infraestrutura (BÉLANGER, 2012). Esse aporte terminológico avalia o papel e a degradação das infraestruturas tradicionalmente desenhadas, rígidas ou cinzas, em contraponto à potencial retomada dos processos, dinâmicas e sistemas de paisagem. De modo geral, o termo infraestrutura se refere a qualquer recurso construído pelo homem que forneça serviços e bens essenciais para a manutenção da vida em sociedade (DA SILVA; WHELLER, 2017), portanto, são associados a um certo sentido de estabilidade da vida em comunidade (EDWARDS, 2002). Essa função de suporte estabeleceu, ao longo de um processo cada vez mais complexo e sofisticado de assentamento humano, uma relação onde a natureza se tornou o recurso para satisfazer as 
necessidades humanas (EDWARDS, 2002), não mais o meio onde estas relações pudessem ocorrer.

As infraestruturas vêm acompanhando o processo de discussão e transição a cidades como ecossistema. De modo geral, ao assumir uma postura mais integrada à paisagem e ao ambiente, as infraestruturas surgem como oportunidades de flexibilização de sistemas rígidos, monofuncionais e centralizados a redes multifuncionais e resilientes que, ao permearem o tecido urbano em suas distintas escalas, poderão contribuir para a melhora do ciclo da água, para a regulação do microclima e do metabolismo das cidades (CORMIER; PELLEGRINO, 2008), beneficiando a saúde e o bem-estar das pessoas enquanto enriquecem a fauna e a flora e fortalecem ou estabelecem conexões ecossistêmicas. O foco não se pauta apenas nas possibilidades de evitar ou minimizar impactos relacionados ao desenvolvimento das infraestruturas, mas sim, de explorar as possibilidades de inovação que poderão contribuir para cidades mais sustentáveis (AHERN, 2007). Essa nova ou requalificada rede de infraestruturas tem caráter integrador entre seus aspectos verdes, azuis e cinzas ou naturais e artificiais e é capaz de catalisar o fornecimento de distintos serviços ecossistêmicos à cidade.

Atualmente as denominações que mesclam as palavras infraestrutura, verde, azul, ecológico e natural são diversas, sem que haja um consenso em sua definição ou aceitação (DA SILVA; WHELLER, 2017). Ahern (1995), focado no planejamento de Corredores Verdes nos E.U.A. apresentou uma longa lista relacionando distintos termos ao local onde eram utilizados (Europa e/ou América do Norte), sua escala de impacto e as principais funções que pretendiam cumprir (abióticas, bióticas e culturais) $^{3}$. Onze anos depois Davies et al. (2006) apresentam uma lista ainda mais ampla, ao se referir à abundância de conceitos verdes existentes naquele momento e aos distintos benefícios associados a eles. Alguns destes termos vêm sendo utilizados no Brasil, tanto para a conservação e preservação ambiental em larga escala, quanto para a reconexão de fragmentos verdes, espaços livres e qualificação de áreas ribeirinhas urbanas. A discussão terminológica parece inesgotável. Nossa intensão é fornecer um panorama da aplicação dos

\footnotetext{
${ }^{3}$ A lista completa pode ser encontrada em: AHERN, J. Greenways as a Planning Strategy. Landscape and Urban Planning Journal, 33:1-3, p.131-155, 1995.
} 
termos mais utilizados no país a partir de projetos de referência e com a identificação das escalas abordadas, como forma de contextualizar e delimitar os conceitos utilizados na pesquisa (Quadro 1).

Quadro 1:Termos mais utilizados no Brasil.

\begin{tabular}{|l|c|c|c|l|}
\hline \multicolumn{1}{|c|}{ Termo } & $\begin{array}{c}\text { Escala (N= } \\
\text { Nacional; } \\
\text { R=Regional; } \\
\text { U= Urbana) }\end{array}$ & $\begin{array}{c}\text { Em } \\
\text { Instrumento } \\
\text { s legais }\end{array}$ & $\begin{array}{c}\text { Aporte } \\
\text { teórico- } \\
\text { projetual }\end{array}$ & \multicolumn{1}{|c|}{ Referência } \\
\hline Cinturões Verdes & $\mathrm{R}$ & $\mathrm{x}$ & $\mathrm{x}$ & $\begin{array}{l}\text { Reserva da Biosfera da Mata Atlântica: } \\
\text { IF in SMA, 2019; RBMA in SMA, 2008 }\end{array}$ \\
\hline $\begin{array}{l}\text { Corredores } \\
\text { Ecológicos ou de } \\
\text { Biodiversidade }\end{array}$ & $\mathrm{N} / \mathrm{R}$ & $\mathrm{x}$ & $\mathrm{x}$ & $\begin{array}{l}\text { 2002- 2006 e 2006-2015, MMA, 2015; } \\
\text { Programa Nacional de Conectividade } \\
\text { de Paisagens: CONECTA, MMA, 2018 }\end{array}$ \\
\hline Corredores Verdes & $\mathrm{U}$ & $\mathrm{x}$ & $\mathrm{x}$ & $\begin{array}{l}\text { Prefeitura Municipal do Rio de Janeiro- } \\
\text { SMAC, 2011; HERZOG, 2004 }\end{array}$ \\
\hline $\begin{array}{l}\text { Caminhos Verdes ou } \\
\text { Parques Lineares }\end{array}$ & $\mathrm{U}$ & $\mathrm{x}$ & $\mathrm{x}$ & $\begin{array}{l}\text { Prefeitura Municipal de São Paulo- PRE } \\
\text { 2002; 2016 }\end{array}$ \\
\hline Infraestrutura Verde & $\mathrm{R} / \mathrm{U}$ & - & $\mathrm{x}$ & $\begin{array}{l}\text { Considera os termos anteriores como } \\
\text { elementos da Infraestrutura Verde. Ex.: } \\
\text { PELLEGRINO; MOURA (org.), 2017 }\end{array}$ \\
\hline $\begin{array}{l}\text { Infraestrutura Natural } \\
\text { Infraestrutura Verde- }\end{array}$ & $\mathrm{R}$ & $\mathrm{x}$ & $\mathrm{x}$ & $\begin{array}{l}\text { Foco na regulação hídrica. Ex.: WRI, } \\
\text { 2018 }\end{array}$ \\
\hline $\begin{array}{l}\text { Azul ou trama verde- } \\
\text { azul }\end{array}$ & $\mathrm{U}$ & $\mathrm{x}$ & $\begin{array}{l}\text { Pode ser utilizada como sinônimo de } \\
\text { Infraestrutura Verde. Ex.:FCTH, 2017 }\end{array}$ \\
\hline
\end{tabular}

Fonte: elaborado pela autora a partir de pesquisa bibliográfica.

Criticados, aplicados e em alguns casos amplamente discutidos (ex.: DAVIES et al., 2006), os termos apresentados são influenciados por contextos e problemas específicos de cada país ou região, relacionados ao uso do solo, a valores culturais e aos sistemas legislativos e de planejamento (AHERN, 1995). A escolha da Infraestrutura Verde, como um dos conceitos norteadores da tese, se baseia no crescente uso e interesse associado a seu planejamento e projeto no Brasil (FRANCO, 2010), tendo aderência às linhas de investigação do Labverde, onde a pesquisa doutoral foi desenvolvida, além do acesso a uma grande quantidade de publicações e casos aplicados, tanto internacional quanto nacionalmente. Entende-se que o termo não é 
estanque e tampouco pretende ser, refletindo dessa forma a própria dinâmica científica (ver Parte I - Capítulo 1-).

\section{LACUNAS DE CONHECIMENTO, HIPÓTESE E PERGUNTAS NORTEADORAS DA TESE}

A tese tem por objetivo colaborar para a geração de conhecimento focado na quebra de paradigma dos métodos de engenharia e planejamento urbano tradicionais, os quais vêm tratando os fundos de vale prioritariamente como áreas problemáticas da cidade. Nos baseamos nos conceitos de Infraestrutura Verde e Serviços Ecossistêmicos e partimos da hipótese:

Os fundos de vale são áreas de alto desempenho ambiental e refletem a oportunidade de serem convertidos em Eixos Multifuncionais, capazes de estruturar uma rede conectada de espaços abertos, catalisadora do verde e do azul no interior da trama urbana oferecendo diversos Serviços Ecossistêmicos.

Embora a pesquisa relacionando as distintas tipologias de Infraestrutura Verde ao fornecimento de Serviços Ecossistêmicos venha sendo ampliada nos últimos anos, ainda existem diversas lacunas a serem pesquisadas. Há uma falta de estudos que avaliam os múltiplos serviços prestados pela mesma infraestrutura, suas sinergias, trade-offs e desserviços ${ }^{4}$ (HAASE et. al, 2014), principalmente na escala urbana e sobretudo nas escalas do bairro e do sítio específico, onde também faltam definições mais precisas a respeito dos Serviços Ecossistêmicos prestados e seus benefícios (BURKHARD et. al, 2012; HAASE et. al, 2014). No Brasil, estudos relacionam sustentabilidade, resiliência urbana e a aplicação da Infraestrutura Verde ${ }^{5}$ em distintas escalas, citando em alguns casos o fornecimento dos Serviços Ecossistêmicos. No entanto faltam pesquisas que aportem a integração conceitual entre os dois termos e qual a relevância de um para o outro, principalmente para aplicação na escala urbana. Também faltam análises que considerem as possíveis sinergias, trade-offs e desserviços existentes nos distintos níveis de integração entre as Infraestruturas Verde e cinza e como seria possível potencializar as sinergias

\footnotetext{
${ }^{4}$ ver Parte I - Capítulo 2.

${ }^{5}$ Destacam-se os estudos elaborados no Labverde- FAU-USP, publicados em revista periódica e livros. Para maiores informações visitar < https://www.revistas.usp.br/revistalabverde> .
} 
e minimizar os trade-offs e desserviços ecossistêmicos. Dessa forma, a tese delimita duas lacunas centrais a serem atendidas:

1. Aportar a integração conceitual entre Infraestrutura Verde (IEV) e Serviços Ecossistêmicos (SE) e sua relevância para aplicação na escala urbana.

2. Analisar possíveis sinergias, trade-offs e desserviços existentes na integração entre as Infraestruturas Verde e cinza e como seria possível potencializar as sinergias e minimizar os trade-offs e desserviços ecossistêmicos.

Para atender à hipótese, a partir da consideração das lacunas de conhecimento apresentadas, foram elaboradas cinco perguntas norteadoras da tese, definidas a partir de objetivos específicos, a serem respondidas durante as partes e capítulos nos quais se organiza o trabalho. Conforme segue:

a) Como os princípios de Infraestrutura Verde e os Serviços Ecossistêmicos podem ser associados para dar suporte ao desenho de Eixos Multifuncionais?

b) Qual a potencial integração da Infraestrutura Verde para a regulação hídrica nos distintos compartimentos da paisagem?

c) Qual a aptidão e os possíveis desserviços associados aos Espaços Abertos da bacia?

d) Quais as sinergias, trade-offs e desserviços relacionados às Infraestruturas Verde e cinzas no fundo de vale?

e) Como é possível enfatizar as sinergias e reduzir os trade-offs e desserviços entre as infraestruturas no fundo de vale? 


\section{METODOLOGIA}

Embora a disciplina Arquitetura da Paisagem não tenha atingido sua autonomia no Brasil, (é uma atribuição dos arquitetos urbanistas), a pesquisa na área da Paisagem vem crescendo, acompanhando tendências mundiais (inclusive no nosso país), como alternativa aos governos para o planejamento sustentável frente às mudanças climáticas e à expansão urbana (MORAES VICTOR et. al., 2004; SCHÄFFLER; SWILLING, 2012 apud MELL, I.C., 2017, p. 136) ${ }^{6}$. Seu caráter transdisciplinar também influencia a consolidação da Arquitetura da Paisagem como um campo específico de pesquisa (LE:NOTRE, 2008). Nesse sentido, o Conselho Europeu de Escolas de Arquitetura da Paisagem (ECLA, acrônimo do original em inglês), define três grupos principais de abordagens normalmente aplicadas à pesquisa de projeto ou planejamento da Paisagem, como forma de contribuir para o desenvolvimento de uma linha de pesquisa comum às atividades de doutoramento nessa área de estudo:

a) Pesquisa sobre / de planejamento e desenho (Research about/of): tem o objetivo de melhorar teorias e métodos da arquitetura da paisagem (por exemplo, processos de planejamento e desenho), tirando conclusões de estudos de caso, análise de projetos, planos de paisagens etc.;

b) Pesquisa através/ a partir do planejamento e desenho (Research through/by): análise de estratégias espaciais complexas produzindo, aplicando e avaliando cenários; elabora, aplica e avalia novas tipologias baseadas nas necessidades (do público), a fim de encontrar soluções para um problema social ou espacial, elaborando e avaliando várias propostas, cenários, etc.;

c) Pesquisa para (suporte)/do planejamento e desenho (Research for/supporting): pesquisa incluindo ciências sociais, ecologia ou outras disciplinas aplicadas ao planejamento e

\footnotetext{
${ }^{6}$ MORAES VICTOR, R. A. B. et al. Application of the biosphere reserve concept to urban areas: The case of Sao Paulo City Green Belt Biosphere Reserve, Brazil-Sao Paulo Forest Institute: A case study for UNESCO. Annals of the New York Academy of Sciences, 1023, p. 237-281, 2004.
}

SCHÄFFLER, A. e SWILLING, M. Valuing green infrastructure in an urban environment under pressure-The Johannesburg case. Ecological Economics, 86, p. 246-257, 2012. 
projeto. Por exemplo a partir da classificação da paisagem, levantamento das necessidades do público, percepção dos valores pelas pessoas etc.

Essa caracterização não é fixa, mas oferece uma base sobre a qual é possível definir os processos metodológicos e ferramentas que serão utilizados durante a pesquisa, muitos deles advindos de disciplinas afins à arquitetura da paisagem. Na tese as três abordagens serão utilizadas, permeadas por métodos quantitativos e qualitativos combinados ou associados como forma de fortalecer o estudo desenvolvido (CRESWELL, 2009). O trabalho se divide em Parte I, Parte II, além da Introdução e Considerações Finais.

A Parte I contará com revisão bibliográfica a respeito dos termos Infraestrutura Verde e Serviços Ecossistêmicos com o objetivo de identificar os princípios de Infraestrutura Verde e propor como os dois conceitos poderão estar relacionados para aplicação urbana. A pesquisa para suporte será realizada com o intuito de definir métodos complementares e critérios para a classificação da paisagem e dos Espaços Abertos e para a análise da aptidão desses espaços em fornecer distintos Serviços Ecossistêmicos.

A Parte II irá relacionar as três abordagens, sobre, através e para suporte, ao aplicar os princípios, métodos e critérios definidos na Parte l ao estudo de caso do córrego Mandaqui. Três cenários exploratórios (cenários possíveis) são desenhados a partir de distintos agentes de mudança e convertidos em cenários normativos, possibilitando a visualização de Futuros Desejáveis (ver Parte II- Capítulo 5), comparáveis quanto a um critério específico, com o objetivo de dar suporte a tomada de decisão (CRESWELL, 2009). Vale ressaltar que os materiais e métodos aqui dispostos não estão fechados ou finalizados, mas sim abertos para a emersão de alternativas que possam ser necessárias para o bom andamento da pesquisa (ibid). 


\section{ORGANIZAÇÃO DA TESE}

A tese se organiza em quatro partes sendo: Introdução, Parte I, Parte II e Considerações Finais. A Introdução apresentou o problema, o enquadramento teórico, a hipótese, as lacunas de conhecimento, as perguntas norteadoras da tese e a metodologia utilizada. As Partes I e II e as Considerações Finais se prestarão a responder às perguntas norteadoras, conforme segue:

PARTE I: Infraestrutura Verde e Serviços Ecossistêmicos: conceitos e princípios integrados para aplicação urbana.

a) Como os princípios de Infraestrutura Verde e os Serviços Ecossistêmicos podem ser associados para dar suporte ao desenho de Eixos Multifuncionais?

PARTE II: Aplicação no Mandaqui: integrações para um eixo multifuncional.

b) Qual a potencial integração da Infraestrutura Verde para a Regulação Hídrica nos distintos compartimentos da paisagem? (Capítulo 3)

c) Qual a aptidão e os possíveis desserviços associados aos Espaços Abertos da bacia? (Capítulo 4)

d) Quais as sinergias, trade-offs e desserviços relacionados às Infraestruturas Verde e cinzas? (Capítulo 4)

e) Como é possível enfatizar as sinergias e reduzir os trade-offs e desserviços entre as infraestruturas no fundo de vale? (Capítulo 5)

Considerações Finais

As Considerações finais irão acessar a hipótese e as lacunas da pesquisa a partir da discussão das perguntas relacionadas às Partes I e II. 


\section{ALINHAMENTOS DA TESE}

A presente tese está vinculada a dois projetos de pesquisa realizados entre 2015 e 2017. O Projeto Resiliência Urbana possui caráter conceitual, analítico e propositivo teórico quanto ao papel da Infraestrutura Verde na amortização dos efeitos das mudanças climáticas em São Paulo. O Projeto Jaguaré foca na aplicação de técnicas de Infraestrutura Verde dedicadas ao manejo ecológico das águas de chuva. Cada um dos projetos será descrito brevemente a seguir, e citado ao longo da tese. A contribuição da doutoranda a cada um deles também é apresentada.

\subsection{PROJETO RESILIENCIA URBANA}

O projeto “Infraestrutura Verde para a Resiliência Urbana às Mudanças Climáticas da cidade de São Paulo", ou Projeto Resiliência Urbana, aprovado pela FAPESP n. 2015/10597-0 e coordenado pela Profa. Dra. Maria Assunção Ribeiro Franco, Labverde, FAU-USP, uniu um grupo multidisciplinar de especialistas focados em “(...) desenvolver critérios de avaliação da influência do verde urbano na mitigação climática e indicar diretrizes para o desenho estratégico da Infraestrutura Verde (...)"(FRANCO, 2019, p. 16). Foram definidas três frentes de trabalho dedicadas a aspectos do microclima, manejo das águas e geofísicos urbanos. O Projeto delimitou uma área de estudo retangular de $20 \mathrm{~km}$ de extensão por $5 \mathrm{Km}$ de largura, denominada transecto de estudo, que comprime áreas da Serra da Cantareira, do vale do rio Tietê, da cumeeira da av. Paulista e do vale do rio Pinheiros (Figura 2).

A aderência do projeto de pesquisa doutoral ao Projeto Resiliência Urbana está sobretudo, mas não exclusivamente, vinculada à escolha da área de estudo, definida como o fundo de vale do Mandaqui e sua a bacia hidrográfica, plenamente incorporados no Transecto (MARQUES, 2017b). A doutoranda colaborou com as discussões conceituais vinculando a Infraestrutura Verde aos Serviços Ecossistêmicos. Ao longo dos 04 anos de desenvolvimento da tese, foram publicados estudos complementares abordando diferentes escalas (transecto, bacia, eixo, local específico), não cronologicamente organizados, que ao discutir conceitos e testar métodos de análise e percepção da Infraestrutura Verde confluíram para a elaboração do arcabouço conceitual e metodológico apresentado neste trabalho. Tais trabalhos serão citados durante a tese. A 
cooperação com profissionais de outras áreas também influenciou a definição e escolha de métodos para a análise da paisagem (SCHUTZER, 2012; ver Parte I - Subcapítulo 4.1) e forneceu perspectivas complementares à incursão da Infraestrutura Verde na cidade de São Paulo (por exemplo LOCATELLI et al., 2017).

Figura 2: Localização do Transecto e área de estudo da tese.

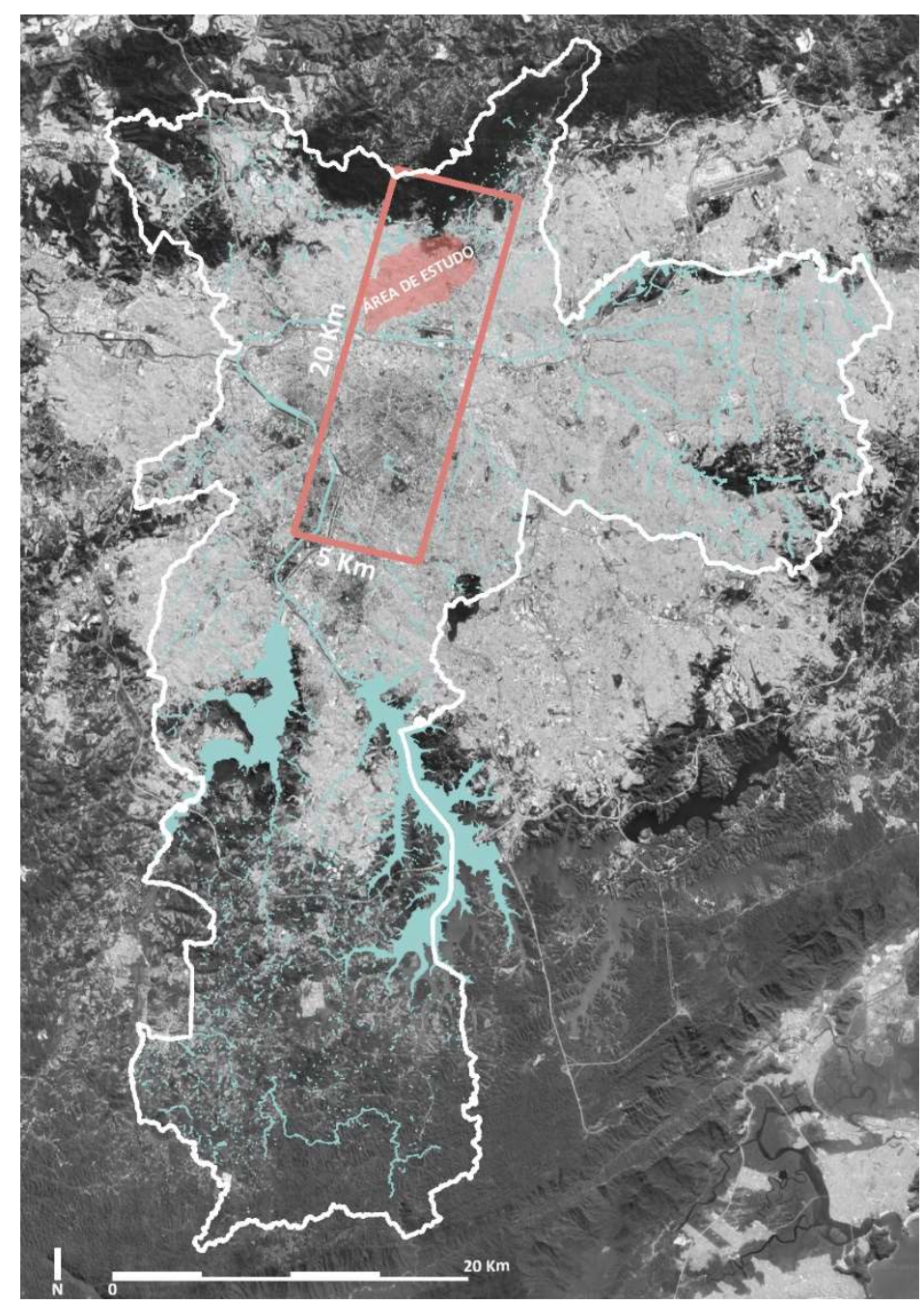

Fonte: elaborado pela autora sobre base de foto satélite obtida por GoogleEarth.

\subsection{PROJETO JAGUARÉ}

O Projeto “Desenvolvimento de Metodologia e Projeto-Piloto de Revitalização de Bacia Urbana, Replicável para as demais Bacias da Região Metropolitana (Bacia do Córrego do Jaguaré) - Empreendimento 2014 At-653", ou Projeto Jaguaré foi articulado pela Associação Águas Claras 
do Rio Pinheiros, coordenado pela Fundação Centro Tecnológico de Hidráulica (FCTH) e financiado pelo Fundo Estadual de Recursos Hídricos (FEHIDRO).

Foi reunida uma equipe interdisciplinar que aproximou as áreas de engenharia, arquitetura da paisagem e urbanismo durante um processo não linear e interdependente de estudo e proposição de Infraestrutura Verde, focada na drenagem das águas de chuva para a bacia piloto do córrego Jaguaré. A Bacia representa $1 / 10$ da área da Bacia do rio Pinheiros, cerca de 27 km², está localizada completamente dentro do setor oeste da cidade de São Paulo (Figura 3) e é caracterizada por diversos usos de solos, representativos de outras bacias hidrográficas da região metropolitana de São Paulo (FCTH, 2017).

Figura 3: Localização da Bacia do córrego Jaguaré em relação aos limites da cidade de São Paulo

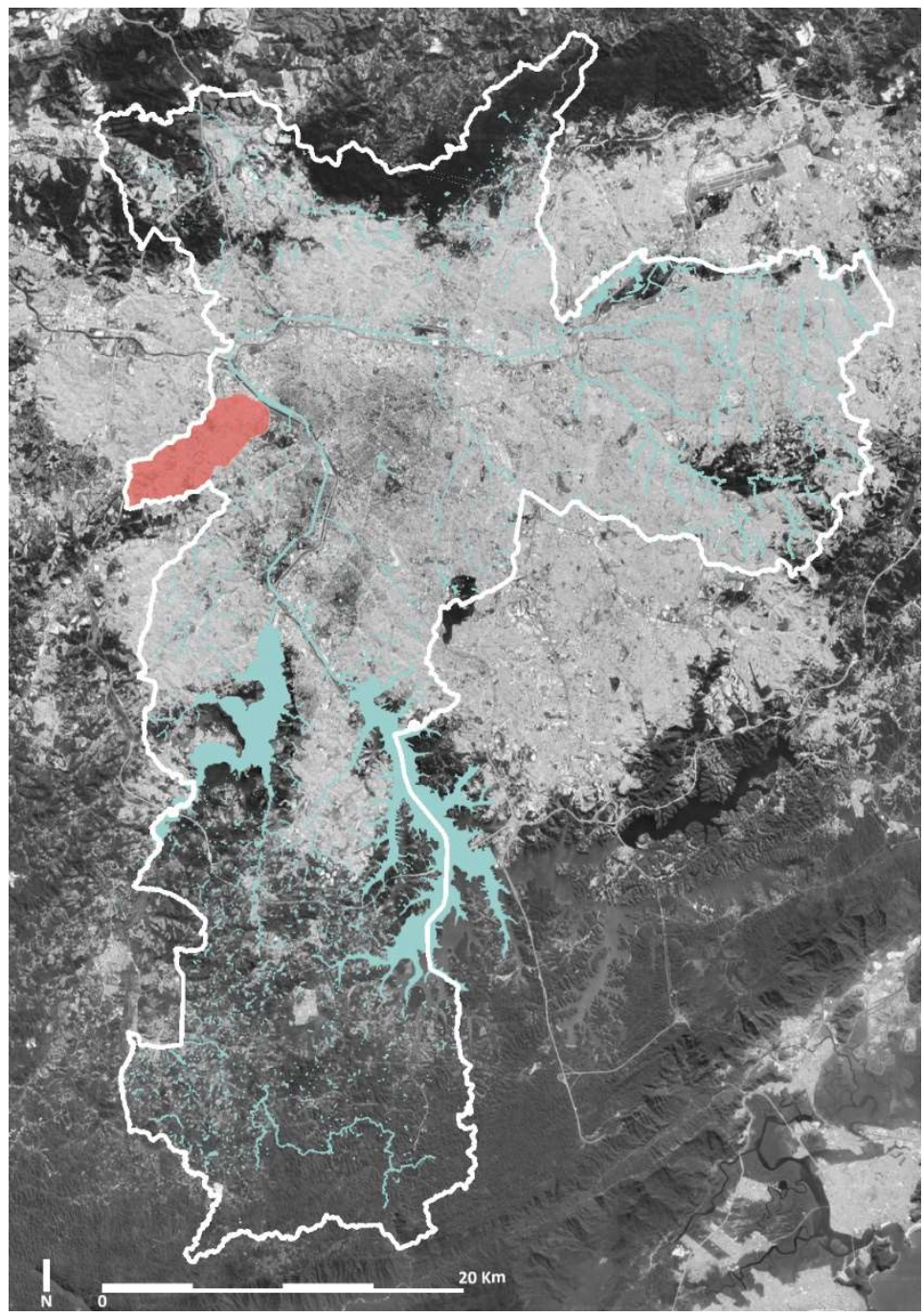

Fonte: elaborado pela autora sobre base de foto satélite obtida por GoogleEarth. 
A partir do estudo de dispositivos de drenagem de baixo impacto (LID)7, foram propostas medidas estruturais de micro e macro drenagem. A dispersão de LIDs pela bacia hidrográfica, como elementos de controle in situ do escoamento superficial, tem a finalidade de deter pequenos volumes de água e sobretudo, remover parte das cargas poluentes difusas carreadas pelas primeiras chuvas (first flush), a partir de processos de biorretenção. Já os LIDs de grandes dimensões, como as bacias de detenção e retenção, ocuparam espaços abertos residuais, áreas ao longo dos córregos e áreas a serem desapropriadas com o objetivo de amortecer os volumes de água esperados para chuvas de intensidade de até TR 100 anos. Durante o desenvolvimento da pesquisa houve a necessidade de abordar a questão dos resíduos sólidos, identificado como um dos grandes problemas quanto ao funcionamento das infraestruturas de drenagem tradicionais ou verdes, assim como as águas residuais domésticas e industriais, atualmente as grandes responsáveis pela contaminação das águas da bacia. Sendo assim, identificam-se quatro objetivos específicos do Projeto:

- Amortecer o impacto das águas de chuva de intensidade TR 100 anos;

- Propor ações não estruturais para o manejo dos resíduos sólidos na bacia;

- Remover os maiores volumes possíveis de poluição difusa;

- Reduzir a Demanda Biológica por Oxigênio (DBO) nos córregos para níveis estipulados pela Classe 3, conforme dispostos no resolução 537/2005 do CONAMA ${ }^{8}$.

Os procedimentos da pesquisa envolveram medições em campo, análises laboratoriais (qualidade das águas), simulações e modelagens em PCSWMM (modelos hidráulicos), espacialização georreferenciada de dados em ArqMap- GIS, simulações de desenhos em AutoCAD (uso e ocupação do solo, desenho de tecnologias e simulação da ocupação dos Espaços Abertos pelos LIDs) e modelos paramétricos Grasshoper (nova geração de reservatórios), incorporados a um processo de trabalho não linear que manteve uma visão holística da drenagem urbana ao longo do projeto (RIZZI et al., 2017).

\footnotetext{
${ }^{7}$ Tradução da equipe do Projeto a partir de Low Impact Development, LID; (UACDC, 2010).

${ }^{8}$ Classe 3: águas que podem ser destinadas: a) ao abastecimento para consumo humano, após tratamento convencional ou avançado; b) a irrigação de culturas arbóreas, cerealíferas e forrageiras; c) a pesca amadora; d) a recreação de contato secundário e; d) a dessedentarão de animais (para saber mais, consultar: CONAMA, RESOLUÇÃO No 357, DE 17 DE MARÇO DE 2005, Publicada no DOU no 053, de 18/03/2005, págs. 58-63)
} 
Como resultado, foram apresentados três cenários exploratórios, sendo: Cenário Crítico, Cenário Planejamento Governamental e Cenário de Revitalização. O Cenário Crítico considerou que nenhum dos planos governamentais seria implementado e não haveria planos futuros relacionados ao manejo das águas na bacia. O Cenário Planejamento Ambiental considerou que todos os Planos e Ações governamentais existentes seriam implementados. Já o Cenário de Revitalização considerou que além da implementação dos planos e ações existentes seriam atendidas as demandas analisadas pelo Projeto Jaguaré a partir das medidas estruturais e não estruturais de Infraestrutura Verde (azul) propostas num horizonte de ação até o ano de 2040.

A doutoranda colaborou com o projeto na identificação e caracterização dos usos e ocupação do solo e Espaços Abertos da bacia além do impacto das legislações que regem o zoneamento do solo e a provisão de habitação social. Pesquisou, simulou graficamente e desenhou quais seriam os dispositivos de baixo impacto que melhor poderiam se adaptar ao contexto da bacia e a cada tipo de Espaço Aberto e qual a porcentagem desses espaços poderia ser ocupado por tais dispositivos. Também adicionou discussões ao redor da possibilidade de instalação de Parques Lineares Multifuncionais (MARQUES, et al., 2017). Tais informações estão disponíveis em artigos, capítulos de livro, resumos apresentados em eventos científicos e uma completa publicação organizada em oito volumes distribuídos em três tomos, (FCTH, 2017), citados ao longo da tese (ver especialmente Parte I- Capítulo 5). 


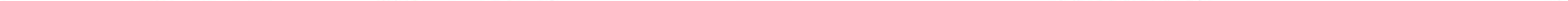




\section{INFRAESTRUTURA VERDE}

O termo de Infraestrutura Verde (IEV) começa a ser utilizado no final dos anos 90 do século XX nos E.U.A. A definição que se tornou amplamente conhecida, a partir da influência de Benedict e McMahon, considera a IEV como uma “(...) rede interconectada de espaços verdes que conserva os valores e funções dos ecossistemas naturais associados aos benefícios para os seres humanos" (BENEDICT; MCMAHON, 2002, p. 05, tradução nossa). Ao mesmo tempo, os autores compreendem que a IEV pode ter “(...) significados diferentes para pessoas diferentes, dependendo do contexto no qual é utilizado" (ibid). Embora atualmente mais consolidado ${ }^{9}$, o termo Infraestrutura Verde ainda carrega um certo dinamismo conceitual que repercute na falta de limites em sua definição, atrelado também à amplitude de escalas na qual é aplicado, desde a escala local urbana até o planejamento de redes ecossistêmicas de caráter regional e nacional (HANSE; PAULEIT, 2014). Distintos trabalhos vêm discutindo exaustivamente o conceito e seus e limites terminológicos (ex.: DAVIES et al., 2006; MELL, 2017). O objetivo desse capítulo é identificar e definir quais os princípios com maior relevância para a aplicação da IEV em áreas urbanas e como tais princípios podem criar sinergias entre a Infraestruturas Verde e as demais redes de sistemas localizadas nos fundos de vale urbanizados, fomentando a criação de Eixos Multifuncionais. Será feito, portanto, um afunilamento quanto ao uso e aplicação do termo, partindo da escala do planejamento urbano e em direção à escala do sítio específico.

Se inicialmente a IEV estava associada a movimentos conservacionistas de atuação em escalas regionais, (BENEDICT; MCMAHON, 2006; DAVIES et al., 2006), a necessidade latente de melhorar a qualidade ambiental das nossas cidades, cada vez mais saturadas, degradadas e dependentes dos recursos naturais em estado de escassez, leva à associação do conceito ao planejamento e desenho urbanos, ganhando uma conotação que considera relações mais complexas e uma disputa espacial acirrada em escala local, da cidade, e em sítios específicos. Diversos autores (ex.: AHERN, 2007; PAULEIT et al., 2017; CORMIER; PELLEGRINO, 2008; FRANCO, 2010), passaram a dedicar-se sobretudo ao estudo da IEV nestas escalas e atualmente já é

\footnotetext{
${ }^{9}$ Suas inúmeras definições e aplicações, principalmente nos E.U.A. e na Europa, podem ser classificadas em períodos temporais às vezes sobrepostos, que compreendem sua exploração, entre 1998-2007, expansão, entre 2005-2010 e consolidação, a partir de 2010, (MELL, 2017).
} 
possível notar um estreitamento terminológico, marcado pela adição da palavra "Urbana" à Infraestrutura Verde, compondo a Infraestrutura Verde Urbana (IEVu). Focado na escala urbana a partir de princípios básicos da sustentabilidade, AHERN (2007) aponta conceitos ecológicos aplicados à paisagem e assume a Infraestrutura Verde (urbana) “(...) como um modo de organizar espacialmente o meio ambiente urbano para dar suporte a uma série de funções ecológicas e culturais" (AHERN, 2007, p. 267, tradução nossa).

Embora os princípios de IEV (urbana ou não) sigam as variações do próprio conceito, o objetivo de formar uma rede verde multifuncional é recorrente, fator que depende de outro princípio essencial, a conectividade. Portanto, multifuncionalidade e conectividade podem ser considerados princípios centrais da Infraestrutura Verde (BENEDICT; MCMAHON, 2006; PAULEIT et al. 2017). Outro princípio considerado por distintos autores (ex.: HANSE; PAULEIT, 2014; BENEDICT; MCMAHON, 2006; DAVIES et al., 2006), e talvez o mais complexo, está associado à participação de distintos grupos de interesse em processos transdisciplinares para a elaboração de planos e projetos de IEV.

Uma característica ou função bastante explorada da IEVu vem sendo seu potencial para lidar com as águas pluviais. Embora a associação da água às áreas verdes seja intrínseca à própria manutenção das funções verdes da paisagem, como única fonte renovável desse recurso e essencial para que o funcionamento das estruturas ambientais seja mantido (WAGNER; KRAUZE; ZALEWSKI, 2013), a associação direta entre as funções 'verdes' àquelas 'azuis' da Infraestrutura Verde vem sendo enfatizada por distintos autores (ex.: CORMIER; PELLEGRINO, 2008; AHERN, 2007) e políticas públicas (ex.: EPA; MINAM) ${ }^{10}$ podendo originar termos mais específicos como Infraestrutura Verde e Azul, Rede Verde- Azul e Trama Verde Azul ${ }^{11}$. Focadas tanto no

\footnotetext{
${ }^{10}$ Evironmental Protection Agency (EPA, E.U.A.), fornece ferramentas para que técnicas de drenagem sustentável para o manejo das águas urbanas possam ser instaladas nacionalmente. Maiores informações disponíveis em: <https://www.epa.gov/green-infrastructure> Acesso em: 02/10/2016.

Ministerio de Ambiente (MINAM, Peru), propõe a utilização de estratégias de Infraestrutura Natural, ou verde, para a segurança hídrica do país a partir da recuperação de ecossistemas e técnicas ancestrais de manejo das águas (Infraestrutura Verde) nas áreas de cabeceira das bacias hidrográficas que abastecem a costa peruana. Mais informações disponíveis em: <http://www.minam.gob.pe/economia-y-financiamiento-ambiental/inversion-publicaen-servicios-ecosistemicos/> Acesso em: 08/10/2018.
}

${ }^{11}$ Green and Blue Infrastructure (Reino Unido e E.U.A.); Green and Blue Network (E.U.A.); Green- Blue Grid ou GroenBlauwe Netwerken (Holanda); Trame Verte et Bleue (França). 
planejamento de paisagens fluviais como no suporte para a instalação de redes de dispositivos de controle local das águas de chuva, essa relação verde-azul aponta para um outro princípio da Infraestrutura Verde Urbana, a Integração Verde-Cinza. Apesar de ser um contraponto às infraestruturas cinzas e monofuncionais de drenagem, no meio urbano, a IEV não as exclui, pois tem o objetivo de lidar não apenas com as quantidades das águas das chuvas, mas com a remoção de poluentes através de processos naturais (AHERN, 2007). Outro exemplo de integração verde e cinza, vem sendo discutida em relação à mobilidade sustentável (DAVIES et al., 2006; FRANCO, 2010), associada também ao princípio de conectividade, ponto de partida para o desenho das distintas redes de mobilidade.

Se na escala do planejamento, estratégias e ações replicáveis são comuns, uma ação em escala local urbana, onde um sítio ou área especifica é delimitada, representarão características únicas. A análise situacional ou o contexto (urbano, físico, socioeconômico etc.), pode ser elaborada por distintos métodos e pautada por objetivos muito variáveis que também dependerão da escala. A importância do contexto ressalta como um princípio norteador da IEVu e estará associada com a compreensão de características próprias da paisagem local. Finalmente, definir as múltiplas escalas e suas relações faz com que os limites da Infraestrutura Verde Urbana possam ser melhor definidos, assim como o grupo de atores envolvido e o tempo de planejamento ou desenho e instalação de um projeto específico.

Para aplicação urbana, a Infraestrutura Verde será definida como:

Uma rede conectada de espaços abertos, que integra as distintas infraestruturas através das escalas, fornecendo múltiplos serviços ecossistêmicos que beneficiam o bem-estar humano.

A esta definição delimitamos 06 princípios:

1. Multifuncionalidade

2. Conectividade

3. Integração verde - cinza

4. Múltiplas escalas

5. Importância do Contexto

6. Processo transdisciplinar 
Nos seguintes subcapítulos cada princípio será abordado individualmente. As análises comparativas elaboradas para a delimitação dos princípios supracitados podem ser encontradas no Anexo 1.

Quadro 2: Soluções baseadas na Natureza (SbN)

O termo Soluções baseadas na Natureza (SbN, do original, Nature- based Solutions, NbS) surgiu no início dos anos 2000 e vem sendo definido principalmente pelo Banco Mundial, pela União Internacional para a Conservação da Natureza (UICN) e, mais recentemente, pela Comissão Europeia. De modo geral, propõe somar discursos provindos de distintas disciplinas. Inspirado ou como resultado da integração de conceitos tais como Infraestrutura Verde, Infraestrutura Azul, Serviços Ecossistêmicos e biomimetismo pode ser posicionado como ferramenta de desenho e planejamento urbano para tornar as cidades ecologicamente sensíveis (SCOTT; LENNON, 2016; COHEN-SHACHAM et al. (ed.), 2016). Apresentado como parte dos resultados gerados pela pesquisa Horizon 2020, a publicação "Towards an EU Research and Innovation policy agenda for Nature-Based Solutions \& Re-Naturing Cities" (EC, 2015), descreve as SbNs como “(...) ações inspiradas, sustentadas ou copiadas da natureza” (EC, 2015, p. 4, tradução nossa), as quais devem cumprir o duplo objetivo de promover cidades sustentáveis e fomentar o crescimento econômico europeu (ibid). Já a UICN adiciona um diferencial importante, quando define as SbN como ações que deverão proporcionar de modo simultâneo o bem-estar humano e trazer benefícios para a biodiversidade (UICN, 2018). SbN não é, portanto, um conceito novo, mas um termo tão ou mais dinâmico que a Infraestrutura Verde, que pode ser considerado um guarda-chuva conceitual focado em intervenções e ações a partir da busca de soluções baseadas em processos ecológicos, ou naturais, para problemáticas ambientais.

Fonte: elaborado pela autora.

\subsection{MULTIFUNCIONALIDADE}

Pensar a multifuncionalidade da paisagem pressupõe uma visão holística e o trabalhado em formato de equipes transdisciplinares, capazes de efetivar propostas que integrem os sistemas naturais aos culturais (NAVEH, 2001; O'FARRELL; PIPPIN, 2010). Essa característica, traça a 
diferença entre a mera sobreposição de funções acumuladas na paisagem e a proposta de que uma mesma parcela poderá desempenhar distintas funções simultaneamente (SELMAN, 2009). Conhecer e assumir os processos das paisagens é essencial para que a multifuncionalidade possa ser proposta e colabora para a quebra do paradigma do planejamento e desenho de paisagens meramente cênicas em direção a paisagens integrativas, onde funções, bens, serviços e cultura estejam intrínsecos (SELMAN, 2009; KOH, 2011).

Para a Infraestrutura Verde isso significa a mudança entre propormos um verde genérico ou uma rede conectada por estruturas lineares de distintas larguras e extensões, capaz de manter funções sinérgicas e gerar diversos serviços, tanto relacionados a objetivos de potencialização de qualidades ecossistêmicas (BENEDICT; MCMAHON, 2006), quanto à promoção de espaços para a recreação, cultura, etc., compatíveis ao conceito de uso do solo sustentável (AHERN, 1995). Ao ser instalada como uma rede, a IEV considera que não será sempre necessário que cada parcela forneça distintos serviços simultaneamente, mas sim, que como uma rede interconectada, possa garantir a provisão desses serviços (ibid). A dificuldade vem sendo delimitar a escala ou os limites territoriais dessa rede verde e por isso, podemos assumir que os objetivos e expressões da multifuncionalidade da IEV estará associado à escala abordada. Por exemplo, no âmbito regional, ou mesmo local (da cidade e suas áreas periurbanas), o formato em rede será privilegiado, associado à proposta de estratégias e diretrizes de planejamento. De modo geral, quanto menor a escala mais a característica de múltiplo funcionamento irá recair sobre os limites das parcelas ou lotes e estará relacionada ao desenho de lugares e demandas específicas.

Com foco na escala urbana, será possível encontrar diferentes expressões de multifuncionalidade. Uma determinada área verde poderá fornecer distintos serviços ao mesmo tempo, por exemplo, espaços para lazer, para biodiversidade e regulação microclimática (PAULEIT et al. 2017), enquanto outro espaço aberto (verde e não verde), poderá ter funções intervaladas relacionadas à detenção de águas pluviais em determinados períodos e a utilização dos espaços para esportes quando não há chuva (Figuras 4 e 5).

Podemos assumir que a multifuncionalidade parte do objetivo de gerar sinergias entre 0 fornecimento de distintos Serviços Ecossistêmicos ao mesmo tempo que evita ou reduz possíveis trade-offs e desserviços (PAULEIT et al., 2017; para as definições dos termos ver Parte I- Capítulo 
2). Essa integração entre os conceitos de IEV e os Serviços Ecossistêmicos tem se mostrado útil na compreensão e mensuração dos múltiplos serviços prestados pela primeira (HANSEN; PAULEIT, 2014; BARÓ, 2016) e serão abordados em maior detalhe no Capítulo 3.

Figura 4 (esq.): Parque urbano para atividades de lazer e recreação com espaços que valorizam a biodiversidade e áreas inundáveis de grande capacidade (Copenhagen).

Figura 5 (dir.): Praça esportiva inundável durante eventos chuvosos (Roterdã).

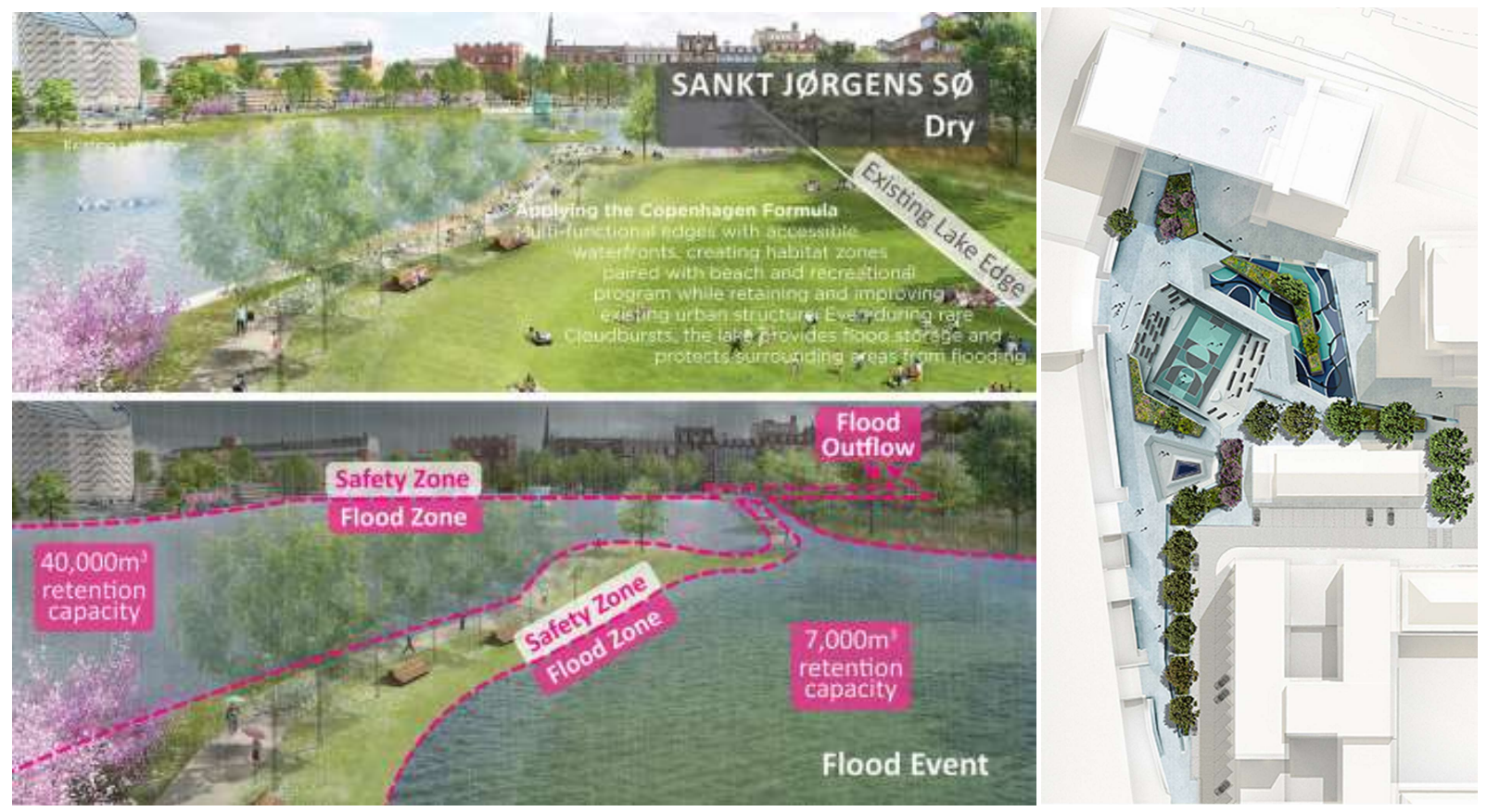

Fontes: Figura 4: Studio Dreiseitl (2017) e Figura 5: De Urbanisten (2017).

\subsection{CONECTIVIDADE}

BENEDICT e MCMAHON (2006) propõem que, para o planejamento da Infraestrutura Verde, seja necessário identificar os Hubs, Links e Sites, traduzidos e ajustados por nós ao contexto urbano respectivamente como, Polos, Conexões (ou Corredores) e Fragmentos (Figura 6), para que a conexão da rede de espaços verdes possa ocorrer e se manter.

A nomenclatura em português ponderou aspectos definidos pelo Paisagismo Ecológico (FORMAN; GODRON, 1986) em relação ao processo de fragmentação da paisagem, e dos ecossistemas, como consequência da ruptura das matrizes ambientais. Segundo Forman e Godron, (1986), a paisagem, ou o mosaico da paisagem, é composta pelos elementos matriz, 
fragmento e corredor (matrix- patch-corridor model). A matriz representa a tipologia de cobertura do solo que predomina em um determinado território. A compartimentação da matriz, por distintos usos e ocupações é responsável pela geração de fragmentos que poderão ou não ser conectados por elementos lineares denominados corredores (FORMAN; GODRON, 1986).

Figura 6: Esquema adaptado “Mosaico Verde" - Polo, Fragmento, Conexão

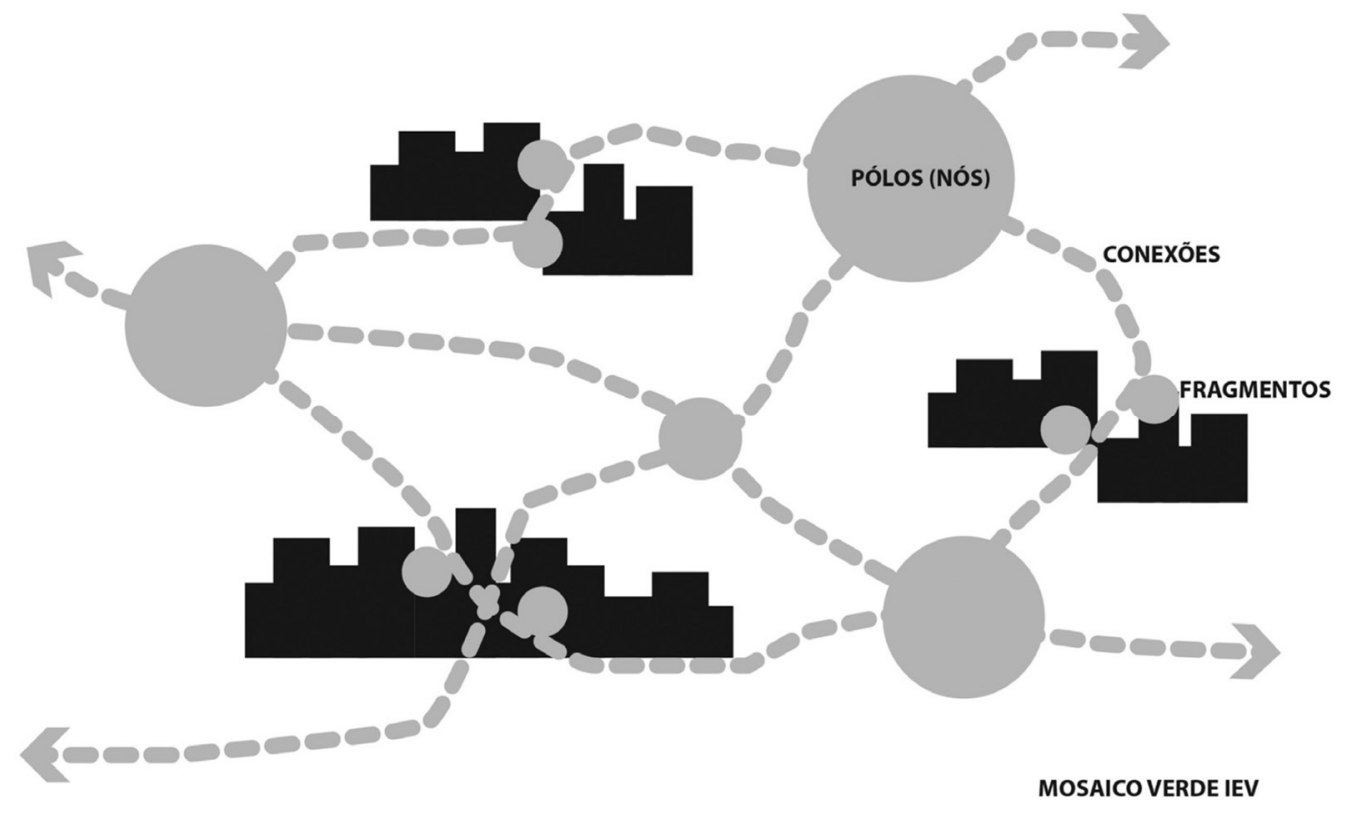

Fonte: MARQUES, T. (2017a, p. 228)

No nosso caso, a denominação fragmentos, não é tradução literal do termo em inglês sites (sítios ou lugares), mas carrega o significado do processo temporal envolvido na sua formação e seu impacto para os ecossistemas, conforme define o Paisagismo Ecológico. Conexões e Corredores serão usados como sinônimos. Os Polos são caracterizados como áreas verdes capazes de ancorar uma rede de IEV para a promoção de funções ecossistêmicas, do desenvolvimento da fauna e da flora além de promover espaços para atividades de lazer (BENEDICT; MCMAHON, 2006). Os Fragmentos, são compostos pelas áreas verdes de menores dimensões que os Polos, dispersos e que podem ou não guardar características ecossistêmicas do ambiente original, mas que ainda são capazes de promover funções, sobretudo culturais. Finalmente, os Corredores são as estruturas que garantem a unidade do sistema, as Conexões, 
essenciais para manter ativos os processos ecológicos entre os Polos através de uma rede de Fragmentos verdes conectados. Vale ressaltar que Polos, Fragmentos e Corredores, são elementos estruturadores da paisagem vinculados a conceitos e disciplinas que abrangem escalas territoriais (Infraestrutura Verde, conforme definida por Benedict e McMahon, 2006 e o Paisagismo Ecológico, conforme definido por Forman e Godron, 1986) e terão que ser adaptados à escala urbana.

Quando analisamos uma área extremamente pavimentada e ambientalmente manipulada como as áreas consolidadas da cidade de São Paulo, fica evidente a escassez de áreas verdes intraurbanas, o que infere a dificuldade de criação de uma rede verde interconectada e multifuncional. Neste caso, a conectividade passa a ser dependente da busca por distintos Espaços Abertos (verdes ou não) e muitas vezes por aqueles espaços não abertos como oportunidade de mudança do uso do solo. Essa redução de escala, do território à cidade, induz a alteração dos objetivos do Corredor. Em escalas territoriais, o principal objetivo dessas ligações é a criação de conexões ecossistêmicas para a melhora da biodiversidade podendo ser denominado Corredor Ecológico ou Corredor de Biodiversidade (ver quadro 1, INTRODUÇÃO- Capítulo 2). Na escala urbana, os benefícios para a biodiversidade são mais restritos considerando-se as dimensões, também mais restritas dos corredores, e as funções relacionadas à recreação e lazer passam a ser priorizadas, nos chamados Caminhos ou Corredores Verdes e ao longo dos Parques lineares. Segundo Ahern, (1995), os Corredores Verdes, podem ser definidos como:

“(...) redes de espaços que conectam elementos lineares planejados, desenhados e gerenciados para múltiplas propostas, incluindo aquelas ecológicas, recreacionais, culturais e estéticas ou outras propostas compatíveis ao conceito de uso do solo sustentável" (AHERN, 1995, p.42, tradução nossa).

A definição de Fragmentos e Corredores urbanos deverá então ser adaptada segundo a escala de abrangência, ou flexibilizada dentre as distintas escalas abordadas, porém sem perder o vínculo funcional característico conforme apresentado anteriormente. No caso da cidade ou metrópole de São Paulo, grosso modo, podemos considerar Polos, os grandes parques estaduais; Fragmentos, os parques urbanos municipais e estaduais; Corredores, os parques lineares. Quando reduzimos a escala para a bacia hidrográfica, por exemplo, os Fragmentos poderiam também 
estar compostos por praças e outros espaços verdes abertos de uso público e os corredores poderiam somar as vias ou rotas arborizadas acessíveis às pessoas.

Num formato propositivo, o conjunto de Espaços Abertos irá considerar todas as áreas não edificadas, verdes ou não, como oportunidades de serem incorporadas a uma rede de IEV. A trama formada pelo conjunto de infraestruturas lineares instaladas terá papel essencial em contextos urbanos consolidados como o da área de estudo da tese e sua abordagem parte de uma visão oportunista às infraestruturas (AHERN, 1995). Esta característica estará associada ao princípio de Integração Verde-Cinza detalhado mais adiante.

Outro conceito que poderá ser um instrumento bastante efetivo para a conectividade da rede verde intraurbana em áreas com grandes restrições de Espaços Abertos será a Floresta Urbana. Geralmente definida como o conjunto de árvores e florestas dentro e nos arredores urbanos, responsáveis por gerar benefícios psicológicos, sociológicos, econômicos e estéticos (KONIJNENDIJK et al., 2005), a Floresta Urbana poderá ser planejada em substituição a um Plano de Arborização Viária, abrangendo um caráter mais amplo, urbano e de manejo das espécies exóticas ou nativas a serem plantadas (PELLEGRINO, 2017b). Em contraponto ao Plano de Arborização Viária, normalmente focado apenas na disposição genérica de árvores ao longo do sistema viário, um Plano de Floresta Urbana considera o conjunto de funções desempenhadas para o fornecimento de distintos Serviços Ecossistêmicos e traz um aporte temporal importante, quando considera o manejo efetivo das árvores urbanas.

\subsection{INTEGRAÇÃO VERDE E CINZA}

O estudo das avenidas de fundo de vale como eixos multifuncionais se baseia numa estratégia oportunista (AHERN, 1995), que visa a adaptação de infraestruturas lineares existentes, de transporte, drenagem e energia, para receber a Infraestrutura Verde no meio urbano. Assumir as interações e integrações possíveis entre a IEV e as infraestruturas cinzas não significa necessariamente limitar a amplitude e complexidade dos sistemas ambientais, recaindo sobre o próprio paradigma infraestrutural discutido na pesquisa. Ao invés disso, busca-se a identificação de limites ou falta de, entre princípios ecológicos que propõem que processos biofílicos possam 
ser responsáveis pela forma urbana (HOUGH, 1995), e as condições urbanas existentes, mas com possibilidades de mudança.

Apesar de normalmente estar associada como antítese às infraestruturas cinzas, ou tradicionais, de drenagem, mobilidade, energia etc., no meio urbano as estratégias de IEV não as exclui (AHERN, 2007) e a integração verde-cinza passa a ser especialmente relevante a esta escala de abordagem. Isso ocorre porque a cidade consolidada já não permite a retomada completa de todos os processos e dinâmicas naturais, existentes antes do assentamento humano, e deve agregar uma quantidade de atividades e usos do solo, que já não possuem área suficiente para serem segregadas, tendendo à disputa por Espaços Abertos bastante limitados. O próprio sistema viário vem sendo alvo dessa discussão, pois as ruas já não são vistas apenas como espaços para a mobilidade, mas como espaços de encontro e recreação (COSTA, 2014), como diria Jackson, "As ruas já não conduzem a lugares, elas mesmas são lugares"12 (JACKSON, 1994, p. 190 apud CARERI, 2013, p. 19).

Essa característica aporta diretrizes de mobilidade distintas, baseadas na priorização dos modos ativos (caminhada e bicicleta, por exemplo) em detrimento aos motorizados público e privados, invertendo a chamada pirâmide de hierarquia da mobilidade (ITDP, 2017). A relevância das áreas verdes urbanas, constituídas como uma rede de IEV, passa a dar o suporte necessário para que a prevalência do pedestre e da bicicleta possa ocorrer ao longo das ruas ou por caminhos sem a presença do automóvel, sendo também incorporadas ao longo de rotas de modos de transporte coletivo não poluentes reforçando assim a ideia de conectividade, também central no planejamento dos sistemas de mobilidade. Essa é uma estratégia de retomada da memória dos antigos caminhos e trilhas (FRANCO, 2010), ao mesmo tempo que se adaptam às necessidades urbanas contemporâneas que defendem a aplicação de estratégias de humanização dos espaços públicos (GEHL, 2010). Um bom modelo de mobilidade, baseado preferencialmente num sistema pedonal e de transporte público eficientes, poderá desempenhar um papel articulador dos espaços abertos urbanos formando um sistema de espaços ligados por corredores verdes (RUEDA, 2001). Nesse sentido, o estudo de Marques e Batistella (2016), nos arredores da avenida Imirim e Engenheiro Caetano Álvares, no vale do córrego Mandaqui em São Paulo, aponta a

12 JACKSON, J. B. A sense of place, a sense of time. New Haven, Yale University Press, 1994, p. 190. 
preferência dos pedestres em caminhar pelas áreas arborizadas do canteiro central da segunda avenida ao invés das calçadas laterais, sem arborização, e indicam a falta de vegetação ao longo da Imirim como um dos fatores de desconforto pedonal e sentimento de insegurança em relação aos carros que circulam próximos às calçadas (MARQUES; BATISTELLA, 2016).

O mosaico heterogêneo de espaços abertos e construídos impõe limites, que podem ser superados ou não, e dependem de fatores tais como desenho, gestão e financiamento, mas fornecem oportunidades de distintas magnitudes para a incorporação da Infraestrutura Verde Urbana e a formação do que poderá ser chamado Continuum verde- cinza (DAVIES et at., 2006; Figura 7) em paródia à ideia de Continuum Naturale.

Figura 7: Continuum verde-cinza.

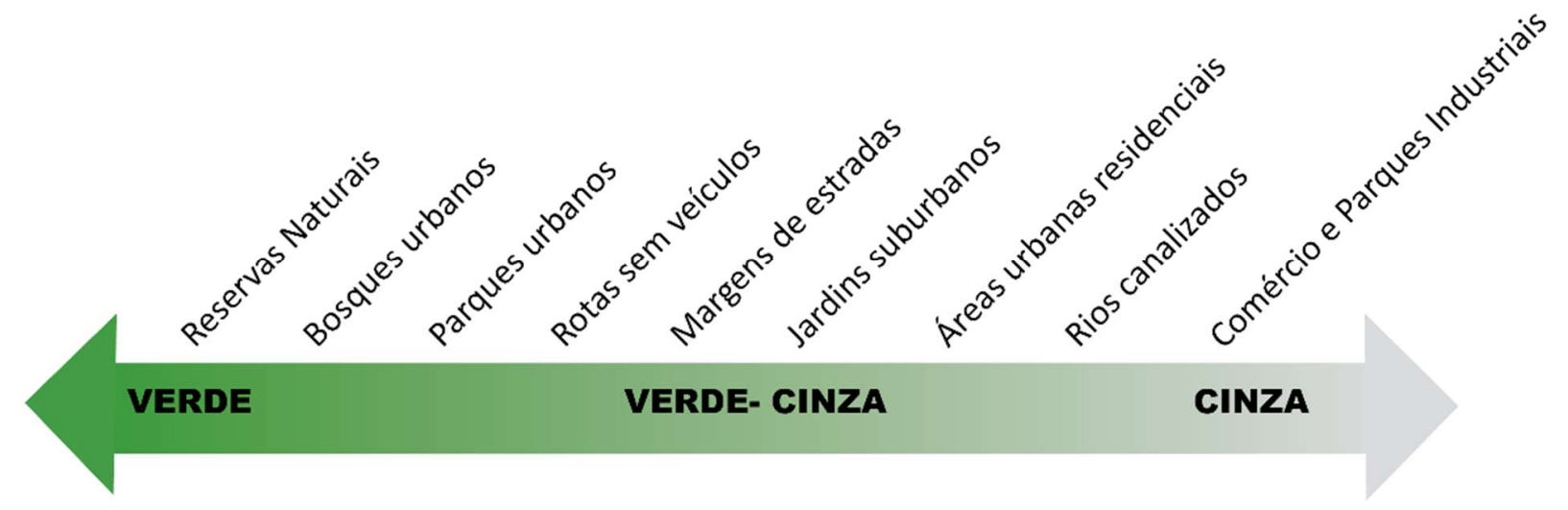

Fonte: adaptado a partir de Davies et at. (2006).

Especificamente quanto à interação verde-cinza e azul, a integração entre dispositivos de drenagem que reproduzem processos ecológicos e dispositivos tradicionais, pretende a flexibilização do sistema ao relacionar métodos deterministas àqueles com um certo grau de imprevisibilidade, característica dos processos ecossistêmicos em suas distintas escalas (AHERN et al., 2012). O grau de risco inerente à complexidade dos sistemas ambientais não pode ser meramente controlado de acordo às necessidades humanas (como vem sendo proposto por exemplo pelos piscinões urbanos em São Paulo; ver Parte I- Capítulo 5), pois os distúrbios são parte inerente dos ecossistemas (ibib). As paisagens, sustentáveis, deverão considerar um certo nível de 'deixar acontecer', garantindo que os sistemas evoluam e se flexibilizem ao longo do 
tempo (SELMAN, 2009; KOH, 2011), fornecendo distintas experiências e informando as pessoas, ao revelar (ou permitir) os processos ecológicos. O que se busca em áreas urbanas consolidadas, é um caminho para que o desenho urbano possa ser um meio de conceber e dar forma a um sistema complexo (LYLE, 1994) que considere o dinamismo dos processos naturais (HOUGH, 1995), ao invés de se fechar em formalismos que repliquem o modus operandi das urbanizações brasileiras e de suas infraestruturas de drenagem. Podemos considerar que o grau de risco, ou de incerteza, poderá então estar associado a sistemas desenhados para serem seguros ao falhar (AHERN, 2011), ou seja, que possuam a capacidade de se reorganizar e se recuperar depois de mudanças ou perturbações.

À primeira vista, a descrição acima pode parecer inviável ou meramente poética, confrontada com o modo como historicamente construímos nossas cidades, sem considerar os ecossistemas e compreender seus distúrbios. Ao mesmo tempo soa como a possibilidade de mudança e adaptação frente à falência das redes de sistemas ao lidar com as dinâmicas e incertezas climáticas, principalmente relacionadas ao manejo das águas de chuva urbanas, e transcender a um modo de aceitação dessas águas, ao invés de enfatizar o já frustrado modo de afastamento da águas a qualquer custo ${ }^{13}$.

Nesse sentido, várias técnicas vêm sendo desenvolvidas e aplicadas, sobretudo na última década, suportadas por políticas públicas que pretendem lidar com a quantidade e a qualidade das águas de chuva urbanas (ex.:EPA). Apresentamos aqui alguns dos termos mais difundidos e aplicados atualmente, indicando o país ou região onde são mais utilizados: Dispositivos de Baixo Impacto (Low Impact Development- LID, E.U.A.); Sistema de Drenagem Urbana Sustentável (Sustainable Urban Dreinage Systems- SUDS, Reino Unido); Desenho Urbano Sensível à Água (Water Sensitive Urban Design- WSUD, Austrália e Reino Unido); e Melhores Práticas de Manejo (Best Management Practicies- BMPs, E.U.A.). O Projeto Jaguaré se baseou na aplicação dos dispositivos de baixo impacto, mantendo o acrômio conforme o nome original em inglês, LID (UCAA, 2010). A proposta foi dispersar os dispositivos na bacia hidrográfica, em micro e macro

\footnotetext{
${ }^{13}$ No momento de revisão final deste trabalho, São Paulo vem passando por uma de suas piores inundações urbanas (fevereiro de 2020), acompanhado por cidades de outros estados brasileiros, especialmente em Minas Gerais.
} 
escalas a fim de simular a eficácia do sistema e de cada tecnologia para o controle da qualidade da água quanto à remoção de cargas difusas (ver Parte I- Capítulo 5). A viabilidade da aplicação dessas técnicas em escala urbana irá variar entre integrações mais ou menos efetivas das infraestruturas verde-azul-cinza (Figura 8).

Figura 8: integração verde-azul-cinza.

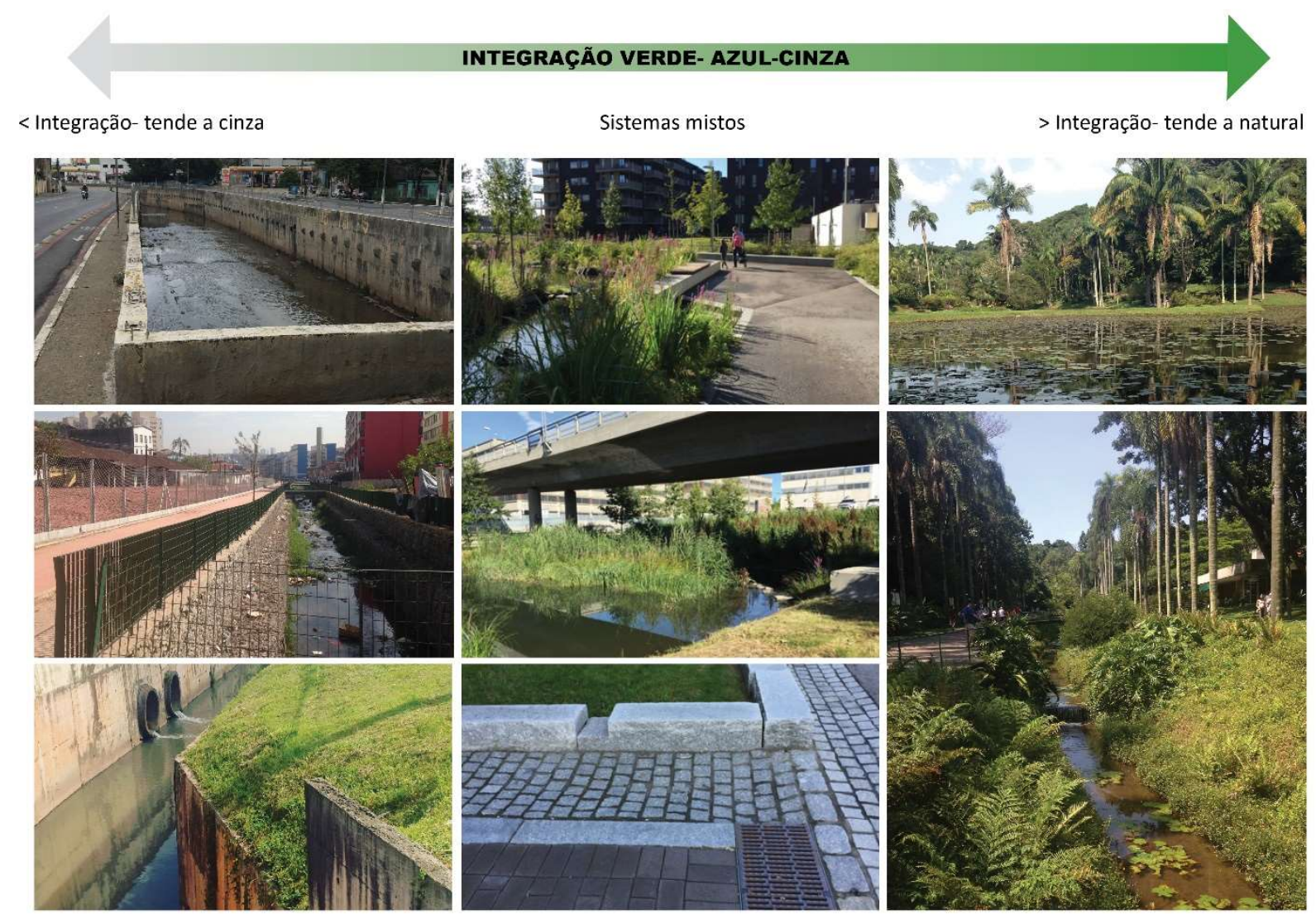

Fonte: elaborado pela autora.

\subsection{MÚLTIPLAS ESCALAS}

A falta de rigor na definição de uma escala de abordagem comum tem sido descrita como um dos fatores que dificultam a delimitação do conceito de Infraestrutura Verde (HANSE; PAULEIT, 2014). Essa dificuldade é compreensível, considerando os diferentes métodos, processos e ferramentas destinados à proposição de planos em escala regional ou urbanos, ou para o desenho 
em sítio específico. Como mencionado anteriormente, a multifuncionalidade e a integração verde-cinza são princípios também variáveis em relação à escala abordada.

De modo geral, cada escala abordada deverá levar em conta escalas próximas, maiores ou menores, com a finalidade de garantir a conectividade do sistema e compreender possíveis impactos locais advindos de fenômenos regionais ou vice-versa. A aplicação prática desse princípio levará em consideração o tamanho da área de estudo e o nível de detalhe, ou percepção física desejável (NUCCl, 1998).

No contexto da tese, o fundo de vale é o objeto central, mas para que seja possível compreender as dinâmicas relacionadas às águas nestas porções da paisagem, a escala da bacia hidrográfica deve ser abordada e para evidenciarmos as integrações das infraestruturas verde e cinza, a escala de cortes amostrais em locais específicos será explorada. O nível de detalhe explorado para a bacia é o da quadra, e a escala utilizada 1:5000. O fundo de vale requer uma interpretação a partir do tamanho e ocupação do lote, definindo-se assim a escala em 1:2000. Já os cortes em locais específicos poderão variar entre 1:500 e 1:250 (Figura 9).

Figura 9: Distintas escalas abordadas pela tese.

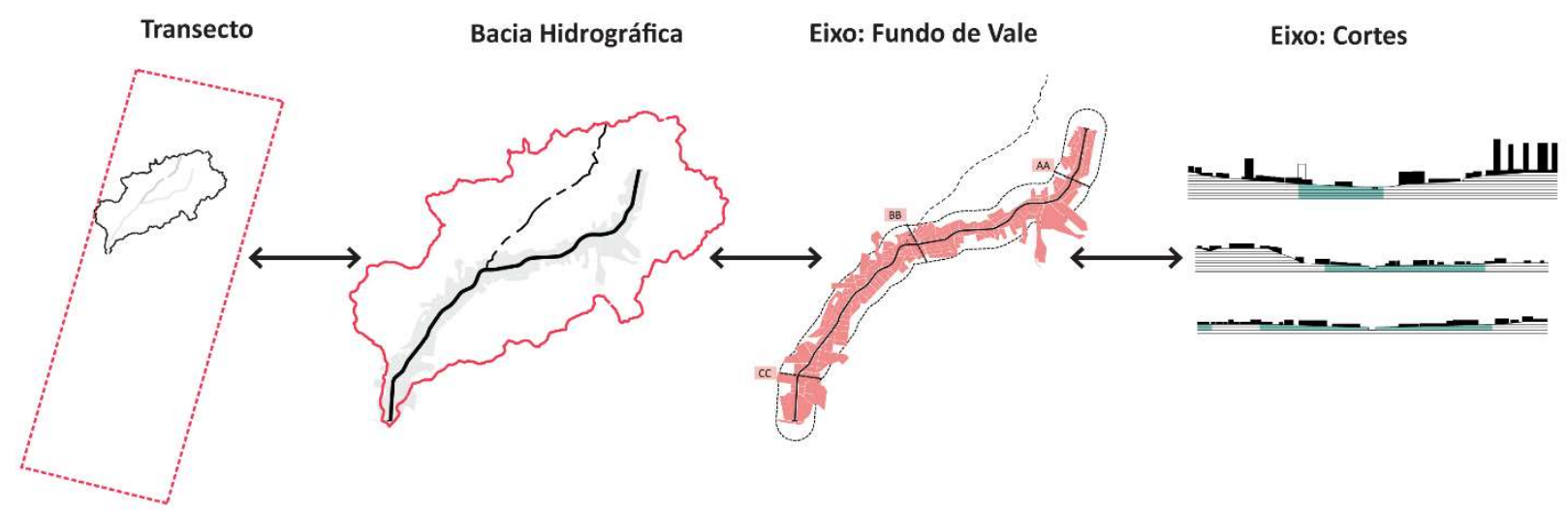

Fonte: elaborado pela autora.

\subsection{IMPORTÂNCIA DO CONTEXTO}

A instalação da Infraestrutura Verde Urbana parte do entendimento dos processos de paisagem (BENEDICT; MCMAHON, 2006). Segundo Christofoletti (1981), “As paisagens 
constituem respostas a um complexo de processos, cada um exigindo apropriadas escalas espacial e temporal para serem estudados“" (CHRISTOFOLETTI, 1981, p. 113).

O contexto engloba a análise das características físicas, bióticas e de uso e ocupação do solo. Para sítios específicos, também será relevante identificar quais são os atributos que fornecem uma identidade própria ao lugar, assim como acessar o grupo de população diretamente afetada pela intervenção. Na escala da bacia hidrográfica será feita a Compartimentação da Paisagem, com o objetivo de compreender o impacto da urbanização sobre os processos naturais e mapear setores passíveis de regeneração a curto, médio e longo prazos (SCHUTZER, 2012). O inventário de Espaços Abertos caracterizados quanto a sua posição na bacia e características físicas e ecológicas irá fomentar uma base para o entendimento da demanda por áreas verdes urbanas e um panorama da aptidão de cada tipologia em fornecer distintos Serviços Ecossistêmicos (ver Parte II- Capítulo 4). O fundo de vale será analisado de acordo com os distintos contextos de uso e ocupação do solo ao longo do eixo.

\subsection{PROCESSO TRANSDISCIPLINAR}

Nesse princípio foram unificadas duas demandas importantes, uma quanto à participação do grupo formado pelos distintos atores, públicos, privados e formado pelo conjunto de cidadãos, interessados e/ ou beneficiados por planos e projetos de Infraestrutura Verde. Outro, quanto à equipe técnica e de pesquisa normalmente envolvida nesse processo. O termo transdisciplinar é proposto a partir da diferenciação sugerida por Tress, Tress e Fry (2004), em relação à multidisciplinaridade, interdisciplinaridade e transdisciplinaridade aplicadas à pesquisa em Ecologia da Paisagem e que poderão compor os processos de planejamento da Infraestrutura Verde (Figura 10).

Segundo os autores, a multidisciplinaridade existe quando múltiplas disciplinas propõem múltiplos objetivos, guiados por um tema geral comum sem que haja uma cooperação ou troca entre essas disciplinas, havendo o desenvolvimento independente de teorias. A interdisciplinaridade garante que os limites de cada disciplina sejam cruzados e se proponham objetivos comuns, havendo a integração das disciplinas e o desenvolvimento de conhecimentos e teorias integradas. Finalmente, em processos transdisciplinares os limites científicos ou 
acadêmicos são cruzados e para alcançar um objetivo comum, participantes acadêmicos e não acadêmicos desenvolvem conhecimentos que permeiam teorias científicas e aspectos da sociedade (TRESS; TRESS; FRY, 2004).

Figura 10: Gráfico esquemático com os graus de integração e o envolvimento de atores em processos integradores e não integradores.

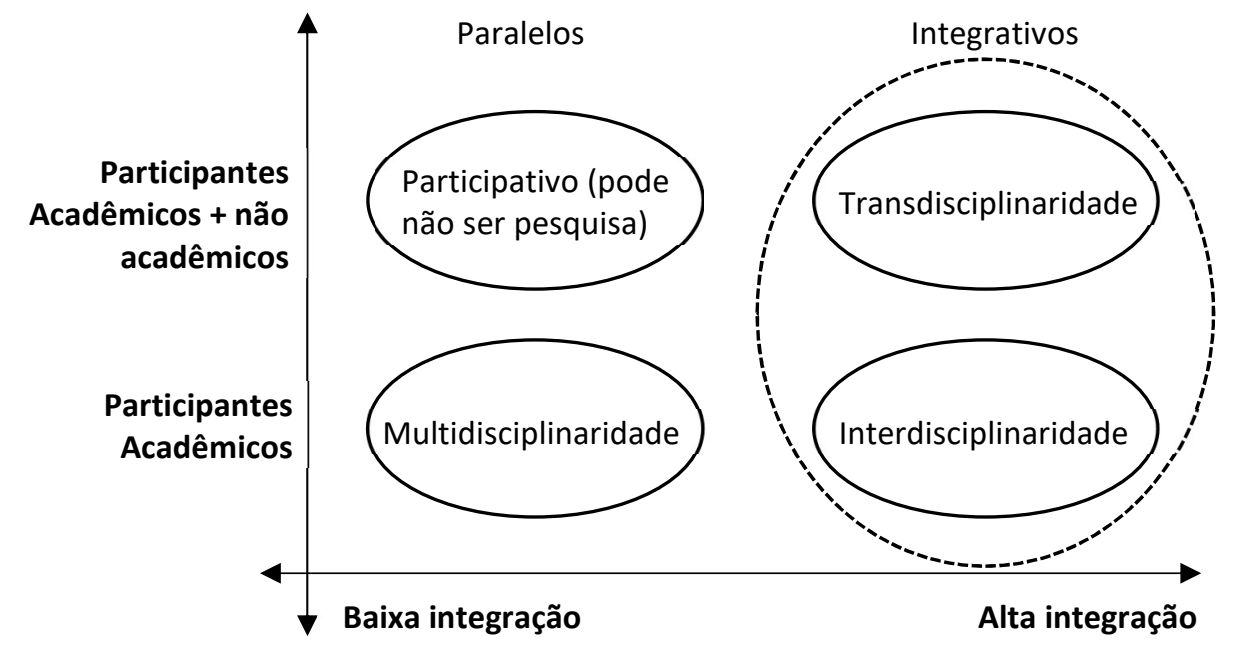

Fonte: adaptado a partir de Tress, Tress e Fry, (2004), (tradução nossa).

Um dos entraves ao princípio transdisciplinar considera que embora a gestão adaptativa de sistemas naturais venha sendo empregada com sucesso, em planejamento e desenho urbano a gestão flexível raramente é encontrada (AHERN, 2011). A visão de paisagens mais integradas, a partir da criação de uma rede verde, deve superar tanto barreiras sociais quanto aquelas existentes na própria estrutura organizacional das políticas urbanas, que se caracteriza por múltiplos e segregados setores que falham ao lidar com a complexidade da temática urbanoambiental- social (RUNHAAR et. al, 2009, apud ANDERSSON et. al, 2014, p. 446) ${ }^{14}$.

Durante a última revisão do Plano Diretor Estratégico de São Paulo (PDE, 2014), da Lei de Parcelamento, Uso e Ocupação do Solo (LPUOS, 2016) e principalmente dos Planos Regionais Estratégicos (PRE, 2016), houve a consideração de um processo de envolvimento da população,

\footnotetext{
14 RUNHAAR et. Al. Runhaar, H.A.C., P.P.J. Driessen, and L. Soer. Scientific commons: Sustainable urban development and the challenge of policy integration: An assessment of planning tools for integrating spatial and environmental planning in the Netherlands. Environment and Planning B: Planning and Design 36: 417-431.2009.
} 
o que sem dúvidas é um avanço e gera um histórico para as políticas públicas locais. A elaboração do Manual de Drenagem e Manejo das Águas Pluviais (SMDU, 2012) é outro exemplo positivo, tendo sido liderado pela Secretaria Municipal de Desenvolvimento Urbano (SMDU) contando com a colaboração da Secretaria Municipal de Infraestrutura Urbana e Obras (SIURB), da Secretaria Municipal de Coordenação das Subprefeituras (SMSP), da Secretaria Municipal de Habitação (SEHAB) e da Secretaria Municipal do Verde e do Meio Ambiente (SVMA). Se por um lado o processo colaborativo dessas secretarias tenha sido um avanço, por outro ainda falta justamente uma organização inter ou transdisciplinar que envolva diagnóstico, proposição, implementação e monitoramento das estratégias definidas conjuntamente.

No contexto da tese, os processos de colaboração na pesquisa estão caracterizados por processos multi e interdisciplinares e demonstram interesses de dois órgãos públicos financiadores de pesquisas, Fapesp e FEHIDRO, pelo tema da Infraestrutura Verde dedicada ao manejo das águas urbanas e suas outras possibilidades para o enfrentamento de distintos impactos gerados pelas mudanças climáticas. No caso do Projeto Jaguaré, o trabalho teve característica interdisciplinar, a partir da proposta de objetivos conjuntos enfrentados a partir de discussões e integrações teóricas e metodológicas complementares entre as disciplinas Arquitetura e Urbanismo, Arquitetura da Paisagem e das Engenharias Civil e Ambiental. Quanto o Projeto Resiliência Urbana, a conformação de uma equipe multidisciplinare atuou em distintas frentes de trabalho, avançando os estudos da IEV para uma gama de objetivos. O dinamismo das equipes envolvidas nos dois projetos soa inovadora num contexto de profissões com posicionamento marcadamente narcisistas (arquitetos urbanistas e engenheiros civis) e muitas vezes antagonistas quanto à visão de mundo. Segundo Fry (2001), os maiores empecilhos enfrentados pelos processos de pesquisas colaborativa relacionadas a paisagem, vem sendo as tradições acadêmicas, os sistemas de méritos e a falta de teorias. Uma abordagem multidisciplinar e sobretudo inter ou transdisciplinar certamente nos aproxima de um plano ou projeto mais holístico e colabora para a mudança de paradigmas ambientais no desenho de nossas cidades. 


\section{SERVIÇOS ECOSSISTÊMICOS}

Os Serviços Ecossistêmicos (SE), também traduzido como Serviços Ambientais no Brasil, podem ser definidos como os benefícios obtidos pelas pessoas a partir de distintas funções ecossistêmicas (DE GROOT; WILSON; BOUMANS, 2002; MA, 2005), ou seja, são as contribuições diretas e indiretas que favorecem o bem-estar humano a partir dessas funções (CONSTANZA et al., 1997; TEEB, 2011). Portanto, pode-se assumir que os SE somente são considerados serviços se a eles estão associados benefícios, consumidos ou usufruídos pelas pessoas, (HAINES-YOUNG; POTSCHIN, 2010).

O termo Serviços Ecossistêmicos (SE), foi utilizado pela primeira vez na década de 70, pelo 'Estudo dos Problemas Ambientais Críticos', (tradução nossa a partir de Study of Critical Environmental Problems- SCEP, 1970 apud HAINES-YOUNG; POTSCHIN, 2010, p. 111) ${ }^{15}$. Assim como a Infraestrutura Verde, os SE se tornaram um tema recorrente a partir dos anos 90, sendo alvo de inúmeras pesquisas, críticas e aplicações desde então. 0 crescimento no interesse pelos dois conceitos foi bastante motivado pelas primeiras definições de sustentabilidade e a reverberação global de que governos deveriam agir o mais rápido possível, a fim de garantir a qualidade ambiental, econômica e social para as próximas gerações (Relatório de Brundtland, 1987). ${ }^{16}$ A popularização dos Serviços Ecossistêmicos se dá principalmente a partir da publicação de Constanza et al. (1997), que avaliou economicamente o valor dos sistemas naturais do planeta, abrindo a possibilidade para que novos mercados relacionados ao fornecimento dos serviços da natureza fossem criados, tais como os Pagamentos por Serviços Ecossistêmicos.

A diferenciação entre as funções, serviços e benefícios dos ecossistemas vem permeando a aplicação de metodologias que visam o mapeamento e a quantificação de suas demandas e fornecimentos (DE GROOT, et al., 2010; HAINES-YOUNG; POTSCHIN, 2010; BURKHARD et al., 2012), carregando um certo grau de subjetividade quando especificados (BURKHARD et al., 2012). A definição amplamente divulgada a respeito dos tipos de Serviços Ecossistêmicos que podem ser

\footnotetext{
15 Study of Critical Environmental Problems (SCEP). Man's Impact on The Global Environment: Assessment and Recommendations for Action. Report, MIT Press Clasic, 1970. Disponível em: <https://mitpress.mit.edu/books/mansimpact-global-environment> Acessado em 10/12/2019.

${ }^{16}$ Report of the World Commission on Environment and Development: Our Common Future, 1987.
} 
fornecidos pela natureza se baseia em duas publicações, Millenium Ecossystem Assessment (MA, 2005) e The Economics of Ecossystems and Biodiversity (TEEB,2011). Esses documentos tiveram um papel importante em traduzir os modelos teóricos à prática, reconhecendo a importância dos SE e demonstrando o valor econômico total que poderiam ter (GÓMEZ-BAGGETHUN, 2019) ${ }^{17}$. Dessa forma, simplificaram e apresentaram de modo acessível e sedutor economicamente a importância dos SE, dividindo-os em 04 grupos: provisão; regulação; suporte ou habitat; e cultural.

Segundo o TEEB (2011), os serviços de provisão são aqueles baseados nos produtos ou saídas materiais dos ecossistemas tais como, alimentos, água, produtos medicinais etc. Os serviços de regulação são aqueles responsáveis pela manutenção e regulação das funções ecossistêmicas relacionadas à qualidade do ar, do solo, da água (incluindo o manejo da quantidade das águas e o controle de enfermidades). Quanto aos serviços de suporte ou habitat, estes fornecem apoio a todos os outros Serviços Ecossistêmicos e incluem a provisão de espaços para a diversidade de organismos, plantas e animais, produção de biomassa, ciclos de nutrientes etc. Finalmente, os serviços culturais são aqueles não- materiais e incluem os benefícios sócio- ecológicos (por exemplo psicológico e cognitivo), recreacionais e estéticos.

O fornecimento dos SE não é linear ou estático. A capacidade de um ecossistema em prover serviços está relacionada às qualidades biofísicas encontradas em uma determinada área (DE GROOT et al, 2010), portanto, distintos habitats fornecerão diferentes serviços e benefícios, o que faz com que essa classificação genérica deva ser adaptada às diferentes condições sócioeconômicas, ambientais e geográficas (GÓMEZ-BAGGETHUN; BARTON, 2013).

A escala abordada é outro fator de influência no fornecimento dos SE. Por exemplo, na escala do bairro, serviços relacionados à provisão de espaços recreacionais poderão ser priorizados e na escala regional, a provisão de alimentos (HANSE, et al., 2017). Adicionalmente, Braat et al. (2008) ao relacionar o fornecimento dos distintos SE ao uso do solo e à biodiversidade, esclarece que é necessário considerar o conjunto de mudanças e benefícios associados ao fornecimento dos

\footnotetext{
17 Informação fornecida por Gómez-Baggethun durante o Il Congreso de la Sociedad Andina de Economía Ecológica (SAEE): Justicia Ambiental y Alternativas al Desarrollo: aportes de la Economía Ecológica y la Ecología Política, Lima, 2019.
} 
serviços nas distintas escalas, pois interesses privados locais, tal como a agricultura intensiva, poderão ter consequências regionais ou globais.

Na escala urbana, os Serviços Ecossistêmicos impactam diretamente a saúde e o bem-estar dos habitantes. Grosso modo, asseguram qualidades como a purificação do ar, a redução de ruídos, o resfriamento urbano e a mitigação do impacto das águas das chuvas (GÓMEZBAGGETHUN; BARTON, 2013). A condição urbana implica que normalmente estes serviços sejam prestados em associação entre as áreas verdes e as infraestruturas não naturais, além disso, as áreas verdes urbanas podem ter outras funções além dos Serviços Ecossistêmicos tradicionalmente definidos, como por exemplo darem suporte à mobilidade (HANSE et al, 2017).

A heterogeneidade da ocupação do solo e dos sistemas urbanos, passa a ser um desafio motivador para a associação das funções urbanas às ecológicas. A complexidade quanto à valoração dos SE nestas áreas deverá considerar a análise de possíveis sinergias, trade-offs e desserviços para uma abordagem mais holística (HAASE et. al, 2014).

As sinergias ocorrem quando o fornecimento de um determinado Serviço Ecossistêmico melhora os benefícios gerados por outro serviço. Os trade-offs, por outro lado, ocorrem quando o aumento na provisão de um serviço causa a redução dos benefícios gerados pela oferta de outro serviço (TURKELBOOM et. al, 2016). Já os desserviços são aqueles percebidos como negativos ao bem-estar humano e normalmente não estão incorporados nas definições mais conhecidas dos SE (LYYTIMÄKI; SIPILÄ, 2009). São exemplos de desserviços, a possível emissão de gases compostos orgânicos voláteis pelas árvores, responsáveis pela formação de gases tóxicos à saúde humana, e/ ou a interferência das copas nas infraestruturas aéreas e das raízes nas infraestruturas subterrâneas (GÓMEZ-BAGGETHUN; BARTON, 2013).

A importância, ou valor, dos ecossistemas vem acompanhando a aplicação do conceito em distintos lugares. De modo geral, a valoração é dividida em três tipos: ecológica, sociocultural e econômica (DE GROOT; WILSON; BOUMANS, 2002). A valoração ecológica se baseia em métricas provenientes da ecologia, tais como integridade, complexidade e raridade. A abordagem sociocultural é fundamentada em valores sociais como equidade e percepção para determinar a importância de uma determinada área natural em fornecer benefícios subjetivos e imateriais como bem-estar e qualidade de vida (ibid). Já a valoração econômica pretende unificar sob uma 
única métrica comparável, o valor monetário, o conjunto de benefícios diretos, e as vezes também indiretos, que uma determinada área pode fornecer. Uma das razões pelas quais o estudo dos Serviços Ecossistêmicos venha crescendo está exatamente em sua característica integradora entre conceitos ambientais e socioeconômicos, fomentando a formação de equipes inter e transdisciplinares (MÜLLER; BURKHARD, 2007, apud BURKHARD et al., 2009, p.2) ${ }^{18}$.

Cada um dos modelos apresenta incertezas, limites e benefícios. Os ecossistemas são caracterizados por sua complexidade, não linearidade e alta interconectividade, inerente a seus processos e dinâmicas, os quais dependem também de variações temporais e em distintas escalas (CHEE, 2004). Ao mesmo tempo que estes aspectos são essenciais para que os sistemas naturais possam se adaptar a distúrbios, e mantenham a oferta de distintos Serviços Ecossistêmicos, desafiam qualquer método de valoração. No caso dos métodos ecológicos, será necessário considerar a complexidade referente às sinergias, trade-offs e desserviços relacionados às dinâmicas de um determinado ecossistema.

Os métodos baseados na percepção dos serviços culturais normalmente encontram dificuldade em avaliar a complexa relação entre fornecimento e demanda e são dependentes do contexto onde ocorrem, o que faz com que o tema ainda necessite de investigações mais completas (RIECHERS; BARKMANN; TSCHARNTKE, 2016). A maioria dos estudos são provenientes da Europa, E.U.A. e Ásia (ibid) onde o contexto sócio- econômico é normalmente diferente de países sul-americanos como o Brasil. Nesse sentido, há necessidade de ampliar a gama de estudos, de tal forma que possam ser comparativos entre distintas realidades políticas e sócio econômicas.

O modelo econômico, apesar de ter se tornado predominante e amplamente utilizado como forma de convencimento de gestores públicos e investidores, incorre em limitações tais como, os valores de bem-estar humano e aqueles intrínsecos ao meio natural, melhores associados a métricas sociais e ecológicas respectivamente. Além disso, a provisão de distintos

\footnotetext{
18 MÜLLER, F.; B. BURKHARD. An ecosystem based framework to link landscape structures, functions and services. In: MANDER, Ü.; WIGGERING, H.; HELMING, K. (eds.): Multifunctional Land Use - Meeting Future Demands for Landscape Goods and Services, p. 37-64, Berlin - Heidelberg - New York, Springer, 2007.
} 
Serviços Ecossistêmicos por uma mesma parcela de terra pode incorrer em dupla contagem durante a valoração econômica (DE GROOT; WILSON; BOUMANS, 2002).

Identificar quem se beneficia, onde e quando se beneficiam dos SE resultará em aportes metodológicos importantes para a compreensão de suas demandas e fornecimento (DAILY et al, 2009). Distintos autores e organizações (ex.: OMS, 2016; ELMQVIST et al., 2015; MA, 2005; NE, 2010; GRUNEWALD et al., 2015), vem demonstrando a preocupação com a qualidade e a acessibilidade às áreas verdes, fornecedoras dos SE, dando respaldo para que diversos critérios e indicadores de acessibilidade sejam propostos.

A associação das diferentes coberturas de solo ao fornecimento de SE é outro critério que vem sendo pesquisado (BURKHARD et al., 2009; BURKHARD et al., 2012) com o objetivo de identificar a localização espacial dos serviços, suas demandas e o atual ou potencial fornecimento. A identificação das qualidades ecológicas das áreas verdes poderá colaborar para a diferenciação dos serviços prestados (KOWARIK, 2013).

O próximo capítulo irá relacionar os SE à Infraestrutura Verde e em seguida, os métodos, critérios e parâmetros a serem aplicados no caso de estudo serão apresentados. A tese irá avaliar a acessibilidade às áreas verdes na escala da bacia hidrográfica e do fundo de vale, evidenciando o papel dessas áreas quanto à demanda e fornecimento de SE Culturais. 


\section{EIXOS MULTIFUNCIONAIS: A INFRAESTRUTURA VERDE COMO PROVEDORA DE SERVIÇOS ECOSSISTÊMICOS URBANOS}

A promoção dos benefícios resultantes da instalação da Infraestrutura Verde urbana associada ao conceito de Serviços Ecossistêmicos é recente, mas já vem sendo discutida por diversos autores, (ex.: ANDERSSON et al, 2014; AHERN, 2011; HANSE; PAULEIT, 2014; BARÓ, 2016). Bolund e Hunhammar (1999), embora não utilizassem o termo Infraestrutura Verde, propunham simplificar a compreensão do que seria o ecossistema urbano indicando diferentes tipologias de áreas verdes e azuis- mesmo que manipuladas pelo ser humano - intrínsecas à cidade. Definiam assim sete tipologias genéricas: o conjunto formado por árvores ao longo das vias; gramados/ parques; bosques urbanos; áreas cultivadas; wetlands; lagos/ mar; e córregos e consideravam os benefícios que estas áreas poderiam ter para o bem-estar das pessoas. Tzoulas et al. (2007) relacionaram diretamente a Infraestrutura Verde à qualidade dos ecossistemas urbanos e aos benefícios que poderia prover à saúde e ao bem-estar.

Atualmente, algumas políticas públicas internacionais abordam os Serviços Ecossistêmicos como sinônimos ou consequência da Infraestrutura Verde (ex.: European Environmental AgencyEE, 2011 19 apud GÓMEZ; BARTON, 2013, p. 235; MINAM, 2016; EPA), ressaltando o papel tanto da água quanto do verde para o aporte de distintas funções, serviços e benefícios. $O$ documento apresentado pela Comissão Europeia (CE) em 2013 “Green Infrastructure (GI) - Enhancing Europe's Natural Capital"20, afirma justamente a importância da utilização de estratégias de Infraestrutura Verde para o planejamento de áreas naturais e seminaturais projetadas tanto em zonas rurais quanto urbanas e aquáticas e gerenciadas para oferecer uma ampla gama de serviços ecossistêmicos (EC, 2013). A Infraestrutura Verde (e azul) deverá ter um papel crucial na adaptação das cidades frente às mudanças climáticas (ELMQVIST et al., 2015).

O aporte dos SE relacionados à Infraestrutura Verde urbana se justifica devido à possibilidade de interlocução entre os seis princípios de Infraestrutura Verde destacados:

\footnotetext{
${ }^{19}$ EEA (European Environmental Agency). Green infrastructure and territorial cohesion. The concept of green infrastructure and its integration into policies using monitoring systems. EEA Technical report, 18, 2011.

${ }^{20}$ Maiores informações em: <http://ec.europa.eu/environment/nature/ecosystems/index_en.htm> Acessado em: 10/08/2017.
} 
multifuncionalidade; conectividade; múltiplas escalas; importância do contexto; integração verde-cinza e processo transdisciplinar. A relação entre tais princípios é sintetizada pelo desenho dos Eixos Multifuncionais, definidos por nós como elementos lineares capazes de catalisar o verde e o azul na trama urbana, estruturando uma rede de áreas verdes com potencial de fornecer múltiplas funções, serviços e benefícios ecossistêmicos.

Para a Infraestrutura Verde, a multifuncionalidade é um tema central, porém normalmente não mensurada, já os Serviços Ecossistêmicos, são pensados para operacionalizar a multifuncionalidade (HANSE, R.; PAULEIT, S., 2014). A avaliação de uma grande quantidade ou especificidade de SE demanda a formação de equipes multidisciplinares, o que vem resultando em uma das principais barreiras a este tipo de pesquisa atualmente (ibid). A pesquisa focada em um Serviço Ecossistêmico específico, poderá avançar no desenvolvimento do tema localmente e eventualmente reconhecer as possíveis sinergias, trade-offs e desserviços, uma brecha de conhecimento que ainda precisa ser atendida (HAASE et. al, 2014).

A definição de escalas de análise da Infraestrutura Verde, também limita os potenciais SE prestados. No nosso caso, o fundo de vale e a bacia hidrográfica serão escalas interrelacionadas que contribuem para a compreensão da demanda e fornecimento de serviços dedicados à regulação hídrica, aderentes aos estudos dos Projetos Jaguaré e Resiliência Urbana, os quais, juntamente a outros planos existentes para o caso do Mandaqui, formam a base teórica utilizada para a discussão da pesquisa (ver Parte II).

A regulação hídrica é um problema comum às bacias hidrográficas urbanizadas da região metropolitana de São Paulo, afetadas pela deterioração do contexto onde se encontram, previamente composto por processos fluviais que incorporavam uma gama muito mais ampla de serviços, tais como: biodiversidade; áreas para lazer e práticas esportivas; usos econômicos como pesca, navegação, mineração e agrícola (RODRIGUES, 2015). Na escala do fundo de vale, fomentar a criação de um Eixo Multifuncional exigirá que as condições das distintas infraestruturas que compartilham a área (drenagem, verde e de mobilidade) sejam verificadas e analisadas quanto às integrações existentes e possíveis.

Conforme visto no capítulo anterior, oS SE fornecidos em áreas urbanas normalmente estão associados tanto às áreas verdes quanto às infraestruturas cinzas e as áreas verdes poderão dar 
suporte para que a mobilidade ocorra, fatores que estão associados à Integração verde-cinza. Exemplos dessa última interação podem ser encontrados em alguns dos fundos de vale urbanizados de São Paulo, dentre eles os vales dos córregos Mandaqui (av. Engº . Caetano Álvares) e Água Preta (av. Sumaré), e as áreas de várzeas do rio Pinheiros (av. Brigadeiro Faria Lima). O tamponamento dos cursos d'água e saneamento das várzeas, acompanhado pela instalação de avenidas e canteiros centrais arborizados, ao longo do tempo propiciou a volta de atividades humanas excluídas pelo enfoque tradicional de ocupação dessas porções da paisagem. Hoje as áreas verdes centrais a estas avenidas dão suporte para que atividades de lazer, esporte e relacionadas aos modos de mobilidade ativa possam ocorrer (Figuras 11 e 12).

Figuras 11 e 12: Imagens de referência da mobilidade a pé (esq.) e por bicicleta (dir.), ao longo do vale do Mandaqui.
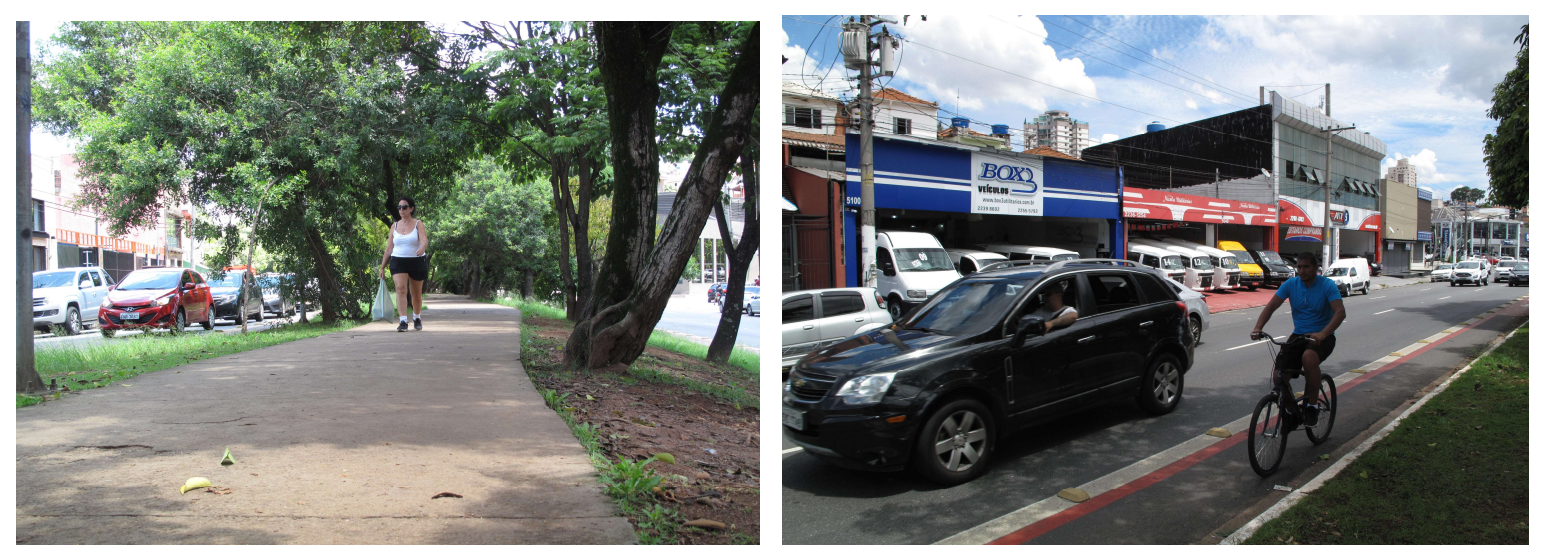

Fonte: autora, 2019.

Para considerarmos a Infraestrutura Verde como provedora de Serviços Ecossistêmicos, será necessária uma clarificação entre os termos função, serviços e benefícios (HANSE; PAULEIT, 2014). No âmbito das discussões teóricas a respeito dos SE, Roy Haines-Young e Marion Potschin vem colaborando com uma produção científica dedicada, dentre outros, ao entendimento das diferenças entre esses três termos. Os autores propõem o Modelo em Cascata dos Serviços Ecossistêmicos, (tradução nossa para "Ecosystem Services Cascade Model", HAINES-YOUNG; POTSCHIN, 2010), a partir da distinção entre as estruturas ecológicas da paisagem e as funções, serviços e benefícios que podem ser derivados através de um processo em cadeia. O modelo não 
é estanque, uma vez que diferenças locais poderão influenciar as definições das funções, serviços e benefícios, caso a caso (HAINES-YOUNG; POTSCHIN, 2010). Nosso objetivo, ao aplicar essa ferramenta, é definir um ponto terminológico comum entre os conceitos Infraestrutura Verde e Serviços Ecossistêmicos, além dos limites e dependências entre os três termos abordados. 0 Modelo em Cascata dos Serviços Ecossistêmicos foi aplicado para o caso da regulação hídrica, conforme interpretação proposta pela autora e pode ser visualizado na Figura 13.

Figura 13: Diagrama do Modelo em Cascata dos Serviços Ecossistêmicos.

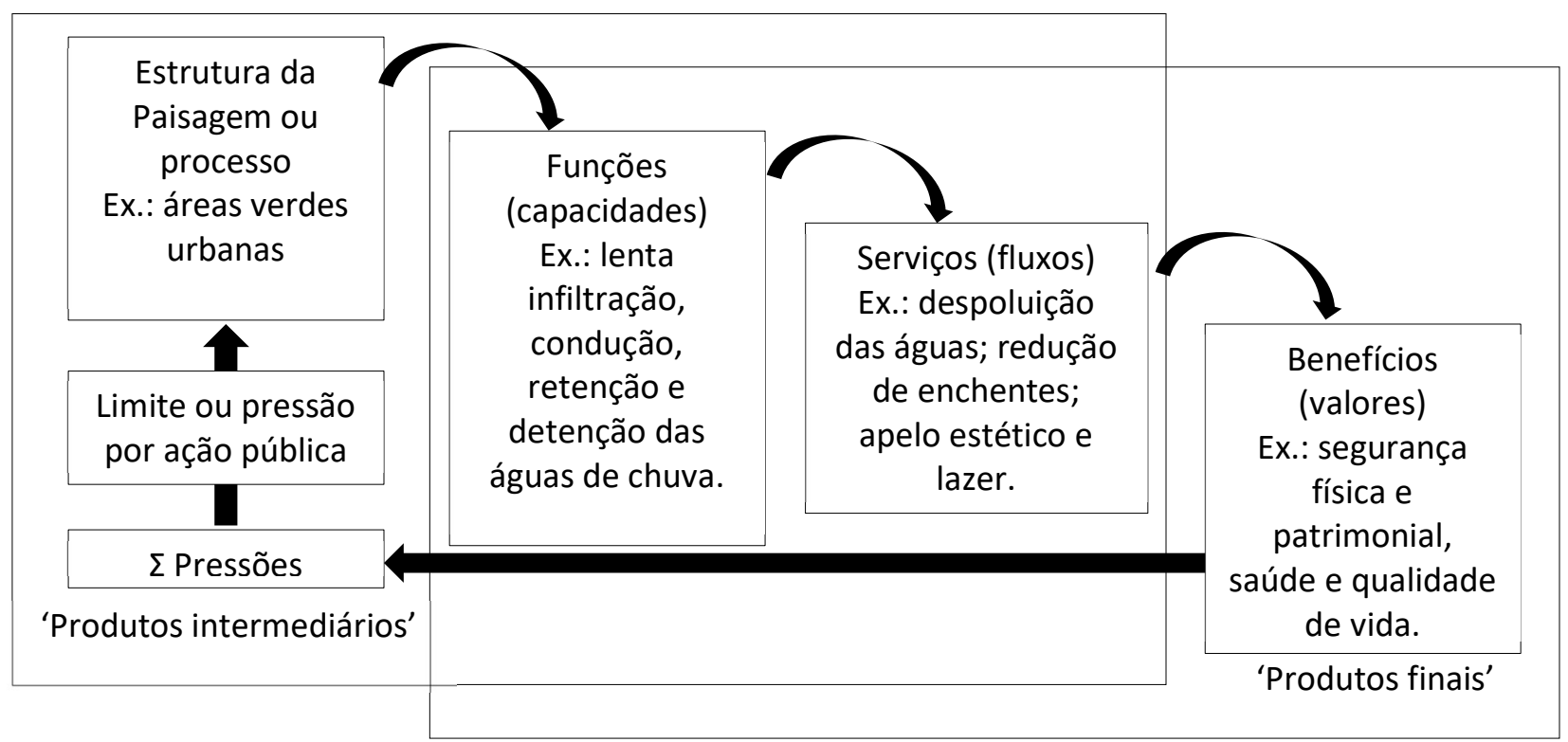

Fonte: elaborado pela autora a partir de diagrama proposto por Haines-Young e Potschin (2010).

As funções ecossistêmicas citadas nesta pesquisa serão aquelas intrínsecas aos processos hidráulicos relacionadas ao fornecimento do serviço de regulação hídrica: detenção, retenção, infiltração e condução. Quanto aos aspectos relacionados à mobilidade podemos nos perguntar: "A mobilidade seria então uma função, serviço ou benefício?"

A mobilidade, como infraestrutura, é uma função urbana. Quando relacionada às áreas verdes poderá ter seu funcionamento melhorado ou beneficiado por exemplo pela presença de arborização, que colabora com a experiencia humana de mover-se (especialmente por modos ativos). Mover-se através das áreas verdes, por exemplo a pé ou em bicicleta, possibilita às pessoas serem diretamente beneficiadas pelos SE fornecidos pelo verde, quanto à regulação microclimática, serviços culturais diversos etc., que terão efeitos positivos relacionados à 
qualidade de vida e saúde, assim como o mover-se ativamente, por si mesmo, poderá ser benéfico. A mobilidade, como substantivo, é o agente promotor do espaço para que a ação, mover, possa acontecer, sendo esta, receptora de benefícios ecossistêmicos. Portanto, consideraremos a infraestrutura como função, que pode ser beneficiada ou estar em sinergia a distintos serviços prestados pelas áreas verdes com o intuito de tornar melhorar a experiencia de mover-se. 


\section{MÉTODOS E CRITÉRIOS PARA APLICAÇÃO EM ESTUDO DE CASO}

Conforme vimos, pensar um Eixo Multifuncional pressupõe o entendimento das dinâmicas de paisagem na escala da bacia e do fundo de vale, relacionadas aos Princípios de Infraestrutura Verde destacados e complementados pelo aporte dos Serviços Ecossistêmicos. O presente capítulo apresenta os métodos complementares e critérios urbanísticos e ecológicos a serem aplicados no estudo de caso do Mandaqui, destacando os objetivos inerentes a cada item.

4.1. Metodologia para a Compartimentação da Paisagem (escala da bacia hidrográfica): compreender os processos de paisagem e o impacto urbano relacionado à regulação hídrica; indicar a potencial localização dos LIDs nos Compartimentos (complementando os aportes do Projeto Jaguaré); relacionar os LIDs ao fornecimento de outros potenciais Serviços Ecossistêmicos.

4.2 Inventário de Espaços Abertos (escala da bacia hidrográfica): identificação e caracterização dos Espaços Abertos; localização nos Compartimentos e associação aos LIDs; aptidão em fornecer distintos SE levando-se em consideração a origem ecológica e o uso do espaço.

4.3 Critérios e indicadores relacionados à acessibilidade às áreas verdes: identificação das áreas verdes acessíveis e utilizáveis pela população; cálculo do número de pessoas beneficiadas pela proximidade às áreas verdes. Acessibilidade ao eixo do Mandaqui.

Complementar ao presente capítulo, o Capítulo 5, será dedicado aos critérios para avaliação da demanda e impacto das águas (principalmente nos fundos de vale) a partir do cálculo do número de pessoas diretamente impactadas pelas chuvas de até TR100 anos. Também serão apresentados os avanços feitos durante o Projeto Jaguaré e que auxiliarão nas análises e proposições elaborados no presente trabalho.

\subsection{COMPARTIMENTOS DA PAISAGEM, INVENTÁRIO DE ESPAÇOS ABERTOS E DRENAGEM}

As cidades impactam as distintas camadas da paisagem. Clima, água, solos, relevo, vegetação e fauna são alterados a partir do momento que começamos ocupar o território. Propor soluções ao desequilíbrio ambiental causado pela pressão urbana, irá exigir a compreensão dos processos prévios e posteriores à ocupação. Como citado no Capítulo 2 da Introdução, no final dos anos 60 
o arquiteto e planejador da paisagem lan McHarg propõe o Desenho com a Natureza (Design with Nature, 1969), a partir da sobreposição de camadas de análise territorial que relacionavam o meio físico ao antropogênico, sugerindo a incorporação ao planejamento urbano e regional dos processos ecológicos das paisagens. Anterior e contemporâneo a McHarg, o geógrafo Ab’Sáber foi pioneiro no Brasil ao propor um método similar porém somente analítico, a partir do estudo geomorfológico do território que englobava três camadas temporais e físicas, inter-relacionadas: a compartimentação topográfica (ou do relevo), a estrutura superficial (ou física) e a fisiologia da paisagem (ou dos processos da paisagem), com o objetivo de compreender as relações existentes entre os fluxos de energia, água e materiais e os processos de paisagem e antropogênicos (AB'SABER, 1969). Ambos autores vem influenciando pesquisadores e profissionais nacionais e internacionais quanto ao desenvolvimento de métodos de análise espacial cada vez mais sofisticados e capazes de lidar com uma grande gama de complexidade do território.

Ahern e Steinitz nos anos 90, propõem dois dos métodos inspirados, entre outros, por McHarg e que tiveram ou ainda tem influência no planejamento de corredores verdes, e posteriormente da Infraestrutura Verde (AHERN, 1995) ${ }^{21}$ e no planejamento de paisagem em distintas escalas (STEINITZ, 1990)22. No Brasil, as influências de McHarg são citadas especialmente por NUCCI (2008), que propõe um método para a avaliação da qualidade ambiental urbana, e por Schutzer (2012) que complementa os lineamentos de $A b^{\prime}$ Saber, propondo um refinamento a partir da aproximação ecológica focada em áreas urbanas com distintos níveis de consolidação e densificação. Sendo assim, Schutzer (2012) adiciona uma camada extra de análise e relaciona o uso e ocupação do solo aos compartimentos topográficos, à estrutura superficial e à fisiologia da paisagem, definindo Compartimentos Estruturantes da Paisagem. Os Compartimentos da

\footnotetext{
${ }^{21}$ Ahern (1995) propõe o método Abiótico - Biótico - Cultural ou ABC, indicando que a camada física (abiótica) seja relacionada, quanto a seus aspectos formativos e de processo, à presença e dinâmicas da fauna e flora (biótica) e à ocupação e uso do solo (cultural).

${ }^{22}$ Steinitz (1990), propõe o Método de Estruturação para o Planejamento da Paisagem, tradução nossa para Framework Method for Landscape Planning, uma sequência de seis modelos, ou perguntas a serem respondidas para a análise e entendimento dos processos de paisagem e a toma de decisão a partir de simulação de cenários. $O$ método vem sendo adaptado a ferramentas de Geodesign, úteis em processos inter e transdisciplinares de planejamento da paisagem.
} 
Paisagem não irão coincidir necessariamente àqueles do relevo, uma vez que são o resultado de uma série de sobreposições de camadas de análise.

A aproximação à escala urbana vem sendo um dos desafios na aplicação de métodos de planejamento ecológico e da Infraestrutura Verde. Nessa escala, a abordagem proposta por Schutzer permite tanto compreender o impacto da urbanização sobre os processos naturais quanto mapear setores passíveis de regeneração a curto, médio e longo prazos, fomentando uma base de dados sobre a qual será possível desenhar estratégias e ações para melhora da qualidade urbana (SCHUTZER, 2012). O método será aplicado na escala da bacia hidrográfica, destacandose o fundo de vale do Mandaqui e receberá mais uma camada de análise composta pelos Espaços Abertos, sendo estas as áreas com maior potencial para receber a Infraestrutura Verde Urbana.

\subsection{INVENTÁRIO DE ESPAÇOS ABERTOS E IDENTIFICAÇÃO DE SERVIÇOS ECOSSISTÊMICOS}

\section{URBANOS}

O Inventário de Espaços Abertos pretende localizar, na escala da bacia, as distintas áreas com potencial em fornecer Serviços Ecossistêmicos. Como visto no Capítulo 1-Parte I, o conjunto formado por espaços verdes conectados em distintas escalas é chave para alcançarmos uma rede multifuncional com amplitude de impacto local e regional. Também discutimos a relevância de identificarmos outras tipologias de Espaços Abertos, não verdes, que atualmente realizam ou não funções infraestruturais importantes e que potencialmente poderão ser integradas ou adaptadas pela Infraestrutura Verde para conformar áreas aptas a fornecer distintos Serviços Ecossistêmicos.

Ao consideramos o princípio Multifuncionalidade, se faz necessário desenhar um panorama dos outros $\mathrm{SE}$, além daqueles relacionados à regulação hídrica, que poderiam ser prestados pelos Espaços Abertos. Para Kowarik (2013), aplicar uma perspectiva que considere as origens ecológicas das áreas verdes colaborará para o entendimento dos Serviços Ecossistêmicos prestados. A “Abordagem das Quatro Naturezas" (tradução nossa para “Four Natures Approach, KOWARIK, 2013), é uma estrutura conceitual capaz de categorizar a variedade dos espaços verdes urbanos. Essa estrutura foi aplicada inicialmente para o caso da cidade de Berlim, na Alemanha, 
e será adaptada, para o estudo de caso da tese em São Paulo. Os Espaços Abertos não verdes serão incluídos em uma categoria à parte, de acordo com as funções atuais.

Os quatro tipos de natureza diferem fundamentalmente em termos de legados paisagísticos, intervenções humanas e características ambientais, mas todos eles dependem de elementos e processos naturais acessíveis aos moradores da cidade (KOWARIK, 2013). A categoria Tipo 1- Remanescentes Florestais: abrange as áreas remanescentes do ecossistema da Mata Atlântica ou cerrado e áreas de mananciais, localizados nos extremos da cidade de São Paulo ou incorporados como fragmentos no mosaico urbano e são áreas responsáveis pelos grandes habitats urbanos. Tipo 2- Paisagem Cultural: é formada por paisagens culturais rurais, corredores ribeirinhos e bosques (principalmente encontrados nos limites sul de São Paulo); Tipo 3- Jardins e Parques Urbanos: compreende os jardins públicos e privados, os parques públicos urbanos e os cemitérios (verdes) acessíveis ao público em geral. São as áreas desenhadas para o uso das pessoas. As vezes mais e outras vezes menos exitosas, essas áreas normalmente concentram distintas atividades culturais além de poderem ser hotspots da biodiversidade. Embora originalmente não estejam englobadas a esta tipologia, algumas áreas verdes associadas ao viário poderão possuir características desse tipo. Nessa categoria são consideradas tanto áreas decorrentes de processos de transformação direta e completa do habitat original ou que foram instaladas após a destruição desses habitats; Tipo 4- Áreas em Transição: abarca os terrenos baldios e áreas abandonadas onde se nota o regresso espontâneo da natureza, podendo ter ou não a intervenção humana e incorporando tanto espécies nativas quanto ornamentais de distintos portes.

Além dessas quatro tipologias que classificam os Espaços Abertos verdes de acordo com a origem ecológica, foi identificado o conjunto de infraestruturas que compõem a rede de Espaços Abertos não vegetada, mas que exercem funções e tem potencial para serem adaptadas a fornecer outros SE. Por sua característica atualmente limitada quanto às funções desempenhadas, essa tipologia foi nomeada Tipo 5- Infraestruturas Monofuncionais. 
A definição dos potenciais SE fornecidos pelos Espaços Abertos terá como base a classificação de cobertura de solo proposta por CORINE (BURKHARD et al., 2012) ${ }^{23}$. O estudo original se baseia em macro escalas, visualizadas em 1: 100000 e propõe uma matriz de valoração utilizando a escala de 0 a 5, sendo $0=$ irrelevante e 5= relevância muito alta, para indicar a magnitude do fornecimento de um SE específico por um dado uso de solo. De forma geral, as áreas verdes urbanas são classificadas como áreas importantes para a manutenção da Integridade Ecológica (relevância variando de 1= pouca relevância a 4= muita relevância), pelo fornecimento de serviços de regulação (relevância variando entre 1= pouca relevância e 2= relevante), e pela provisão de serviços culturais associados a recreação e valores estéticos (3= media relevância). A pontuação completa pode ser visualizada no Quadro 3.

Quadro 3: Matriz de Aptidão em fornecer Serviços Ecossistêmicos de acordo com os usos de solo.

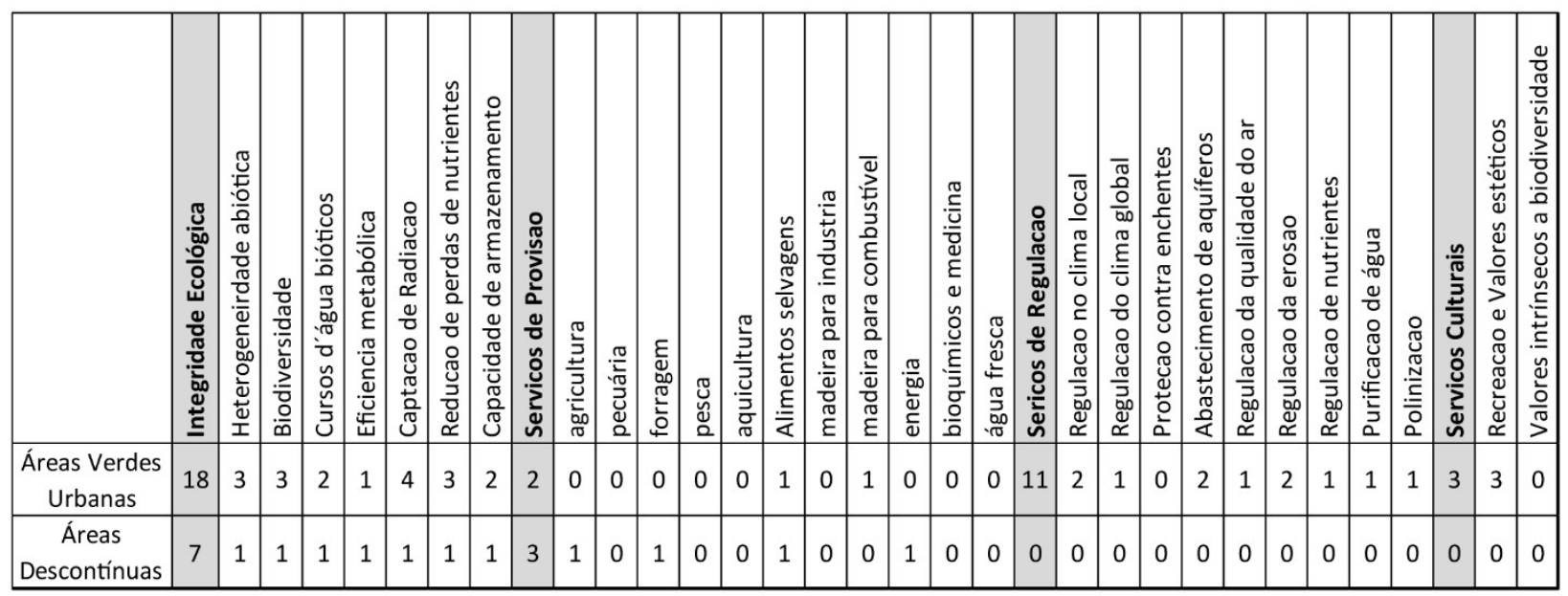

Fonte: adaptado a partir de Burkhard et al. ,(2012)(tradução nossa).

Uma vez reduzida a escala para áreas urbanas, e no nosso caso tendo a bacia hidrográfica como escala máxima abordada, a consideração dos distintos SE deverá ser adaptada. Sendo assim, foi elaborada pesquisa bibliográfica e os desmembramentos das funções hidráulicas

${ }^{23}$ Coordination of Information on the Environment ou CORINE, é um projeto atualmente coordenado pela Agencia do Meio Ambiente Europeu (EEA, sigla em inglês), e responsável por gerar uma série de base de dados geográficos para a escala europeia. Dentre eles está o levantamento de 44 categorias de uso de solo encontradas no continente. Maiores informações poderão ser encontradas em: https://www.eea.europa.eu/publications/COROlandcover Acessado em 10/01/2019. 
apresentadas no Projeto Jaguaré foram consideradas. Uma vez aplicados ao estudo de caso do Mandaqui, novas alterações poderão surgir, devido a características próprias dessa área.

O item Integridade Ecológica (ou Serviços de Suporte), foi o que sofreu menos alterações, pois poderá estar relacionado às Unidades de Conservação na área de estudo. Os Serviços de Provisão foram adaptados à escala urbana, e o item "Energia" passa a se referir tanto à concentração de biomassa nas plantas quanto ao fornecimento de energia pelos sistemas tradicionais instalados, tais como, linhão e gasoduto. Quanto à Regulação foram complementados itens referentes principalmente à regulação hídrica e microclima. Finalmente, os Serviços Culturais foram alterados segundo pesquisa bibliográfica e serão validados por observações em campo. As funções relacionadas à mobilidade foram incluídas na matriz como forma de identificar a aptidão dos Espaços Abertos em contribuir para seu melhor desempenho. O nível de relevância de fornecimento de cada serviço não será considerado por envolver uma complexidade de geração de dados que necessitaria de equipe multi, inter ou transdisciplinar para sua precisão. Os distintos SE urbanos que serão considerados na tese podem ser visualizados no Quadro 4, acompanhados das principais referências consultadas.

Quadro 4: Serviços Ecossistêmicos e Funções Urbanas a serem consideradas no estudo de caso.

\begin{tabular}{|c|c|}
\hline Habitat & Referências \\
\hline Biodiversidade & \multirow{5}{*}{ BURKHARD et al. ,2012 } \\
\hline Cursos d’água bióticos & \\
\hline Eficiência metabólica & \\
\hline Captação de Radiação & \\
\hline Redução de perdas de nutrientes & \\
\hline \multicolumn{2}{|l|}{ Serviços de Provisão } \\
\hline Agricultura urbana & GÓMEZ-BAGGETHUN; BARTON, 2013 \\
\hline Energia & BURKHARD et al. ,2012 \\
\hline Água fresca & BURKHARD et al. ,2012 \\
\hline \multicolumn{2}{|l|}{ Serviços de Regulação } \\
\hline Proteção a enchentes & $\begin{array}{l}\text { GÓMEZ-BAGGETHUN; BARTON, 2013; BURKHARD et al. ,2012; FCTH, } \\
2017\end{array}$ \\
\hline Amortização de escoamento superficial & $\begin{array}{l}\text { BOLUND; HUNHAMMAR, 1999; GÓMEZ-BAGGETHUN; BARTON, 2013; } \\
\text { FCTH, 2017; }\end{array}$ \\
\hline Recarga de aquíferos & BURKHARD et al. ,2012 \\
\hline Regulação da Qualidade do ar & BOLUND; HUNHAMMAR, 1999; BURKHARD et al. ,2012 \\
\hline Mitigação de ruído & BOLUND; HUNHAMMAR, 1999; GÓMEZ-BAGGETHUN e BARTON, 2013 \\
\hline Controle da erosão & BURKHARD et al. ,2012 \\
\hline
\end{tabular}




\begin{tabular}{|l|l|} 
Regulação de nutrientes & BURKHARD et al. ,2012 \\
\hline Descontaminação das águas & FCTH, 2017 \\
\hline Polinização e dispersão de sementes & GÓMEZ-BAGGETHUN; BARTON, 2013 \\
\hline Regulação do microclima & BOLUND; HUNHAMMAR, 1999; CATUZZO; LOMBARDO, 2011 \\
\hline \multicolumn{1}{|c|}{ Serviços Culturais } & \\
\hline $\begin{array}{l}\text { Recreação e desenvolvimento } \\
\text { cognitivo }\end{array}$ & CATUZZO; LOMBARDO, 1999; GÓMEZ-BAGGETHUN; BARTON, 2013 \\
\hline Valores estéticos & BURKHARD et al. ,2012 \\
\hline Educação ambiental & GÓMEZ-BAGGETHUN; BARTON, 2013 \\
\hline \multicolumn{1}{|c|}{ Funções de Mobilidade } & \\
\hline Transporte público & \\
\hline Transporte privado & \\
\hline Mob. ativa-bicicleta & \\
\hline Mob. ativa- caminhada & \\
\hline
\end{tabular}

Fonte: elaborado pela autora a partir de revisão bibliográfica.

\subsection{ACESSIBILIDADE ÀS ÁREAS VERDES}

A utilização de índices que parametrizem o quão sustentável ou saudável um bairro ou cidade é, vem sendo mundialmente apoiada no cálculo da metragem quadrada de áreas verdes por habitante. A utilização somente desses parâmetros vem sendo um limitante à consideração do verde urbano no planejamento ( $N U C C l, 2008)$ uma vez que não são claros ou explicitam como o dado foi gerado e/ou são baseados em estudos feitos em microclimas distintos daqueles encontrados nas cidades brasileiras (ROCHA; NUCCl, 2018). Exemplo disso é a difusão de um índice bastante utilizado no país, que afirma que cada cidade deveria contar com no mínimo 12 $\mathrm{m}^{2}$ de áreas verdes por habitante. Esse dado, presente tanto em publicações acadêmicas como em relatórios profissionais e em documentos públicos, é atribuído à Organização Mundial da Saúde (OMS) ou à Organização das Nações Unidas (ONU) ou ainda à Organização para alimentos e agricultura das Nações Unidas (FAO). A falta de precisão quanto a sua correta fonte levou Cavalheiro e Del Picchia (1992) a se corresponderem com as organizações e verificarem que nenhuma delas indica $12 \mathrm{~m}^{2}$ como índice mínimo de áreas verdes por habitante. Em publicações internacionais é comum encontrar a citação da OMS referente a $9 \mathrm{~m}^{2}$, porém em extensiva pesquisa elaborada pela autora o dado também não foi encontrado. No Brasil, a Sociedade Brasileira de Arborização Urbana (SBAU), propõe $15 \mathrm{~m}^{2}$ por habitante. Em comunicação com a 
SBAU, fomos informadas que o documento oficial, a Carta de Londrina e Ibiporã (1996), com essa informação já não está disponível para consulta, o que dificulta a compreensão do dado.

A acessibilidade não somente física, mas equitativa às áreas verdes, é um fator essencial para que as pessoas, independentemente da classe social, possam ser beneficiadas pelos serviços ecossistêmicos. Essa afirmação se relaciona diretamente à valoração da terra urbana atribuída à presença de áreas verdes, que vem tornando bairros verdes em áreas mais exclusivas da cidade ${ }^{24}$. É certo que o valor da terra é influenciado por outros fatores, como a presença de infraestruturas de mobilidade e saneamento, porém a presença de áreas verdes vem sendo demonstrada como algo pelo qual as pessoas estão dispostas a pagar mais (WU et al., 2015; HERMANN; HADDAD, 2005). Tendo em vista a geração de bairros mais exclusivos relacionados à presença do verde, as Nações Unidas definiram dentre os Objetivos Globais para o Desenvolvimento Sustentável (ODS), que até 2030 as cidades deveriam ser capazes de fornecer acesso universal a áreas verdes e espaços públicos seguros, inclusivos e acessíveis, principalmente as mulheres, crianças, idosos e pessoas com deficiências (ODS 11.7). Em São Paulo, alcançar essa meta, ou se aproximar dela, requer um trabalho conjunto com setores privados dedicados à construção, principais agentes da transformação urbana atual, e agentes públicos responsáveis pelos programas destinados à provisão de moradia à população em situação de maior vulnerabilidade.

Um indicador chave a ser considerado quanto à acessibilidade às áreas verdes é a proximidade, seja linear, calculada a partir da delimitação de área de influência (buffer), caminhável, ou calculando-se a quantidade de população que vive próxima a uma determinada área verde. Existe uma grande gama de métricas que vem sendo utilizados para determinar qual o tamanho e qualidade da área verde e a distância a ser considerada (WLO, 2016). Cavalheiro e Del Picchia (1992), definem as áreas verdes urbanas quanto à sua importância como espaços de recreação e lazer ao ar livre, integrando funções ecológicas e estéticas, e se baseiam na proposta

\footnotetext{
${ }^{24}$ Em São Paulo, dados de 2016 demonstram que dos dez bairros mais arborizados da cidade oito possuíam o metro quadrado mais caro, por exemplo, Moema era o 70 colocado em densidade arbórea (cerca de 1.260 árvores/ $\mathrm{km}^{2}$ ) e tinha o metro quadrado médio de $\mathrm{R} \$ 12.782,00$ (Properati apud EXAME, 2016)

https://exame.abril.com.br/seu-dinheiro/quer-conhecer-os-bairros-mais-caros-de-sp-conte-suas-arvores/Visitado em 09/05/2016.
} 
da cidade de Hamburgo na Alemanha (JANTZEN, F. et al. CAVALHEIRO; DEL PICCHIA, 1992, p.4)25 para sugerir um conjunto de índices que poderiam dar suporte científico ao planejamento urbano das cidades brasileiras, a fim de garantir a oferta de parques de distintas dimensões a distancias acessíveis desde a moradia das pessoas. O Nature England ${ }^{26}$ propõe o Accessible Natural Greenspace Standard (ANGSt) (NE, 2010), apresentando indicadores quanto à qualidade, quantidade e acessibilidade às áreas verdes a partir do princípio de que todos deveriam ter acesso a áreas naturais de boa qualidade próximas ao lugar onde vivem. Ambos documentos consideram o dinamismo dos indicadores e a necessidade de serem adequados ou revisados ao longo do tempo. Atualmente, Jantzen et al., (1973, apud CAVALHEIRO; DEL PICCHIA, 1992, p.4), segue sendo bastante citado, por exemplo pelo grupo de pesquisadores liderados por NUCCl, dedicados ao estudo da Qualidade Ambiental Urbana (ex.: ROCHA; NUCCI, 2018; VALASKI, 2013). No caso do NE, após 10 anos de sua proposta inicial (nos anos 1990), os indicadores foram validados e a eles incluídas diretrizes para guiar a aplicação desses critérios no planejamento de áreas verdes na Inglaterra (NE, 2010). Além dessas fontes de informação, utilizamos o Indicador Comum Europeu (tradução nossa para The European Common Indicator; Ambiente Italia Research Institute- ISTAT, 2003), que propõe uma série de indicadores baseados na Agenda $21^{27}$, um deles a respeito da oferta de espaços abertos públicos. Estes espaços incluem áreas verdes e não verdes, que são utilizadas para atividades de lazer e considera inclusive canteiros centrais ou outras áreas associadas ao viário como áreas de valor recreativo, desde que sejam assim reconhecidas pelas autoridades locais (ibid). O indicador considera que a distância de $300 \mathrm{~m}$ lineares deva ser aplicada duas vezes, a primeira a partir de áreas a partir de $5000 \mathrm{~m}^{2}$ e a segunda a partir de todas as áreas recreativas encontradas em determinado local. A validação do dado é relacionada, segundo o documento, a distintos órgãos:

\footnotetext{
${ }^{25}$ JANTZEN, F. et al. Grunflachenbedarf Parkanlagen. Hamburg: Conf.Dir.D.P.J.R.F.A., 1973, 43p.

${ }^{26}$ Natural England é um órgão público não departamental executivo responsável pela Secretaria de Estado do Meio Ambiente, Alimentação e Assuntos Rurais da Inglaterra. Para maiores informações acessar:

<https://webarchive.nationalarchives.gov.uk/20140605090110/http://www.naturalengland.org.uk/about us/defa ult.aspx> Acessado em 19/02/2019.
}

${ }^{27}$ A Agenda 21 foi discutida nas Conferência das Nações Unidas sobre Meio Ambiente e Desenvolvimento no Rio, 1992 e em Joanesburgo, 2002. 
"A Agência Europeia de Meio Ambiente (EEA), a Diretoria Geral (DG) de Política Regional e o Instituto Nacional Italiano de Estatística (ISTAT), usam o conceito "em 15 minutos de caminhada" para definir acessibilidade. Parece razoável assumir que isso corresponde a cerca de $500 \mathrm{~m}$ caminhando para pessoas idosas, o que equivale a $300 \mathrm{~m}$ em linha reta." (ISTAT, 2003, p. 185, 2003, tradução nossa).

Para aplicação no caso de estudo, os Espaços Abertos verdes foram agrupados inicialmente em distintos rangos de tamanho: 0,5 $\geq 1$ ha; $>1 \leq 5$ ha; $>5 \leq 10$ ha; $>10 \leq 20$ ha; $<20$ 100 ha; >100-500 ha e >500 ha. Posteriormente, como forma de simplificar a classificação, os tamanhos variando de $0,5 \geq 1$ ha e $>1 \leq 5$ ha foram agrupados em $0,5 \leq 5$ ha e os rangos $>10 \leq 20$ ha e $<20 \leq 100$ ha, foram agrupados em $>10 \leq 100$, por compartilharem o mesmo indicador de distância. O Quadro 5 apresenta o resultado dessas interações, em negrito (a aplicação no estudo de caso é descrita na -Parte II- Subcapítulo 4.3 e o Anexo 2 disponibiliza os indicadores originais de cada autor).

Quadro 5: Indicadores de Acessibilidade às áreas verdes.

\begin{tabular}{|c|c|c|}
\hline Área (ha) & Distância & Referência \\
\hline$>0.5 \leq 1 \mathrm{ha}$ & $300 \mathrm{~m}$ & ISTAT, 2003 \\
\hline$>1 \mathrm{ha} \leq 5 \mathrm{ha}$ & $300 \mathrm{~m}$ & Adaptado de NE, 2010; indicador 2-20 ha \\
\hline $2-20$ ha & $300 m$ & $N E, 2010$ \\
\hline$>5 \leq 10$ ha & $1000 \mathrm{~m}$ & $\begin{array}{c}\text { Adaptado de JANTZEN, F. et al., 1973, apud CAVALHEIRO e } \\
\text { DEL PICCHIA, 1992, p. 4.; indicador } 10 \text { ha }\end{array}$ \\
\hline$>10 \leq 20$ ha & $2000 \mathrm{~m}$ & Adaptado de NE, 2010, indicador 20-100 ha \\
\hline$<20 \leq 100$ ha & $2000 \mathrm{~m}$ & $N E, 2010$ \\
\hline$>100 \leq 500$ ha & $5000 \mathrm{~m}$ & $N E, 2010$ \\
\hline 100 ha & $1200 \mathrm{~m}$ & $\begin{array}{c}\text { JANTZEN, F. et al., 1973, apud CAVALHEIRO e DEL PICCHIA, } \\
\text { 1992, p. } 4 .\end{array}$ \\
\hline 200 ha com água & $\begin{array}{c}\text { Localizado em } \\
\text { qualquer parte da } \\
\text { cidade }\end{array}$ & $\begin{array}{c}\text { JANTZEN, F. et al., 1973, apud CAVALHEIRO e DEL PICCHIA, } \\
\text { 1992, p. } 4 .\end{array}$ \\
\hline$>500$ ha & $10.000 \mathrm{~m}$ & NE, 2010 \\
\hline
\end{tabular}

Fonte: elaborado pela autora. 


\section{REGULAÇÃO HÍDRICA: ESCALAS DE IMPACTO E ESTRATÉGIAS LID}

Estima-se que em áreas vegetadas por volta de $5-15 \%$ da água de chuva escoe superficialmente e o restante seja absorvido pela vegetação e solos para abastecer os aquíferos e/ ou regressa ao ambiente através de processos de evapotranspiração (BOLUND; HUNHAMMAR, 1999). Em áreas urbanas intensamente pavimentadas, há uma inversão desses valores e o escoamento superficial pode atingir taxas superiores a 60\% (BERNATZKY, $1983^{28}$ apud BOLUND; HUNHAMMAR, 1999, p. 297), elevando o impacto nos fundos de vale. O reflexo dessa alteração física no uso e ocupação do solo é evidenciada pelas alterações no hidrograma a montante e jusante dos rios e córregos. No curso originalmente sinuoso dos corpos d'água, o amortecimento das enchentes ocorre a montante, nas porções superiores e medias enquanto na situação retificada e canalizada, a alteração drástica dessa condição resulta na falta de amortecimento dos volumes de água dos trechos médio e superior causando grande impacto a jusante e maiores e mais constantes inundações (Figura 14).

Figura 14: Diferenças no amortecimento do hidrograma de enchente em função de modificações no percurso do curso de água.

hidrograma montante

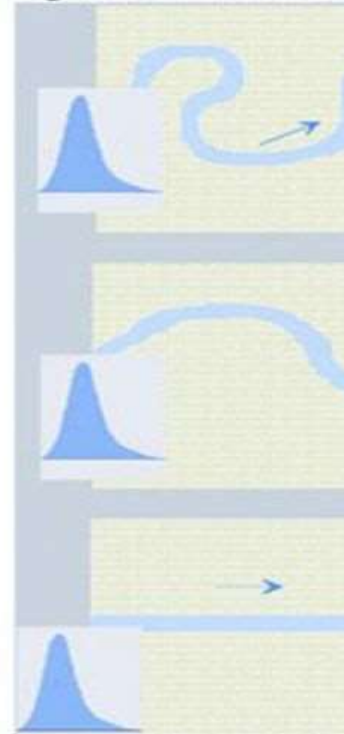

Fonte: Rio de Janeiro (Estado), (2001, p. 57). hidrograma jusante

retificação
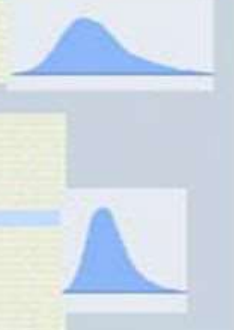

\footnotetext{
28 BERNATZKY, A. The effects of trees on the urban climate. In: Trees in the 21st Century. Academic Publishers,
} Berkhamster. Based on the first International Arbocultural Conference, pp. 59-76, 1983. 
Além da retificação dos rios e córregos, São Paulo vem sofrendo as consequências das mudanças climáticas globais anunciadas pelo Painel Intergovernamental sobre Mudanças Climáticas (IPCC), alternando períodos de seca aos de chuvas em eventos cada vez mais intensos. Localmente, o aumento da pluviosidade na cidade de São Paulo entre 1933 e 2010, decorrente do aquecimento das áreas urbanas e do oceano, é estimada em cerca de 80\% (PIVETTA, 2012). Os dados apresentados na Gráfico 1, relacionam a média de chuva por períodos de 8 ou 10 anos, entre 1933 e 2019. A partir dos anos 1980, verifica-se que os volumes de chuva médios anuais podem ultrapassar $1800 \mathrm{~mm}$ chegando a extremos 2236mm em 1983. Os valores médios por década passam a girar em torno de $1600 \mathrm{~mm}$, cerca de $400 \mathrm{~mm}$ a mais do que as médias calculadas até o final da década de 40 (PMSP, 2019).

Gráfico 1: Pluviosidade média entre 1933 e 2019 na cidade de São Paulo.

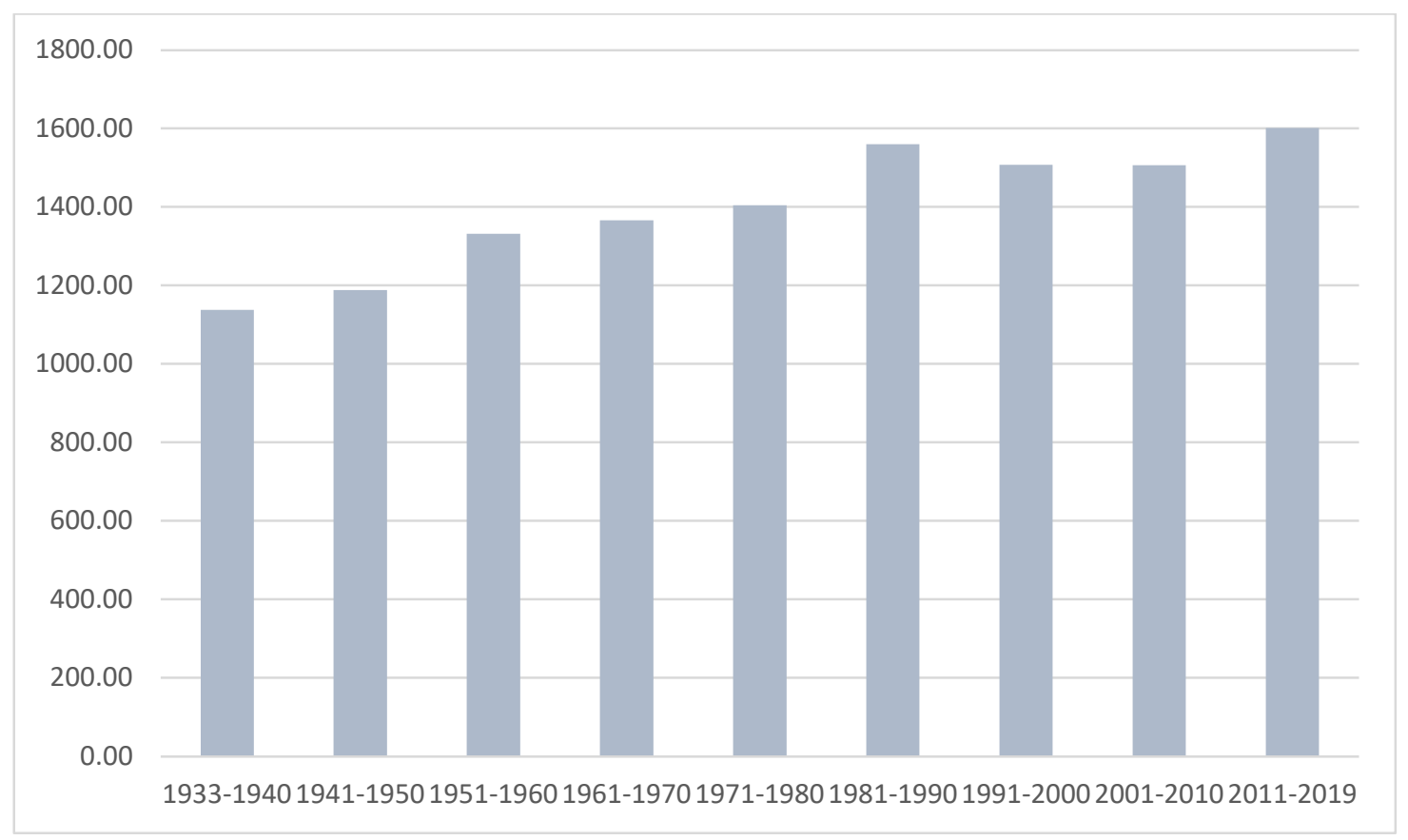

Fonte: elaborado pela autora a partir dos dados de Precipitação Pluviométrica do Município de São Paulo- 19332019 (PMSP, 2019).

A fim de 'combater as enchentes', cada vez mais frequentes, como consequência dos processos e fenômenos descritos acima, reservatórios de grande capacidade, os piscinões, passaram a ganhar destaque nas obras hidráulicas da metrópole paulista desde sua primeira instalação nos anos 90. O monitoramento, limpeza e segurança dos reservatórios é de 
reponsabilidade de cada município onde está instalado, na cidade de São Paulo já são 20 unidades (DAEE, 2019). Essas estruturas de dimensões gigantescas tanto perimetrais como de profundidade, são normalmente desenhadas como grandes depressões abertas de concreto com capacidades que variam, em zona urbana, entre 25.000 e $200.000 \mathrm{~m}^{3}$, podendo chegar a extremos de $800.000 \mathrm{~m}^{3}$ de água armazenada em áreas industriais ${ }^{29}$ (ibid). Por seu dimensionamento focado nos eventos mais extremos de chuva, os piscinões passam a maior parte do ano ociosos, ocupando áreas que poderiam receber outros usos e funções urbanas. Outro ponto relevante é o acúmulo de resíduos sólidos carreados pelas chuvas, um problema tanto ao funcionamento dos reservatórios quanto à salubridade urbana e deve ser solucionado por medidas não estruturais associadas à drenagem (FCTH, 2017).

Segundo o DAEE, os piscinões cumprem o papel das várzeas dos rios (DAEE, 2018). Essa afirmação reflete um pensamento ainda bastante restrito quanto às funções que uma várzea pode desempenhar e os serviços e benefícios ecossistêmicos associados a ela, tornando simplória a substituição da várzea natural por esta artificial. É compreensível que em áreas urbanas consolidadas como São Paulo, o espaço conquistado das várzeas não possa ser devolvido integralmente à paisagem, tampouco os pavimentos e construções removidos completamente a fim de retomarmos as dinâmicas ecossistêmicas tal qual eram antes da presença das cidades. A integração da Infraestrutura Verde às cinzas busca responder a este desafio e propõe uma discussão válida que parte da viabilidade de um desenho que possa associar a capacidade de armazenamento de grandes volumes ao cumprimento de outras funções urbanas e ecológicas a partir de uma abordagem na escala da bacia. Além disso, a dispersão de dispositivos na bacia irá contribuir para a amortização dos grandes volumes que chegam às áreas mais baixas da bacia.

\subsection{APLICAÇÃO DA INFRAESTRUTURA VERDE NO PROJETO JAGUARÉ30}

Conforme mencionado no Capítulo 6 da Introdução, o Projeto Jaguaré focou na aplicação de técnicas de Infraestrutura Verde dedicadas ao manejo sustentável das águas de chuva

\footnotetext{
29 Piscinão Petrobras em Mauá (DAEE, 2019).

${ }^{30}$ Este subcapítulo é baseado nas contribuições da doutoranda ao Projeto Jaguaré, publicadas no volume 2 tomo 3 e no volume 3, tomo 3 (FCTH, 2017), e artigos complementares. Além disso, foram adicionadas discussões e referencias complementares feitas pela autora.
} 
(identificados como LID), destacando-se quanto aos princípios: Integração Verde-Cinza e Múltiplas escalas (bacia e sub-bacia piloto; micro e macrodrenagens). No presente capítulo serão apresentadas as funções hidráulicas priorizadas, as tecnologias de baixo impacto discutidas durante o Projeto, tanto para micro quanto macrodrenagem, e sua integração ou adaptação às infraestruturas cinzas.

Uma das primeiras análises feitas no Projeto foi a identificação dos distintos Espaços Abertos (conforme definido na Parte I- Subcapitulo 1.2), classificados como: praças; áreas verdes associadas ao viário, residencial, comercial ou industrial; áreas verdes (parques e grandes áreas verdes tais como cemitérios e glebas ainda sem desenvolvimentos imobiliários); linhão (rede de alta tensão); e áreas pavimentadas (grandes estacionamentos comerciais e industriais). Sequencialmente foi elaborado um mapa relacionando a declividade do terreno, dividida em intervalos: $>0=5 \%$; $>5=10 \% ;>10=20 \%$; $>20=30 \%$ e > 30\%, e a posição topográfica em planície aluvial ou não fora dela foi identificada. Por serem muito pouco expressivas, as áreas de risco geológico foram excluídas, mas os pontos contaminados foram espacializados a fim de orientar a instalação de LIDs nessas áreas.

O terceiro passo contou com a definição das tipologias de dispositivos de baixo impacto que melhor pudessem de adaptar ao contexto das bacias hidrográficas da Região Metropolitana de São Paulo, pautados em quatro funções hidráulicas: detenção, retenção, infiltração e condução. Considerou-se que a função biorretenção seja realizada por todos os tipos de LIDs, e o tratamento das águas corresponda aos sistemas capazes de melhorar a qualidade dos volumes contaminados por cargas de esgoto.

A função detenção está associada a tecnologias que contribuem para a desaceleração do fluxo das águas pluviais, aliviando a pressão no sistema de drenagem a jusante. A água é armazenada em reservatórios localizados off-line, ou seja, fora do curso d'água, e liberada lentamente em um período de 24 horas normalmente, para que o dispositivo esteja vazio quando outras chuvas ocorrerem (FCTH, 2017). Essa função é comumente encontrada em tecnologias tradicionais rígidas tais como, piscinões, piscininhas associadas a empreendimentos e cisternas. Nesses casos, pelos materiais construtivos que empregam e por possuírem um tempo de detenção relativamente curto, não são eficazes quanto a remoção de matéria sólida, particulada ou de 
contaminantes. Essas características, no entanto, estão presentes nas alternativas de reservatórios de grande escala vegetados e nos dispositivos de baixo impacto em micro escala como por exemplo, Jardins de Chuva, Canteiros Pluviais, Tetos Verdes e Pavimentos Permeáveis com área de reservação de água (FCTH, 2017). No caso dos Pavimentos Permeáveis, a câmara de britas com distintas gramaturas, localizada na área de detenção das águas, colabora para a formação de um filtro biológico que irá colaborar para a remoção de alguns contaminantes.

Com princípios similares à detenção, a função retenção também se baseia no amortecimento dos volumes de água a jusante. Sua principal diferença se refere à localização das estruturas que retém as águas, ao longo do curso dos rios ou córregos, in-line, sendo adaptadas a distintas declividades, ou dispostas como lagos e lagoas, exigindo grandes áreas inundáveis (FCTH, 2017). Nessas tipologias há uma constantemente lâmina d’água na superfície e quando vegetadas, os processos de biorretenção e tratamento das águas são favorecidos pela presença das plantas que potencializam a absorção e decomposição da matéria orgânica e a dissolução de poluentes. Essas características também colaboram para valores estéticos da paisagem e suportam 0 aparecimento de fauna aquática e terrestre (ibid). No Jaguaré, a versão in-line foi proposta ao longo de alguns córregos com o objetivo de manter-se o fluxo contínuo de água e evitar a proliferação de vetores. Os processos envolvidos nas duas tipologias podem ser observados na Figura 15.

Outra função bastante explorada nos LIDs é sua capacidade de infiltração lenta das águas, retomando processos que contribuem tanto para a recarga dos aquíferos quanto para o abatimento de cargas de poluição difusa, com eficiência que pode chegar próxima aos $90 \%$ (MOURA, 2013). A capacidade infiltrante deve ser verificada de acordo às condições geotécnicas e de solo da área, respeitando-se uma distância mínima entre o fundo da tecnologia e o lençol freático de $60 \mathrm{~cm}$, a inclinação máxima do relevo máxima a 5\% e uma distância de segurança a partir de taludes íngremes (FCTH, 2017). Para aumentar a capacidade filtrante, durante a infiltração, é possível selecionar vegetação e substratos mais adequados ao tratamento de determinados contaminantes. No caso de áreas com histórico de contaminação industrial não é recomendado o uso das técnicas infiltrantes a fim de evitar que a poluição se direcione aos aquíferos (ibid), com a salvaguarda de projetos específicos de bioremediação de solos. 
Figura 15: Reservatórios de retenção e detenção, respectivamente in-line e off-line.

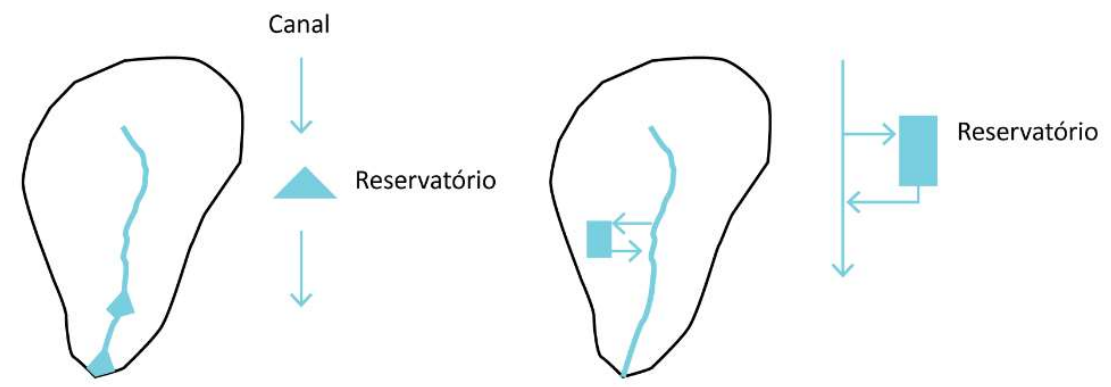

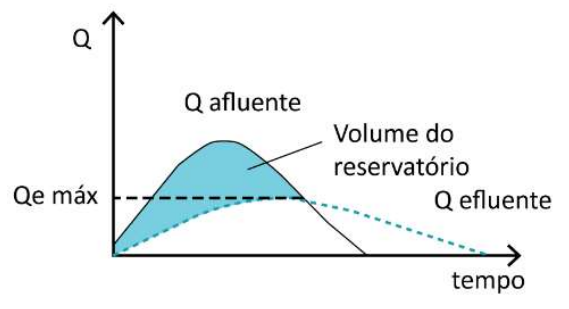

Reservatório IN-LINE

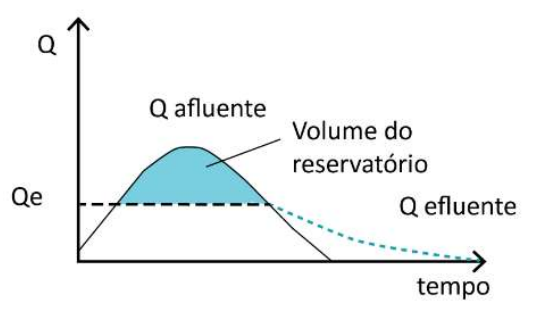

Reservatório OFF-LINE

Fonte: elaborado pela autora a partir de FCTH (2017).

Quanto à integração verde-cinza, os LIDs infiltrantes poderão ser acoplados aos sistemas de drenagem tradicionais de modo a evitar o carreamento da contaminação difusa e do material particulado pelos tubos de drenagem, favorecendo o funcionamento do sistema e da qualidade das águas a jusante. Tubos extravasadores também poderão ser instalados para o manejo de picos de fluxo (CORMIER; PELLEGRINO, 2008). A fim de garantir a operacionalidade dessas tecnologias a longo prazo, recomenda-se a instalação de mecanismos para o abate dos sólidos suspensos, como faixas de grama, filtros de areia etc. anteriores aos dispositivos (FCTH, 2017). As tecnologias selecionadas pelo Projeto que integram esta função são: Jardim de Chuva, Canteiro Pluvial e Biovaleta (quando instalada em áreas de baixa declividade, até $5 \%$, de tal forma a manter a condução das águas, porém a menor velocidade).

Finalmente, a função condução é a responsável por distribuir o fluxo do escoamento superficial a outros pontos da bacia, atuando por gravidade e de forma a amortecer os volumes e a velocidade das águas a jusante. Para estas tecnologias, sugere-se que seja estimulada uma certa capilaridade do sistema, ou seja, a priorização da instalação de canais de drenagem vegetados de menores dimensões e distribuídos por toda bacia, ao invés de poucos e concretados 
canais impermeáveis. Dessa forma a contribuição dos LIDs condutores para o alívio da pressão à jusante será maior (FCTH, 2017). Os dispositivos condutores também irão contribuir para a detenção e a infiltração das águas. Ainda que possuam menor eficiência quanto a estas funções, a presença da vegetação cumpre o papel de atenuar os poluentes difusos superficiais (ibid).

\subsection{TÉCNICAS DE CONTROLE IN SITU}

Às funções hidrológicas definidas seguiu-se a escolha e adequação das tipologias LID a partir da consulta a duas publicações principais: "Low Impact Development: a design manual for the urban áreas", (UACDC, 2010) e "Storm Water Management Model Reference Manual. Volume II" (ROSSMAN; HUBER, 2016). O segundo manual é a base de referência para o PCSWMM, software utilizado pela equipe para realizar as modelagens hidráulicas da bacia. Como resultado foram selecionados e detalhados os seguintes dispositivos, dedicados à microdrenagem: Pavimento Permeável (PP), Jardim de Chuva (JC), Canteiro Pluvial (CP) e Biovaleta (BV). Para a escala dos edifícios foram selecionados: Tetos Verdes (TV) e Calhas Desconectadas (CD) relacionadas a cisternas ou jardins de chuva. Cada dispositivo foi desenhado em corte e acompanhado de um fluxograma de instalação que o relaciona à declividade do terreno e à localização na planície aluvial ou fora dela. Também foram descritas as distintas camadas, superficiais e subterrâneas, às tecnologias, a fim de dar o respaldo necessário para calibrar os modelos hidráulicos no software. ${ }^{31}$ As Figuras 16 e 17 apresentam o exemplo para a biovaleta e o Quadro 6 sintetiza as características de cada LID relacionados aos Espaços Abertos onde melhor se adaptam, suas metas de instalação, funções e diferenciais e restrições.

\footnotetext{
${ }^{31}$ A tabela completa com os dados está disponível em FCTH, (2017).
} 
Figura 16: Esquema para a construção de biovaleta.

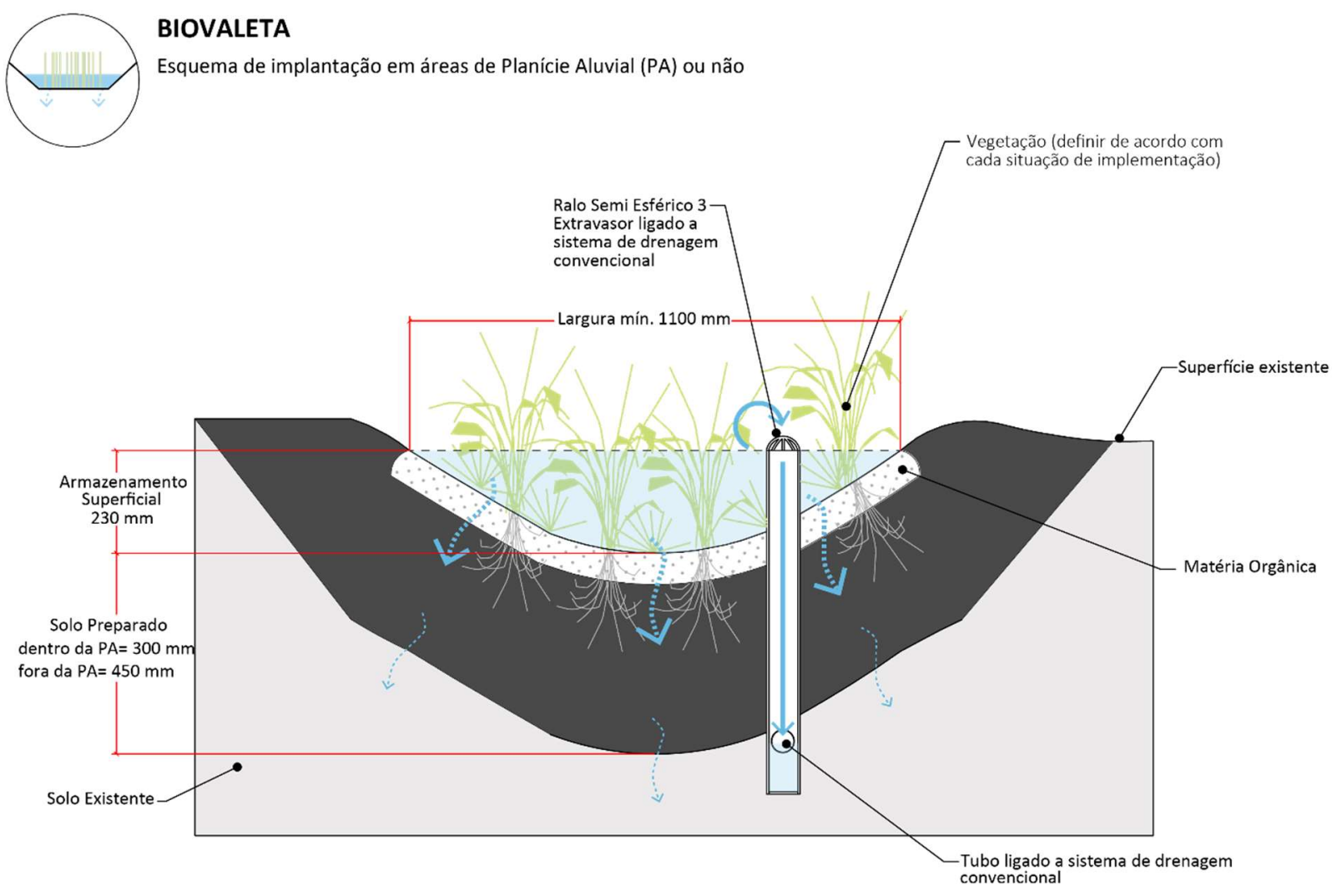

Fonte: FCTH, (2017, vol. 2 tomo 3, p. 57).

Figura 17: Fluxograma para orientar a instalação da biovaleta.

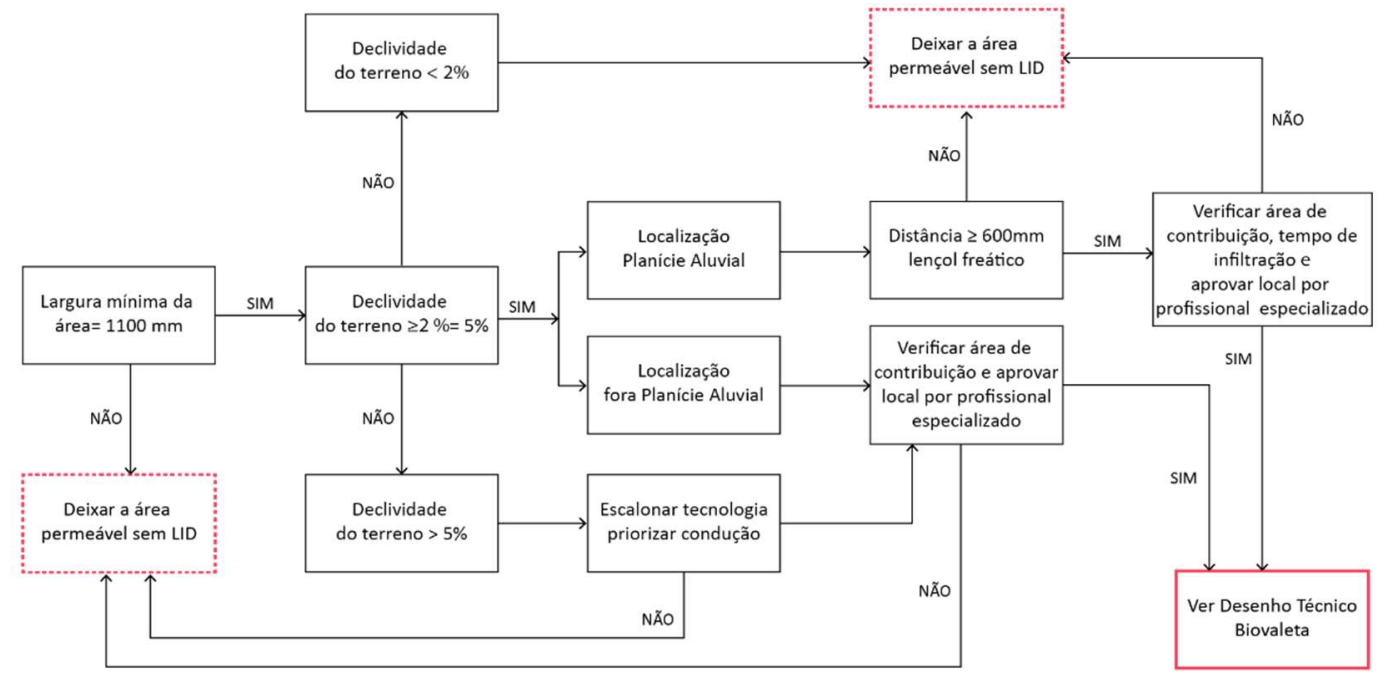

Fonte: FCTH (2017, vol. 2 tomo 3, p. 56). 
Quadro 6: Tipologias LID associadas a funções, localização na bacia, dimensão e diferencial e restrição.

\begin{tabular}{|c|c|c|c|c|c|c|c|c|}
\hline \multirow[b]{2}{*}{ LID } & \multicolumn{5}{|c|}{ Função } & \multirow[b]{2}{*}{$\begin{array}{l}\text { Localização na Bacia } \\
\text { e declividade }\end{array}$} & \multirow[b]{2}{*}{ Dimensão } & \multirow[b]{2}{*}{ Diferencial e Restrição } \\
\hline & 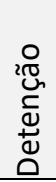 & 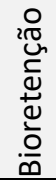 & 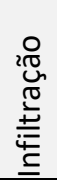 & 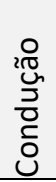 & 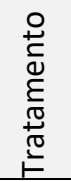 & & & \\
\hline 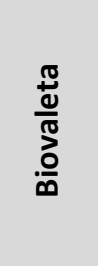 & $\begin{array}{l}+ \\
-\end{array}$ & + & + & + & & $\begin{array}{l}\geq 2 \% \leq 5 \% \text { fora da } \mathrm{PA} ; \\
\text { PA ver restrição; }>5 \% \\
\text { escalonar e manter } \\
5 \% \text { de inclinação } \\
\text { máxima na } \\
\text { tecnologia. }\end{array}$ & $\begin{array}{l}\text { L mín. 1,10 } \\
\text { m; C mín. } \\
\text { 1,00 m }\end{array}$ & $\begin{array}{l}\text { D_Instalada em áreas lineares } \\
\text { de Encostas e Topos de Morro; } \\
\text { extravasores ao sistema } \\
\text { tradicional; } \mathbf{R}_{\text {_PA }} \text { o lençol } \\
\text { freático deverá estar a pelo } \\
\text { menos } 60 \mathrm{~cm} \text { a partir da base. }\end{array}$ \\
\hline 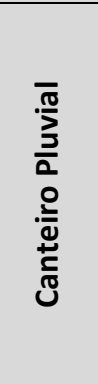 & $\begin{array}{l}+ \\
-\end{array}$ & + & + & + & & $\begin{array}{l}\geq 2 \% \leq 5 \% \text { fora da } \\
\text { PA; }>5 \% \text { escalonar e } \\
\text { manter } 2 \% \text { de } \\
\text { inclinação máxima } \\
\text { da tecnologia. }\end{array}$ & $\begin{array}{l}\text { L mín. 1,10 } \\
\text { m; C mín. } \\
\text { 1,00 m e } \\
\text { máximo 5,00 } \\
\text { m }\end{array}$ & $\begin{array}{l}\text { D_Instalada áreas lineares } \\
\text { estreitas em Encostas e Topos } \\
\text { de morro; dupla área de } \\
\text { armazenamento; dreno } \\
\text { conectado ao sistema } \\
\text { tradicional; R_PA o lençol } \\
\text { freático deverá estar a pelo } \\
\text { menos } 60 \mathrm{~cm} \text { de profundidade } \\
\text { a partir da base. }\end{array}$ \\
\hline 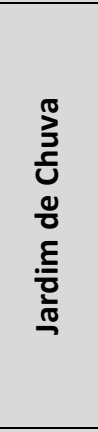 & + & + & + & & & $\begin{array}{l}\geq 2 \% \text { a } 5 \% \text { fora da } \\
\text { PA; PA ver restrição; } \\
>5 \% \text { de declividade } \\
\text { do terreno, } \\
\text { escalonada em } \\
\text { jardins de chuva } \\
\text { sequenciais }\end{array}$ & $\begin{array}{l}\text { Área mínima } \\
\text { de } 2 \mathrm{~m}^{2}\end{array}$ & $\begin{array}{l}\text { D_Adaptável ao local de } \\
\text { instalação; extravasores ao } \\
\text { sistema tradicional; pode ser } \\
\text { conectada a calhas R_PA o } \\
\text { lençol freático a } 60 \mathrm{~cm} \text { de } \\
\text { profundidade a partir da base; } \\
\text { escalonada, verificar volumes } \\
\text { máximos de armazenamento; } \\
\text { em edifícios, verificar distancias } \\
\text { seguras às construções. }\end{array}$ \\
\hline 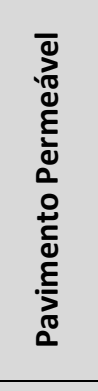 & + & & & & & $\begin{array}{l}\text { Declividade máxima } \\
\text { de } 5 \% \text { dentro ou fora } \\
\text { da Planície Aluvial. }\end{array}$ & Não se aplica & $\begin{array}{l}\text { D_Instalação em áreas de } \\
\text { distintas dimensões; sistemas } \\
\text { de blocos permeáveis ou asfalto } \\
\text { poroso; } \mathbf{R} \text { _Somente para vias } \\
\text { de tráfego leve, áreas pedonais } \\
\text { e estacionamentos de veículos } \\
\text { leves. Perda de cerca de } 85 \% \text { de } \\
\text { permeabilidade em } \\
\text { aproximadamente } 1 \text { ano. }\end{array}$ \\
\hline 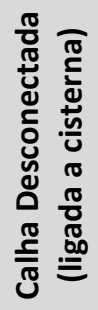 & + & & & & & Não se aplica & $\begin{array}{c}\text { De acordo } \\
\text { com a área } \\
\text { de } \\
\text { contribuição } \\
\text { do telhado }\end{array}$ & $\begin{array}{l}\text { D_Instalada em edifícios de } \\
\text { distintas alturas e usos; } \\
\text { R_Prever sistema de } \\
\text { esvaziamento ou destinação a } \\
\text { reservatório de utilização de } \\
\text { água pluvial. }\end{array}$ \\
\hline
\end{tabular}




\begin{tabular}{|c|c|c|c|c|c|c|}
\hline 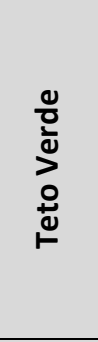 & + & + & & Não se aplica & Não se aplica & $\begin{array}{c}\text { D_Instalada em tetos de } \\
\text { distintos tamanhos, } \\
\text { potencializa usos de lazer; } \\
\text { poderá ser associado a } \\
\text { cisternas para utilização de } \\
\text { águas pluviais; R_Lajes planas } \\
\text { são melhores adaptáveis ao } \\
\text { sistema. }\end{array}$ \\
\hline 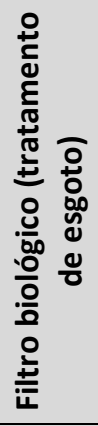 & & & + & Não se aplica & $\begin{array}{c}\text { L mín. interna } \\
\text { de } 1,50 \text { m e } \\
\text { Comprimento } \\
\text { variável }\end{array}$ & $\begin{array}{c}\text { D_Integrado à paisagem, } \\
\text { contribui para revitalização e } \\
\text { uso do espaço público; } \\
\text { R_Cargas industriais ou grandes } \\
\text { volumes de esgoto doméstico } \\
\text { poderão saturar o sistema; } \\
\text { indica-se instalação de bacia de } \\
\text { sedimentação de sólidos a } \\
\text { montante da entrada do } \\
\text { sistema. }\end{array}$ \\
\hline 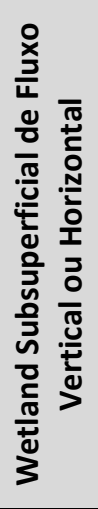 & + & & + & $\begin{array}{l}\text { Planície aluvial, áreas } \\
\text { livres de inundação } \\
\text { próximas a PA e } \\
\text { encostas } \\
\text { considerando } \\
\text { restrições. }\end{array}$ & $\begin{array}{c}\text { Variável, com } \\
\text { profundidade } \\
\text { entre } 0,8 \text { e } 1 \\
\text { m }\end{array}$ & $\begin{array}{l}\text { D_Integrado à paisagem, } \\
\text { contribui para a revitalização e } \\
\text { uso dos espaços públicos; o } \\
\text { fluxo subsuperficial minimiza a } \\
\text { proliferação de vetores; } \\
\text { R_Resíduos sólidos podem } \\
\text { comprometer o sistema; } \\
\text { sugere-se instalação de } \\
\text { mecanismos de captação de } \\
\text { resíduos anterior a entrada do } \\
\text { sistema; necessita grandes } \\
\text { áreas para ser instalado }\end{array}$ \\
\hline
\end{tabular}

Fonte: elaborado pela autora a partir dos dados apresentados em FCTH (2017).

A manutenção dos LIDs varia de acordo à tipologia. No geral, as estruturas vegetadas necessitarão de podas e limpezas para remoção de resíduos sólidos e espécies invasoras, reposição eventual de alguma planta danificada e limpeza anual de drenos. No caso do pavimento permeável, haverá a necessidade de remoção da colmatação, com periodicidade dependente do volume de material particulado carreado pelas águas até o sistema (FCTH, 2017). A responsabilidade pela manutenção dessas estruturas ainda é bastante discutida e variam de formatos de contratação de empresas privadas pelo órgão público a estratégias de envolvimento da comunidade nos cuidados com estas áreas.

Uma vez definidas as tecnologias LID para microdrenagem foram relacionadas à potencial área que poderiam ocupar em cada um dos Espaços Abertos a partir de simulações de desenho. 
Essas bases foram utilizadas posteriormente para a elaboração de simulações quanto à eficiência do sistema na escala da bacia, a partir de processos de modelagem no software PCSWMM. Atenção especial foi dada ao sistema viário, pois mesmo em uma bacia com grandes Espaços Abertos verdes como a do Jaguaré, estas são as áreas públicas com maior potencial de alteração. Sendo assim, foram definidas taxas de instalação das tecnologias levando-se em conta a largura das vias, até $7 \mathrm{~m},>7-12 \mathrm{~m}$ e >12-18 m. Essa simulação só foi possível porque a subprefeitura do Butantã, onde praticamente toda a bacia se insere, havia feito o levantamento dos dados previamente ao Projeto, sendo possível calcular a contribuição dessas tecnologias para a remoção de cargas difusas. Em outras bacias de São Paulo a largura das vias não está disponível ${ }^{32}$. Ainda assim, as diretrizes e cálculos elaborados pelo Projeto Jaguaré poderão ser utilizados como parâmetros para a aplicação dos LIDs em outros lugares da cidade.

\subsection{UMA NOVA GERAÇÃO DE RESERVATÓRIOS}

No Jaguaré foram propostos reservatórios subterrâneos e abertos de grande capacidade, para o amortecimento das chuvas de até TR 100 anos. Quando subterrâneos, passaram a fornecer espaço para que outros usos urbanos pudessem ocorrer em praças instaladas sobre estas estruturas e, quando abertos, foram desenhados a partir da elaboração de modelos computacionais paramétricos que mimetizam a morfologia natural dos ecossistemas lóticos ${ }^{33}$ a fim de se adaptarem tanto às vazões de base, em períodos secos, quanto a grandes volumes de chuva (MARQUES et al., 2018) denominando assim uma nova geração de reservatórios, in e offline, anomatosados para São Paulo (MOURA, et al., 2018). Essas novas formas da paisagem são capazes de retomar distintas funções das várzeas, contribuindo por exemplo para a melhora da biodiversidade, a qualidade das águas e o apelo estético. Funcionam também como demonstradores das dinâmicas das águas, e ao revelar estes processos contribui para que a

\footnotetext{
${ }^{32}$ As prefeituras regionais da Casa Verde/ Cachoeirinha e Santana/ Tucuruvi, responsáveis pela gestão das áreas da bacia do Mandaqui, foram contatadas por telefone e pessoalmente no ano de 2018 pela doutoranda e não possuem o levantamento das larguras das vias dos distritos que gerem.

${ }^{33} \mathrm{Em}$ ecologia, os sistemas lóticos são aqueles referentes ao ambiente aquático que mantém suas águas em movimento, por exemplo, rios, nascentes e córregos.
} 
população seja conscientizada a respeito dos distúrbios ecológicos e de como pode ser possível conviver com eles (Figura 18).

Figura 18: Esquema das distintas gerações de piscinões em São Paulo.

Temporada de estiagem

Temporada de chuvas

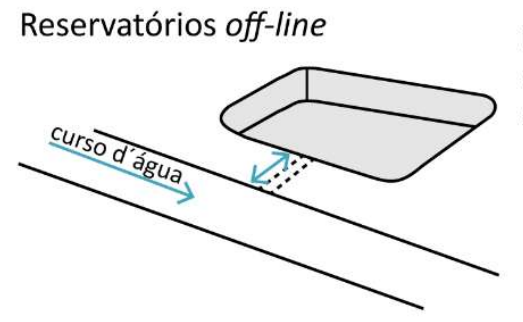

Piscinão aberto de concreto

Obsoleto durante estiagem

Cheio em eventos mais intensos

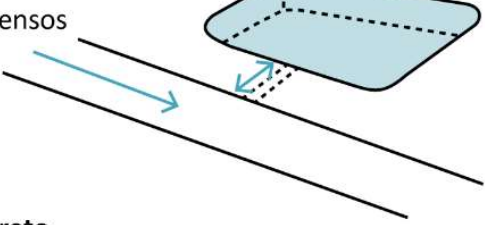

Piscinão fechado de concreto

Outros usos do teto

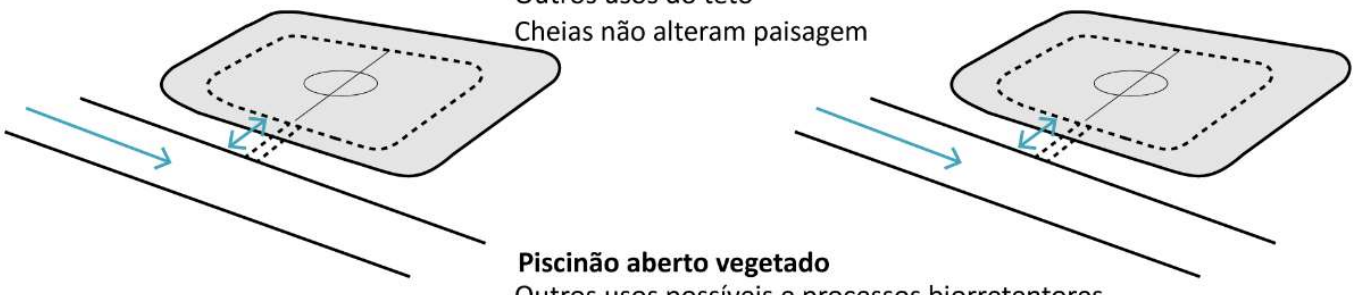

Outros usos possíveis e processos biorretentores

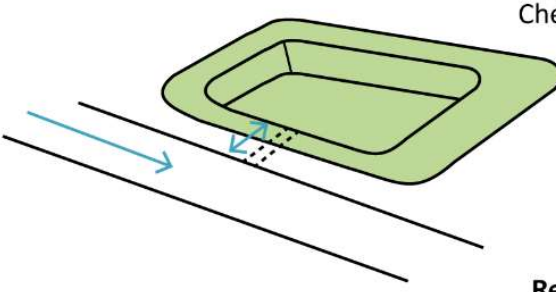

Cheio em eventos mais intensos

Reservatórios in-line

Reservatório anomatosado

Vários pequenos reservatórios vegetados

Outros usos possíveis da várzea seca

Revelação dos processos da paisagemem diferentes estados de cheia
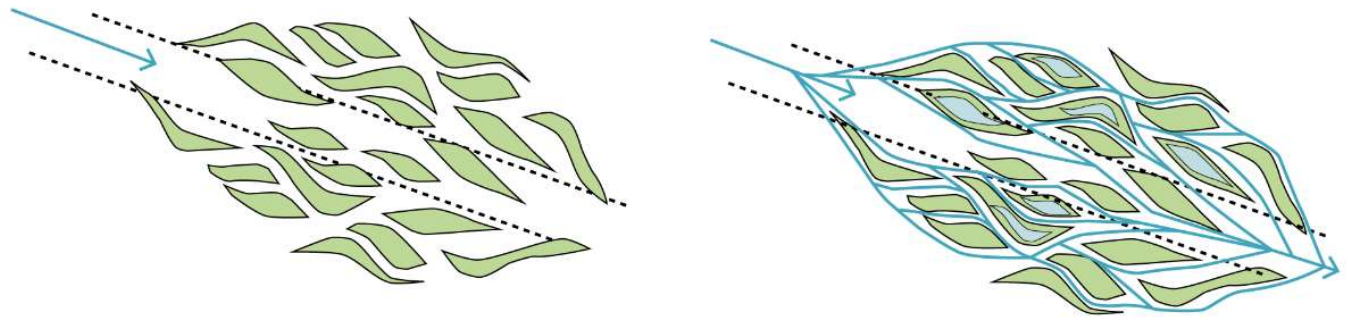

Nível de água no canal principal

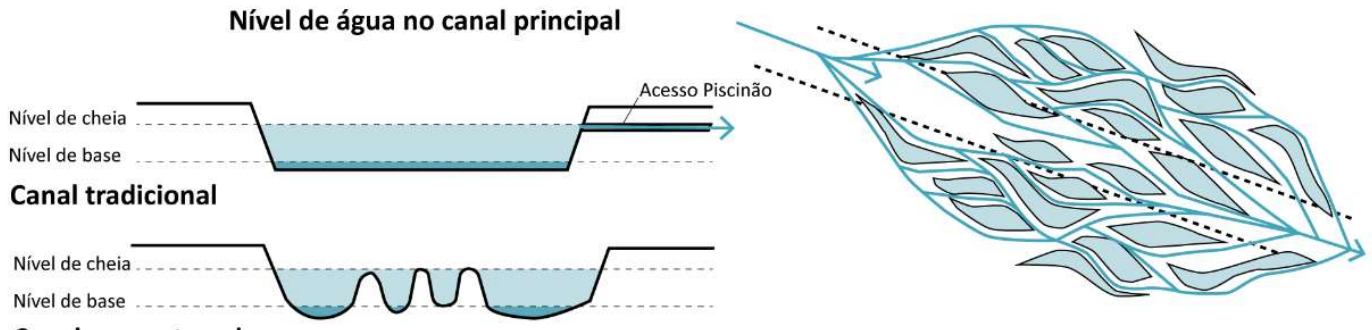

Canal anomatosado

Fonte: elaborado pela autora. 


\subsection{CONSIDERAÇÕES PARA APLICAÇÃO NO MANDAQUI}

O Projeto Jaguaré considerou a necessidade de aplicação de medidas estruturais e não estruturais para o manejo de resíduos sólidos urbanos, focando principalmente na redução dos volumes de cargas difusas e de lixo que chegam até os corpos d'água e sistemas de drenagem, os quais reduzem a capacidade de vazão dessas estruturas e causam danos ambientais, sociais e econômicos. O problema descrito não é específico da Bacia do Jaguaré, mas constante nas demais bacias urbanas da Região Metropolitana de São Paulo, como por exemplo a bacia do Mandaqui e, portanto, poderão se valer das estratégias propostas pelo Projeto. ${ }^{34}$

Quanto à qualidade das águas do escoamento superficial, as conclusões do Projeto Jaguaré indicaram que a instalação de LIDs dispersos na bacia, ocupando cerca de $4,2 \mathrm{~km}^{2}$ ( $25 \%$ da área das vias e $40 \%$ da área ocupada por outros Espaços Abertos), além de aproximadamente $3,6 \mathrm{~km}^{2}$ de área referente aos telhados de edificações ( $25 \%$ dos tetos dos edifícios com tetos verdes ou calha desconectada), pode ser responsável pela remoção de DBO, Nitrogênio Amoniacal e Sólidos Suspensos durante $90 \%$ do tempo e fósforo durante $80 \%$ do tempo (FCTH, 2017). Em relação ao manejo dos volumes de água, é estimado que as tecnologias de controle in-situ possam manejar chuvas de intensidade até TR 2 anos e sua eficácia é considerada ínfima quando relacionada a eventos TR 100 anos. Os grandes volumes de água ficarão a cargo dos reservatórios de detenção e retenção instalados ao longo dos fundos de vale da bacia (ibid).

A fim de compreendermos e lidarmos com as consequências das águas de chuva tanto para as porções mais baixas e planas do relevo quanto para os demais compartimentos topográficos de uma área consolidada como a bacia do Mandaqui, as características de drenagem serão relacionadas aos Compartimentos da Paisagem (Parte II- Capítulo 3). Não é o intuito da tese debruçar-se sobre modelagens e cálculos hidráulicos para avaliar o manejo da quantidade e qualidade das águas, mas sim, compreender as possíveis sinergias, trade-offs e desserviços entre as infraestruturas cinzas e verdes. A área de impacto das enchentes causadas por eventos extremos, calculados para períodos de retorno de até 100 anos será calculada em relação a população diretamente impactada. No fundo de vale, serão verificados a oferta de Espaços

\footnotetext{
${ }^{34}$ Todas as estratégias estruturais e não estruturais focadas no manejo dos resíduos sólidos, propostas pelo Projeto Jaguaré, podem ser acessadas no vol. 2, tomo 3 (FCTH, 2017).
} 
Abertos e o potencial de integração da Infraestrutura Verde. As tecnologias LID apresentadas, tanto para micro quanto para macrodrenagem serão consideradas para o caso do Mandaqui, associadas aos Compartimentos Estruturantes da Paisagem, (ver Parte II- Subcapítulo 3.3) e verificadas quanto à aptidão em fornecer outros Serviços Ecossistêmicos. 


\section{PROJETO RESILIÊNCIA: ESCOLHA DO EIXO EM TRANSECTO DE ESTUDO}

Conforme apresentado durante a introdução da tese, (ver Introdução - Subcapítulo 6.1), o Projeto Resiliência Urbana delimitou um transecto de estudo de $20 \mathrm{~km} \times 5 \mathrm{~km}$, entre os limites da Serra da Cantareira e as várzeas do rio Pinheiros. O caso de estudo abordado no presente trabalho, o fundo de vale do córrego Mandaqui e sua bacia hidrográfica, foi selecionado através da identificação dos Polos, Fragmentos e Corredores (ver Parte I- Subcapítulo 1.2) e analisada a conectividade física através de uma matriz de análise multicriterial.

No limite norte do Transecto estão localizados o Parque Estadual da Cantareira ${ }^{35}$ e o Parque Estadual Alberto Löfgren popularmente conhecido como Horto Florestal ${ }^{36}$, ambos caracterizados como Unidades de Conservação Integral e, portanto, não podem ter seus recursos naturais explorados $^{37}$. Essas áreas configuram-se também como parte das zonas núcleo da Reserva da Biosfera do Cinturão Verde de São Paulo ${ }^{38}$. Se considerarmos suas áreas de amortecimento e transição ${ }^{39}$, parte delas estariam nas áreas ao norte do transecto, onde atualmente a pressão urbana é intensa, mas limitada parcialmente pela presença da Invernada da Polícia Militar, zona de transição do Parque da Cantareira. No âmbito municipal, segundo estudo elaborado pela Secretaria do Verde e do Meio Ambiente (SVMA), esses parques fazem parte das áreas Remanescentes da Mata Atlântica ${ }^{40}$ (SVMA, 2008), que ainda inclui trechos de parques municipais tais como Ibirapuera, Trianon, Luz e Água Branca.

\footnotetext{
35 Lei ordinária no 10228 de 25/09/1968. Fundação para Conservação e a Produção Florestal do Estado de São Paulo.

${ }^{36}$ Lei ordinária no Lei 10228 de 24/09/1968. Instituto Florestal da Secretaria do Meio Ambiente do Estado de São Paulo-SP.

${ }^{37}$ A Unidade de Proteção Integral estabelece regras e normas mais restritivas às áreas com objetivo de preservação da natureza. Não é permitido o consumo direto de recursos naturais produzidos, apenas as atividades recreativas, turísticas e de pesquisa. Mais informações disponíveis em: < https://www.mma.gov.br/areas-protegidas/unidadesde-conservacao/o-que-sao.html >. Acessado em 05/02/2017.

${ }^{38}$ Zonas Núcleo são aquelas onde se encontram os exemplos mais significativos dos remanescentes dos ecossistemas naturais; (PMSP, 2002).

${ }^{39}$ Zonas de Amortecimento são aquelas onde atividades econômicas e o uso da terra devem estar em equilíbrio para garantir a integridade das zonas núcleo; Zonas de Transição, são mais externas e privilegia o uso sustentável do solo, incentivando atividades que aprimorem os meios de produção na direção desse objetivo (PMSP, 2002).

${ }^{40}$ As áreas Remanescentes da Mata Atlântica foram mapeadas pela Secretaria do Verde e Meio Ambiente do município de São Paulo (SVMA) seguindo o Decreto Federal 6.660/2008, que regulamenta a Lei Federal da Mata
} 
Por suas características, os Polos foram identificados no transecto, como o conjunto de formado pelos: Parque Estadual da Cantareira, Horto Florestal e Invernada da Polícia Militar. Já os fragmentos, foram considerados como o conjunto de parques municipais e estaduais urbanos com área inferior aos Polos (Figura 19). Os Corredores são as estruturas aptas a garantir a unidade do sistema, porém no transecto estas estruturas são mínimas ou inexistentes em muitos setores urbanos. Dessa forma, as distintas avenidas que acompanham ou estão sobrepostas aos córregos, localizadas nos fundos de vale, foram identificadas como oportunidades para a instalação de corredores capazes de conectar Fragmentos e Polos e catalisar o verde e o azul no interior do tecido urbano.

Figura 19: Identificação de parques caracterizados como Polos ou Fragmentos dentro da área delimitada pelo transecto de estudo.

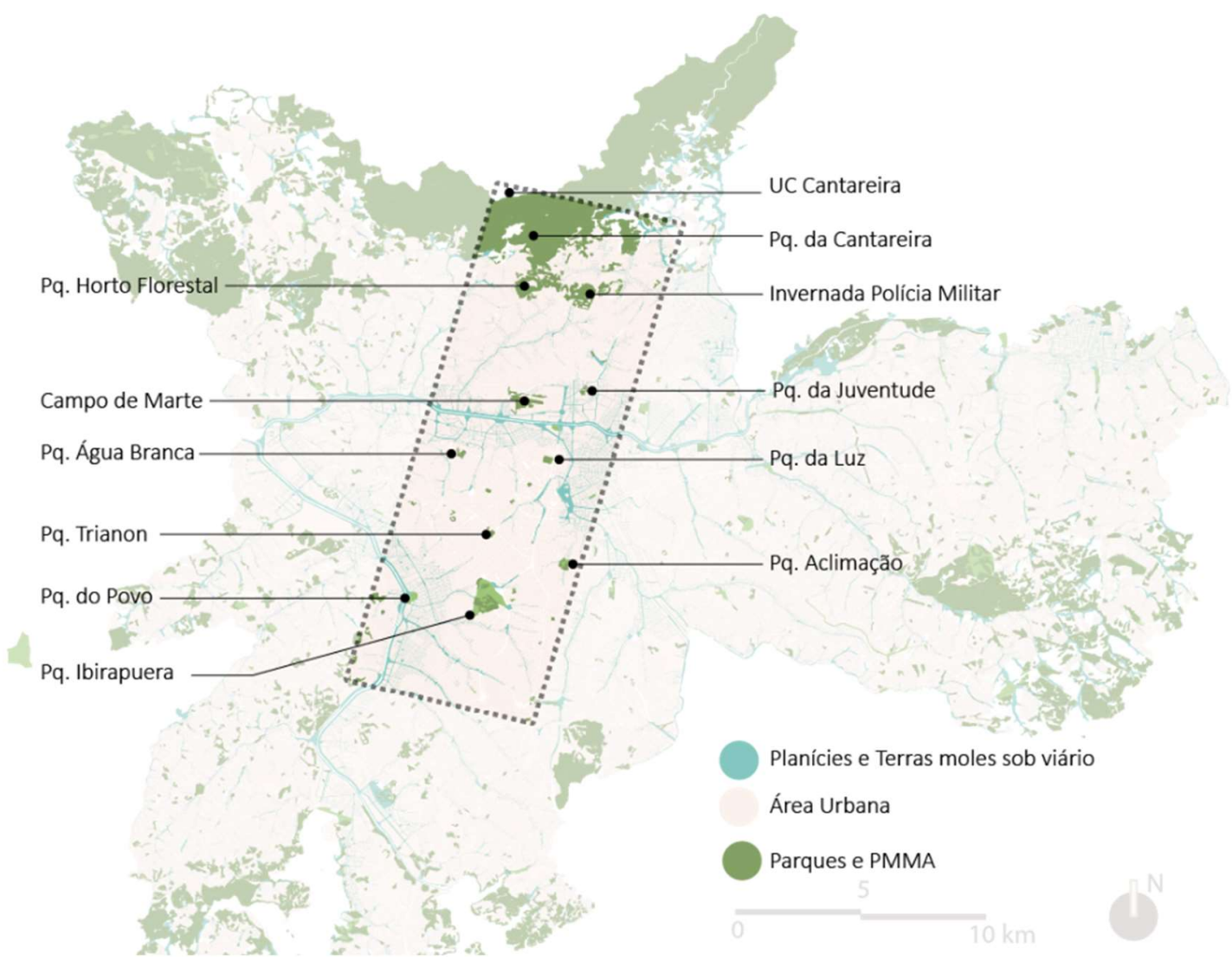

Fonte: MARQUES (2017b, p. 51).

Atlântica. Em São Paulo foram classificadas de acordo com seis categorias distintas. Para maiores informações acessar: http://www.prefeitura.sp.gov.br/cidade/secretarias/meio ambiente/pmma/index.php?p=219941 , Acessado em 02/10/2017. 
No total, 14 avenidas foram selecionadas e relacionadas a critérios que consideravam a situação do córrego: aberto, semiaberto (parcialmente canalizado aberto e subterrâneo) ou subterrâneo, e a presença de outras infraestruturas civis sobrepostas ou subterrâneas às avenidas (pontes, túneis, viadutos e monotrilhos); e a conexão aos Polos e Fragmentos: direta, indireta ou com necessidade de ancoragem (criação de área verde em algum dos extremos da via). A categoria "em estado natural" não foi considerada para a situação do córrego, pois não existiam casos desse tipo relacionados às avenidas. Para cada critério foram definidos pesos variando de -1 a 2, sendo -1 a pior situação e 2 a melhor. Uma vez qualificada a via, os pesos de cada critério foram separadamente associados a escalas variando de "muito ruim" a "muito bom", a classificação "muito bom" não existe para a situação do córrego, pois esta seria atrelada ao estado natural do curso d'água. Finalmente, foi feita uma ponderação unificando os dois critérios para que o potencial final pudesse ser conhecido (Quadro 7).

Quadro 7:Ponderações utilizadas entre os critérios.

\begin{tabular}{|c|c|}
\hline \multicolumn{2}{|c|}{ Associação Situação dos córregos } \\
\hline muito bom & não considerado \\
\hline bom & 2 \\
\hline médio & 1 \\
\hline ruim & 0 \\
\hline muito ruim & $\leq-1$ \\
\hline
\end{tabular}

\begin{tabular}{|c|c|}
\hline \multicolumn{2}{|c|}{ Potencial Final } \\
\hline muito bom & $\geq 4$ \\
\hline bom & 3 ou 4 \\
\hline médio & 1 ou 2 \\
\hline ruim & 0 ou -1 \\
\hline muito ruim & $<-1$ \\
\hline
\end{tabular}

\begin{tabular}{|c|c|}
\hline \multicolumn{2}{|c|}{ Associação Conexão Polos e Fragmentos } \\
\hline muito bom & $\geq 4$ \\
\hline bom & 2 e 3 \\
\hline médio & 1 \\
\hline ruim & 0 \\
\hline muito ruim & $\leq-1$ \\
\hline
\end{tabular}

Fonte: adaptado a partir de MARQUES (2017b).

Como resultado, a avenida Juscelino Kubitcheck teve a pior qualificação, "muito ruim", quanto à situação do córrego (-2), devido a sua condição subterrânea e pela interferência dos dois túneis entre a marginal do rio Pinheiros e o Parque do Ibirapuera (categoria outras infraestruturas). Nesse quesito a avenida Moysés Roysen teve a pontuação mais alta (2), qualificada com "Bom" devido a seu canal completamente aberto. Quanto à conexão a Polos e Fragmentos, os piores resultados encontrados foram das avenidas Pacaembú, Antártica e Jornalista Roberto Marinho 
(-2), e os melhores das avenidas Direitos Humanos, Engenheiro Caetano Álvares (devido à proximidade aos Polos da Cantareira) e Juscelino Kubitcheck (devido a possibilidade de conexão entre o Parque Ibirapuera e o Parque do Povo), todos com 4 pontos. Vale indicar que a análise não considerou a vegetação existente ao longo das vias, apenas a possibilidade física de conexão entre as áreas verdes mais expressivas do transecto.

Finalmente, a avenida Engenheiro Caetano Álvares, localizada ao longo do vale do córrego Mandaqui, foi selecionada como caso de estudo. A ponderação final considerou a qualificação "médio" para a situação do córrego e "muito bom" para a conexão dos Polos e Fragmentos. Essa conclusão deveu-se à proximidade do extremo norte da avenida aos Polos da Cantareira e à condição do córrego, parcialmente canalizado aberto e parcialmente subterrâneo em galerias, sem outras infraestruturas sobrepostas ou subterrâneas. Ainda que a avenida tenha sido classificada com potencial "muito bom", é fisicamente evidente a falta de outras estruturas verdes na direção sul da via, o que implicará na avaliação de distintas possibilidades de Espaços Abertos para a instalação de um corredor verde. A matriz síntese desse processo de análise pode ser acessada na Figura 20.

A metodologia aplicada no estudo teve um caráter exploratório (MARQUES, 2017b), focado na análise de apenas dois critérios relacionados ao potencial conector físico das avenidas de fundo de vale, em relação as áreas verdes e azuis e poderá ser refinada em futuros estudos. No momento em que foi elaborado, indicava-se a necessidade de uma aproximação mais holística a área selecionada, que considerasse aspectos abióticos, bióticos, culturais e temporais. Nos Capítulos 3 e 4 da Parte II, essa aproximação será feita a partir da aplicação dos métodos e indicadores para a análise dos Compartimentos da Paisagem e dos Espaços Abertos que relacionam a escala da bacia hidrográfica do Mandaqui e do eixo, ou fundo de vale. 
Figura 20: Matriz de análise multicriterial; A- Avenidas Selecionadas B- Avenidas com Maior ou Menor Potencial.

\begin{tabular}{|c|c|c|c|c|c|c|c|c|c|c|c|}
\hline & Peso & 0 & 1 & 2 & -1 & 2 & 2 & 2 & 1 & -1 & \\
\hline No. & & & uação Córregc & & Infraestruturas & Cones & ăo Pólo & Conexão & Fragmento & Necessidade & \\
\hline $\begin{array}{c}\text { REF } \\
\text { MAPA }\end{array}$ & Nome Avenida & Subterrâneo & Semi Aberto & Aberto & Sobrepostas & Direta & Indireta & Direta & Indireta & Ancoragem & Potencial \\
\hline 1 & Direiros Humanos & $x$ & & & & 0 & 1 & 1 & 1 & 1 & bom \\
\hline 2 & Eng. Caetano Álvares & & $\mathrm{x}$ & & & 0 & 1 & 1 & 1 & 1 & muito bom \\
\hline 3 & $\begin{array}{l}\text { Pedro Leon Schneider/ } \\
\text { Gen. Ataliba Leonel/ Luiz } \\
\text { Dumont Villares }\end{array}$ & $\mathrm{x}$ & & & & 0 & 0 & 1 & 2 & 1 & médio \\
\hline 4 & Bráz Leme & $x$ & & & & 0 & 0 & 1 & 0 & 1 & ruim \\
\hline 5 & Moysés Roysen & & & $\mathrm{x}$ & & 0 & 0 & 0 & 1 & 1 & médio \\
\hline 6 & $\begin{array}{l}\text { Antartica (Trecho até } \\
\text { Ferrovia) }\end{array}$ & $x$ & & & & 0 & 0 & 0 & 0 & 2 & muito ruim \\
\hline 7 & $\begin{array}{l}\text { Pacaembu (Trecho até } \\
\text { Ferrovia) }\end{array}$ & $\mathrm{x}$ & & & & 0 & 0 & 0 & 0 & 2 & muito ruim \\
\hline 8 & $\begin{array}{l}\text { Nove de Julho (Trecho } \\
\text { NORTE)/Tiradentes }\end{array}$ & $x$ & & & $\begin{array}{c}{ }^{* 1} \text { Túnel av. } \\
\text { Paulista }\end{array}$ & 0 & 0 & 1 & $1^{* 1}$ & 0 & médio \\
\hline 9 & Sumaré & $x$ & & & & 0 & 0 & 0 & 1 & 1 & ruim \\
\hline 10 & $\begin{array}{l}\text { Cidade Jardim/ Nove de } \\
\text { Julho (Trecho SUL) }\end{array}$ & $x$ & & & $\begin{array}{l}{ }^{* 1} \text { Túnel av. } \\
\text { Paulista }\end{array}$ & 0 & 0 & 1 & $1^{*^{1}}$ & 0 & médio \\
\hline 11 & 23 de Maio (Trecho SUL) & $x$ & & & & 0 & 0 & 1 & 0 & 1 & ruim \\
\hline 12 & $\begin{array}{l}\text { Juscelino Kubitchek/ } \\
\text { Antonio Joaquim de } \\
\text { Moura Andrade }\end{array}$ & $x^{*^{2}}$ & & & $*^{2} 02$ túneis & 0 & 0 & 2 & 0 & & bom \\
\hline 13 & dos Bandeirantes & $x$ & & & & 0 & 0 & 0 & 1 & 1 & ruim \\
\hline 14 & $\begin{array}{l}\text { Jornalista Roberto } \\
\text { Marinho }\end{array}$ & & & $x^{*^{3}}$ & $\begin{array}{c}*^{3} \text { Monotrilho } \\
\text { sobre área de } \\
\text { córrego }\end{array}$ & 0 & 0 & 0 & 0 & 2 & ruim \\
\hline
\end{tabular}
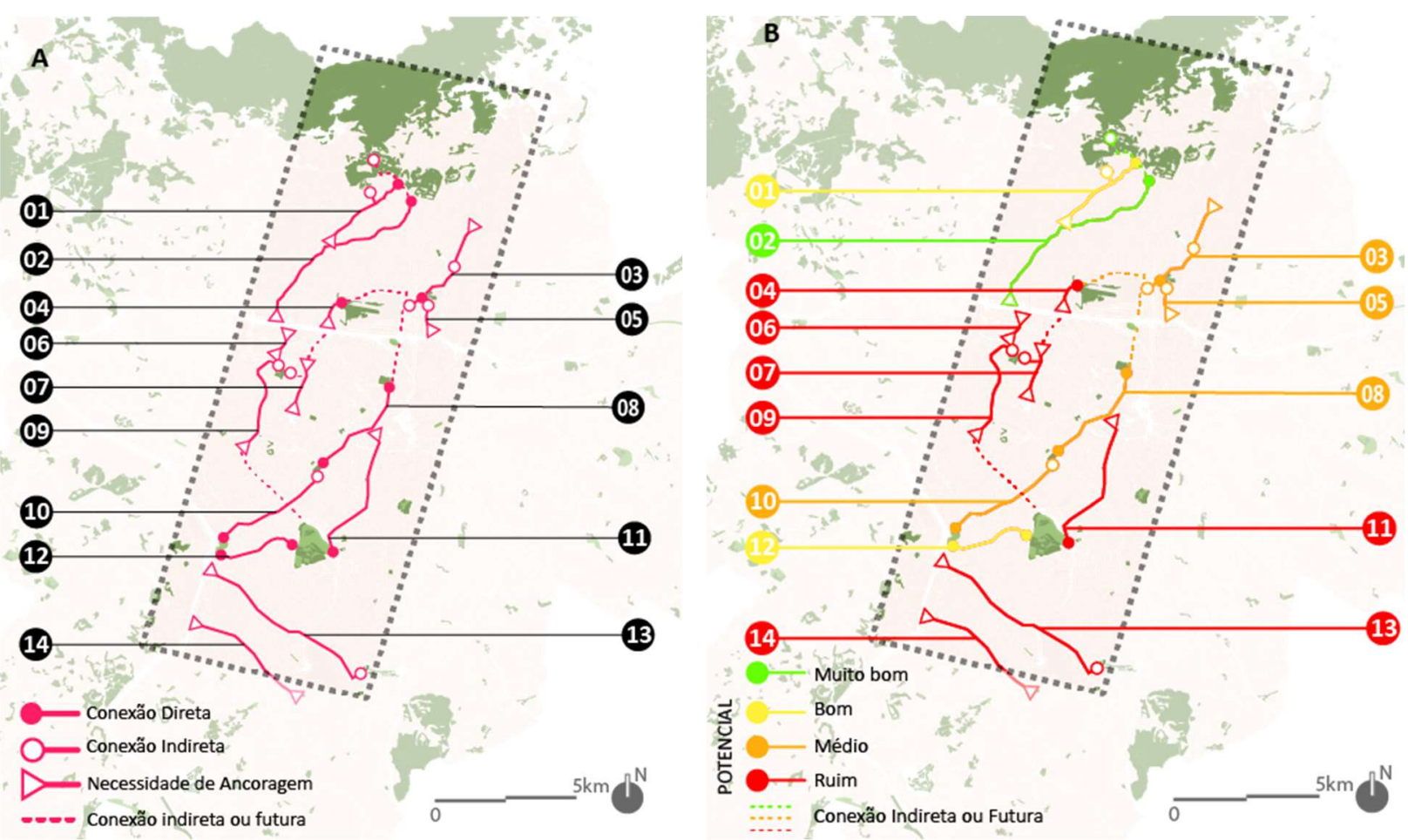

Fonte: MARQUES, (2017b, p. 54). 


\section{CONCEITUAÇÃO DO RECORTE: BACIA E FUNDO DE VALE DO MANDAQUI}

O eixo do Mandaqui conforma o fundo do vale principal da bacia hidrográfica do córrego de mesmo nome. A bacia está localizada integralmente dentro do limite norte da cidade de São Paulo, nas vertentes da serra da Cantareira, à margem direita do rio Tietê. Possui área aproximada de $18,6 \mathrm{~km}^{2}$, ou 2,5\% da área da Bacia hidrográfica do Alto Tietê (Figura 21), e conta com cerca de 63 km de cursos d’água (SMDU, 2016).

Figura 21: Localização da bacia do Mandaqui em relação à Bacia do Alto Tietê.

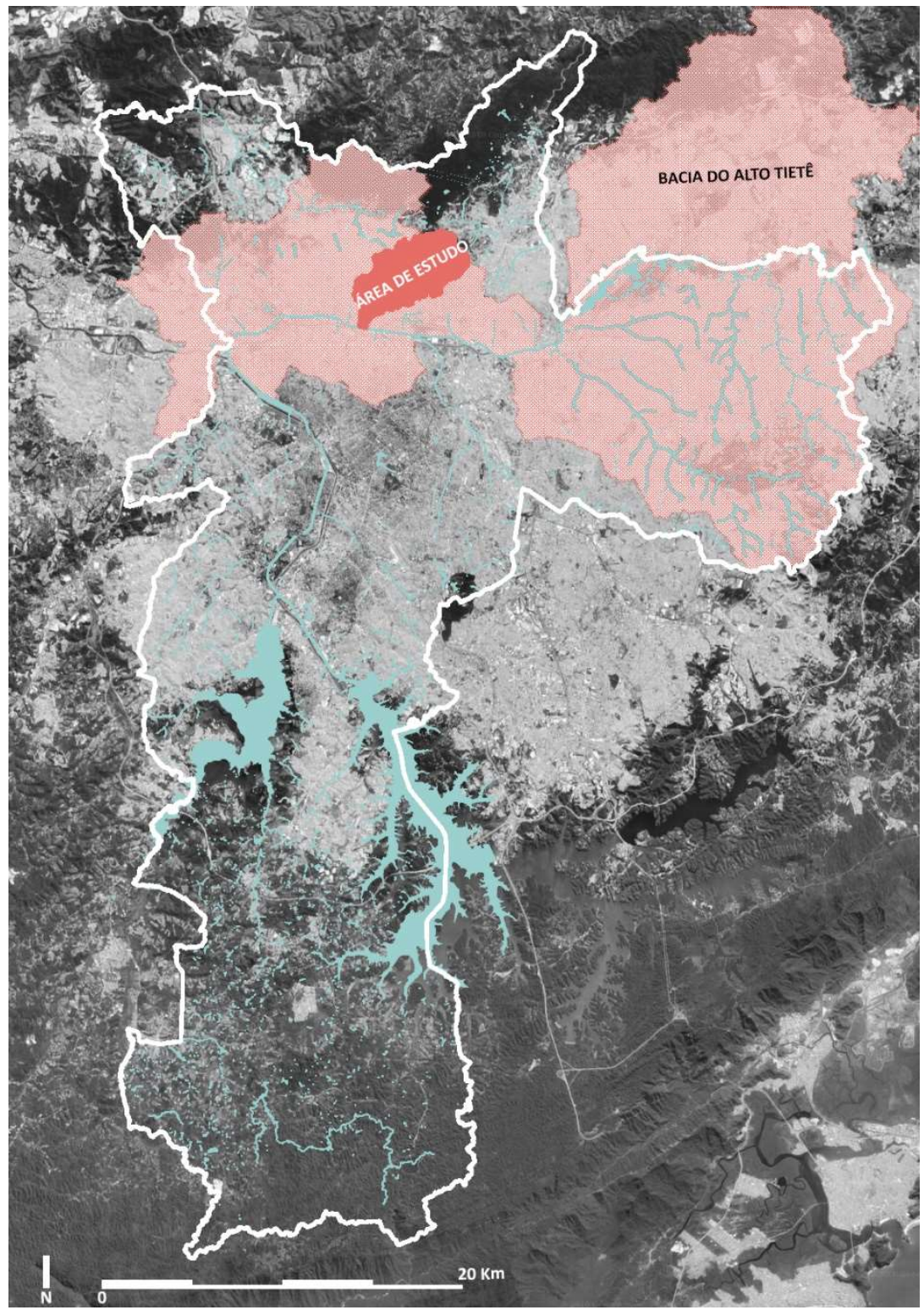

Fonte: elaborado pela autora sobre base de foto satélite obtida por GoogleEarth. 
Dos seus aproximadamente 8,6 km de curso, até a foz, o córrego Mandaqui possui um trecho de nascente de cerca de 775 m em estado natural, no interior da Invernada Militar, seguidos por 4,9 km canalizados sob a avenida Eng ${ }^{\circ}$. Caetano Álvares e os últimos $3 \mathrm{~km}$ abertos canalizados entre as pistas da avenida. Seus principais afluentes são os córregos Lauzane e Tabatinguera. 0 Lauzane se encontra completamente subterrâneo sob a avenida Direitos Humanos, enquanto o Tabatinguera possui um trecho em estado natural, porém com as margens ocupadas por assentamentos irregulares, e um trecho subterrâneo, próximo ao desague no Mandaqui (Figura 22).

Figura 22: Bacia do Mandaqui com hidrografia.

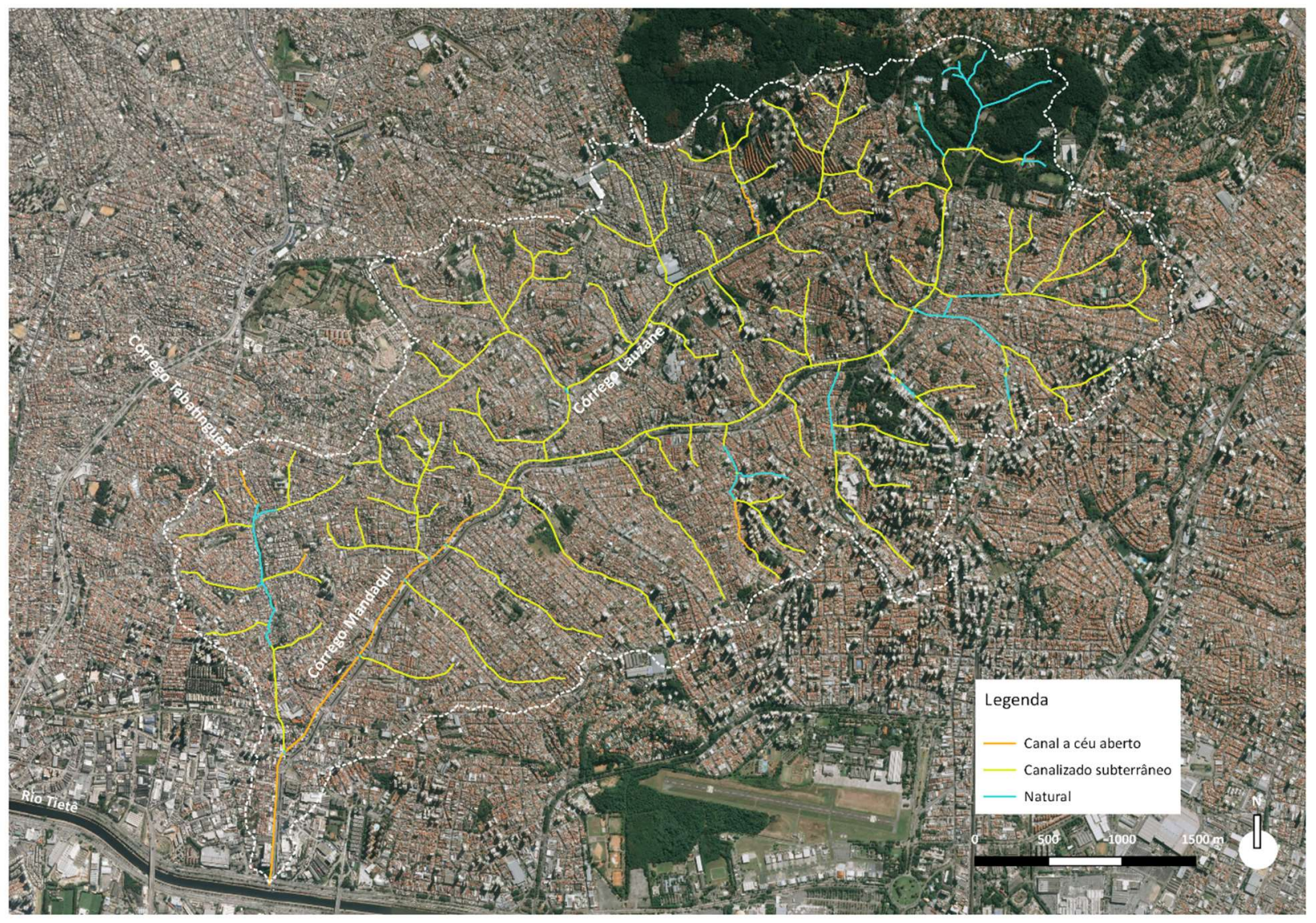

Fonte: elaborado pela autora a partir das bases disponíveis no portal Geosampa.

Cerca de $83 \%$ dos córregos da bacia se encontram em estado subterrâneo. Daqueles abertos em estado natural, notam-se três situações típicas: (1) confinados entre muros de construções ou 
em áreas de favela, não acessíveis; (2) dentro da área da Invernada da Polícia Militar, não acessíveis; ou (3) acessíveis em áreas verdes públicas. A sequência de fotos apresentadas na Figura 23, nos fornece um panorama da situação dos córregos principais ou de seus afluentes.

Figuras 23: Distintas situações dos córregos na bacia do Mandaqui, com ênfase nos eixos dos córregos principais.

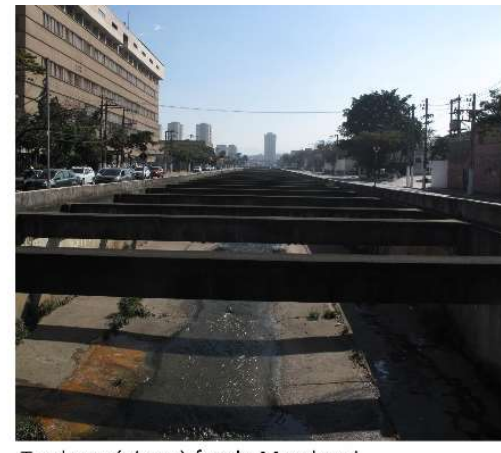

Trecho próximo à foz do Mandaqui

Córrego Lauzane sob av. Direitos Humanos

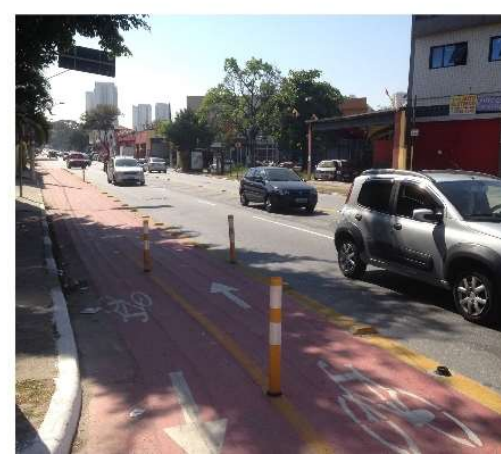

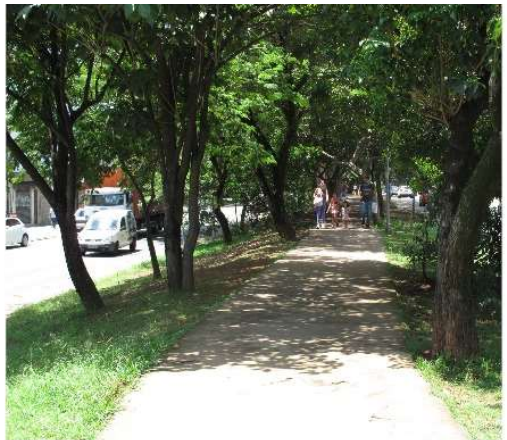

Trecho médio a montante do Mandaqui, sob canteiro central

Córrego Tabatinguera em área de Favela (Fonte: google street view)

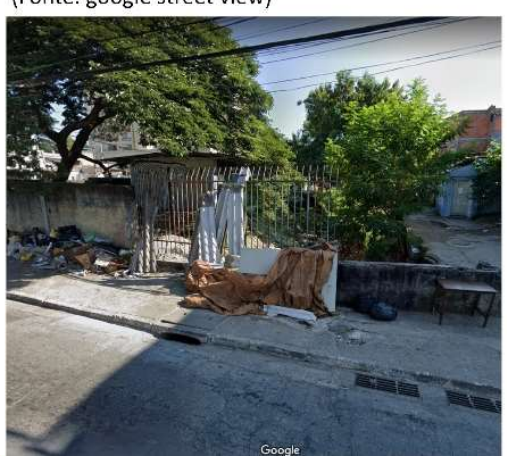

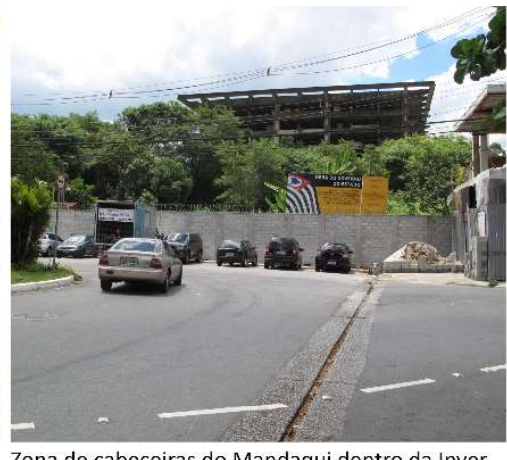

Zona de cabeceiras do Mandaqui dentro da Invernada da Polícia Militar

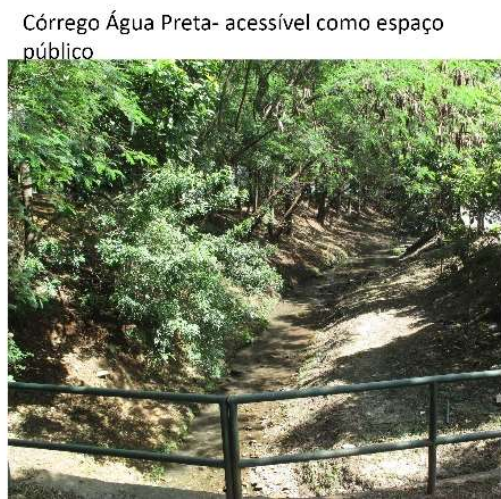

Fonte: fotos tiradas entre 2016 e 2019 pela autora e google street view.

Atualmente a administração municipal da bacia do Mandaqui é compartilhada entre duas Prefeituras Regionais, limitadas territorialmente em função de parâmetros e indicadores socioeconômicos ${ }^{41}$ que podem ser notados espacialmente nas formas de ocupação da paisagem. A subprefeitura Casa Verde- Cachoeirinha (distritos Casa Verde, Limão e Cachoeirinha) é responsável pelo trecho médio inferior da bacia, e de modo geral, conta com maiores índices de vulnerabilidade social (IPVS) e menor Índice de Desenvolvimento Humano Municipal (IDH-M) ${ }^{42}$

\footnotetext{
41 LEI № 13.399, DE 1ㅇ DE AGOSTO DE 2002. Capítulo II- Seção I- Art. 4ㅇ․

${ }^{42}$ Em 2010 o IDH-M da Casa Verde era 0,799 e de Santana- Tucuruvi 0,869. As faixas de desenvolvimento humano incluem as dimensões longevidade, educação e renda, nas categorias: baixo < 0,550; médio, entre 0,550 e 0,699; alto, entre 0,700 e 0,799; muito alto >0,800. (PMSP, 2017).
} 
em relação à subprefeitura Santana- Tucuruví (distritos de Santana, Mandaqui e Tucuruví), responsável pela gestão do trecho médio superior da bacia (Figura 24). Essa diferença é resultado do processo histórico de urbanização e envolve o acesso aos meios de transporte públicos e a conexão às áreas centrais da cidade. Além disso, nota-se a diferença quanto a proximidade às áreas verdes e a presença de arborização urbana, melhores nos setores de Santana- Tucuruvi que naqueles de Casa Verde- Cachoeirinha (Figura 25), fator indicado como uma das principais influências nos preços de imóveis e bem estar das pessoas em áreas urbanas (ver Parte I- Capítulo 4.3). Apesar de índices de IDH alto (Casa Verde- Cachoeirinha) e muito alto (Santana- Tucuruvi), ambas subprefeituras detém diferenças muito grandes entre a população de renda mais alta e mais baixa, mesclando áreas de vulnerabilidade social às áreas com maiores valores de imóveis.

Figura 24 e 25: (esq.) limites das Prefeituras Regionais e Índice Paulista de Vulnerabilidade Social (IPVS). (dir.) Bacia do Mandaqui, Áreas Verdes e Arborização Viária.

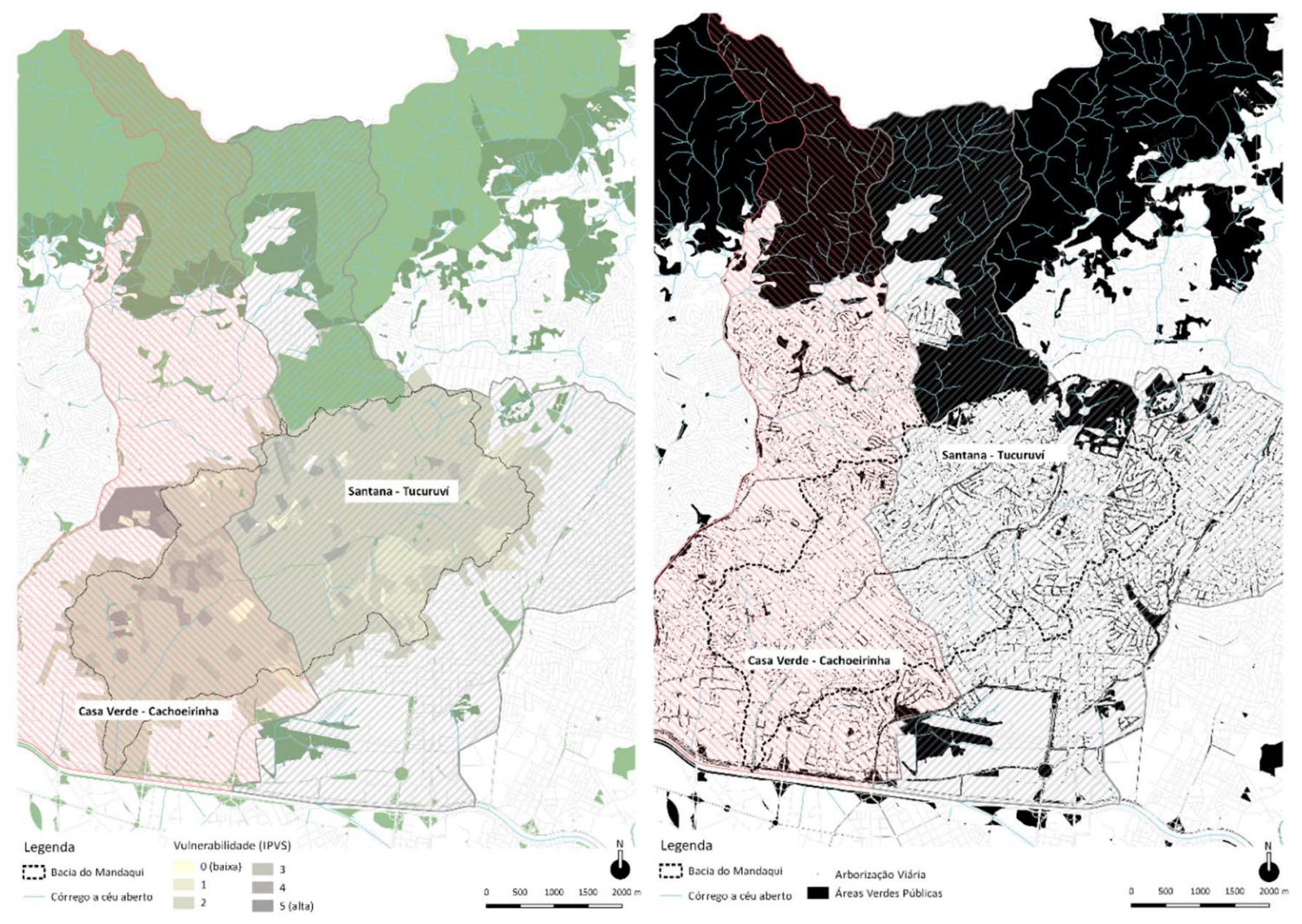

Fonte: elaborado pela autora a partir de dados disponíveis no Geosampa. 
Dentre as atribuições das Prefeituras Regionais estão, a manutenção do sistema viário, da rede de drenagem, da limpeza urbana e da vigilância sanitária e epidemiológica. Também cabe a estes órgãos gestores a formação de instancias intermediárias com subprefeituras vizinhas para o planejamento e gestão de temas que ultrapassem os limites territoriais (PMSP, 2002). É interessante notar esse aporte legislativo, mas na prática ainda existem entraves para que tais associações se consolidem e funcionem de forma efetiva.

A ocupação das áreas da bacia do Mandaqui reflete conflitos e propostas de uso e ocupação de solo característicos da RMSP, e são consequência de diferentes posicionamentos em relação ao ordenamento territorial, a partir de um amplo arcabouço legal das três esferas de governo, assim como da atuação de agentes sociais, políticos e de setores econômicos que tiveram supremacia tanto na alteração física da paisagem (SEABRA, 1987 apud RODRIGUES, 2015, p. $325)^{43}$, quanto na definição de marcos teóricos, soluções técnicas e locais das grandes obras (RODRIGUES, C., 2015).

Embora alguns setores da bacia já fossem ocupados por chácaras no final do século XIX, e contassem com roças datadas do século XVII, foi a construção do Tramway da Cantareira, em 1893, com a finalidade inicial de acessar as áreas mais altas da serra para a construção da Adutora Cantareira e em 1895 passando a fazer o transporte de passageiros, que impulsionou o desenvolvimento de núcleos urbanizados, primeiramente ao redor das estações de trem. A instalação dessa infraestrutura de mobilidade foi chave para tornar as áreas além Tietê acessíveis e estabelecer uma conexão direta entre a São Paulo urbana e a rural que mudaria a dinâmica das paisagens da Cantareira e contribuiria para a justificativa de canalização do Tietê. Em pouco tempo, essas áreas da zona norte passaram a ser reconhecidas não mais como campestres, mas como áreas com possibilidades de recreação e lazer, atraindo pessoas em busca de terrenos baratos ou chácaras próximas a cidade. Essa nova percepção da paisagem resulta, em 1938, na construção do Hospital do Mandaqui, atraído pelas condições de clima ameno e ensolarado, consideradas ideais para o tratamento da tuberculose (Portal do Governo, 2007).

\footnotetext{
43 SEABRA, O. Os meandros dos rios nos meandros do poder: o processo de valorização dos rios e das várzeas do Tietê e Pinheiros na cidade de São Paulo. Tese de Doutorado em Geografia Humana, Faculdade de Filosofia, Letras e Ciências Humanas, Universidade de São Paulo, São Paulo, 1987.
} 
Mas o grande impacto na área foi a canalização do rio Tietê durante a década de 40, associada à mudança do sistema de mobilidade sobre trilhos para um sistema estritamente rodoviarista. As propostas de canalização dos grandes rios já vinham sendo discutidas desde o final do século XIX pelo governo do estado (DAEE, 2018), a partir de um posicionamento político, econômico e projetual essenciais à lógica desenvolvimentista que se instaurou no Brasil e especialmente em São Paulo. A aprovação do Plano de Avenidas, em 1930, passa a orientar a instalação de uma rede de avenidas radiais e perimetrais nas zonas mais planas da cidade, incluindo as rodovias urbanas ao longo dos rios Tietê e Pinheiros, e uma série de parques que dariam suporte à vida urbana (não instalados). Seguido parcialmente somente a partir de meados dos anos 60, essa proposta colaborou para reforçar a prática de canalização e urbanização de fundos de vale (TRAVASSOS,L. 2010) e em pouco tempo se mostrou ineficaz devido ao grande aumento do número de veículos, congestionamento e poluição (MEYER, R. apud ANELLI, 2007, s/ pagina) ${ }^{44}$.

A lógica das várzeas já estava completamente alterada. Distintos programas foram criados para reforçar o processo de saneamento e instalação de avenidas de fundos de vale ${ }^{45}$. Os bairros da bacia do Mandaqui e da zona norte em geral, reconhecidos até então pelas várzeas abertas e águas que pareciam fluir na mesma velocidade que o pacato estilo de vida das pessoas e o lento desenvolvimento urbano, foram bruscamente alteradas. A zona norte deveria acompanhar o progresso urbano de São Paulo. A desativação do Tramway da Cantareira, em 1964, seguida pela canalização do córrego Mandaqui forçou um desenvolvimento urbano acelerado que ficou à mercê da instalação do sistema viário como única forma de transporte, até hoje deficitário.

O Mandaqui estava incluído no Programa Municipal de Drenagem, de 1974, juntamente a outros 28 córregos, mas só começou a ser saneado em 1979 (TRAVASSOS, 2004). O processo de canalização e instalação da avenida Engenheiro Caetano Álvares durou aproximadamente dois anos, mas a adequação das obras perdurou até o final dos anos 90, acompanhado do saneamento do córrego Lauzane e da construção da avenida Direitos Humanos (de acordo com os Decretos municipais publicados entre 1992 e 1997). As Figuras 26 e 27 apresentam respectivamente, o

\footnotetext{
${ }^{44}$ MEYER, Regina. Metrópole e urbanismo: São Paulo anos 50. Tese de doutorado. São Paulo, FAU USP, 1991

${ }^{45}$ Programa Avenidas em Fundo de Vale (1975); Programa de Canalização e Implantação de Vias de Fundo de Vale (1987); Geprocav (1994).
} 
mapa da bacia e seu contexto urbano na década de 1930 (SARA, 1930) e o plano de canalização do Mandaqui, proposto inicialmente na década de 60, quando a bacia contava com aproximadamente $20 \%$ de sua área impermeabilizada (acervo SIURB).

Figura 26: Bacia do Mandaqui em 1930, com hidrografia e linhas de Tramway.

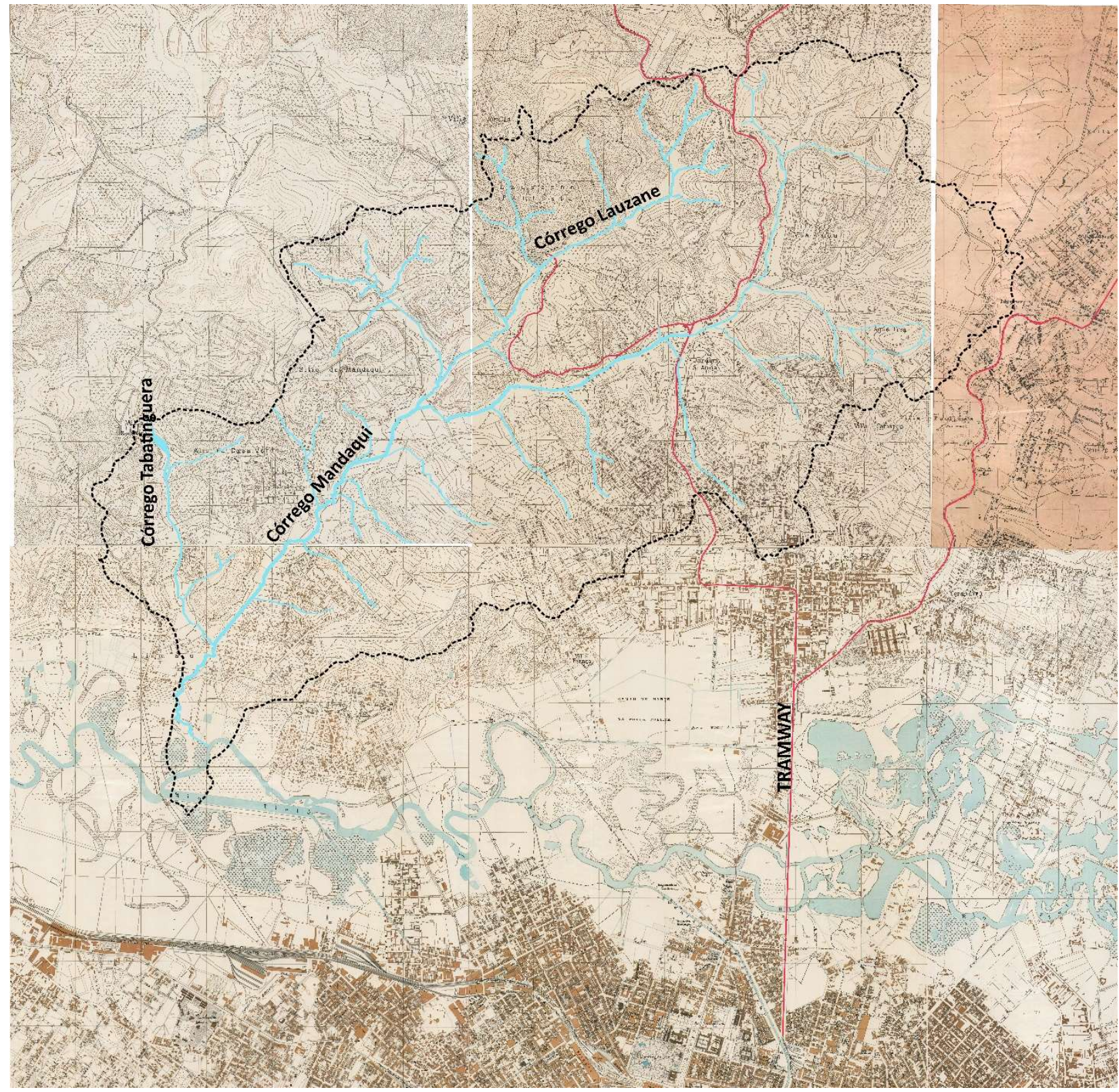

Fonte: elaborado pela autora a partir de SARA (1930). 
Figura 27: Proposta de canalização do córrego Mandaqui na década de 1960.

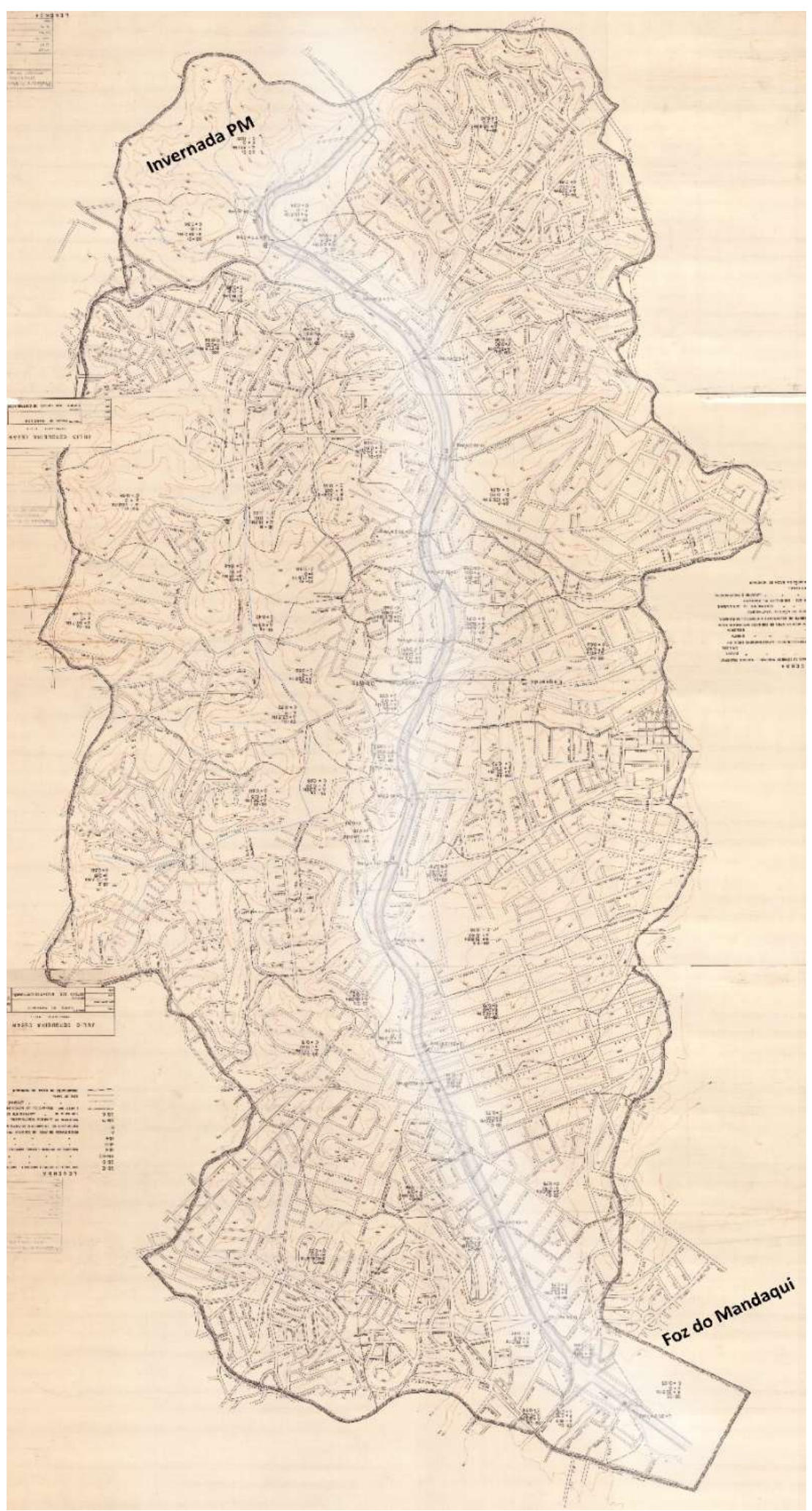

Fonte: elaborado pela autora a partir de cartografia disponível no acervo da SIURB. 
As alterações no fundo de vale do Mandaqui foram marcadas pela canalização do córrego, mas de certa forma ficaram estagnadas com o predomínio de edifícios de no máximo quatro pavimentos, resultando em uma insolação maior de todo o eixo. Os cortes da Figura 28 comparam a situação do fundo de vale entre os anos 1930 e 2019.

Figura 28: Corte transversal ao fundo de vale, nas imediações da avenida Dr. Meireles Reis, apontando a situação da ocupação da várzea em 1930 e 2019.

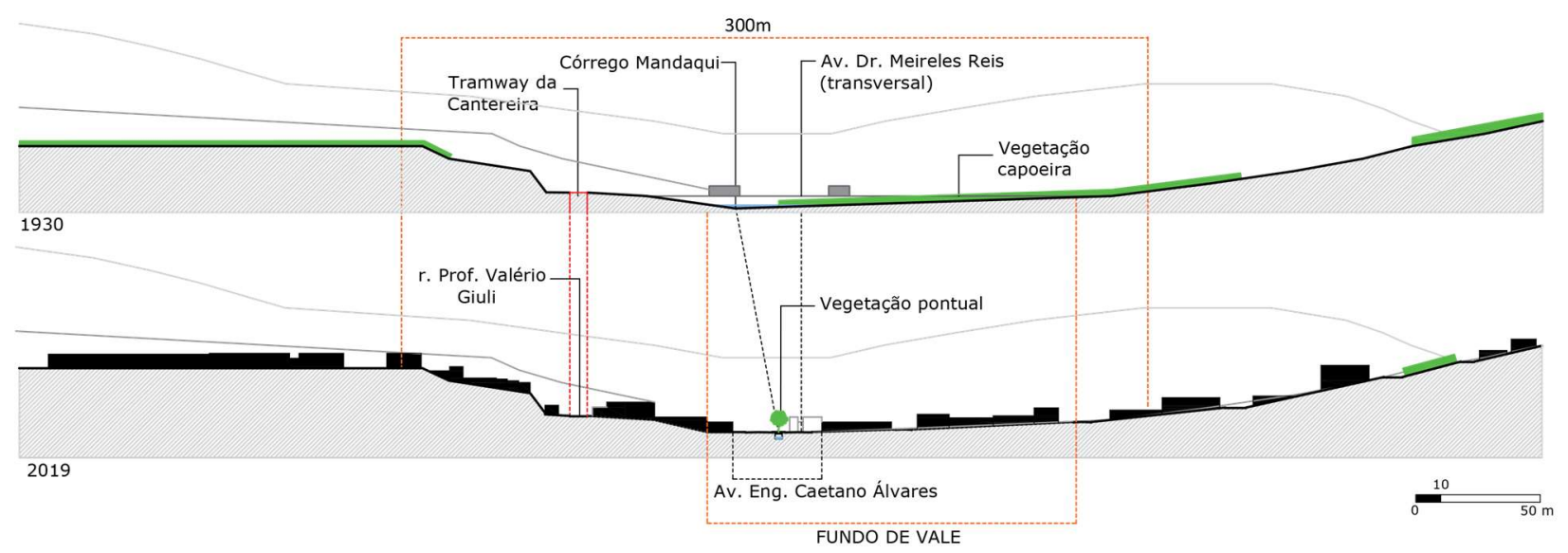

Fonte: elaborado pela autora.

Apoiado por políticas públicas que incentivam o uso de bicicletas a partir da instalação de ciclovias e ciclofaixas (PDE, 2014) e pela construção de passeios públicos para os pedestres (PDE, 2001), o canteiro central da avenida passou a acolher uma dinâmica urbana previamente comprometida pelo saneamento do vale e instalação dos leitos carroçáveis. O fenômeno de ocupação das áreas verdes centrais da avenida também é resultado da carência por outros espaços públicos verdes próximos às moradias e da facilidade em mover-se a pé ou em bicicleta por essas áreas, devido à baixa declividade. Os cortes AA', BB' e CC' (Figura 29) mostram situações típicas da avenida de fundo de vale em três pontos do eixo, onde é possível visualizar a relação entre as infraestruturas de mobilidade, drenagem e o canteiro central.

A contextura atual da trama urbana formada pelas vias públicas do Mandaqui, demonstra claramente a falta de planejamento de uma rede estrutural de mobilidade, suprimida pela necessidade latente de saneamento das várzeas e instalação de avenidas, como descrito anteriormente, quase sempre justificadas pela insalubridade associada às planícies, aos riscos 
gerados pelas dinâmicas das paisagens fluviais ou pela emergência de um setor econômico (RODRIGUES, 2015).

Figura 29: Cortes típicos da avenida de fundo de vale do Mandaqui.
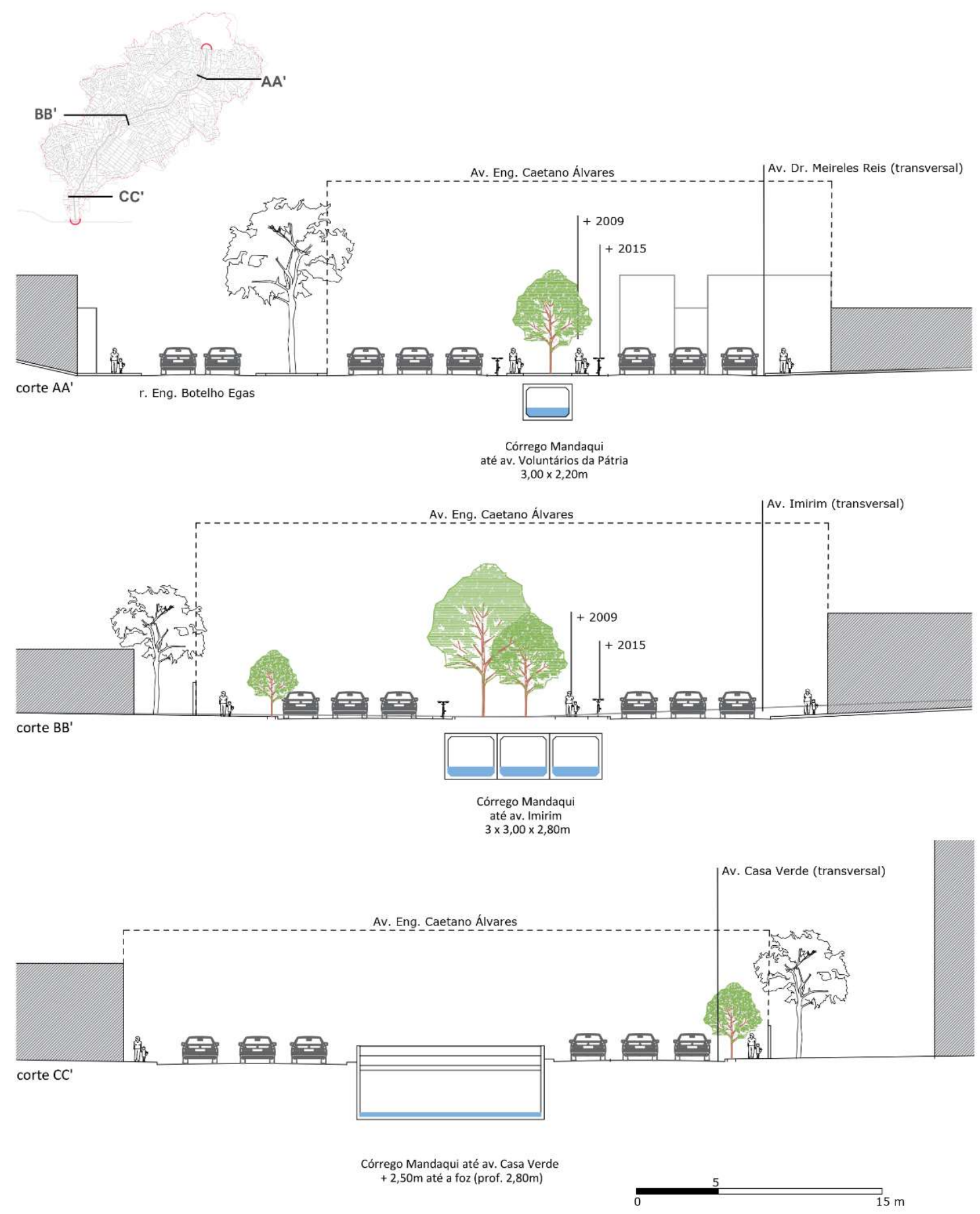

Fonte: elaborado pela autora. 
Na bacia, é evidente a debilidade tanto das conexões oeste- leste quanto entre as margens norte e sul do rio Tietê. No primeiro caso, nota-se a presença de vias transversais ao vale do Mandaqui, nomeando as principais: av. Casa Verde; rua Zilda; av. Imirim; av. Conselheiro Moreira de Barros e av. Voluntário da Pátria. Muitas delas evocam os traçados e larguras estreitas, originais das estradas que desafiavam o relevo acentuado da serra da Cantareira no início do século passado. O transporte público é feito somente por ônibus, e embora tenham pontos espalhados por toda bacia, normalmente tardam em trafegar por vias que não suportam o fluxo veicular. Quanto à conexão norte- sul entre as marginais do Tietê, a própria avenida Engenheiro Caetano Álvares destoa como via estrutural, pois "liga nada a lugar nenhum", parecendo ser apenas a resposta padrão que entoou o saneamento dos fundos de vale durante o século XX. Instalada a partir das pistas da marginal direita do rio, não possui uma ponte para cruzá-lo, tendo que direcionar todo o fluxo de transporte para as pontes do Limão, Casa Verde ou Júlio de Mesquita Neto. No seu outro extremo, a avenida termina em um óvalo em frente à área de conservação da Invernada da Polícia Militar, inacessível, e o trânsito de veículos e pessoas passa a ser desviado para vias transversais estreitas (Figura 30). Estas características fazem com que tanto o trecho da avenida localizado abaixo da avenida Casa Verde quanto acima da avenida Voluntários da Pátria, pareçam superdimensionados, devido ao baixo fluxo veicular e de pessoas, desviadas para vias perpendiculares nos outros trechos da avenida. Parte importante do acesso à bacia é feita pela avenida Voluntário da Pátria que conecta à avenida Cruzeiro do Sul, onde a rota do Tramway da Cantareira foi retomada parcialmente, pela linha 1 do metro (Santana/Tucuruvi- Jabaquara). A presença do Terminal Santana e do Terminal Rodoviário Tietê, fazem dessa área um dos grandes polos de mobilidade da cidade e a principal entrada da zona norte.

Na avenida Caetano Álvares, entre as ruas Domingos Torres e Zilda, funciona uma faixa exclusiva de ônibus à direita, classe IV, ou seja, com funcionamento em horários específicos do dia e da noite (PlanMob/SP, 2016). O PDE (2016) considera uma área de influência a partir do eixo da via, por ser um corredor, de 150 m, distância que, em buffer, compreende quase a largura total 
do fundo de vale do Mandaqui. Esse buffer será demarcado nos mapas de análise, como referência.

Figura 30: Sistema viário da bacia do Mandaqui e arredores.

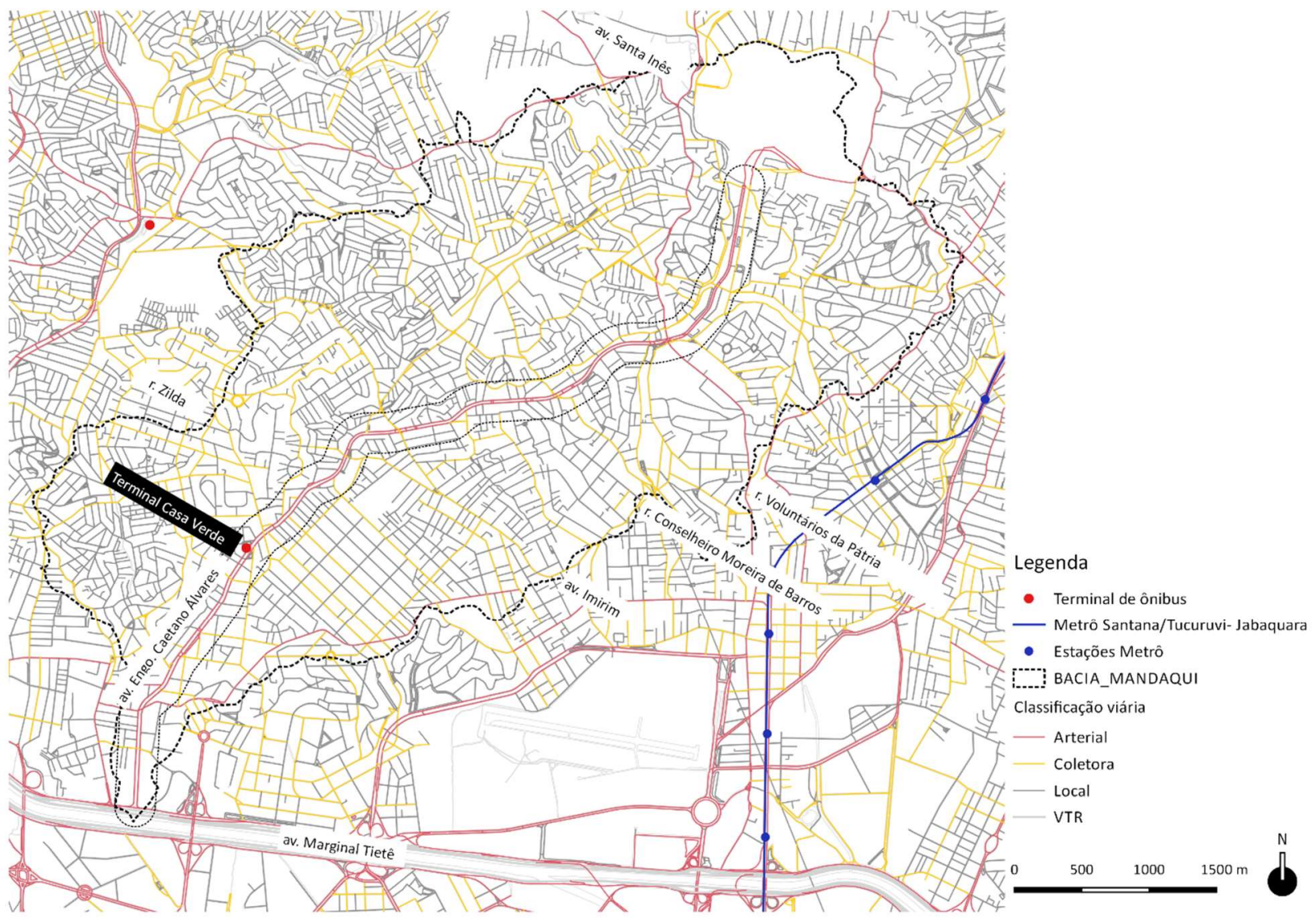

Fonte: elaborado pela autora a partir de dados disponíveis no Geosampa.

Dados do censo 2010 indicam cerca de 315.500 habitantes na bacia do Mandaqui, (IBGE, 2010). Para uma projeção a 2020 a média de crescimento populacional foi calculada a partir dos índices para os distritos do Mandaqui, Casa Verde, Limão e Santana sendo estes os de maior influência na bacia. Nota-se uma tendência de decrescimento populacional na década de 20002010, que inferem porcentagens muito baixas, -0,05\%, em comparação as médias do município para o mesmo período, 7,85\% (Quadro 8). Consideramos a tendência a estabilização do crescimento, indicada para a cidade de São Paulo, replicando assim a porcentagem da última década para projeção a 2020, o que resulta em aproximadamente 315.342 habitantes. O aumento ou redução da população na área depende de distintos fatores dentre eles, acesso a 
infraestruturas de mobilidade, educação e cultura, oferta de empregos e melhora da qualidade ambiental dos bairros.

Quadro 8: Média de crescimento populacional nas últimas décadas nos principais distritos de influência na bacia do Mandaqui comparados com São Paulo.

\begin{tabular}{|l|r|r|r|}
\hline & $1980-1990$ & $1990-2000$ & \multicolumn{1}{|c|}{$2000-2010$} \\
\hline Mandaqui & $17.93 \%$ & $-0.87 \%$ & $4.33 \%$ \\
\hline Santana & $-0.97 \%$ & $-9.46 \%$ & $-4.70 \%$ \\
\hline Casa Verde & $-6.82 \%$ & $-13.24 \%$ & $2.39 \%$ \\
\hline Limão & $1.70 \%$ & $-9.26 \%$ & $-2.21 \%$ \\
\hline Média & $\mathbf{2 . 9 6 \%}$ & $-\mathbf{8 . 2 1 \%}$ & $-\mathbf{0 . 0 5 \%}$ \\
\hline Município de São Paulo & $13.58 \%$ & $8.17 \%$ & $7.85 \%$ \\
\hline
\end{tabular}

Fonte: elaborado pela autora a partir de dados fornecidos pela Secretaria de Desenvolvimento Urbano da Prefeitura de São Paulo. ${ }^{46}$

Aproximadamente $2 / 3$ dos habitantes estão assentados em residências unifamiliares de até 03 pavimentos, configurando uma baixa densidade populacional (média de 312 hab/ ha) e o uso do solo predominantemente residencial, seguindo a tendência de toda a zona norte de São Paulo $^{47}$. A baixa densidade não garante que existam áreas verdes ou espaços abertos em abundância devido às pequenas dimensões dos lotes, muitos deles variando até $125 \mathrm{~m}^{2}$, e as altas taxas de impermeabilização, que podem chegar a $85 \%$ nos lotes menores e $100 \%$ em lotes industriais ou de grandes comércios. Em meio a um mar de telhados de telhas de barro, é possível identificar núcleos de edifícios com mais de 10 pisos, principalmente ao longo e nas proximidades da rua Voluntários da Pátria, além de torres ou pequenos núcleos pontuais espraiados pela bacia. Também se diferenciam áreas com uso predominantemente comercial ou industrial leve ao longo da avenida Engenheiro Caetano Álvares e próximo à Marginal Tietê, e grandes equipamentos como o Hospital do Mandaqui e a Invernada da Polícia Militar pelas suas dimensões e cobertura vegetal densa. Existem ainda algumas favelas esparsas na bacia, as maiores ao longo e nas imediações do córrego Tabatinguera e margeando a Invernada da Polícia Militar (Figuras 31 e 32).

\footnotetext{
${ }^{46}$ SMDU. Disponível em: <https://www.prefeitura.sp.gov.br/cidade/secretarias/urbanismo/dados estatisticos/info cidade/demografia/inde x.php?p=260265> Acesso em: 10/01/2018

${ }^{47}$ A região Norte de São Paulo possui 19,8\% dos moradores e 10,8\% dos empregos da cidade (PlanMob/SP, 2015, p. 62).
} 
Figura 31: Mapa de uso do solo atual.

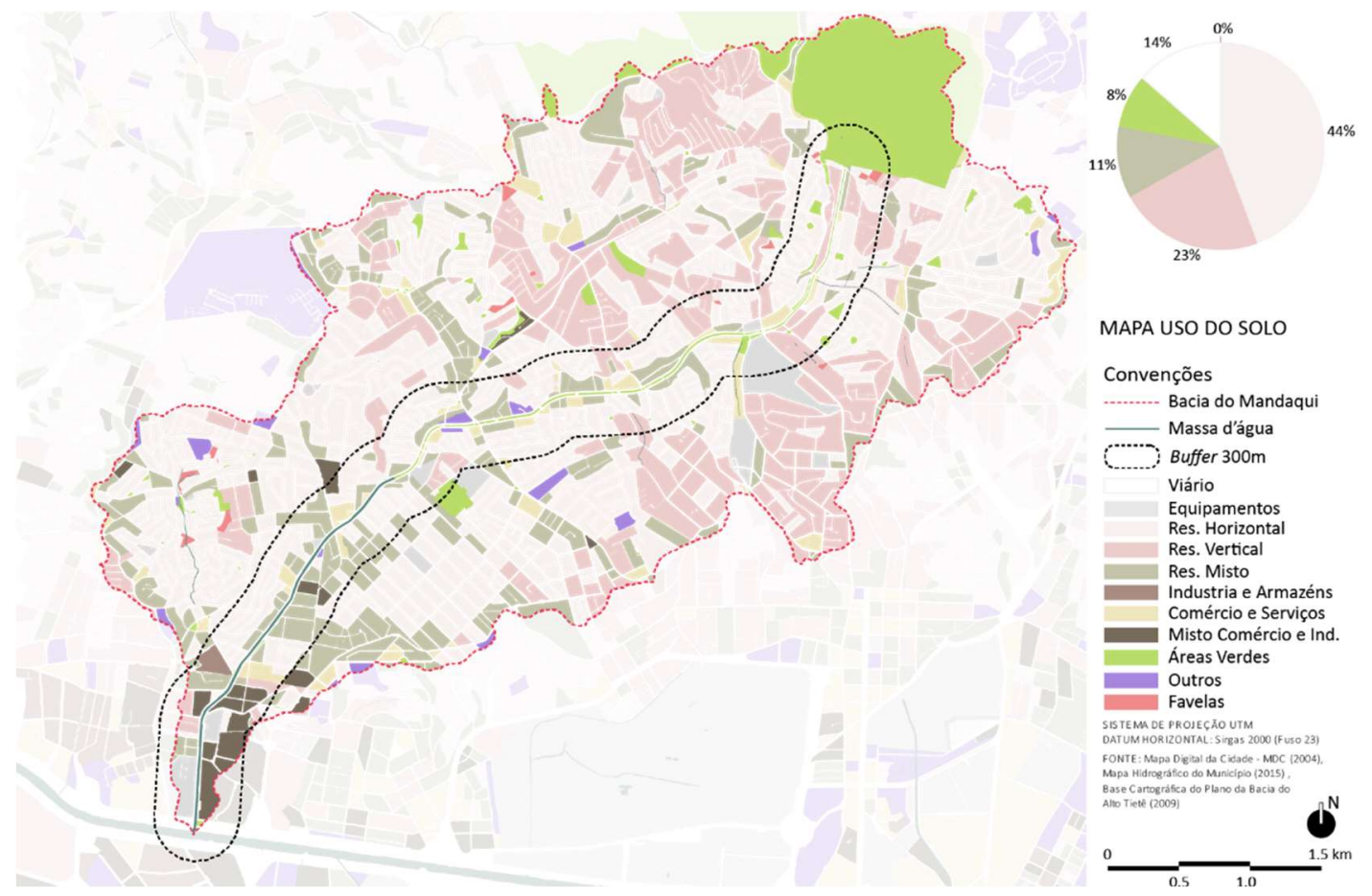

Fonte: elaborado pela autora, a partir do MDC (2010).

Figura 32:Imagens do uso do solo da Bacia.

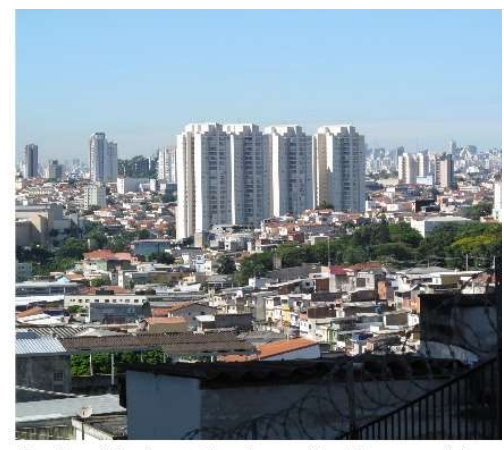

Predomínio de residencias unifamiliares e núcleos de edifícios acima de 10 pavimentos

Lojas dedicadas ao comércio e serviços para automóveis

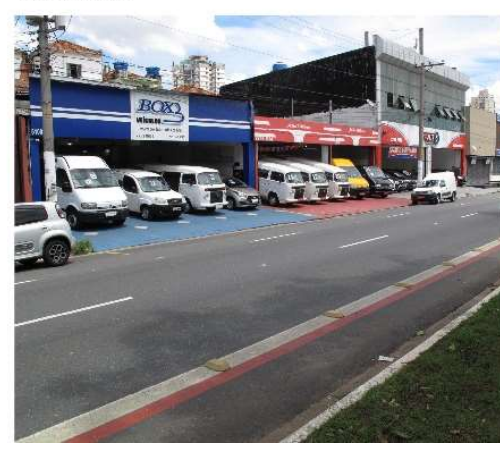

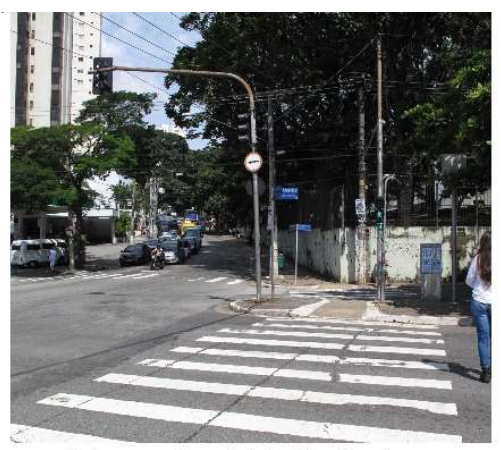

Entorno ao hospital do Mandaqui

Áreas predominantemente residenciais com núcleos de favela

Grandes equipamentos próximos à foz

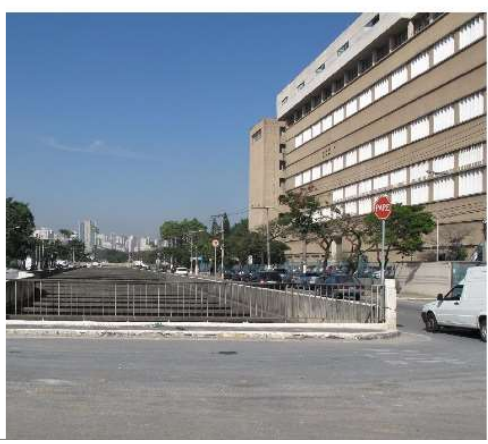

Área com restaurantes ao longo do fundo de vale

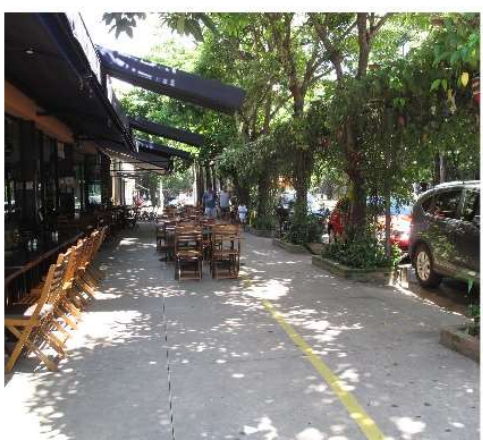

Fonte: fotos tiradas pela autora entre 2016 e 2019. 
O uso de solo ao longo da avenida Engenheiro Caetano Álvares é marcado pela presença de lojas dedicadas à comercialização de peças, acessórios e automóveis, além de oficinas mecânicas. Instaladas de forma concentrada ou dispersa, essa característica reflete a intensidade do transito veicular privado na bacia e influencia bastante a caminhabilidade ao longo da via, devido principalmente a dois motivos, primeiro, as calçadas enfrente a estas lojas são inclinadas em direção ao leito carroçável para facilitar o ingresso de automóveis e normalmente não possuem nenhuma vegetação; segundo, o tipo de comércio existente aí, atende somente à população que se locomove em carros privados, portanto de maior renda, caracterizada pela busca desses serviços específicos de forma esporádica (por exemplo, quando necessitam comprar ou vender um automóvel ou consertar algo em seu carro), tornando-se não atrativa para uma grande parte da população em suas atividades de rotina. Em meio a este uso do solo predominante é possível encontrar pontualmente lojas, restaurantes, bancos e residências de até 04 pavimentos. A existência de alguns equipamentos de grande porte como os hipermercados Assaí e Extra e o Hospital do Mandaqui podem ser identificados como polos geradores de tráfico na bacia.

Os bairros da bacia do Mandaqui abrigam galpões das sedes de distintas escolas de samba, tanto do grupo especial quanto das demais divisões. Há uma certa concentração das áreas do distrito da Casa Verde e outra próxima à Invernada da Polícia Militar.

Nota-se também a existência de vários imóveis abandonados ou a venda com pontos de concentração no entroncamento da Caetano Álvares e Imirim tanto a jusante quanto a montante da bacia. A avenida Imirim também possui uma sequência de imóveis vazios. Nas áreas da Casa Verde e Limão também existe uma forte presença de imóveis, sobretudo casas, a venda, além de construções abandonadas. Esse fenômeno pode ter distintas razões, estando associado ao declínio no número de habitantes nos últimos anos, conforme mencionado anteriormente.

\subsection{PLANOS, AÇÕES E LEGISLAÇÃO COM IMPACTO NA BACIA DO MANDAQUI}

Este subcapítulo tem o objetivo de fornecer um panorama quanto aos planos, programas e legislação existentes e que impactam diretamente o uso e ocupação do solo na bacia do Mandaqui. O conjunto de instrumentos legais existente no país, dedicados aos recursos hídricos, 
à proteção ambiental e ao planejamento urbano, são provenientes das distintas esferas de governo e muitas vezes guardam contradições que tornam a aplicação desses instrumentos um desafio em qualquer escala do território.

É interessante notar que o Código de Águas Brasileiro, de 1934, tenha feito referência ao "regímen das águas", propondo que se devesse considerar os limites das planícies de inundação e dos baixos terraços além do grau de ocupação da bacia hidrográfica e seu impacto na dinâmica hidrológica (RODRIGUES, 2015). Infelizmente essa postura nunca foi aplicada ao ordenamento territorial brasileiro, sendo respeitada somente as demarcações métricas a partir do canal fluvial definidas pelo Código Florestal (ibid). Com primeira versão também em 1934, o Código Florestal propunha uma faixa de proteção as matas ciliares de $5 \mathrm{~m}$ ao longo de cursos d'água de até $10 \mathrm{~m}$ de largura. Essa é a largura encontrada ao longo da maioria dos córregos em estado natural na bacia do Mandaqui, com exceção daqueles localizados no interior da área de conservação da Invernada da Polícia Militar, muito mais amplos.

Ao longo dos anos o Código Florestal vem passando por inúmeras revisões, mas mantém brechas e a falta de limites para sua aplicação, urbana ou não urbana, que seguem motivando diversos conflitos e discussões a respeito de sua viabilidade. Em 1965 o Código incorpora a nomenclatura "Áreas de Preservação Permanente-APP", para as faixas de vegetação a serem mantidas ao longo dos córregos, enfatizando a preservação das funções ambientais desempenhadas por estas áreas, mas sem considerar as delimitações espaciais dos sistemas que protegiam solos, nascentes, rios, vegetação e bacias hidrográficas em sua dinâmica original (RODRIGUES, 2015). Outra questão, se refere a que somente vinte anos depois da indicação das APPs, a largura dessas áreas foi alterada para $30 \mathrm{~m}$, ainda em relação aos cursos d'água de até $10 \mathrm{~m}$ de largura, o que possibilitou a demarcação de inúmeros loteamentos em distâncias menores que esta. Além disso, buscando respaldo no Artigo 30 da Constituição de 1988, que estabelece a autonomia do município para legislar sobre assuntos de interesse local, tais como o uso de solo, muitos municípios seguiram aprovando empreendimentos urbanos com distâncias inferiores aos $30 \mathrm{~m}$ estabelecidos. Esse é um entrave jurídico bastante discutido e que gera grande diferença de opinião quanto a sua autenticidade, uma vez que diversos juristas e autores afirmam que uma legislação municipal não pode ter força legal perante uma lei federal. 
Outro fator que merece atenção, está relacionado ao fato de que o Código Florestal vem expressando, desde de sua primeira publicação, a preocupação em manter as funções ambientais exercidas pelas faixas de vegetação ciliar ao longo dos cursos d'água, enquanto as leis que regem o parcelamento do solo urbano, preocupam-se em estabelecer uma distância mínima das edificações aos cursos d'água, as áreas non edificandi, com o objetivo de garantir a segurança humana, a saúde coletiva e a harmonia arquitetônica das ocupações urbanas (FCTH, 2017). Essa diferença de objetivo é bastante importante nos contextos urbanos, pois no caso das leis de parcelamento, não garantem a permanência de áreas verdes ao longo dos cursos d'água, abrindo assim a possibilidade para que essas porções sejam ocupadas por vias marginais, o que historicamente deu respaldo ao formato tradicional de saneamento dos fundos de vale de São Paulo e da bacia do Mandaqui.

A falta de limites do Código Florestal também dificulta sua aplicação, pois trata os cursos d'água em ambientes urbanos e não urbanos do mesmo modo, sem considerar os conflitos, usos e especificidades inerentes a cada uma das tipologias de ocupação do solo, ecossistemas e biomas. Nesse sentido, o CONAMA, vem tendo papel ativo em propor a flexibilização das APPs urbanas, por exemplo ao regulamentar que, em casos excepcionais de utilidade pública ou de interesse social, possa haver a ocupação, supressão ou intervenção em Áreas de Proteção Permanente (CONAMA resolução 369/2006), facilitando, mediante comprovação por parte do proponente do projeto quanto a inexistência de outras alternativas, a instalação de parques lineares e urbanização de favelas nessas áreas (TRAVASSOS, 2010). Seguindo essa tendência o Código Florestal, revisado em 2012, afrouxa ainda mais as diretrizes relacionadas as APPs, mas passa a não exigir evidências técnicas ou comprovações do proponente do projeto, autorizando o uso dessas áreas para a instalação de sistema viário e uso para realização de eventos esportivos. Há, portanto, uma alteração da visão inicialmente bastante conservadora quanto a preservação das matas ciliares para uma proposta bastante fluida e que passa a incorrer riscos eminentes de danos as áreas protegidas.

Na bacia do Mandaqui, um dos maiores impasses atuais quanto a ocupação das APPs está vinculado as margens do córrego Tabatinguera, ocupadas por favelas, e alvo de atenção no Plano Diretor Estratégico do município (PDE- Lei no 16.050/2014) como Zona de Interesse Social- ZEIS 
do tipo 1, ainda sem projeto definido. Nas zonas limítrofes entre as áreas de conservação da Cantareira e o urbano, vários conflitos vêm sendo travados quanto à ocupação desses setores por população em busca de áreas disponíveis para construção de moradias. Essa situação específica não está presente dentro dos limites da bacia do Mandaqui, mas uma área similar, também alvo do PDE, nos limites dos muros da Invernada da Polícia Militar, impõe pressão às áreas mais altas da bacia.

O Plano Diretor Estratégico, revisado em 2014, seguiu a tendência do PDE anterior em trazer um aporte mais amplo que integra sistema de mobilidade, ocupação do solo e meio ambiente. No entanto, as escalas trabalhadas seguem sendo aquelas políticas e não delimitadas por ecossistemas e processos da paisagem (por exemplo, a bacia hidrográfica) o que torna o aporte ambiental ainda bastante deficitário em detrimento aos outros dois.

Segundo o Plano, a bacia do Mandaqui é dividida em quatro macroáreas: de Estruturação Metropolitana; de Qualificação da Urbanização; de Redução da Vulnerabilidade Urbana e Qualificação Ambiental; e de Controle e Qualificação Urbana e Ambiental. Complementar ao PDE a Lei de Parcelamento, Uso e Ocupação de Solo (LPUOS - Lei no 16.402/2016), delimita uma série de parâmetros urbanísticos a partir das diretrizes expostas pelas macroáreas (Figura 33). A revisão dos planos também trouxe uma contribuição quanto aos processos de participação cidadã e dos distintos setores da sociedade.

A seguir são apresentadas as principais características de cada macroárea e os usos de solo propostos:

- Macroárea de Estruturação Metropolitana: propõe as alterações de uso de solo mais intensivas, nas áreas das planícies aluviais do Tietê, historicamente ocupadas por grandes lotes industriais que vem passando por um processo de desmonte na última década. São priorizados os usos do solo: Zona de Desenvolvimento Econômico- ZDE-2 e Zona Eixo de Estruturação da Transformação Metropolitana, do tipo ZEMP. O primeiro tem como característica o uso industrial, a ser modernizado, e o incentivo a atividades produtivas de alta intensidade em conhecimento e tecnologia e centros de pesquisa aplicada e desenvolvimento tecnológico (PLUOS, 2016). O ZEMP inclui as áreas atualmente ocupadas pelo linhão com o objetivo de traçar aí uma grande 
avenida para apoio a marginal Tietê quanto a conexão oeste-leste. É bastante permissivo quanto a taxa de aproveitamento do lote, (igual a 4) e gabarito sem limite com possibilidade de incorporação de incentivos urbanísticos. Embora seja exigido licenciamento ambiental para aprovação das construções, o único fator limitante a densidade alcançada está vinculada a existência de um sistema de transporte público coletivo já instalado. Não há consideração quanto as questões de paisagem, sejam elas visuais ou da ordem dos processos intrínsecos a ela.

- Macroárea de Qualificação da Urbanização é predominante na bacia e foca sobretudo na melhora das áreas urbanas já consolidadas. São delimitadas Zonas Predominantemente Mistas (ZM-u), com áreas pontuais destinadas a Zonas Especiais de Interesse Social (ZEIS dos tipos 1, 2, 3 e 5) ${ }^{48}$ e Zona Estritamente Residencial (ZER1). Alguns dos principais eixos de mobilidade são diferenciados como Zonas Corredores (ZC), onde o potencial construtivo permitido é maior, a fim de aumentar a densidade ao longo das vias de mobilidade. Especial atenção é dada as avenidas Engenheiro Caetano Álvares, Casa Verde, Imirim, Conselheiro Moreira Barros, Voluntários da Pátria e Direitos Humanos, dentre outras. Essa macroárea também inclui uma Zona Especial de Proteção Ambiental- ZEPAM (Parque Niazi Chohfi).

- Macrozona de Redução da Vulnerabilidade Urbana e Qualificação Ambiental: engloba os setores da subprefeitura Casa Verde- Cachoeirinha indicados com os maiores IPVU (conforme indicado no mapa da Figura 24). Incluem ZEIS do tipo 2 e 5 e ZM-u.

- Macroárea de Controle e Qualificação Urbana Ambiental: pretende garantir a conservação das áreas ao norte da bacia, reduzindo as pressões urbanas adjacentes. Limita as áreas da Invernada da Polícia Militar como ZEPAM e uma área remanescente da Mata Atlântica, nas bordas do Horto Florestal, como Zona Especial de ProteçãoZEP.

\footnotetext{
${ }^{48}$ ZEIS-1- referem-se às áreas ocupadas, até 2015, por favelas, loteamentos e conjuntos irregulares que passarão por processo de urbanização; ZEIS-3- referem-se aos imóveis subutilizados em áreas com toda infraestrutura; ZEIS2 são compostas por lotes e glebas vazias que serão destinadas à construção de Habitações de Interesse Social (HIS) e destinadas ao Mercado Popular (HMP). ZEIS-5- Incorporam lotes e glebas com boa oferta de infraestrutura e que também são destinados a habitações do tipo HIS e HMP (LPUOS, 2016).
} 
Figura 33: Mapa de Zoneamento Urbano.

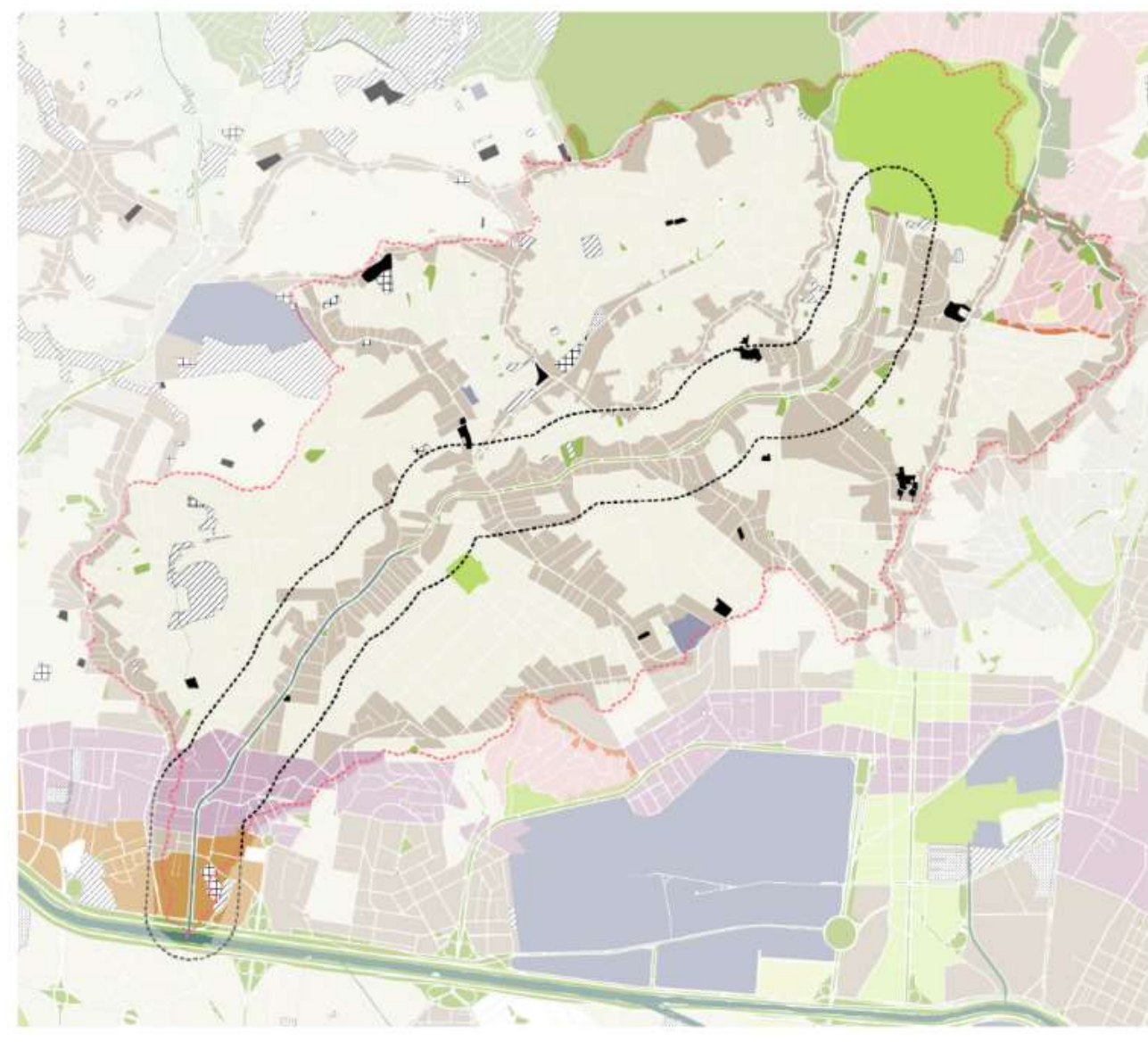

MAPA ZONEAMENTO

Convenções

........ Bacia do Mandaqui

(....... Buffer $300 \mathrm{~m}$

Massa d’água

PC_CANT

ZEPAM

ZEP

IIIIA ZEIS-1

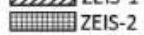

$\square$ ZEIS-3

ZEIS-5

ZC

ZOE

ZER-1

ZCOR-2

ZCOR-1

$2 C^{-a}$

$2 \mathrm{COOB}^{-3}$

ZM_a

SETEMM DE PROSECAO UTM

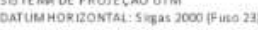

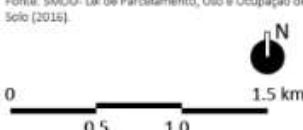

Fonte: elaborado pela autora a partir de LPUOS (2016).

As propostas de mobilidade do PDE são complementadas pelo Plano de Mobilidade Urbana do Município de São Paulo (PlanMob/ SP, 2015), o qual propõe dar prioridade aos pedestres e modos ativos de transporte, integrando o uso de bicicleta aos demais modos de mobilidade urbana, apoiando seus princípios e diretrizes na Política Nacional de Mobilidade Urbana ${ }^{49}$, que por sua vez se baseia nas disposições da Política Nacional da Mobilidade Urbana Sustentável, formulado pelo Ministério das Cidades em 2004, destacando-se:

- A equidade no uso do espaço público de circulação, vias e logradouros;

${ }^{49}$ Lei Federal 12.587/2012. 
- "Aumento da oferta de infraestrutura viária para resolver os problemas da mobilidade não é, a longo prazo, sustentável," (IPEA apud Premissas para um plano de mobilidade urbana, 2012, p. 46) $)^{50}$.

O Plano também cita a UN-HABITAT-2013, quanto a macroestratégias complementares de ação em mobilidade urbana:

“a) redução da necessidade de viagens motorizadas; 2) mudança de viagens para os modos de transporte público coletivo e os ativos; 3 ) utilização de combustíveis mais limpos e a incorporação de tecnologias de controle de emissões e de melhoria da eficiência energética. (UN-HABITAT-2013 apud PlanMob/SP, 2015, p. 61). ${ }^{51}$

O PDE foca na busca por usos mistos do solo e na eficiência da mobilidade, inovando ao relacionar uma rede de transporte público de distintas capacidades ao uso da bicicleta e a estratégias locais para a humanização e ativação do espaço público urbano para usufruto das pessoas. Enfatiza também o adensamento urbano ao longo das avenidas, propondo o aumento da verticalização, a fim de incrementar o número de pessoas numa determinada área de acordo com a potencial oferta de transporte público oferecida por estes eixos de mobilidade. A proposta, tem aporte na lei federal e nos objetivos da UN-HABITAT, conforme descrito acima, e mescla influências de conceitos tais como, Cidade Compacta, Cidade para Pessoas (GEHL, 2010) e a estratégia de Desenvolvimento Orientado ao Transporte Sustentável (DOTS).

Como síntese do que a cidade poderia significar, é promovido um funcionamento urbano mais equilibrado, que, no entanto, oculta um lado perverso ao subestimar uma camada essencial à própria existência e sobrevivência das cidades, a camada ambiental ou ecossistêmica. No Mandaqui, o adensamento proposto ao longo das vias de mobilidade está relacionado tanto a vias em fundos de vale, quanto em áreas de vertentes ou topo de morro, sem que haja consideração das distintas dinâmicas de paisagem associadas a cada um desses compartimentos do relevo (analisados na Parte II- Capítulo 3). A ocupação intensa dos fundos de vale enfatiza a pressão sobre as planícies fluviais, ou seja, justamente sobre as áreas que deveriam receber ações

\footnotetext{
50 IPEA. A Nova Lei de Diretrizes da Política Nacional de Mobilidade Urbana. Comunicados do IPEA n¹28. Brasília: IPEA, 2012.

51 United Nations Human Settlements Programme, 2013.
} 
que focadas na sua conservação e recuperação, atuando como locais estratégicos para a prevenção de riscos de enchentes e adaptação às mudanças climáticas (RODRIGUES, 2015).

Outro ponto da LPUOS que merece ser comentado se refere a Quota Ambiental. O objetivo proposto é fornecer parâmetros para que empreendedores possam incluir elementos de desenho que beneficiem a drenagem, o microclima e a biodiversidade urbana, válido tanto para novas construções quanto para reformas (LPUOS, 2016). A proposta avança em relação as anteriores, ao adicionar um parâmetro ambiental àqueles dedicados exclusivamente à ocupação do lote e densidade construída. Se inicialmente a Quota Ambiental seria válida para todos os tamanhos de lote, durante as discussões da lei acabou condicionada a tamanhos mínimos iguais a $500 \mathrm{~m}^{2}$. Tanto seus critérios quanto o menu de opções fornecido são passíveis de adequações e melhoras e há necessidade de articulação das metas indicadas para a escala do lote às estratégias nas escalas subsequentes, da quadra, bairro, bacia hidrográfica etc. adequando-se às Múltiplas escalas da IEV. Sem essa articulação não é possível vislumbrar o papel de cada lote em alcançar objetivos coletivos, a escalas urbanas ou mesmo desenhar estratégias que possam incentivar os pequenos proprietários a fazer alterações em sua propriedade. O aporte mais efetivo da Quota é o de reforçar a instalação das chamadas piscininhas nos edifícios, como forma de amortecer o impacto das águas durante eventos intensos de chuva e com potencial de associação a sistemas de aproveitamento.

A aprovação dos Planos Regionais Estratégicos, PREs, em 2004, passou a considerar o sistema hídrico urbano como um dos quatro elementos estruturadores do território ${ }^{52}$ e estabeleceu diretrizes pautadas principalmente no tratamento das várzeas a partir da criação de uma série de parques lineares e caminhos verdes (TRAVASSOS, 2010). Alguns desses parques foram instalados a partir de 2007, com diferentes níveis de êxito (ibid). Na bacia do Mandaqui, Caminhos Verdes foram propostos ao longo das avenidas Caetano Álvares e Direitos Humanos e ao longo do córrego Água Preta, próximo ao hospital do Mandaqui, além de acompanhar a instalação das vias de suporte à marginal Tietê, sob o linhão (PRE, 2004a; 2004b). Os novos Planos

\footnotetext{
52 Rede estrutural hídrica ambiental; rede viária estrutural; rede estrutural de transporte público e rede estrutural de eixos e polos de centralidade.
} 
Regionais ${ }^{53}$, delineados a partir da revisão dos anteriores, em 2016, contaram com processos participativos, desenvolvidos em cada uma das prefeituras regionais com a finalidade de compreender as demandas da população. Os Planos da Casa Verde e de Santana/Tucuruvi propõem uma série de ações em perímetros de atuação, muitas delas com impacto direto na bacia do Mandaqui e nas áreas de fundo de vale. Abaixo estão listadas as principais propostas de acordo com cada um dos planos:

Casa Verde:

- Córrego Tabatinguera: Promover a recuperação e conservação ambiental dos cursos d'água e das encostas; qualificação dos espaços livres públicos; implantação de áreas verdes com equipamentos de lazer; recuperação e descontaminação das áreas de nascentes e instalação de infraestrutura de saneamento (manutenção Programa Córrego Limpo); instalação de reservatório de drenagem segundo o Caderno de Bacia Hidrográfica porém, preferencialmente sob área de lazer; Adequação viária, implantação de ciclovias e estruturação do transporte público.

- Conexão Rua Zilda- Escola de Samba Casa Verde (através da av. Eng. Caetano Álvares): redesenho do viário existente e alargamento do leito carroçável para melhor acessibilidade, fruição do transporte coletivo e de pedestres; arborização; contenção de enchentes.

- Avenida Eng. Caetano Álvares (trecho Marginal-Imirim): qualificação e fortalecimento da centralidade linear; implantação de áreas verdes e de lazer pública e melhora das existentes; qualificação da ciclovia (novas travessias, conexões e medidas de segurança); recuperação e despoluição da nascente e do leito do Mandaqui; saneamento ambiental; solucionar pontos de alagamento; mobilização da população a respeito do manejo das águas e dos resíduos sólidos da bacia;

\footnotetext{
${ }^{53}$ Os Planos Regionais estão disponíveis em: <https://gestaourbana.prefeitura.sp.gov.br/marco-regulatorio/planosregionais/arquivos/> Acessado em 03/05/2017.
} 
- Parque Niazi Chohfi (ZEPAM): criação de parque e integração com escolas e ecoponto nas vizinhanças; adequação de rotas de acessibilidade ao novo parque.

- Apoio Norte: melhorar a conexão dos bairros da zona norte; qualificação e fortalecimento de polos e eixos de centralidades; solução para o saneamento e drenagem de acordo com os Planos específicos existentes;

Diversas vezes o documento cita a implantação de “(...) ações de recuperação ambiental e de ampliação de áreas permeáveis e vegetadas nas áreas de fundo de vale e em cabeceiras de drenagem e em planícies aluviais." (PDR, 2016, p. 32 e 38). Essa aproximação ambiental é válida, porém não considera as especificidades de cada um desses compartimentos do relevo em relação às dinâmicas das águas, que exigiriam diretrizes distintas.

Santana/ Tucuruvi:

- Conexão Santana-Mandaqui: melhoria da acessibilidade e qualidade urbana para pedestres e ciclistas; melhorias viárias que priorizem o transporte coletivo; melhoria das áreas verdes e espaços públicos; redesenho das calçadas para continuidade do trajeto, aumento da permeabilidade do solo, arborização etc.

- Hospital do Mandaqui: melhorar a acessibilidade ao hospital; qualificar os espaços públicos vinculados ao equipamento; melhorar circulação de pedestres e bicicletas e as condições de circulação de ônibus.

- Vila Aurora: atendimento às demandas de habitação, equipamentos de educação, assistência social, equipamentos de saúde etc.; melhoria da circulação de pedestres e ciclistas.

- Lauzane Paulista: Fiscalização das construções no entorno de nascentes de córregos e monitoramento, recuperação e conservação ambiental dos cursos d’água; redesenho de calçadas e instalação de travessias seguras e acessíveis; instalação de ZEIS e equipamentos públicos.

Quanto ao manejo das águas, as diretrizes municipais são guiadas pelo Plano Diretor de Macrodrenagem do Alto Tietê $\hat{e}^{54}$. Um dos principais aportes recentes da Prefeitura Municipal de

\footnotetext{
${ }^{54}$ PDMAT3 a cargo do Departamento de Água e Energia Elétrica- DAEE- do Governo de São Paulo.
} 
São Paulo, foi o desenvolvimento do Manual de Drenagem e Manejo das Águas Pluviais (PMSP, 2012). Composto por três volumes, o manual, dentre as estratégias tradicionais de drenagem, apresenta possibilidades de manejo das águas urbanas a partir da utilização de tecnologias baseadas nas Melhores Práticas de Manejo- MPM- (Best Management Practices in Urban Drainage and Flood Control District, 1992 apud PMSP, 2012, volume II, p. 75) ${ }^{55}$, introduzindo conceitos de drenagem sustentável e da retomada de processos naturais para cuidar das águas de chuva. Cita a importância das áreas verdes urbanas para a retenção da contaminação por cargas difusas, controle de vazões, volumes e cargas de sedimentos e indica a possibilidade de utilização das MPM, tais como faixas e valetas gramadas, bacias de detenção (vegetadas) secas e alagadas e alagadiços (wetlands). Embora não cite o termo Infraestrutura Verde, tais estratégias vão de encontro ao princípio de Integração Verde-cinza (azul) (ver Parte I- Capítulos 1 e 5). A elaboração do Manual foi liderada pela Secretaria Municipal de Desenvolvimento Urbano - SMDU e contou com a colaboração da Secretaria Municipal de Infraestrutura Urbana e Obras - SIURB, Secretaria Municipal de Coordenação das Subprefeituras - SMSP, Secretaria Municipal de Habitação - SEHAB e da Secretaria Municipal do Verde e do Meio Ambiente - SVMA. A articulação de distintas secretarias é bastante positiva para uma visão mais holística e integrada de planejamento urbano.

Atualmente, a SMDU vem desenvolvendo os Cadernos de Bacia Hidrográfica, com objetivo de propor alternativas para a redução de riscos para 28 bacias prioritárias do município de São Paulo. Um dos primeiros cadernos desenvolvidos, foi o do Mandaqui, em 2016.

No Caderno são apresentadas duas alternativas estruturais para solucionar o impacto das chuvas com período de retorno de 100 anos e duas intervenções não estruturais com foco em chuvas de TR até 25 e 100 anos. Tanto as alternativas quanto as intervenções consideram a instalação de reservatórios de grande capacidade, os piscinões (reservatórios off-line), e duas opções também sugerem um parque linear desenhado como reservatório in-line. Os reservatórios off-line são aqueles localizados fora do curso d'água enquanto os reservatórios inline são localizados ao longo do curso d'água, tendo uma capacidade de armazenamento menor que os primeiros. A Alternativa 1 conta com três piscinões, somando a reservação de $252.000 \mathrm{~m}^{3}$,

\footnotetext{
${ }^{55}$ Urban Drainage and Flood Control District, Urban Storm Drainage Criteria Manual Volume 3, 2015.
} 
reforços de galerias, canalização parcial do Tabatinguera e instalação de Parque Linear em afluente do Lauzane (Figura 34). A Alternativa 2, considera dois reservatórios, somando 152.000 $\mathrm{m}^{3}$ de reservação, os mesmos reforços de galeria e canalização parcial do Tabatinguera, mas exclui o parque linear e inclui o rebaixamento de fundo (entre 3,75 e 4m), remoção das entroncas e revestimento do canal do Mandaqui inferior, seguindo as diretrizes propostas pelo PDMAT3, (SIURB, 2016)(Quadros 9 e 10). Os piscinões propostos ao longo das avenidas Direitos Humanos e Engenheiro Caetano Álvares e do córrego Tabatinguera tem profundidades aproximadas de $23 \mathrm{~m}, 20 \mathrm{~m}$ e $14 \mathrm{~m}$ respectivamente. Mesmo com as estratégias paisagísticas instaladas, estas estruturas impactarão a paisagem como enormes crateras de concreto, secas durante grande parte do ano.

Figura 34: Expressão paisagística do parque linear Lauzane (esq.) e piscinão (dir.)
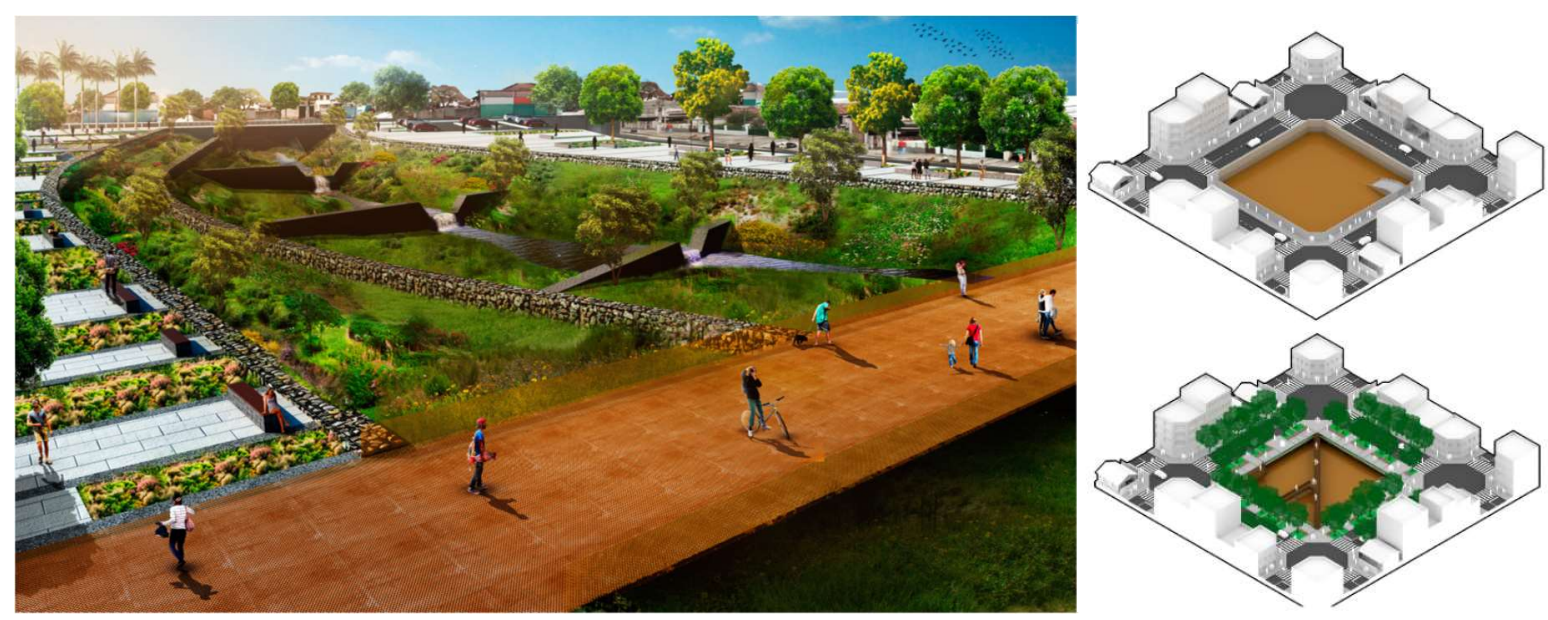

Fonte: gentilmente fornecidas pela SIURB.

Quadros 9 e 10: Alternativas (esq.) e Intervenções (dir.) sugeridas pelo Caderno.

\begin{tabular}{|c|c|c|c|c|c|}
\hline Localização & Alternativa 1 & Alternativa 2 & Localização & Intervenção 1 & Intervenção 2 \\
\hline Mandaqui Superior & $\begin{array}{c}\text { Reservatorio } \\
\text { Reforço de galeria }\end{array}$ & Reforço de galeria & Mandaqui Superior & $\begin{array}{l}\text { Reservatório } \\
\text { Reforço de galeria }\end{array}$ & $\begin{array}{c}\text { Reservatório } \\
\text { Reforço de galeria }\end{array}$ \\
\hline Mandaqui Médio & Reforço de galeria & Reforço de galeria & & & \\
\hline Lauzane & $\begin{array}{l}\text { Reservatório } \\
\text { Parque linear }\end{array}$ & Reservatorio & Mandaqui Médio & $\begin{array}{c}\text { Zona de inundação } \\
\text { (TR } 25 \text { anos) }\end{array}$ & $\begin{array}{l}\text { Zona de inundação } \\
\text { (TR } 10 \text { anos) }\end{array}$ \\
\hline Tabatinguera & $\begin{array}{l}\text { Reservatório } \\
\text { Canalização }\end{array}$ & $\begin{array}{l}\text { Reservatório } \\
\text { Canalização }\end{array}$ & Lauzane & $\begin{array}{c}\text { Zona de inundação } \\
\text { (TR } 25 \text { anos) }\end{array}$ & $\begin{array}{c}\text { Parque linear } \\
\text { Zona de inundação } \\
\text { (TR } 10 \text { anos) }\end{array}$ \\
\hline Mandaqui Inferior & - & $\begin{array}{l}\text { Rebaixamento de fundo, } \\
\text { remoçăo das estroncas e } \\
\text { revestimento do canal }\end{array}$ & Tabatinguera & $\begin{array}{l}\text { Zona de inundação } \\
\text { (TR } 25 \text { anos) }\end{array}$ & $\begin{array}{l}\text { Zona de inundação } \\
\text { (TR } 10 \text { anos) }\end{array}$ \\
\hline
\end{tabular}

Fonte: gentilmente fornecidos pela SIURB. 
No Caderno da bacia do córrego Mandaqui, os piscinões ainda são tratados de modo bastante tradicional, embora haja um esforço tímido de incluir jardins de chuva que "verdejam" suas bordas. Por outro lado, as Intervenções sugeridas apontam uma direção inovadora considerando o histórico de obras urbanas de São Paulo, quanto a alteração de modelos de repúdio e medo das águas de chuva à aceitação das águas durante as inundações. Estas são medidas não estruturais que propõem a demarcação de zonas de inundação para chuvas de TR até 25 anos para serem incorporadas aos planos que regem o uso e a ocupação de solo da cidade, associados a um sistema de alertas. Volumes maiores que estes seriam manejados pelos piscinões tradicionais (SIURB, 2016).

Quanto à qualidade das águas do Mandaqui, o Programa Córrego Limpo foi responsável por praticamente eliminar todas as ligações clandestinas de esgoto da bacia. Desenvolvido em parceria pelo governo do Estado de São Paulo, através da Sabesp, e a prefeitura do Município de São Paulo, o Programa funcionou de 2007 a 2012, sendo retomado em 201756. A meta estabelecida é alcançar a qualidade de água 'Classe 3', seguindo a resolução 537/2005 do CONAMA, e que permite a recreação de contato secundário com as águas, além das condições estéticas e odoríficas ideais para a retomada do convívio da população com as águas urbanas. A remoção das cargas poluentes difusas não são objetos do Programa, mas estratégias de educação ambiental da população estão previstas, focadas sobretudo no entendimento do impacto que o despejo irregular de resíduos sólidos causa aos córregos e consequentemente a qualidade de vida dessas pessoas.

O Programa prevê o mapeamento dos pontos de deságue de esgotos e a proposição de infraestrutura para a coleta e afastamento das águas residuais a fim de reduzir a Demanda Biológica de Oxigênio (DBO), associada principalmente às cargas de esgoto doméstico despejadas diretamente nos corpos d'água. A Sabesp tem a responsabilidade de instalar a infraestrutura sanitária, monitorar a qualidade das águas e conscientizar a população local ${ }^{57}$ e o município deve

\footnotetext{
${ }^{56}$ No início de 2017 o Programa foi retomado, com contrato firmado até o ano de 2039. Disponível em: <http://www.prefeitura.sp.gov.br/cidade/secretarias/meio ambiente/noticias/?p=235610>, Acessado em 23/10/2017.

${ }^{57}$ Disponível em: <https://www.diariozonanorte.com.br/a-volta-do-programa-corrego-limpo-com-apoio-dasabesp/> em 07/01/2019.
} 
remover e reassentar famílias que vivem em áreas de risco, implantar parques lineares além de destinar as Prefeituras Regionais a responsabilidade de limpeza das margens dos córregos, a manutenção das galerias de águas pluviais e bocas de lobo, e a verificação de possíveis ligações irregulares (SABESP, 2012).

Na bacia do córrego Mandaqui o Programa atuou com sucesso em cerca de 7,5 km do próprio Mandaqui e em mais $33 \mathrm{~km}$ de seus afluentes (PMSP, 2017). Como consequência, a medição da DBO em dois pontos do córrego Mandaqui, baixou de 240 mg/l para 28 mg/l e de 109 mg/l para 29 mg/l respectivamente, no período de setembro de 2011 a agosto de 2014 (Sabesp, 2014). As sub- bacias dos afluentes do Mandaqui limpos pelo Programa, podem ser vistas na Figura 35.

Figura 35: sub-bacias alvo do Programa Córrego Limpo

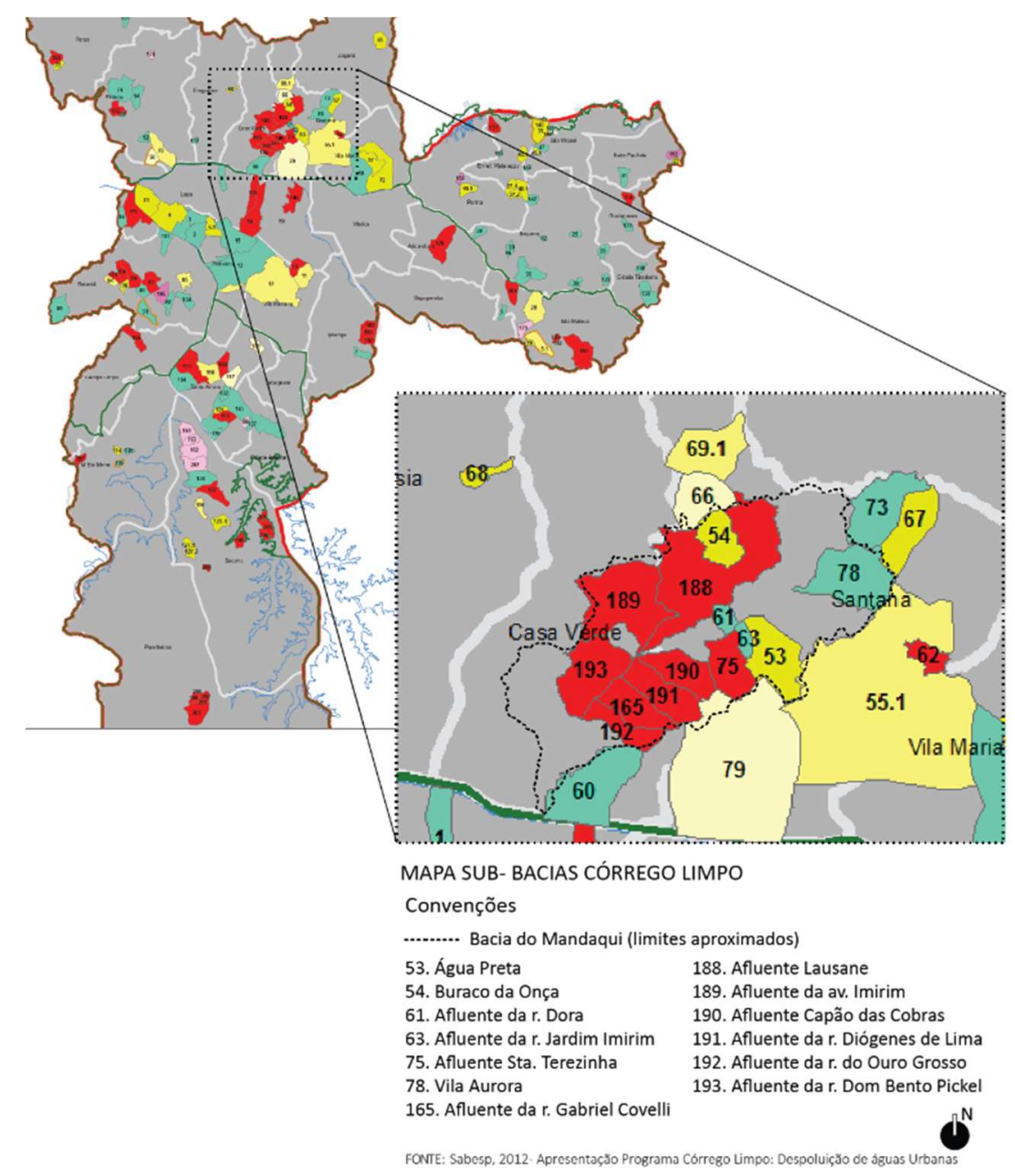

Fonte: elaborado pela autora a partir de Sabesp (2012). 
Com a retirada dos volumes de esgoto dos córregos da bacia, os volumes de base do córrego Mandaqui também foram alterados e em épocas de seca o profundo canal de concreto fica evidente na paisagem (Figura 36). Os poucos córregos em estado natural e acessíveis são provavelmente aqueles mais notados pela população, uma vez que surpreendem pela água transparente a falta de odor (Figura 39). Em outros pontos da bacia, a solução técnica utilizada foi a instalação de tubos externos dentro dos córregos em estado natural (Figuras 37 e 38), sem nenhuma preocupação paisagística. Alguns desses córregos estão confinados entre muros de edifícios e atuam como uma vala de servidão, praticamente sem acesso. Outros, poderiam voltar a fazer parte da paisagem, com frentes de lotes ou acessos e rotas ao longo de pequenos parques lineares, e funcionariam também como estratégia de reaproximação das pessoas aos cursos d’água da bacia.

Figura 36, 37, 38 e 39: respectivamente, porção de canal aberto da córrego em calha de concreto, na altura da av. Casa Verde (esq.); tubos de coleta de esgoto residencial ao longo dos córregos afluentes do Mandaqui (centrais); Porção de córrego (Água Preta) aberto natural.
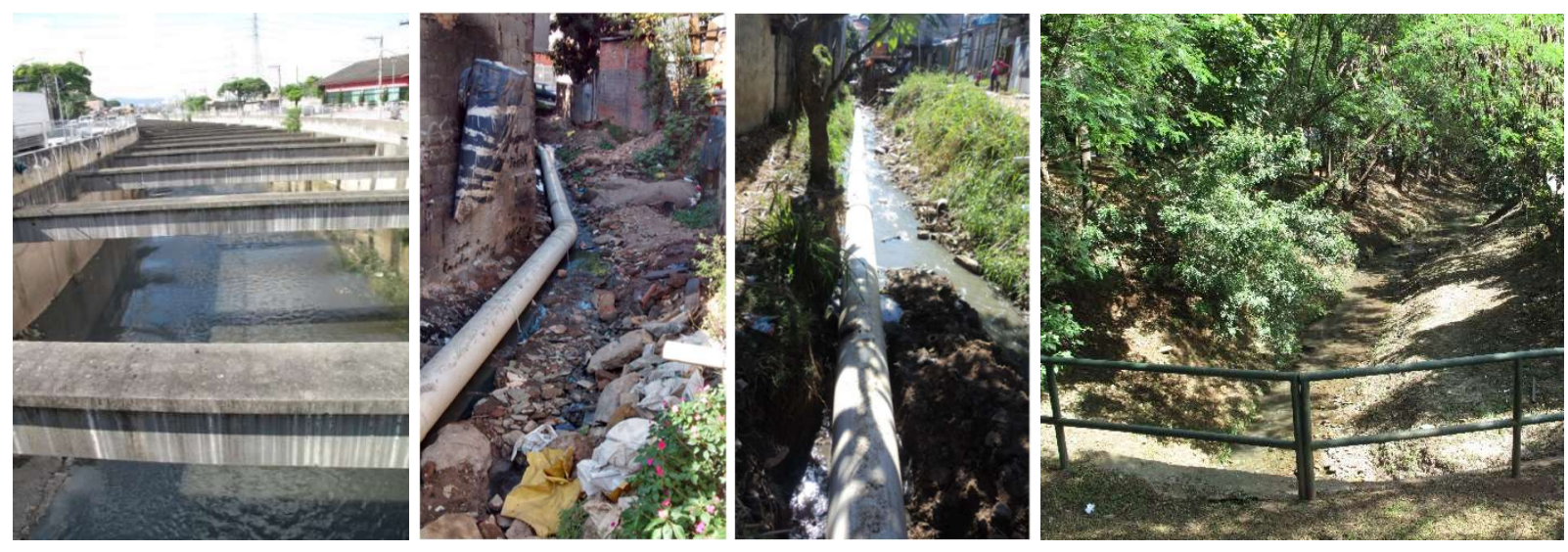

Fonte: figuras 36 e 39, autora, 2016; figuras 37 e 38, Sabesp (2017).

Finalmente, vale citar o Plano Intensivo de Manejo Arbóreo (PIMA; SVMA, 2015) proposto em 2015 como forma de atender à demanda emergencial de podas e remoções de árvores, especialmente em oito prefeituras onde a situação é mais crítica. O PIMA não incorpora estratégias amplas de manejo, que compreendam o plantio, acompanhamento e substituição das espécies ao longo do tempo, um Plano de manejo de toda a Floresta Urbano ainda é necessário. 


\section{COMPARTIMENTAÇÃO DA PAISAGEM DO MANDAQUI}

Conforme descrito no subcapitulo 4.1- Parte I, a compartimentação da paisagem será elaborada na escala da bacia do Mandaqui, tendo como um de seus recortes, ou compartimentos estruturantes, o fundo de vale. Adicionalmente à aplicação do método a tese propõe relacionar os Compartimentos Estruturantes da Paisagem à gama de Espaços Abertos encontrados na bacia, às tipologias de LID apresentadas e aos Serviços Ecossistêmicos que potencialmente poderão fornecer.

\subsection{COMPARTIMENTOS DO RELEVO E ESTRUTURAS SUPERFICIAIS}

Os estudos de Ab'Saber partem de distintas seções geológicas em escalas regionais e locais, elaboradas por cientistas anteriores a ele ou como fruto de seu trabalho. A partir da análise do contexto geológico da cidade de São Paulo, entre as áreas da Serra da Cantareira e o Maciço de Santos (Figura 40) e do diagrama esquemático da planície do Tiete e Serra da Cantareira (Figura 41), é possível localizar as áreas do Mandaqui predominantemente nas porções de terraços, colinas e outeiros, e ao longo das planícies do Tietê.

Figura 40: Seção geológica da Serra da Cantareira ao Maciço de Santos.

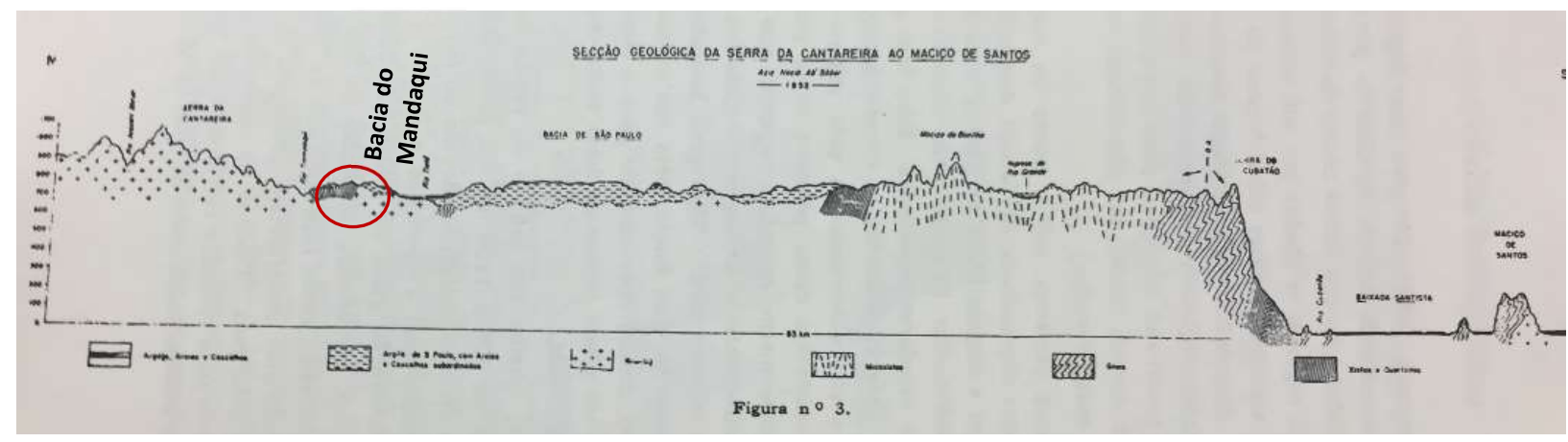

Fonte: elaborado pela autora a partir de $A b^{\prime}$ Saber (2007, p.68). 
Figura 41: Bloco Diagrama Esquemático das formas do relevo da Planície do Tietê à Serra da Cantareira (10,5km).

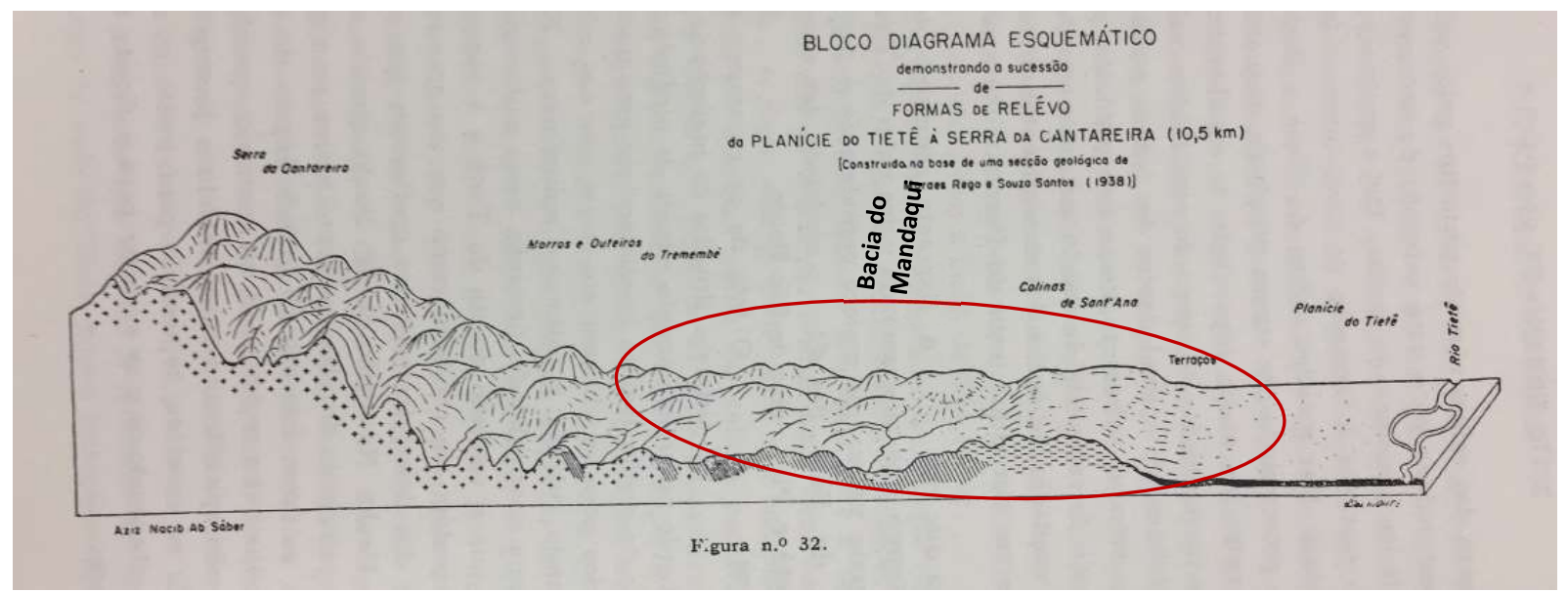

Fonte: elaborado pela autora a partir de Ab' Saber (2007, p. 282).

As várzeas do Tietê são compostas por planícies fluviais com cursos originalmente meandricos que se estendiam também ao longo do rio Pinheiros e se caracterizavam pela presença de uma série de formações típicas dos processos dinâmicos hidrológicos, tais como diques, faixas de cinturões meandricos, bacias de decantação, planície de inundação e crevasses (RODRIGUES, 2015). Essas características, embora bastante afetadas pela urbanização, seguem influenciando as áreas do curso inferior do Mandaqui e conformam o compartimento topográfico da Planície Aluvial e Baixos Terraços do Tietê com variação de altura entre as cotas 720 m e 730 m. Também incluem-se nessas cotas as Planícies Aluviais do Mandaqui, que compreendem os fundos de vale do córrego principal e de seus afluentes, podendo, nesse caso, chegar até $750 \mathrm{~m}$ de altura devido a presença de vales localizados em porções mais elevadas do relevo. Finalmente, as Colinas e Outeiros variam suas cotas entre $750 \mathrm{~m}$ a $828 \mathrm{~m}$ e são caracterizados por forte irregularidade no relevo, típicas das vertentes da Cantareira, com cotas bastante variadas.

A relação entre os compartimentos Planície Aluvial do Mandaqui e Colinas e Outeiros, fica evidente na Seção Geológica entre Santa Terezinha e Vila Mazei, apresentada na Figura 42, e no Esboço Geológico do Bairro da Casa Verde e Vizinhanças, Figura 43. Nas figuras, é possível observar a rápida transição entre estas formas do relevo, em direção oeste-leste, passando de cotas próximas a 725 m, no vale do Mandaqui, a alturas que beiram os 800 m, nas imediações da atual av. Casa Verde (antiga estrada de Sant'Anna). 
Figuras 42 e 43: Secção geológica entre Santa Terezinha e Vila Mazei (esq.) e esboço geológico do bairro da Casa Verde e vizinhanças (dir.)
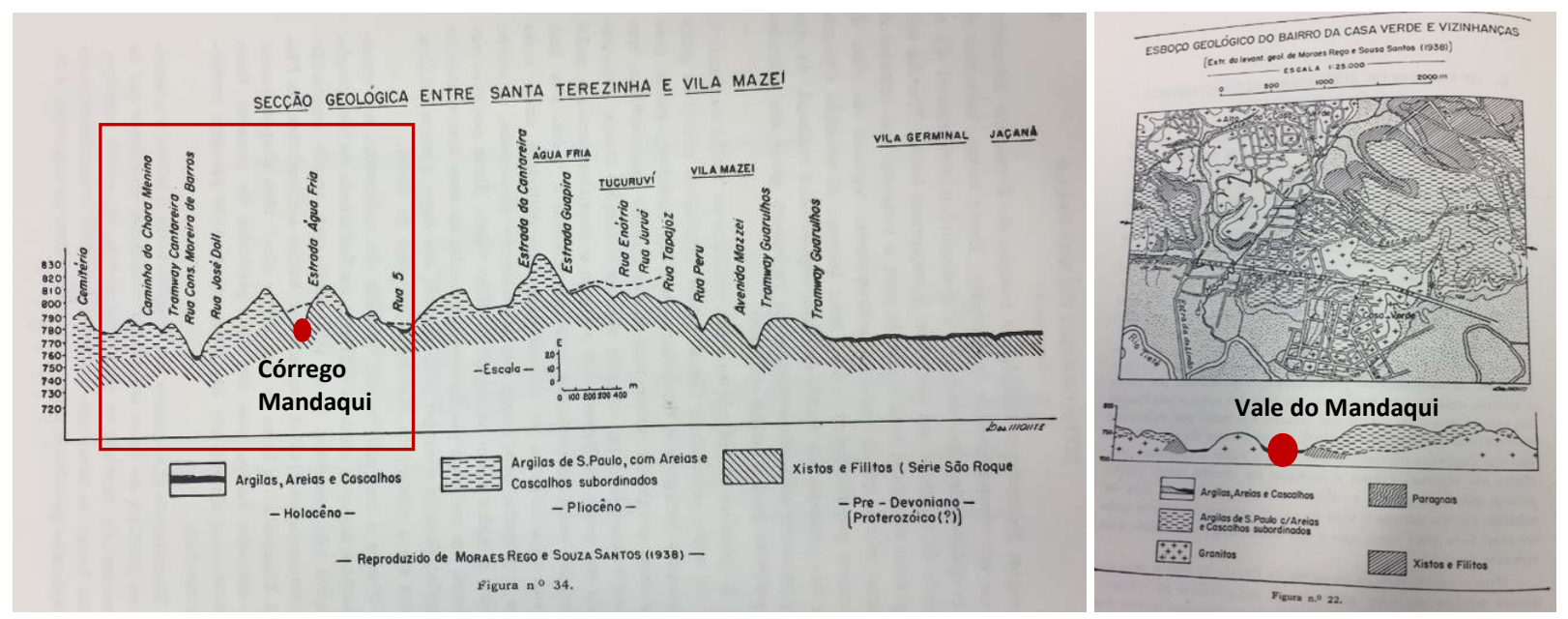

Fonte: elaborado pela autora.a partir de Ab' Saber, (2007, p. 284 (esq.) p. 166 (dir.)

À compartimentação topográfica foram adicionados dados referentes à inclinação do terreno, (gerado em SIG segundo as faixas de declividade: 0-5\%; 5-0\%; 10-20\%; > 30\%), à suscetibilidade quanto aos movimentos de massa e inundações, às formações geológicas, à drenagem e às áreas contaminadas ${ }^{58}$, fornecendo assim, o respaldo necessário para a identificação das estruturas de paisagem e dos processos associados a elas, com enfoque principal nas dinâmicas hidráulicas. Inicialmente foram diferenciados os cursos superior, médio e inferior do Mandaqui (a partir do Mapa Digital do Terreno), ${ }^{59}$ e as áreas indutoras ou receptoras de processos, representadas respectivamente pelos divisores de águas e fundos de vale da bacia, além das áreas de vertentes, conectoras das duas primeiras, e que podem ser caracterizadas tanto como receptoras quanto transmissoras ou indutoras de processos devido às altas declividades que apresentam.

\footnotetext{
${ }^{58}$ Cartas de Suscetibilidade (IPT, 2015); Carta Geotécnica (SMDU, 2000); Áreas Contaminadas (SVMA, 2015), Drenagem (2004). Disponíveis em:< www.geosampa.sp.gov.br/PaginasPublicas/ SBC.aspX>, Acesso em: 10/06/2016.

${ }^{59}$ O MDT permite identificar as áreas mais ou menos altas da bacia e representa a variação da elevação do terreno a partir do qual será possível definir intervalos de inclinação da superfície e gerar mapas de declividades definidas segundo intervalos fixos. Elaborado a partir da carta de hipsometria (MDC, 2004), Disponível em: $<$ www.geosampa.sp.gov.br/PaginasPublicas/ SBC.aspx > Acesso em: 10/06/2016.
} 
O curso superior é caracterizado por concentrar a maioria das nascentes dos contribuintes do Mandaqui (à exceção do córrego Tabatinguera). Possui vales acentuados e inclinados muitas vezes configurados como anfiteatros, colaborando para o aumento da velocidade das águas e a ação de desgaste do solo. O curso médio tem início nas proximidades do encontro entre os córregos Mandaqui e Lauzane e é caracterizado por vales em " $\mathrm{V}$ " abertos e de menor declividade, favorecendo a redução da velocidade das águas e o transporte dos sedimentos desgastados no primeiro trecho. Essa é uma área naturalmente crítica quanto às inundações pois recebe grandes volumes de água e sedimentos das porções superiores da bacia e, por ser uma área muito mais plana do relevo, tende a concentrá-los. Já no curso inferior prevalecem os vales aluviais bastante amplos e com baixas declividades que resultam na diminuição da velocidade das águas e na ação predominante de acumulação de sedimentos, também influenciados pelos processos do rio Tietê (Figura 44).

Figura 44: Mapa Digital do Terreno e indicação das porções superior, média e inferior da bacia do córrego Mandaqui.

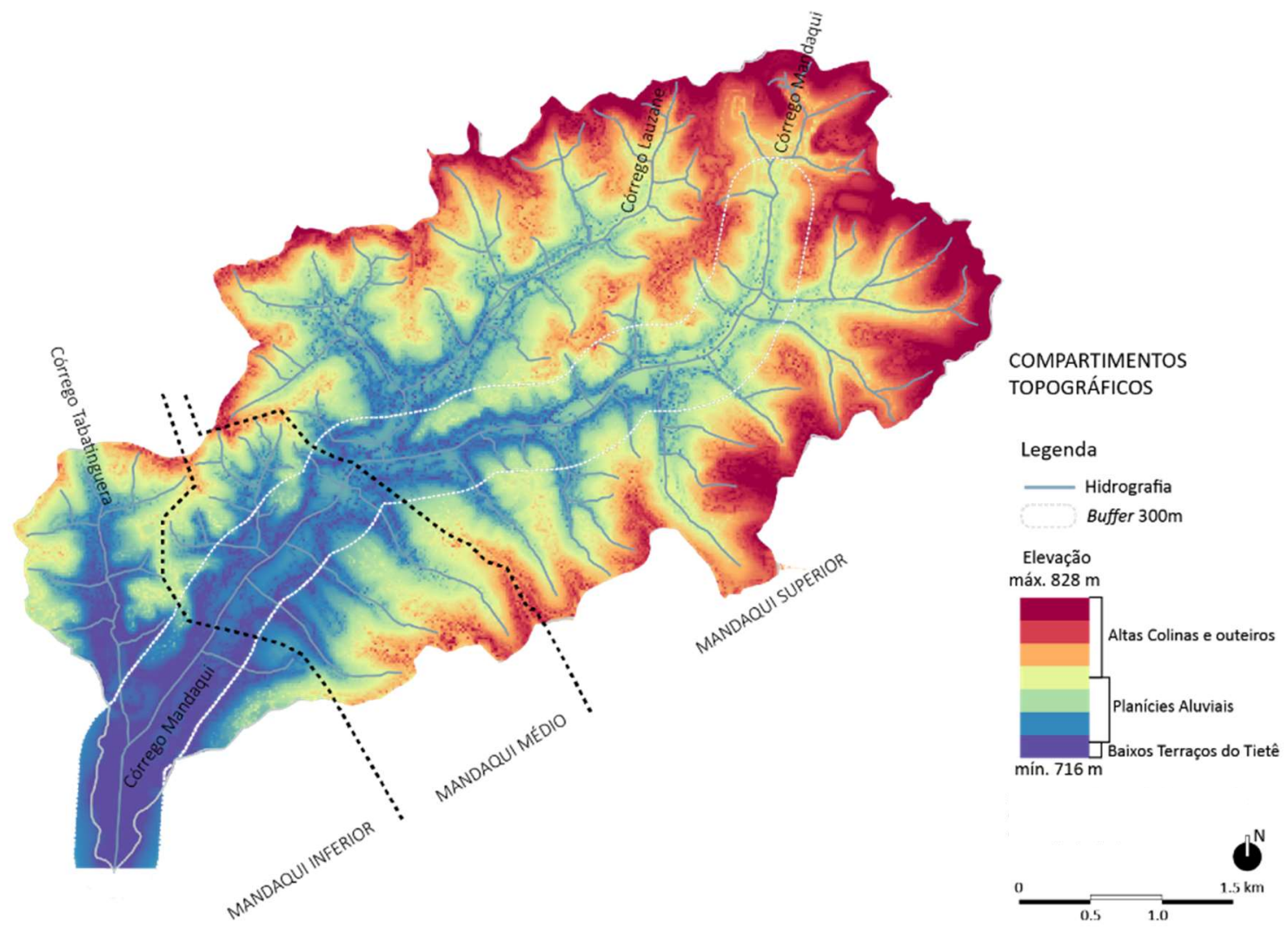

Fonte: elaborado pela autora. 
Uma área buffer de $300 \mathrm{~m}$ foi delimitada a partir da avenida de fundo de vale, como área de influência da via indicada no Plano Diretor Estratégico do município de São Paulo (PDE, 2014), e passou a ser referência para as análises da bacia do Mandaqui. Foram elaborados cortes topográficos gerais da situação atual da bacia, considerando-se o relevo e a posição dos córregos, conforme pode ser visualizado na Figura 45. Enquanto os cortes 1 e 2 apresentam largas porções quase planas que mesclam as Planícies Aluviais do Tietê às do Mandaqui, os cortes 3 e 4 explicitam a influência das Altas Colinas e Outeiros típicos da Cantareira e sua mudança abrupta de topografia a partir das Planícies. O corte 3 apresenta uma área de transição que conta tanto com inclinações típicas das Planícies Aluviais quanto com pequenos morros onde se encontram as nascentes do córrego Tabatinguera. Já o corte 4, tem como característica uma larga área de baixa inclinação do relevo, referente à zona de encontro dos córregos Lauzane e Mandaqui (Figura 46).

Figura 45: Cortes Topográficos da bacia do Mandaqui.

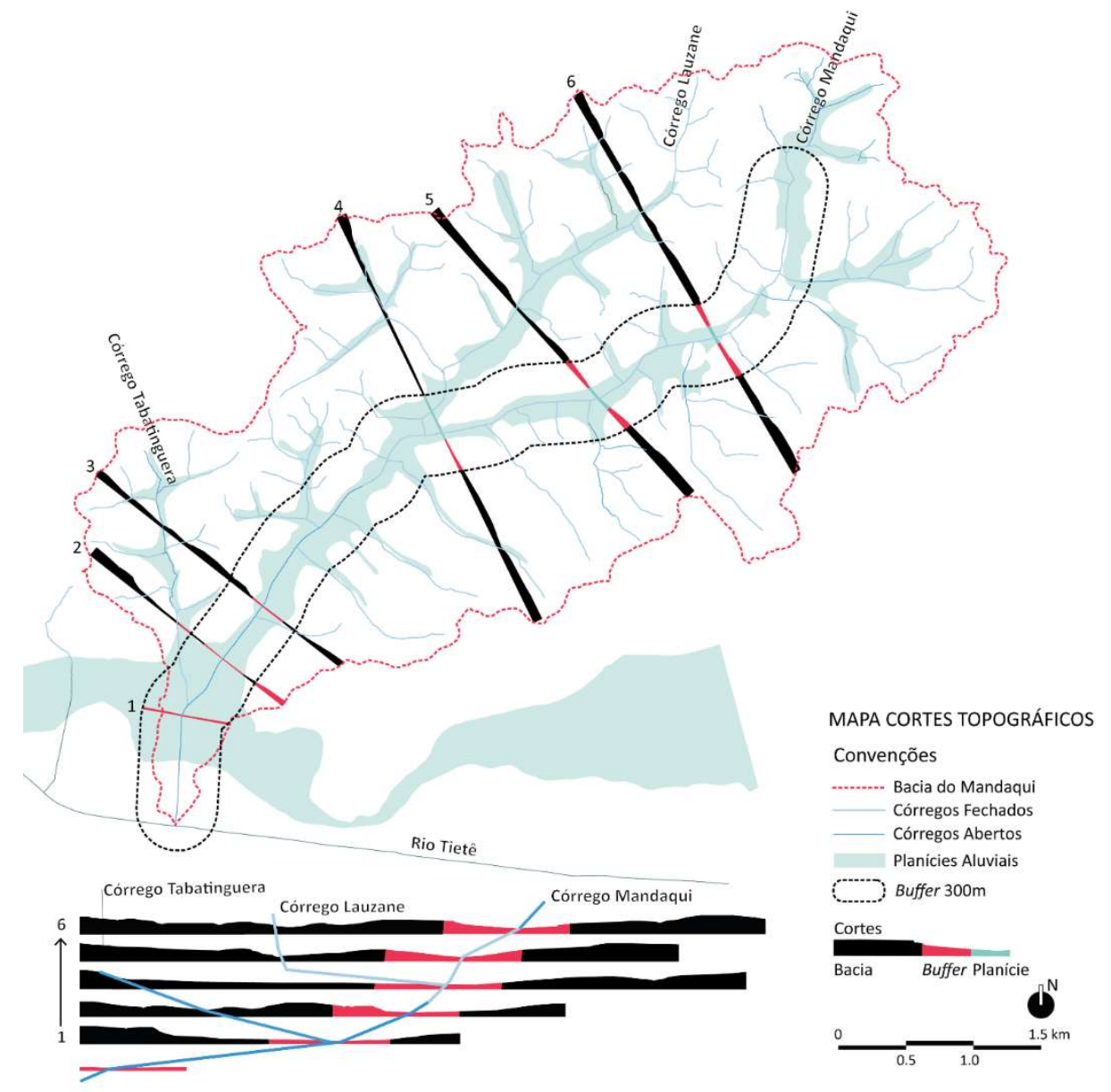

Fonte: elaborado pela autora. 
Figura 46: Cortes ao longo do fundo de vale.
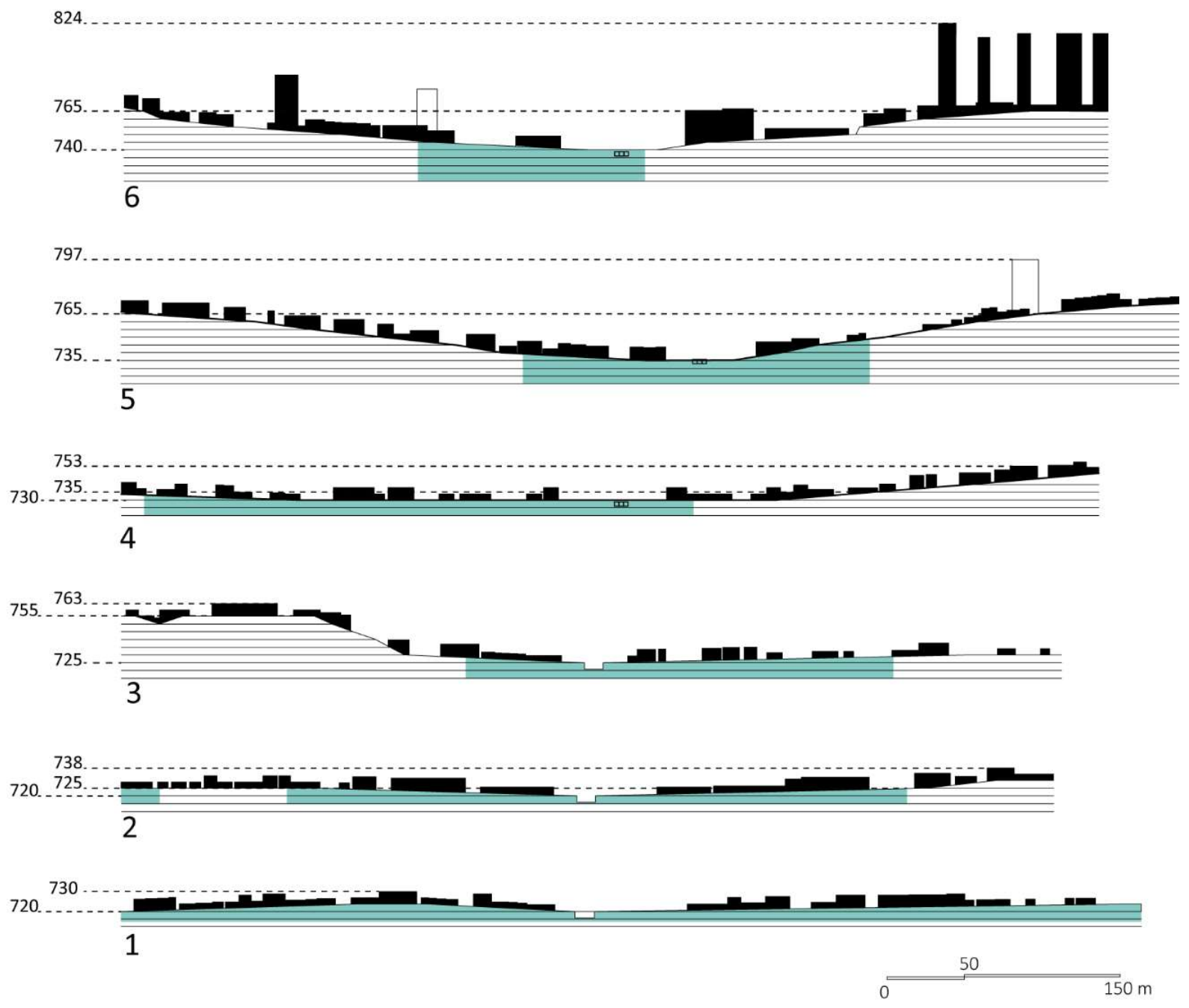

Fonte: elaborado pela autora.

As condições geotécnicas da Bacia do Mandaqui são caracterizadas por formações geológicas de planícies aluviais, solos arenosos e argilosos, pela presença de sedimento terciário e áreas de xisto micáceo e granitoides ${ }^{60}$ que variam nos diferentes compartimentos do relevo. Quanto à suscetibilidade, são identificadas três áreas de atenção, uma próxima ao limite da várzea do córrego Lauzane, com risco de escorregamento, e outras duas ao longo das planícies do córrego Tabatinguera, onde há risco de solapamento justamente em áreas ocupadas

${ }^{60}$ Dados coletados a partir da Carta Geotécnica do município (1993). 
irregularmente por favelas. Outras faixas com risco médio de movimento de massas estão dispostas em distintas porções da bacia, em sua maioria relacionadas às altas declividades. É possível então delimitar sub-compartimentos topográficos com características similares quanto a seu relevo, mas que podem conter estruturas superficiais e processos variados, conforme segue:

Altas Colinas e Outeiros (750 até 828 m)

O extremo norte da bacia, nas imediações da Serra da Cantareira, é caracterizado por fortes declividades e predominância de solos areno-argilosos que possuem maior potencial para a infiltração das águas de chuva e lençol freático cerca de $8 \mathrm{~m}$ abaixo da superfície (SCHUTZER, 2019), garantindo nesta área uma boa percolação da água infiltrada, mas sendo caracterizada também pelo potencial médio e alto de movimento de massas, responsáveis pelos processos de erosão e escorregamento de taludes e aterros (IPT, 2015) ${ }^{61}$. Esse compartimento topográfico possui declividade variada e abriga processos distintos relacionados à estrutura da paisagem. Dessa forma pode ser subclassificado em: Nascentes e Anfiteatros; Áreas íngremes das Vertentes e; Terraços das Altas Colinas e Outeiros.

- Nascentes e Anfiteatros

Associados às áreas mais elevadas das Altas Colinas e Outeiros se encontram muitas das nascentes e anfiteatros do Mandaqui e de seus afluentes, bastante encaixados no relevo em meio a altas declividades, (normalmente acima de $30 \%$ e podendo chegar a inclinações superiores a 60\%). São áreas com suscetibilidade ao movimento de massas, (erosões), devido tanto às grandes inclinações das encostas e anfiteatros quanto às formações de xistos- micáceos e granitoides. São

\footnotetext{
${ }^{61}$ O IPT utiliza cartas na escala 1:25000, portanto dentro das zonas delimitadas com suscetibilidade alta, média ou baixa podem haver áreas com classes distintas. Nos terrenos, a transição entre as classes tende a se apresentar de modo mais gradual. "Estudos mais detalhados em nível local são necessários, particularmente em áreas de suscetibilidade alta e média, podendo produzir limites distintos ante os apontados na carta. Nas áreas urbanizadas/edificadas, ressalva-se o fato de que as classes indicadas podem estar alteradas, para mais ou para menos, a depender do grau de influência da ocupação existente." (IPT, metadados da Carta de Suscetibilidade, 2015).
} 
portanto, áreas indutoras de processos, caracterizadas pela ação de desgaste feita pelos córregos encaixados no relevo, favorecendo o escoamento superficial (Figura 47).

\section{- Áreas íngremes das Vertentes}

São estas as áreas que conectam as Planícies Aluviais aos topos ou terraços das Altas Colinas. Predominantemente formadas por zonas com inclinação superior a $20 \%$, variam a altura topográfica entre 750 m e 828 m. São responsáveis por gerar impactos à jusante, devido às altas velocidades das águas que escoam superficialmente, ao mesmo tempo, são impactadas pelas porções superiores da bacia, favorecendo a ocorrência, com risco médio e alto, de movimentos de massa. Representam, portanto, áreas críticas da paisagem, responsáveis pelo amortecimento da velocidade e volume das águas de chuva a fim de reduzir seus impactos a jusante. As Áreas íngremes das Vertentes são predominantes na Bacia do Mandaqui.

- Terraços das Altas Colinas e Outeiros

Em meio ao relevo bastante inclinado das Altas Colinas e Outeiros é possível delimitar porções de terraços de declividades mais amenas, variando entre 0-10\%, que podem estar ou não conectados como uma sequência de topos de colinas ao longo da bacia. Possui áreas compostas por granitoides, com textura argilo- arenosa e bom potencial para a infiltração das águas de chuva, favorecido pelas baixas declividades e pela localização do lençol freático a cerca de $8 \mathrm{~m}$ abaixo da superfície, garantindo nesta área uma boa percolação da água infiltrada (SCHUTZER, 2019). Já as áreas compostas por xistos- mircáceos favorecem o escoamento das águas e, por sua textura espessa e suscetível a movimento de massas, se caracterizam por processos de erosão, escorregamento de taludes e aterros (IPT, 2015). Finalmente, as áreas compostas por sedimentos terciários possuem como característica sua predominância argilosa e espessa, que favorecem o escoamento superficial em relação aos demais processos hidrológicos.

Fundo de vale (720- $750 \mathrm{~m})$

Mesmo com cotas de grande variação, entre 720 e 750 m, o fundo de vale do córrego Mandaqui é composto pelas porções mais planas do relevo, predominando sua inclinação entre 
0-5\%, mas com variações que podem chegar a 10\%. Apesar de concentrar áreas bastante similares quanto ao relevo e estruturas superficiais, é possível identificar áreas com distintos riscos de inundação e aquelas que sofrem ou não influência direta das variações de caudal do rio Tietê. No fundo de vale é possível identificar a seguinte distinção de relevo e processos:

- Planícies aluviais e Baixos Terraços do Tietê e Pinheiros e seus afluentes principais (720- 725m)

Representam parte do curso inferior do córrego Mandaqui, influenciado pela planície aluvial do rio Tiete, com declividades baixas entre 0-5\%; são áreas onde há dificuldade de manter o escoamento superficial (devido à declividade), característica que torna a área sujeita a inundações, com limitados índices de infiltração de água e sujeita a recalques que podem danificar pavimentos, redes de infraestruturas e edificações, além de estarem sujeitas a inundação (baixa, média ou alta suscetibilidade) (IPT, 2015). Caracterizadas por solos arenosos e argilosos e com lençol freático variando entre 0,5 e 3,00m de profundidade, (SCHUTZER, 2019), são áreas onde o armazenamento de água predomina à infiltração.

- Áreas Tabulares livres de inundação (725-730m)

São áreas com declividades amenas, até 10\%, localizadas entre as Planícies Aluviais e as Áreas íngremes das Vertentes. Embora livres de inundação, essas áreas são receptoras dos impactos provenientes das áreas mais altas do relevo. Sua função principal é amortecer o impacto das águas que chegam até a área e conduzi-las até a planície aluvial. Á distinção das sub-bacias do Tietê localizadas à sua margem esquerda, as áreas tabulares da bacia do Mandaqui possuem dimensões muito restritas, o que limita a ocupação do solo da bacia em zonas mais planas e livres de inundação. Nessas porções predominam solos mais argilosos e espessos do que aqueles das Altas Colinas, responsáveis por um aumento potencial do escoamento superficial e dificuldades para cortes de terreno (SCHUTZER, 2019). São áreas onde o armazenamento de água predomina à infiltração (devido ao lençol freático alto) e ao escoamento superficial (pelas baixas declividades). 
Figura 47: Mapas de Compartimentos Topográficos e estruturas superficiais.

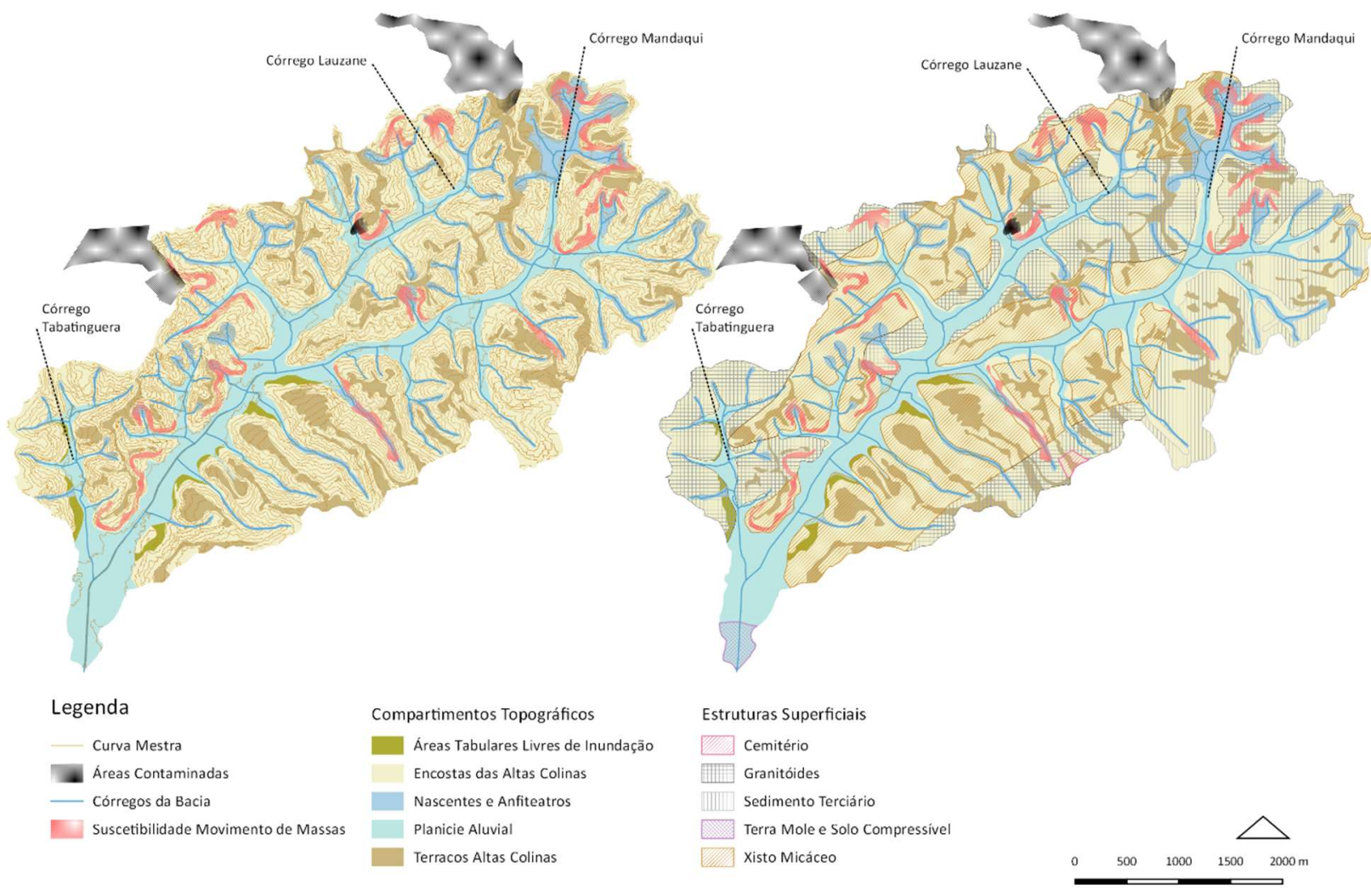

Fonte: elaborado pela autora.

\subsection{FISIOLOGIA DA PAISAGEM}

A fisiologia da paisagem tem o objetivo de compreender como as ocupações e usos do solo atuais impactam e são impactadas pelo relevo e pelos processos associados às estruturas superficiais descritas anteriormente. Para tanto, foi elaborada uma análise abordando a Bacia Hidrográfica em escala 1:5000, relacionando as principais tipologias de cobertura do solo urbano, a regulação hídrica e os LID. Foram delimitados os seguintes Compartimentos Estruturantes da Paisagem: Invernada da Polícia Militar; Nascentes e Anfiteatros; Topos das Altas Colinas; Encostas das Altas Colinas e; Fundo de Vale. Em seguida, as tipologias LID identificadas pelo Projeto Jaguaré (ver Parte I- Capítulo 5), foram relacionadas aos compartimentos com o intuito de identificar os potenciais de integração da IEVu em cada um deles. 
As taxas de permeabilidade da bacia são bastante variadas. A presença massiva de lotes de dimensões ao redor de $125 \mathrm{~m}^{2}$, são características presentes em algumas das áreas mais pavimentadas da bacia. Segundo os Planos Estratégicos Regionais de 2004, esses lotes poderiam ter até $85 \%$ de suas áreas impermeabilizadas, já os lotes maiores que $250 \mathrm{~m}^{2}$ teriam impermeabilização máxima entre 50 e 70\%, dependendo da zonificação a qual pertencem. Galpões industriais de médio e grande porte podem ocupar até $100 \%$ das áreas dos lotes ou terem pátios e áreas de manobra muito impermeabilizados. Em sua maioria, estas estruturas estão localizadas nas áreas de fundo de vale da bacia. Quanto aos núcleos de edifícios, é verificada a presença do verde nos jardins internos aos empreendimentos, no entanto, é muito difícil saber se estas áreas são permeáveis, se estão sobre laje, ou mesmo se possuem solos impermeabilizados abaixo das copas das árvores. Essa última configuração, arborizadoimpermeabilizado, ocorre por exemplo nas áreas do Hospital Mandaqui. O impacto que cada uma dessas tipologias tem para a regulação das águas acompanha a descrição da sequência de imagens apresentada a seguir.

As tipologias de lotes apresentadas nas Figuras 48 e 49, possuem áreas variando desde metragens inferiores a $125 \mathrm{~m}^{2}$ até cerca de $250 \mathrm{~m}^{2}$, com altas taxas de impermeabilização do solo e escassas áreas verdes públicas ou arborização viária. São encontradas em todos os compartimentos de relevo e impactam o escoamento superficial, devido ao aumento do volume e velocidade do escoamento, ao mesmo tempo que reduzem as possibilidades de infiltração. Essa configuração urbana também colabora para que as cargas poluentes difusas cheguem praticamente integrais aos cursos d'água a jusante.

Nas áreas ao norte da bacia são encontrados os núcleos de edificações mais expressivos da bacia. No exemplo da Figura 50, são mostrados os lotes de média a grandes dimensões com edifícios acima de 10 pavimentos e áreas verdes intrínsecas ao empreendimento, sem que seja possível identificar quais estão sobre solo permeável, laje ou ainda se possuem impermeabilização sob as copas das árvores. Essa tipologia é normalmente encontrada nos compartimentos de Nascentes e Anfiteatros, Topos das Altas Colinas e Encostas das Altas Colinas, sobre sedimentos terciários e granitoides. Quando possuem áreas permeáveis, poderão 
contribuir para a infiltração das águas nos dois primeiros compartimentos topográficos e estabilização de taludes ao longo das encostas.

Figura 48 e 49: Bairros homogêneos com lotes pequenos e muito impermeabilizados.
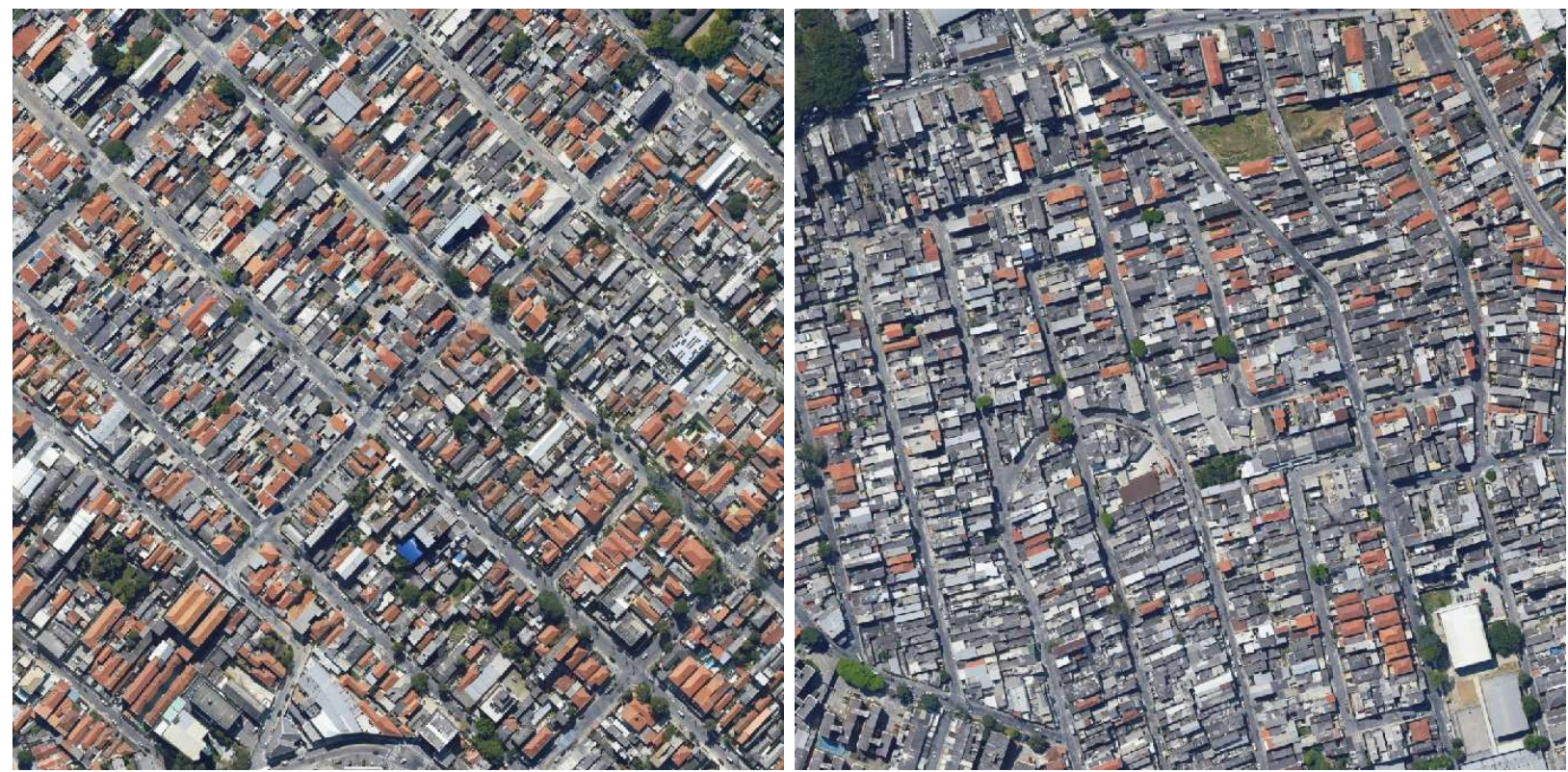

Fonte: ortofoto PMSP (2017).

Figura 50: Tipologia de edifícios com jardins.

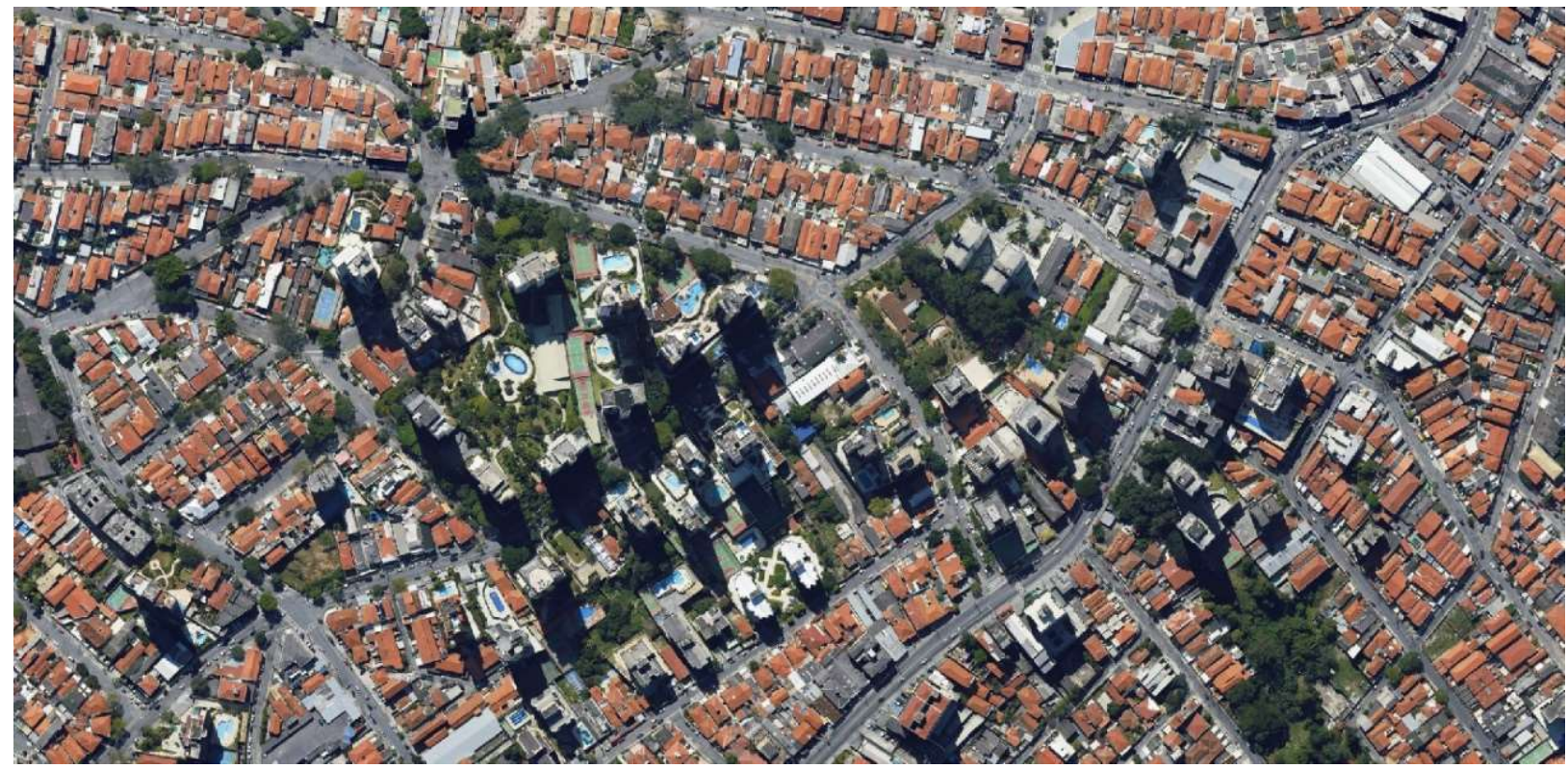

Fonte: ortofoto PMSP (2017). 
As tipologias apresentadas na Figura 51, estão assentadas sobre as áreas de Encosta das Altas Colinas, em solos granitoides, e na Planície Aluvial do Mandaqui. Representam áreas com maior ou menor presença de áreas verdes públicas e lotes maiores que $250 \mathrm{~m}^{2}$, à esquerda da imagem, ou variando a partir de $125 \mathrm{~m}^{2}$, à direita. Entre essas tipologias, é visível que os lotes maiores ás vezes contam com pequenos resquícios de jardim nas áreas de recuo frontal, enquanto os menores normalmente ocupam toda essa área para extensão de garagens ou de segundo piso (Figuras 52 e 53 respectivamente). No setor esquerdo, a localização das áreas verdes públicas ao longo das vias, em taludes bastante inclinados, forma um cordão de amortecimento das águas que descem das partes mais altas do relevo, preservando a integridade dos solos nessas áreas e fornecendo outros SE, principalmente relacionados ao microclima.

Figura 51: Distintos tipos de ocupação do solo da bacia, no seu trecho norte.

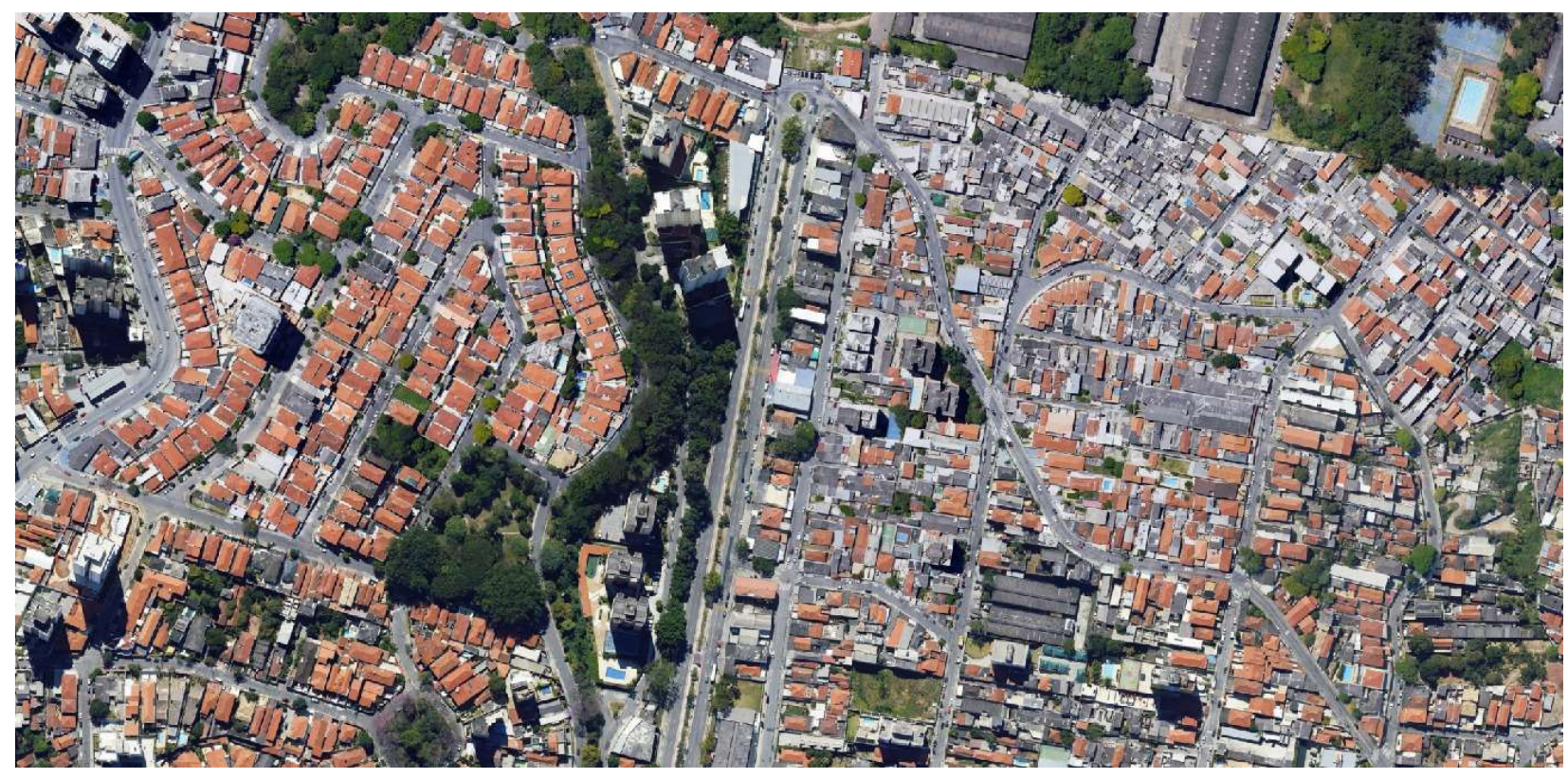

Fonte: ortofoto PMSP (2017).

Figura 52 e 53: diferenças entre os assentamentos à esquerda e à direita.
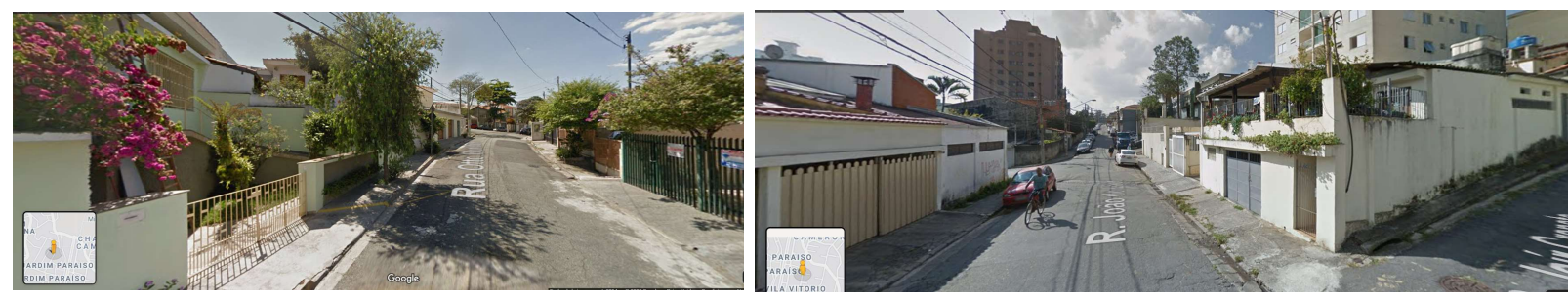

Fonte: google street view (2019). 
A área do Hospital do Mandaqui (Figura 54), apresenta densa vegetação arbórea que forma um grande dossel capaz de contribuir para o amortecimento do impacto das chuvas no solo, mas devido à impermeabilização dos pisos sob as árvores poderá haver um incremento do escoamento superficial nessas áreas.

Figura 54: Usos especiais. Exemplo do Hospital Mandaqui.

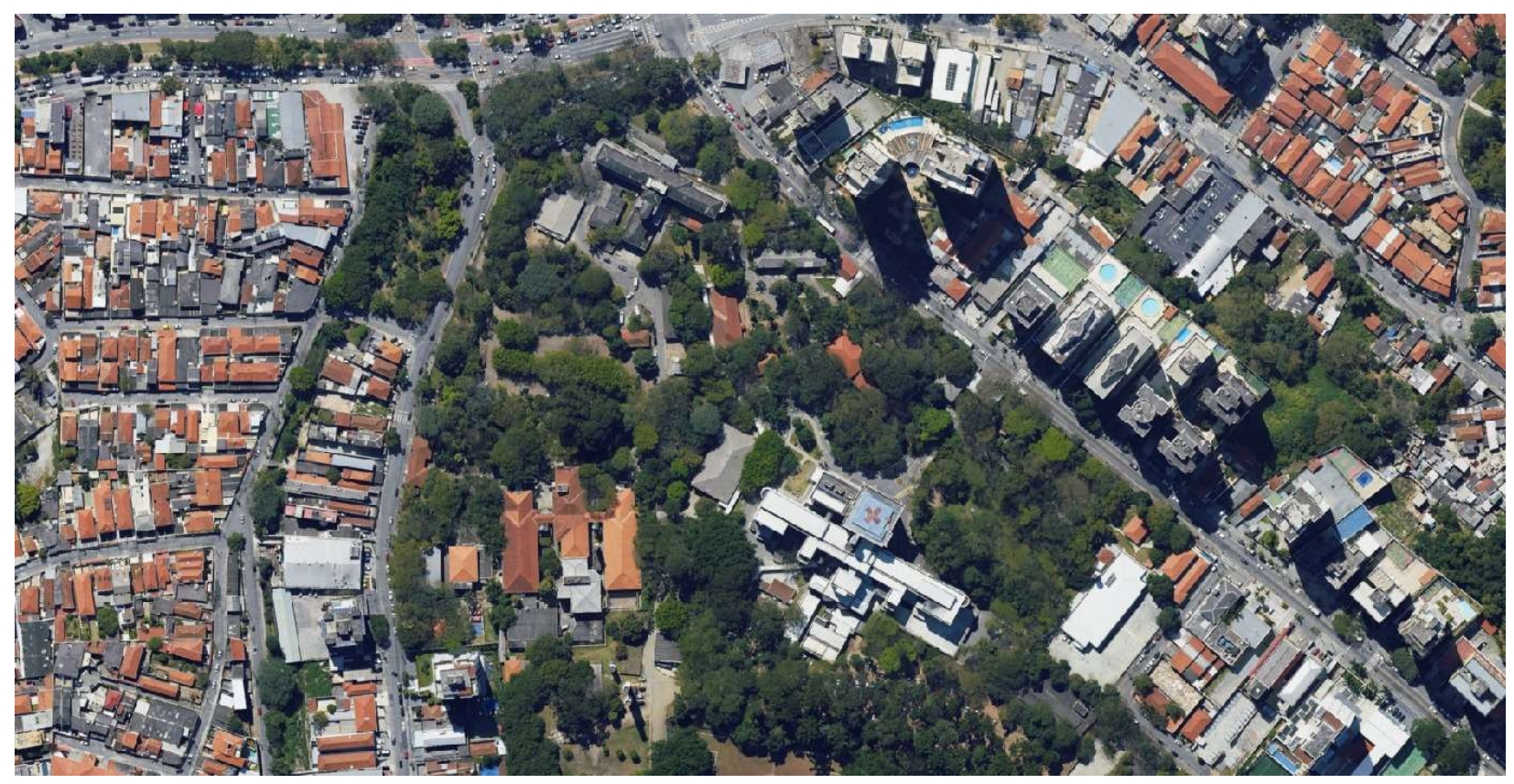

Fonte: ortofoto PMSP (2017).

A Invernada da Polícia Militar (Figura 55), abriga um dos conjuntos de nascentes e anfiteatros do Mandaqui. Seu estado bastante conservado e de vegetação estratificada remanescente da Mata Atlântica, contribui para a estabilidade das áreas íngremes dos anfiteatros e manutenção da integridade das nascentes. Também contribui para a redução da velocidade e volume do escoamento superficial, amortecendo o impacto das chuvas no solo, primeiro pela presença de dossel arbóreo e em seguida pela formação de serapilheira. Por suas características estratégicas, a Invernada foi definida como um Compartimento específico de paisagem. 
Figura 55: Áreas de Conservação- Invernada da Polícia Militar.

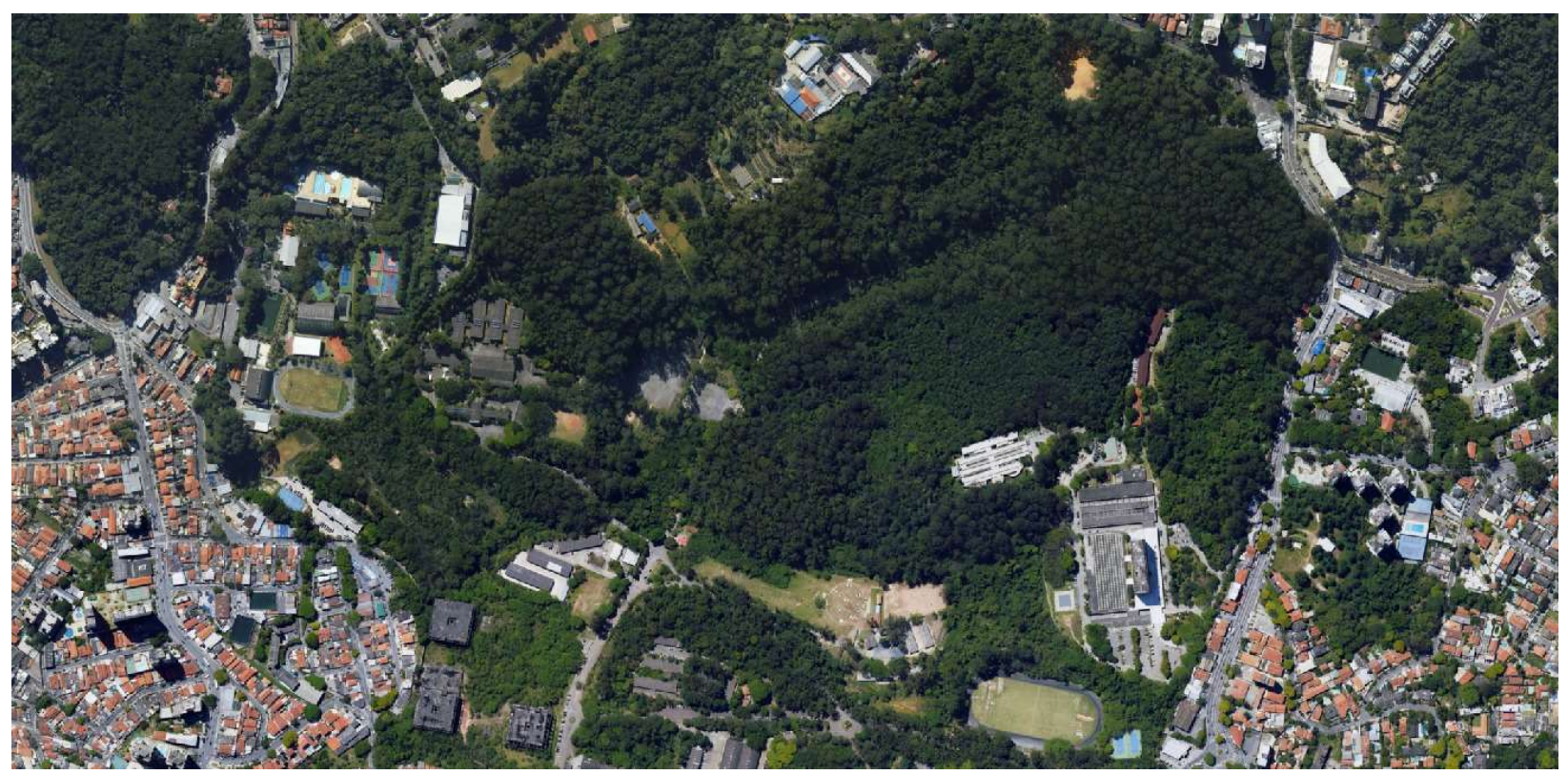

Fonte: ortofoto PMSP (2017).

Outra tipologia bastante presente, sobretudo ao longo das Planícies Aluviais do Mandaqui e Tietê, são os galpões Industriais e comerciais e os grandes equipamentos (Figuras 56 e 57). Nestas áreas a taxa de impermeabilização é bastante alta, podendo chegar a 100\%. A presença de vegetação é pontual e normalmente está sobre piso impermeável; há risco de contaminação do escoamento superficial por cargas difusas industriais. Por outro lado, alguns desses grandes terrenos, com espaços abertos amplos, tem potencial para serem convertidos em áreas de reservação das águas de chuva ao mesmo tempo que agregam outros usos do espaço.

$\mathrm{Na}$ bacia encontram-se também alguns assentamentos irregulares do tipo favela, havendo uma concentração maior às margens do córrego Tabatinguera e seus afluentes (Figura 58). O Programa Córrego Limpo atuou na área para a coleta e destinação dos esgotos, mas ao longo dos anos novas instalações irregulares passaram a lançar as águas residuais diretamente no córrego. A impermeabilização dos solos é muito alta devido a densidade construtiva, mas é possível encontrar algumas áreas verdes em trechos do Tabatinguera, que ajudam a manter a estabilidade dos taludes e contribuem, mesmo que nas atuais circunstância de forma ínfima, para a melhora da qualidade das águas. São áreas normalmente bastante afetadas em épocas de cheias, com 
potencial para serem adaptadas a fornecer múltiplos serviços ecossistêmicos, integrados ao processo de urbanização das favelas.

Figura 56 e 57: Tipologia de grandes galpões industriais e comerciais.
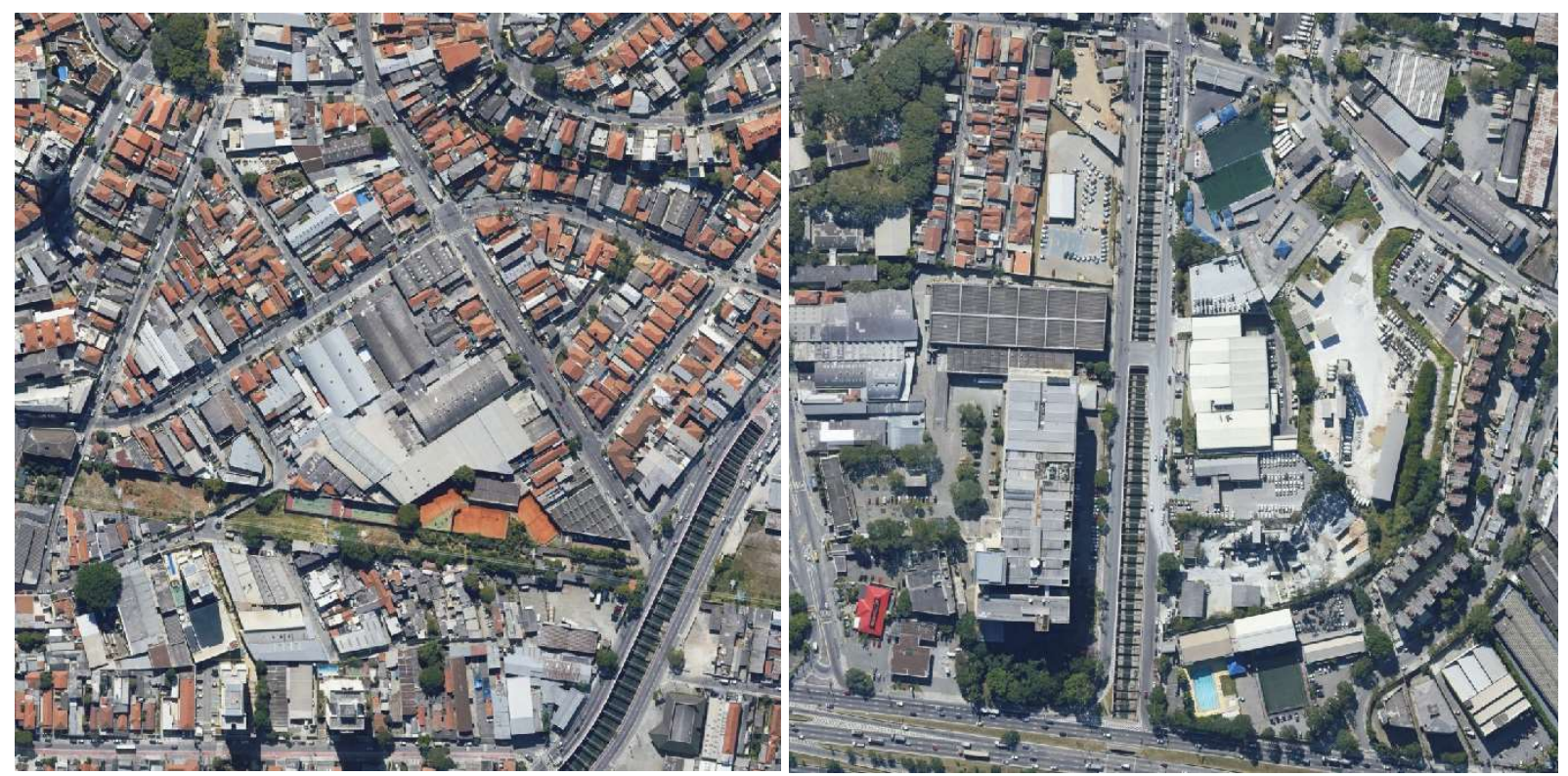

Fonte: ortofoto PMSP (2017).

Figura 58: Tipologia construções irregulares.

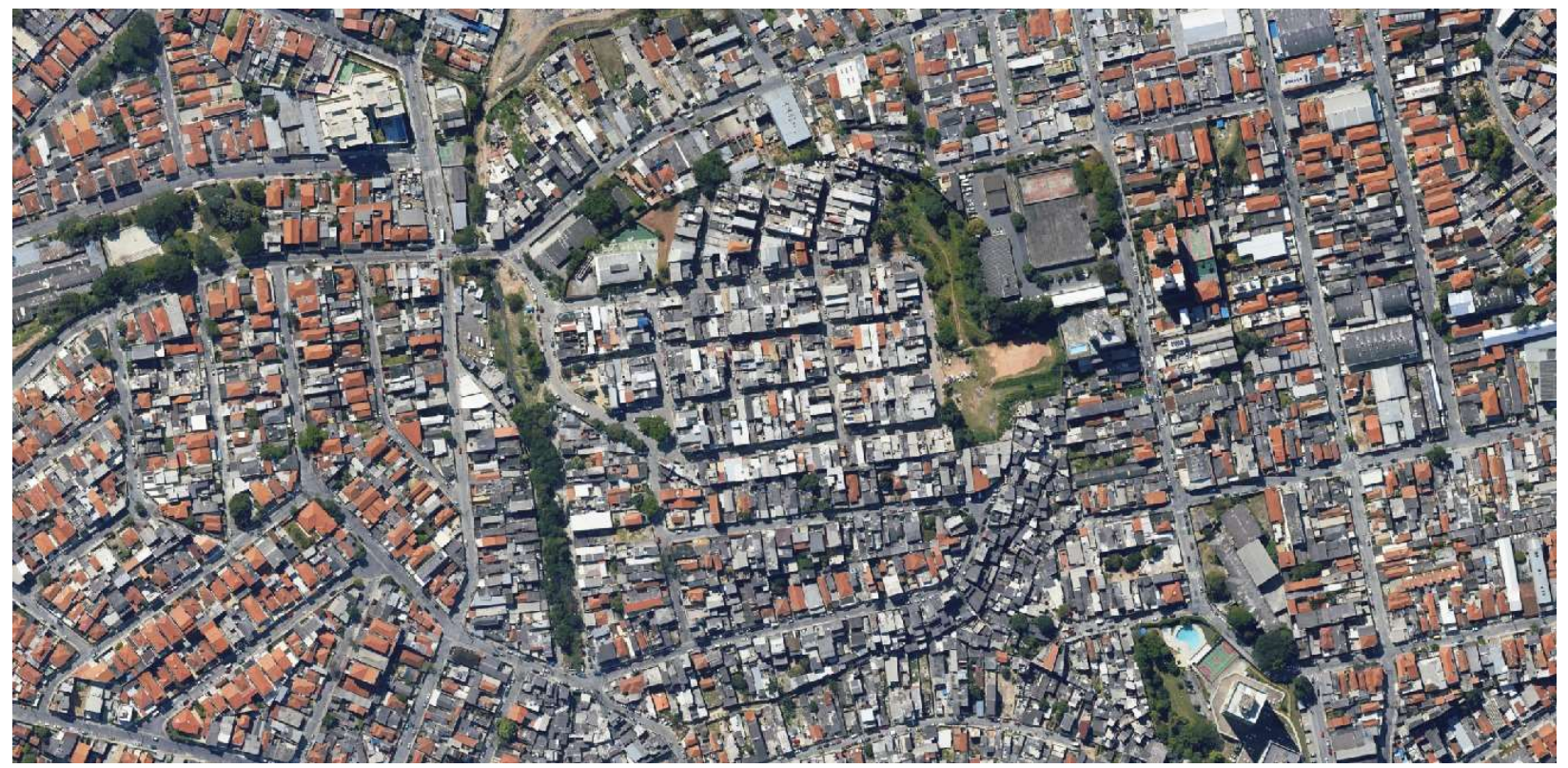

Fonte: ortofoto PMSP (2017). 
Como resultado da análise apresentada, foram definidos e geolocalizados cada um dos Compartimentos Estruturantes da Paisagem definidos: Invernada da Polícia Militar; Nascentes e Anfiteatros; Topos das Altas Colinas; Encostas das Altas Colinas; Áreas tabulares livres de inundação; e Fundo de Vale (Figura 59). Descritos em seguida.

Compartimento Estratégico Invernada da Polícia Militar

Compartimento Estratégico Estruturante da Paisagem por compreender área de conservação ambiental. Possui ocupação esparsa por edifícios pontuais e abriga remanescentes da Mata Atlântica. Seu relevo varia entre as cotas $751 \mathrm{~m}$ e $808 \mathrm{~m}$ e é conformado por distintos compartimentos topográficos: Planície Aluvial; Altas Colinas, Terraços das Altas Colinas e Nascentes e Anfiteatros (onde se encontram parte das cabeceiras das nascentes do Mandaqui). Área com suscetibilidade a movimento de massas, (erosões), devido às grandes inclinações de encostas e anfiteatros e às formações de xistos- micáceos e granitoides. Apesar do predomínio do escoamento superficial e dos riscos de erosões, tais ações são amortecidas pelas densas e estratificadas áreas verdes deste compartimento.

\section{Nascentes e Anfiteatros}

Áreas de vales encaixados no relevo e anfiteatros das nascentes do Mandaqui e de seus afluentes com inclinações variando até $10 \%$ e anfiteatros tendendo a inclinações superiores a $60 \%$. São suscetíveis a movimentos de massas devido às grandes inclinações das encostas e dos anfiteatros em áreas conformadas por xistos- micáceos e granitoides. Devido às altas inclinações, favorece o processo de desgaste do solo e escoamento das águas superficiais. A infiltração não é beneficiada nestas áreas, sobretudo naquelas com formações terciárias (argilas espessas). São encontradas três situações urbanas: 1. Áreas verdes; 2. Área de ocupação irregular (favelas); 3. Área de ocupação regular consolidada. As áreas verdes favorecem a conservação das nascentes e mitigam a ocorrência de erosões. As outras tipologias urbanas favorecem o escoamento 
superficial e podem ser afetadas pelos processos erosivos ou potencializarem a ocorrência deles, (por estarem assentadas em áreas de declividades superiores a $20 \%$ ou $30 \%$ ). ${ }^{62}$

Topos das Altas Colinas

Áreas localizadas na parte superior das colinas, possuem alturas que variam entre 740 e 803m e inclinação entre 0-10\%. Essas áreas, compostas por granitoides, com textura argiloarenosa possuem maior potencial para a infiltração das águas de chuva, favorecido pela localização do lençol freático a cerca de $8 \mathrm{~m}$ abaixo da superfície, o que garante boa percolação da água infiltrada (SCHUTZER, 2012). Já as áreas compostas por xistos- micáceos favorecem o escoamento superficial e a ocorrência de processos erosivos, escorregamento de taludes e aterros; as áreas compostas por sedimentos terciários também possuem como característica sua predominância argilosa e espessa, que favorecem o escoamento em relação aos demais processos hidrológicos. Muitos desses compartimentos da paisagem estão ocupados por vias que fazem a conexão através dessas porções mais planas do relevo através dos topos das colinas vizinhas ou conectam a planície aluvial do Mandaqui com as áreas a leste e norte. Tais vias, com áreas bastante impermeabilizadas, não potencializam o processo natural de infiltração dessas áreas, ao invés disso, cumprem uma função de distribuir o escoamento superficial para as áreas mais íngremes da bacia o que pode reforçar a ocorrência de processos erosivos característicos de alguns setores desse compartimento, além do impacto a jusante.

\section{Encostas das Altas Colinas}

As encostas estão dispostas ao longo de toda a bacia e representam o maior compartimento da paisagem. São caracterizadas por vertentes abruptas que podem variar desde cotas próximas às da Planície Aluvial (730 m), àquelas conectadas à Serra da Cantareira (808 m). Suas áreas tem inclinação predominante entre $20 \%$ e $30 \%$, característica que favorece o escoamento rápido das águas de chuva e a suscetibilidade quanto aos movimentos de massa e erosão (IPT, 2015). As topologias urbanas e usos do solo são diversas nesse setor e contribuem

\footnotetext{
${ }^{62}$ Art. 3으 Lei no 6.766 de 1979, sobre o parcelamento do solo urbano, proíbe a construção em terrenos com declividade igual ou superior a $30 \%$ devido ao alto risco de processos erosivos e deslizamentos de solo.
} 
para o aumento do escoamento superficial. As exceções são compostas por áreas verdes localizadas no tramo superior da bacia, limítrofes às Planícies Aluviais, e que colaboram para a contenção de taludes na margem direta do Mandaqui, amortecendo em parte o escoamento superficial proveniente das partes mais altas da bacia.

Áreas tabulares livres de inundação

São áreas bastante limitadas na bacia, com alturas variando entre $725 \mathrm{~m}$ a $730 \mathrm{~m} \mathrm{e}$ inclinações entre 0-10\%. Apesar de bastante planas estão localizadas fora da Planície Aluvial, protegidas das inundações. São áreas receptoras dos impactos gerados nas Encostas das Altas Colinas e sua função principal seria amortecer o impacto das águas e conduzi-las até o fundo de vale. Porém, por possuir ocupação variável e escassez de áreas verdes, normalmente não são capazes de cumprir com o papel de amortecimento das águas provenientes das áreas mais altas da bacia.

Planície Aluvial- o Fundo de Vale

Delimitada pelas Encostas das Altas Colinas e influenciada pela Planície aluvial do rio Tietê, esse compartimento da paisagem conta com baixas declividades, entre 0-5\%, podendo chegar até $10 \%$ em pontos específicos, e com elevações variando entre $726 \mathrm{~m}$ a $750 \mathrm{~m}$. Possui solos arenosos e argilosos, com lençol freático superficial e áreas propensas a recalques que podem danificar pavimentos, redes de infraestruturas e edificações, além de estarem sujeitas a inundação. É uma área onde o armazenamento das águas predomina à infiltração (devido ao lençol freático alto variando entre 0,5 e 3,00m de profundidade, SCHUTZER, 2019), e à dificuldade de manter o escoamento superficial (devido às baixas declividades). Representa o compartimento da paisagem ocupado pelo córrego Mandaqui e seus afluentes, assim como pelas avenidas que os acompanham, em especial a av. Engenheiro Caetano Álvares e a av. Direitos Humanos. A ocupação do solo é variada, concentrando mais usos industriais leves e comerciais bastante impermeabilizados até o trecho médio da avenida Engenheiro Caetano Álvares, com pouco ou nenhum recuo frontal e pouco espaço de armazenamento das águas de chuva. Em fundos de vale urbanizados, o conjunto canal-vias adjacentes corresponde, historicamente, à área de 
intervenção prioritária para a contenção de enchentes. A delimitação da Planície Aluvial e a compreensão da sua relação com os demais Compartimentos da Paisagem, amplia esse horizonte de ação e nos fornece os subsídios necessários para considerar os processos de drenagem de forma mais abrangente e com maiores possibilidades de flexibilização durante eventos chuvosos. O buffer de 300m inicialmente delimitado no fundo de vale, seguindo a indicação de influência do corredor de ônibus urbano, foi mantido como referência entre o que estipula o plano urbano e os limites dos processos de paisagem.

Figura 59: Mapa de Compartimentação da Paisagem.

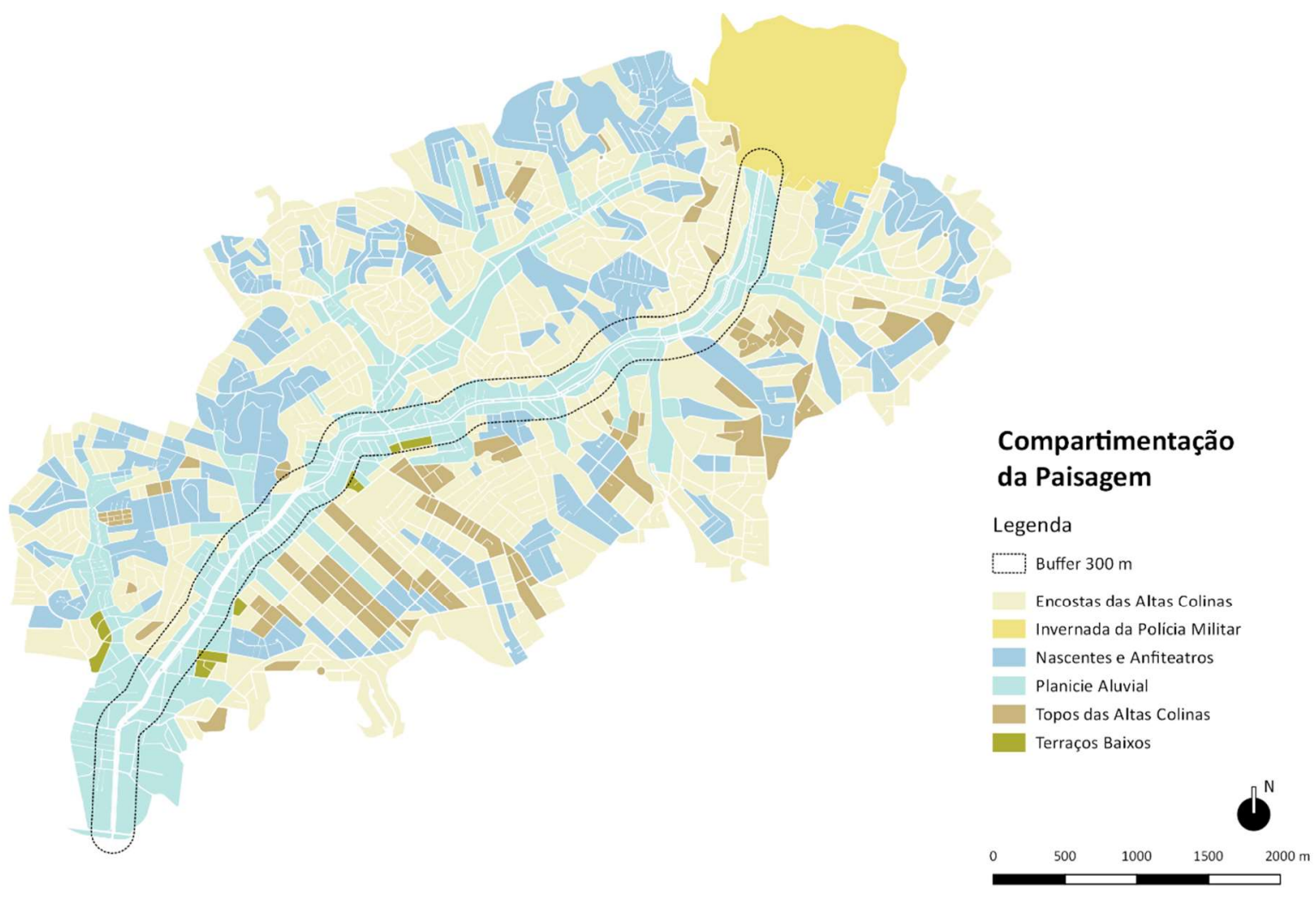

Fonte: elaborado pela autora.

\subsection{DISTRIBUIÇÃO DE LIDS E ARBORIZAÇÃO URBANA NOS COMPARTIMENTOS DA} PAISAGEM

Cada tipologia LID (ver Parte I- Capítulo 5) apresenta uma interação com os processos de drenagem e se adapta melhor a algumas tipologias urbanas (Quadro 11). De modo geral, os lotes 
construídos deverão se apoiar em estratégias para a desconexão das calhas, direcionando as águas dos telhados para reservatórios de passagem, os quais podem estar associados a cisternas para o aproveitamento das águas das chuvas, ou a jardins de chuva, para promover a infiltração lenta das águas. Indica-se para os lotes de tamanho reduzido, a utilização de cisternas de pequenas dimensões, não enterradas e que possam ser instaladas em áreas externas reduzidas. A instalação de jardins de chuva, quando exista área de jardim, será mais indicada para as áreas de Topos das Altas Colinas, favorecendo a infiltração. Os edifícios, principalmente aqueles com lajes planas poderão explorar as possibilidades de instalação de tetos verdes com reservatórios associados ou cisternas localizadas em outras áreas do empreendimento.

Em relação aos córregos que recebem esgotos domésticos, uma opção às canalizações externas do Programa Córrego Limpo podem ser os Filtros Biológicos e, se há maior espaço disponível, wetlands. Essas estratégias poderão contribuir com outros serviços ecossistêmicos, principalmente culturais quando integrados a novos espaços públicos propostos como por exemplo, em áreas de urbanização de favelas. Uma vez incorporados a praças ou parques, o sistema poderá ser desenhado para reuso das águas tratadas para irrigação de jardins, hortas etc. desde que atendidas as normas de qualidade de água para essas distintas finalidades.

Quanto à detenção das águas, tecnologias in-line e off-line de menores escalas podem ser espraiadas por toda a bacia, reduzindo o impacto dos volumes de chuva na Planície Aluvial. Devido ao predomínio de áreas bastante inclinadas, estas estratégias poderão estar sobretudo incorporadas ao longo dos córregos abertos, e em áreas de Topo das Altas Colinas. Nas encostas, a formação de colchões verdes arbóreos, com canaletas pluviais incorporadas aos taludes, poderá minimizar o impacto das águas nas áreas mais baixas da bacia e evitar o movimento de massas.

O Projeto Jaguaré não considerou a Floresta Urbana como fator de contribuição para a regulação hídrica, no entanto, em áreas urbanas densamente impermeabilizadas e com escassez de Espaços Abertos, como o Mandaqui, o plantio e manejo da Floresta Urbana será de grande valia. As árvores podem mitigar vários impactos ambientais relacionados ao clima, qualidade do ar, redução de escoamento superficial e enchentes (NOWAK; DWYER, 2007). Diferentes espécies contribuirão mais ou menos para esse Serviço Ecossistêmico e poderão incorrer em desserviços. Por exemplo, estudos apontam que as espécies arbóreas Sibipiruna (Caesalpinia pluviosa) e 
Tipuana (Tipuana tipu) são capazes de interceptar até $60 \%$ da água de chuva que incide sobre suas copas (SILVA et al. 2009 apud LOCATELLI et al., 2017) ${ }^{63}$. Por outro lado, estas espécies poderão resultar em desserviços ecossistêmicos por conta de seu grande porte, afetando outras infraestruturas urbanas, aéreas e subterrâneas, além de poder danificar pisos e pavimentos.

Em estudo elaborado por Locatelli et al. (2017) no âmbito do Projeto Resiliência Urbana, é possível observar que as áreas de Encostas e Topos das Altas Colinas do Mandaqui, por sua declividade e escassez de cobertura vegetal, são caracterizadas com prioridade variando entre média-alta a muito alta quanto à necessidade de plantio arbóreo com a finalidade de reduzir o escoamento superficial. Já as áreas de fundo de vale pouco vegetadas, por exemplo o trecho inferior do Mandaqui e a avenida Direitos Humanos, são indicadas com prioridade média (ibid). Nesses trechos de Planície Aluvial a arborização não terá papel crucial para a drenagem, no entanto, poderá fornecer outros SE relacionados diretamente aos benefícios de bem-estar e saúde.

O manejo da Floresta Urbana poderá contribuir para o fornecimento de Serviços Ecossistêmicos diferentes em cada um dos compartimentos da paisagem. Nas áreas de Topos das Altas Colinas, irão beneficiar a infiltração das águas de chuva. Ao longo das Encostas, serão de grande valia para a estabilização das íngremes vertentes, podendo também contribuir para a infiltração das águas nos solos com maior permeabilidade. Em ambos casos tanto as copas interceptarão as primeiras chuvas quanto as áreas de solo associadas às árvores poderão colaborar para a redução do escoamento superficial. Já nas Áreas tabulares livres de inundação e nas Planícies Aluviais, a arborização terá maior contribuição para melhora do microclima, beneficiando os modos de mobilidade ativa e os usos de recreação e esporte ao longo do vale. De modo geral, esses benefícios poderão ocorrer em todos os compartimentos da paisagem, relacionados aos demais Serviços Ecossistêmicos prestados, a fim de garantir a multifuncionalidade do sistema.

\footnotetext{
${ }^{63}$ SILVA, L.F. et al. Capacidade de interceptação pelas árvores e suas influências no escoamento superficial urbano. REVSBAU, Piracicaba - SP, v.4, n.3, p.32-48, 2009.
} 
Quadro 11: LID e floresta urbana associados aos Compartimento da Paisagem.

\begin{tabular}{|c|c|}
\hline $\begin{array}{l}\text { Compartimento Ambientais } \\
\text { Estruturantes da Paisagem }\end{array}$ & Ação/ LID sugerido \\
\hline $\begin{array}{l}\text { Compartimento Estratégico } \\
\text { Invernada da Polícia Militar }\end{array}$ & $\begin{array}{l}\text { Manutenção das áreas verdes existentes; Instalação de biovaletas e } \\
\text { jardins de chuva escalonados nas áreas edificadas e ao longo das } \\
\text { ruas internas. Objetivo: infiltrar a água de chuva e amortecer os } \\
\text { volumes carreados a jusante. }\end{array}$ \\
\hline Nascentes e Anfiteatros & $\begin{array}{l}\text { 1) áreas verdes: manter a integridade do ecossistema. Objetivo: } \\
\text { conservar anfiteatros e nascentes evitando a ocorrência de erosões. } \\
\text { 2) áreas de favelas: incorporar no desenho de urbanização a } \\
\text { conservação das nascentes, além de canteiros pluviais, biovaletas } \\
\text { escalonados. No córrego, instalar reservatórios in-line. Objetivo: } \\
\text { conservar as nascentes, amortecer o impacto das chuvas e evitar } \\
\text { erosões. 3) áreas consolidadas: calha desconectada em jardim de } \\
\text { chuva ou reservatório. Objetivo: amortecer o impacto do } \\
\text { escoamento superficial e infiltrar água quando possível. } \\
\text { A Floreta Urbana seguirá os objetivos destacados. }\end{array}$ \\
\hline Topos das Altas Colinas & $\begin{array}{l}\text { Jardim de chuva; Canteiro Pluvial; Biovaletas; reservatórios off-line. } \\
\text { Objetivo: Infiltração, detenção e distribuição dos volumes de chuva. } \\
\text { Floresta urbana atuará na infiltração e amortecimento do } \\
\text { escoamento superficial. }\end{array}$ \\
\hline Encostas das Altas Colinas & $\begin{array}{l}\text { Biovaleta e Canteiro Pluvial escalonados até declividades máximas } \\
\text { de } 30 \% \text {. Acima desta declividade recomenda-se o plantio de } \\
\text { vegetação arbustiva e arbórea ao longo dos taludes e sua } \\
\text { estabilização com gabiões e geomanta, quando necessário. Áreas de } \\
\text { reservação in-line, ao longo dos cursos d'água. Objetivo: amortecer } \\
\text { o impacto as águas a jusante e evitar erosões. }\end{array}$ \\
\hline $\begin{array}{c}\text { Áreas tabulares livres de } \\
\text { inundação }\end{array}$ & $\begin{array}{l}\text { Biovaleta, Canteiro Pluvial, Jardim de chuva e reservatórios in line e } \\
\text { off line. Pavimentos permeáveis (inclinação até 5\%) Objetivo: } \\
\text { amortecer o impacto das águas a jusante. }\end{array}$ \\
\hline Planícies Aluviais & $\begin{array}{l}\text { Reservatórios In line e off line; Pavimento permeável com } \\
\text { reservatório e biovaleta em áreas com lençol freático abaixo de } 60 \\
\mathrm{~cm} \text {. }\end{array}$ \\
\hline
\end{tabular}

Fonte: elaborado pela autora.

Embora os LID tenham seus objetivos principais focados na drenagem, é interessante observar as possibilidades que cada tipologia possui para o fornecimento de outros Serviços Ecossistêmicos e suporte às Funções Urbanas. Esse potencial poderá ser relacionado à aptidão 
dos Espaços Abertos para favorecer as sinergias na rede de IEV. O Quadro 12 sintetiza as relações potenciais entre as distintas tipologias LID e a Floresta Urbana aos SE.

Quadro 12: Aptidão dos LID e Floresta Urbana em fornecer Serviços Ecossistêmicos e Funções Urbanas.

\begin{tabular}{|c|c|c|c|c|c|c|c|c|c|c|c|c|}
\hline & $\frac{\frac{\pi}{0}}{\frac{\pi}{\pi}}$ & $\begin{array}{l}\frac{\pi}{2} \\
\frac{J}{0} \\
0 \\
\frac{\pi}{0} \\
\frac{0}{\pi} \\
\frac{0}{0} \\
\tilde{U}\end{array}$ & 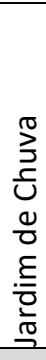 & $\begin{array}{l}\frac{0}{0} \\
\frac{1}{2} \\
\stackrel{0}{0} \\
\stackrel{+}{0} \\
\end{array}$ & 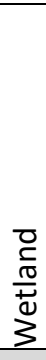 & 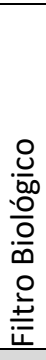 & 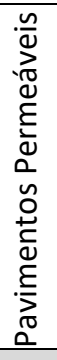 & 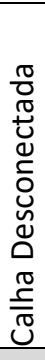 & 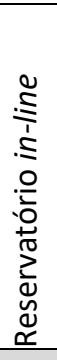 & 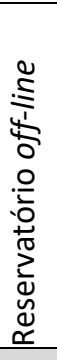 & 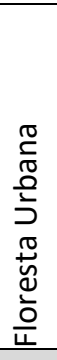 & \\
\hline Habitat & & & & & & & & & & & & Referências \\
\hline Biodiversidade & $\mathrm{x}$ & $\mathrm{x}$ & $x$ & $x$ & 0 & 0 & 0 & 0 & $x$ & $\mathrm{x}$ & $x$ & UACDC, 2010 \\
\hline Cursos d’água bióticos & 0 & 0 & 0 & 0 & 0 & 0 & 0 & 0 & 0 & 0 & 0 & - \\
\hline Eficiência metabólica & 0 & 0 & 0 & 0 & $x$ & $x$ & 0 & 0 & 0 & 0 & 0 & FCTH, 2017 \\
\hline Captação de Radiação & 0 & 0 & 0 & 0 & 0 & 0 & 0 & 0 & 0 & 0 & 0 & - \\
\hline $\begin{array}{l}\text { Redução de perdas de } \\
\text { nutrientes }\end{array}$ & 0 & 0 & 0 & 0 & 0 & 0 & 0 & 0 & 0 & 0 & 0 & - \\
\hline \multicolumn{13}{|l|}{ Serviços de Provisão } \\
\hline Agricultura urbana & 0 & 0 & 0 & $x$ & 0 & 0 & 0 & 0 & 0 & 0 & 0 & $\begin{array}{l}\text { Possibilidade de uso } \\
\text { dos tetos verdes. }\end{array}$ \\
\hline Energia & 0 & 0 & 0 & $\mathrm{x}$ & 0 & 0 & 0 & 0 & 0 & 0 & $x$ & $\begin{array}{l}\text { CANTUZZO; } \\
\text { LOMBARDO, } 2005 . \\
\text { Tetos verdes podem } \\
\text { reduzir o consumo de } \\
\text { energia em edifícios. }\end{array}$ \\
\hline Água fresca & 0 & 0 & 0 & 0 & 0 & 0 & 0 & 0 & 0 & 0 & 0 & - \\
\hline \multicolumn{13}{|l|}{ Serviços de Regulação } \\
\hline Proteção a enchentes & 0 & $x$ & $x$ & $x$ & 0 & 0 & $x$ & $x$ & $x$ & $x$ & 0 & FCTH, 2017 \\
\hline $\begin{array}{l}\text { Amortização de } \\
\text { escoamento } \\
\text { superficial }\end{array}$ & $x$ & $x$ & $x$ & $x$ & 0 & 0 & $x$ & $x$ & $x$ & $x$ & $x$ & $\begin{array}{l}\text { FCTH, 2017; NOWAK; } \\
\text { DWYER, } 2007\end{array}$ \\
\hline Recarga de aquíferos & $\mathrm{x}$ & $x$ & $x$ & 0 & 0 & 0 & 0 & 0 & 0 & $x$ & $x$ & \multirow{5}{*}{ NOWAK; DWYER, 2007} \\
\hline $\begin{array}{l}\text { Regulação da } \\
\text { Qualidade do ar }\end{array}$ & 0 & 0 & 0 & 0 & 0 & 0 & 0 & 0 & 0 & 0 & $x$ & \\
\hline Mitigação de ruído & 0 & 0 & 0 & 0 & 0 & 0 & 0 & 0 & 0 & 0 & $x$ & \\
\hline Controle da erosão & 0 & $x$ & 0 & 0 & 0 & 0 & 0 & 0 & $x$ & 0 & $x$ & \\
\hline $\begin{array}{l}\text { Regulação de } \\
\text { nutrientes }\end{array}$ & $x$ & $\mathrm{x}$ & $x$ & 0 & $x$ & $x$ & 0 & 0 & $x$ & $x$ & 0 & \\
\hline $\begin{array}{l}\text { Descontaminação das } \\
\text { águas }\end{array}$ & $x$ & $x$ & $x$ & $\mathrm{x}$ & $x$ & $x$ & $x$ & 0 & $x$ & $x$ & $x$ & FCTH, 2017 \\
\hline $\begin{array}{l}\text { Polinização e } \\
\text { dispersão de } \\
\text { sementes }\end{array}$ & 0 & 0 & 0 & 0 & 0 & 0 & 0 & 0 & 0 & 0 & $x$ & NOWAK; DWYER, 2007 \\
\hline
\end{tabular}

Continua 


\begin{tabular}{|c|c|c|c|c|c|c|c|c|c|c|c|c|}
\hline $\begin{array}{l}\text { Regulação do } \\
\text { microclima }\end{array}$ & $\mathrm{x}$ & $\mathrm{x}$ & $\mathrm{x}$ & $x$ & $\mathrm{x}$ & $x$ & $\mathrm{x}$ & $\mathrm{x}$ & $\mathrm{x}$ & $x$ & $\mathrm{x}$ & $\begin{array}{l}\text { DUARTE et al., 2015. A } \\
\text { vegetação urbana e } \\
\text { pavimentos frios são } \\
\text { estratégias para mitigar } \\
\text { as ilhas de calor } \\
\text { urbanas. }\end{array}$ \\
\hline \multicolumn{13}{|l|}{ Serviços Culturais } \\
\hline $\begin{array}{l}\text { Recreação e } \\
\text { desenvolvimento } \\
\text { cognitivo }\end{array}$ & 0 & 0 & 0 & $x$ & 0 & 0 & 0 & 0 & $x$ & $x$ & $\mathrm{x}$ & $\begin{array}{l}\text { Associada aos } \\
\text { benefícios gerados pela } \\
\text { regulação } \\
\text { microclimática da } \\
\text { Floresta Urbana e à } \\
\text { instalação de Parques } \\
\text { Lineares e de regulação } \\
\text { das águas. Possibilidade } \\
\text { de uso dos tetos } \\
\text { verdes. }\end{array}$ \\
\hline Valores estéticos & $\mathrm{x}$ & $\mathrm{x}$ & $\mathrm{x}$ & $\mathrm{x}$ & $\mathrm{x}$ & $\mathrm{x}$ & $\mathrm{x}$ & $x$ & $\mathrm{x}$ & $x$ & $\mathrm{x}$ & $\begin{array}{l}\text { Incorporados ao } \\
\text { desenho de espaços } \\
\text { públicos e privados. }\end{array}$ \\
\hline Educação ambiental & $x$ & $\mathrm{x}$ & $\mathrm{x}$ & 0 & $\mathrm{x}$ & $\mathrm{x}$ & 0 & 0 & $\mathrm{x}$ & $x$ & 0 & $\begin{array}{l}\mathrm{KOH}, 2011 \text {. Associados } \\
\text { à revelação dos } \\
\text { processos ecológicos } \\
\text { como forma de } \\
\text { educação. }\end{array}$ \\
\hline \multicolumn{13}{|l|}{$\begin{array}{l}\text { Funções de } \\
\text { Mobilidade }\end{array}$} \\
\hline Mob. ativa-caminhada & 0 & 0 & 0 & 0 & 0 & 0 & $\mathrm{x}$ & 0 & $\mathrm{x}$ & $\mathrm{x}$ & $x$ & \multirow{2}{*}{$\begin{array}{l}\text { Associada aos } \\
\text { benefícios gerados pela } \\
\text { regulação } \\
\text { microclimática da } \\
\text { Floresta Urbana e à } \\
\text { instalação de Parques } \\
\text { Lineares e de regulação } \\
\text { das águas. }\end{array}$} \\
\hline Mob. ativa-bicicleta & 0 & 0 & 0 & 0 & 0 & 0 & $\mathrm{x}$ & 0 & $\mathrm{x}$ & $x$ & $\mathrm{x}$ & \\
\hline Transporte público & 0 & 0 & 0 & 0 & 0 & 0 & 0 & 0 & 0 & 0 & 0 & - \\
\hline Transporte privado & 0 & 0 & 0 & 0 & 0 & 0 & $\mathrm{x}$ & 0 & 0 & 0 & 0 & $\begin{array}{c}\text { Aplicação em } \\
\text { estacionamentos }\end{array}$ \\
\hline
\end{tabular}

Fonte: elaborado pela autora a partir de revisão bibliográfica. 


\section{INVENTÁRIO DOS ESPAÇOS ABERTOS E OS SERVIÇOS ECOSSISTEMICOS}

Os Espaços Abertos diferem em seus aspectos físicos e estruturais resultando no fornecimento de distintos Serviços Ecossistêmicos. A metodologia proposta pela tese, faz inicialmente um inventário desses espaços na escala da bacia do Mandaqui (1:5000), adaptando o procedimento desenvolvido no Projeto Jaguaré (FCTH, 2017). Verificou-se a pouca relevância das tipologias: verde associado ao comércio e serviço, verde associado ao industrial e verde associado ao residencial. Dessa forma, essas três tipologias foram agrupadas em "Áreas Descontínuas". Uma vez identificados, os Espaços Abertos são relacionados aos Compartimentos da Paisagem e dessa forma, aos distintos LID indicados para cada setor da paisagem.

Primeiramente foi identificada, em SIG, a gama de tipologias de Espaços Abertos: Praças; Áreas Verdes associadas ao viário; Áreas verdes associada a cursos d'água; Viário; Terrenos Baldios; Áreas Descontínuas (onde não é possível identificar a predominância de Espaços Abertos ou não); Linhão; Áreas Verdes Protegidas (ZEPAM e Áreas Remanescentes do Bioma Mata Atlântica) e Grandes Estacionamentos (Figura 60). Em seguida, estes espaços foram relacionados aos Compartimentos da Paisagem (Figura 61). O "Viário" corresponde à distância de lote a lote, ou seja, inclui as calçadas, leitos carroçáveis e canteiros centrais. Quando esses canteiros centrais são verdes, foram separados e classificados como "Área verde associada ao viário", quando são impermeáveis, permaneceram inseridos na classificação "Viário".

Os Espaços Abertos formados pelas Áreas Verdes Protegidas representam as maiores áreas verdes da bacia e equivalem a cerca de $20 \%$ do total, enquanto a soma dos outros espaços verdes (Associado ao viário e aos córregos abertos; terreno baldio; praças; e remanescentes da Mata Atlântica fora das ZEPAM) é de aproximadamente 5,9\%. Já o sistema viário ressalta como o Espaço Aberto mais representativo da bacia depois das Áreas Verdes Protegidas, representando quase $60 \%$ do total. Outros quase $12 \%$ são ocupados por tipologia Descontínuo e os estacionamentos e cemitério somam cerca de $1,2 \%$.

O sistema viário terá papel fundamental para a instalação da IEVu, mas terá que assumir novos objetivos ademais daqueles de mobilidade. Além disso, para aumentar o impacto e efetividade das estratégias de Infraestrutura Verde Urbana na bacia do Mandaqui, a mudança do uso de solo deverá ser considerada. Essa discussão está além do escopo da tese, mas estudos 
foram elaborados dentro do âmbito do Projeto Resiliência Urbana, considerando por exemplo alterações na forma urbana dos fundos de vale, pensados a partir das quadras e não dos lotes para atingir um melhor equilíbrio entre as áreas construídas e verdes intrínsecas ao tecido urbano e plenamente acessíveis às pessoas (FRANCO, 2019). Quanto à acessibilidade às Áreas Verdes Protegidas, vimos o dinamismo das leis com impacto no ordenamento da ocupação e uso do solo urbano e os entraves entre posicionamentos extremamente preservacionistas ou extremamente liberais que ainda pecam em lidar com as questões ambientais urbanas (ver Parte II- Subcapítulo 2.1).

Figura 60: Espaços Abertos identificados na bacia.

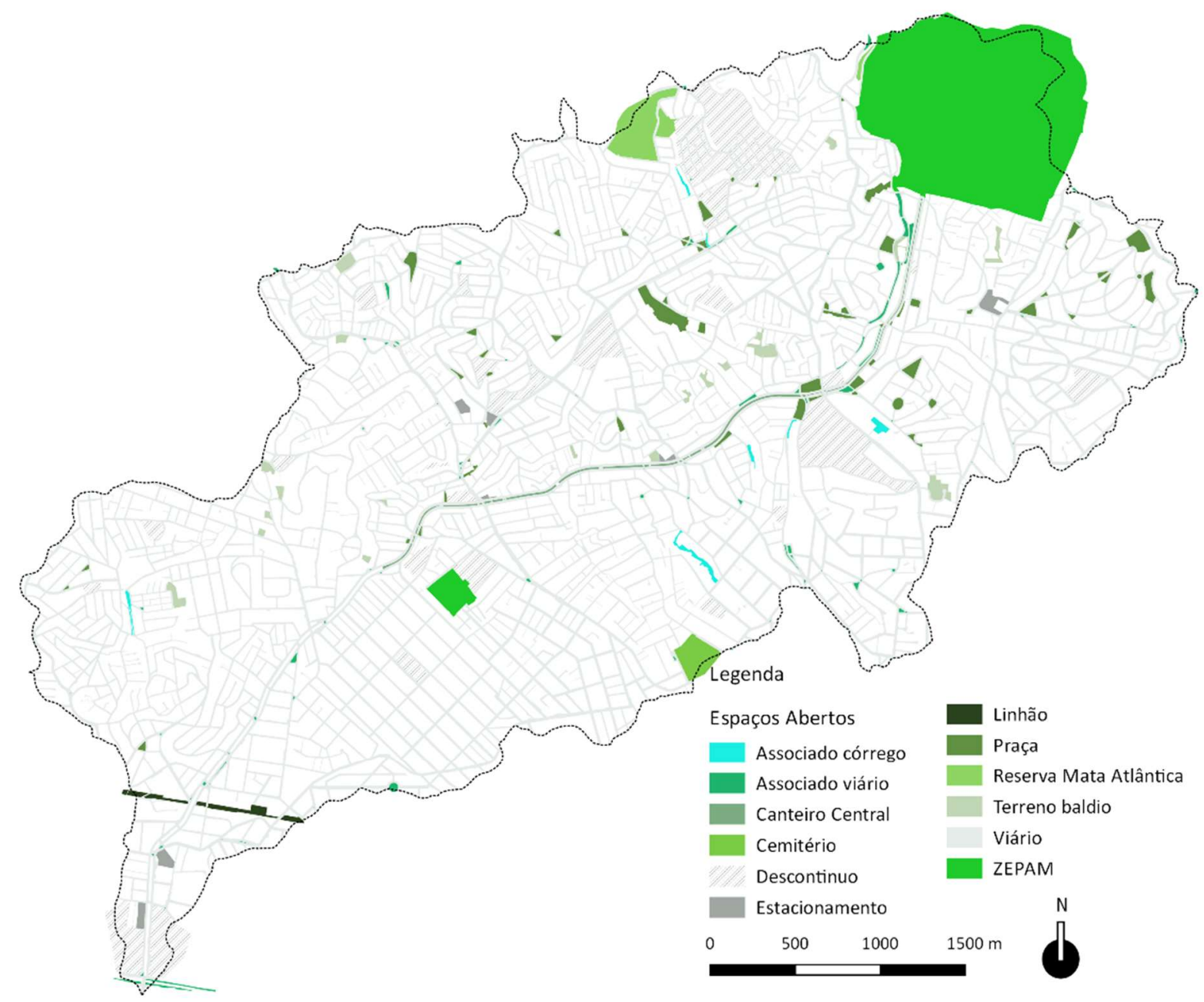

Fonte: elaborado pela autora. 
Figura 61: Compartimentação da Paisagem e Espaços Abertos.

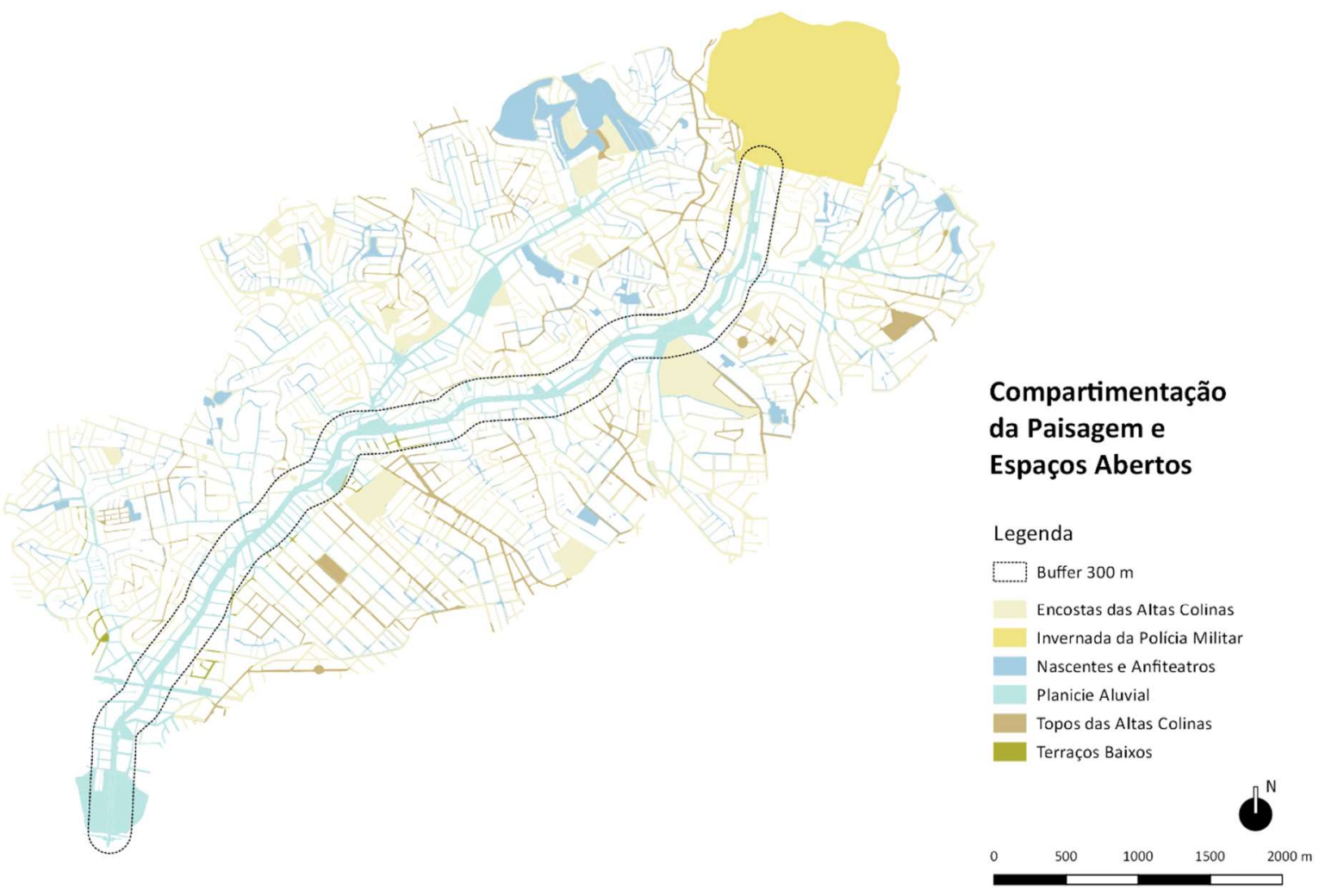

Fonte: elaborado pela autora.

Partimos do pressuposto que todos os Espaços Abertos são capazes de contribuir para o manejo das águas de chuva e, portanto, estão diretamente relacionados aos LID identificados para cada Compartimento da Paisagem. Paralelamente, consideramos o princípio Multifuncionalidade da IEV e identificamos outros serviços potencialmente prestados por cada tipo de Espaço Aberto. As escalas de análise foram definidas de acordo com o tamanho da área de estudo e a percepção física que se pretende ter para a bacia hidrográfica e o fundo de vale. Dessa forma, a escala da bacia foi abordada em 1:5.000 e a escala do fundo de vale em 1:2.000.

Cada uma das tipologias de Espaço Aberto indicadas anteriormente foi relacionada a "Abordagem das Quatro Naturezas" (ver Parte I- Subcapitulo 4.2; Figura 62), conforme segue: 
Tipo 1- Remanescentes Florestais: No Mandaqui e seu entorno imediato, essas áreas são representadas pelos Parques Estaduais da Cantareira e do Horto Florestal, e pelas áreas remanescentes da Mata Atlântica localizadas na Invernada da Polícia Militar e dentro da área ocupada pela Associação Irmãs Missionárias da Consolata, nas imediações do Horto.

Tipo 2- Paisagem Cultural: Esta tipologia é representada, na escala da bacia do Mandaqui, pela presença de uma Zona Especial de Proteção Ambiental (ZEPAM Niazi Chohfi) e ao longo do trecho aberto do córrego Água Preta.

Tipo 3- Jardins e Parques Urbanos: No Mandaqui, destacam-se as praças públicas acessíveis às pessoas, o canteiro central da avenida Eng. Caetano Álvares (Área Verde Associada ao Viário) e as áreas indicadas na tipologia 'Descontínuo' representadas por colégios. Os jardins do hospital do Mandaqui podem ser incluídos nessa tipologia, por sua acessibilidade, porém com a ressalva de ter o solo impermeabilizado. Quanto aos cemitérios, nos limites da bacia do Cabuçú de Baixo (oeste do Mandaqui) está um dos maiores da cidade, o Cemitério Vila Nova Cachoeirinha, com $350.000 \mathrm{~m}^{264}$, e no limite interno à bacia, a leste, se encontra o Cemitério de Santana (Chora Menino), com $38.485 \mathrm{~m}^{265}$, um dos mais antigos de São Paulo. Embora ambos sejam extensos e contenham áreas verdes que poderiam oferecer distintos benefícios urbanos, atualmente esses espaços não são acessíveis para uso público geral.

Tipo 4- Áreas em Transição: No estudo de caso essas tipologias estão presentes nos terrenos baldios, ao longo de áreas ribeirinhas de córregos ainda em estado natural não acessíveis, em lotes com construções abandonadas e em áreas verdes com pouca ou nenhuma manutenção, normalmente localizadas nos taludes mais íngremes da bacia e em alguns trechos sob o linhão. 0 tipo 4, engloba os espaços normalmente menos atrativos para as pessoas, podendo ser percebidos como áreas de insegurança urbana.

\footnotetext{
${ }^{64}$ Disponível em: <http://www.cemiterio.net/cemiterio-vila-nova-cachoeirinha/> Acessado em: 06/06/2019.

${ }^{65}$ Disponível em: <http://cemiteriodesantana.com.br/> Acessado em: 06/06/2019.
} 
Tipo 5- Infraestruturas Monofuncionais: são compostas pelo sistema viário (ruas e calçadas), pelos grandes estacionamentos, pelo trecho de canal concretado aberto do Mandaqui, (atual infraestrutura de drenagem), e parte das áreas sob o linhão, ocupadas por estacionamentos e pátios de manobras industriais. Embora esse conjunto de tipologias seja importante para a instalação da Infraestrutura Verde, (fomentando a interação verde-cinza), normalmente não é considerada nos cálculos de fornecimento dos Serviços Ecossistêmicos, focados apenas nas tipologias de áreas verdes e azuis.

Figura 62: aplicação da abordagem das 4 Naturezas na Bacia do Mandaqui.
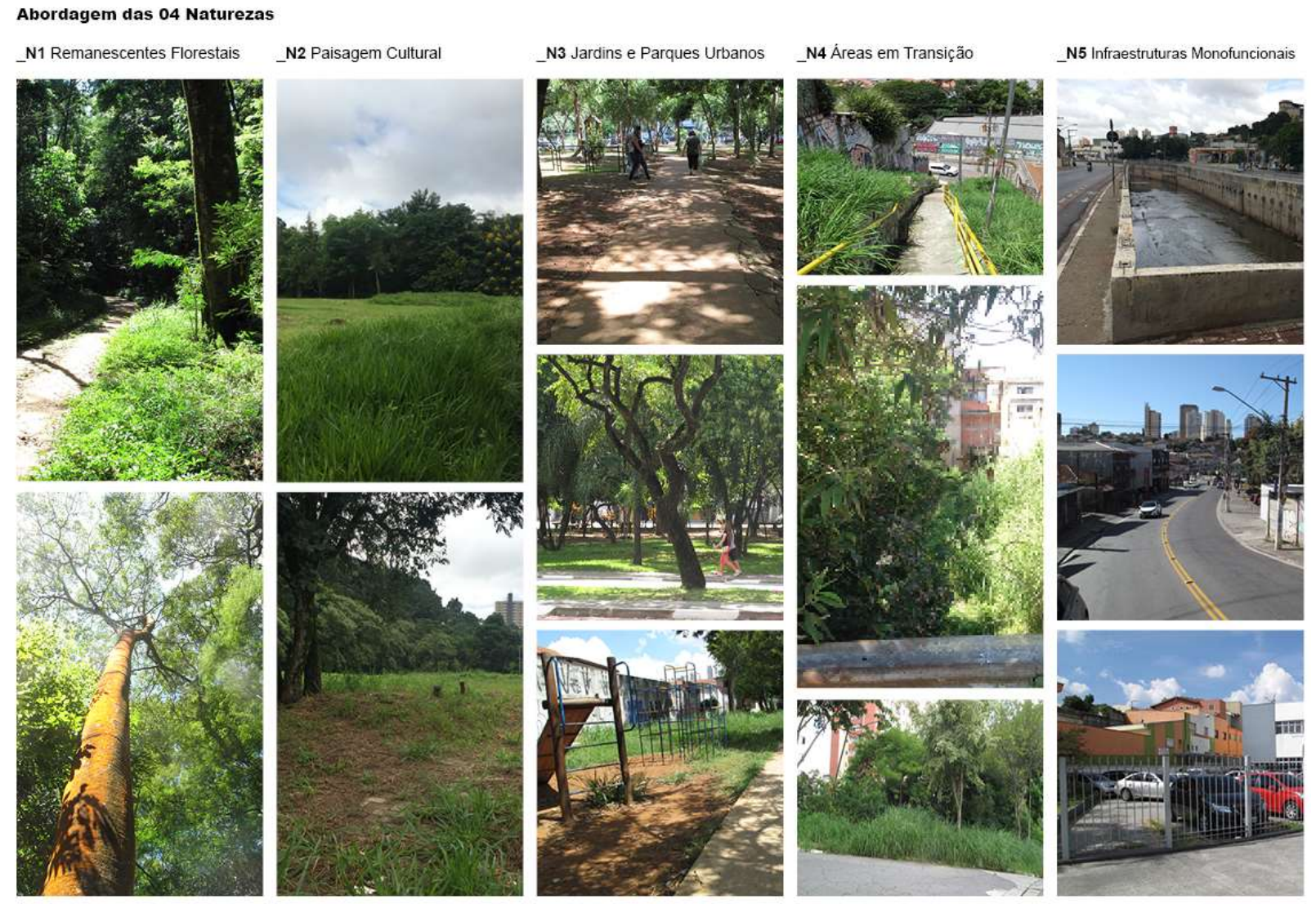

Fonte: elaborado pela autora. Fotografias da autora, tiradas durante os anos 2016, 2018 e 2019.

\subsection{APTIDÃO DOS ESPAÇOS ABERTOS EM FORNECER SERVIÇOS ECOSSISTÊMICOS}

A partir da classificação das tipologias de Espaços Abertos foi possível aplicar a matriz de aptidão em fornecer serviços ecossistêmicos de acordo com os diferentes usos de solo, baseados 
em Burkhard et al. (2012). A esse enquadramento foram adicionados os tipos de Espaços Abertos encontrados na bacia do Mandaqui, classificados quanto a sua origem ecológica, e a eles associados o fornecimento de distintos Serviços Ecossistêmicos urbanos com base nos resultados obtidos pela Compartimentação da Paisagem (relacionados a regulação hídrica), em revisão bibliográfica e visitas a campo. O nível de relevância de fornecimento de cada SE não foi considerado por envolver uma complexidade de geração de dados que necessitaria de equipe multidisciplinar para sua precisão. À tabela original foi adicionada a coluna "Mobilidade“ e o item Infraestrutura Monofuncionais (estacionamentos, vias e cursos d'água canalizados). A lista original de SE (BURKHARD et al. 2012) foi adaptada para a escala do estudo resultando na exclusão de alguns serviços não encontrados localmente, principalmente relacionados à provisão, além da inclusão de funções relacionadas à mobilidade. A sequência de Quadros 13, 14 e 15 apresenta a relação completa de Espaços Abertos encontrados na bacia do Mandaqui e relacionada à aptidão para fornecer diversos SE urbanos.

O fornecimento dos SE nos distintos Espaços Abertos poderá ser alterado a partir da instalação dos LID e conversão total ou parcial em áreas verdes desenhadas para lidar com a problemática das águas urbanas, ao mesmo tempo que suprem outras demandas ecossistêmicas. As maiores alterações poderão ser notadas nas estruturas monofuncionais. Por exemplo, estacionamentos poderão receber canteiros pluviais, pavimentos permeáveis e arborização, funcionando como áreas de reservação, melhorando o microclima local e contribuindo para a remoção de cargas difusas; lajes planas poderão receber tetos verdes habitáveis, beneficiando a regulação hídrica ao mesmo tempo que promovem a agricultura urbana e espaços de convivência. 
Quadro 13: Aptidão dos Espaços Abertos Tipos 1 e 2 em fornecer Serviços Ecossistêmicos e Funções Urbanas.

\begin{tabular}{|c|c|c|c|c|c|c|c|}
\hline & 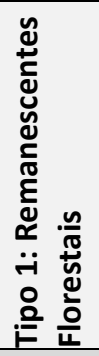 & 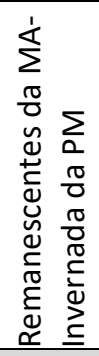 & 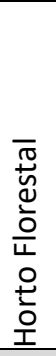 & $\begin{array}{l}\frac{\pi}{0} \\
\frac{0}{2} \\
\frac{\pi}{2} \\
\frac{1}{0} \\
0 \\
0 \\
\frac{\pi}{0} \\
0 \\
\frac{0}{0} \\
\frac{0}{\pi} \\
2\end{array}$ & 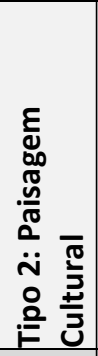 & $\underset{\substack{\mathrm{N} \\
\text { 岕 }}}{ }$ & Referências \\
\hline \multicolumn{8}{|l|}{ Habitat } \\
\hline Biodiversidade & & $x$ & $\mathrm{x}$ & $x$ & & $\mathrm{x}$ & NOWAK; DWYER, 2007 \\
\hline Cursos d'água bióticos & & $x$ & $\mathrm{x}$ & $x$ & & $x$ & \multirow{4}{*}{ BURKHARD et al. ,2012 } \\
\hline Eficiência metabólica & & $x$ & $\mathrm{x}$ & $x$ & & $\mathrm{x}$ & \\
\hline Captação de Radiação & & $x$ & $\mathrm{x}$ & $x$ & & $x$ & \\
\hline $\begin{array}{l}\text { Redução de perdas de } \\
\text { nutrientes }\end{array}$ & & $x$ & $\mathrm{x}$ & $x$ & & $x$ & \\
\hline \multicolumn{8}{|l|}{ Serviços de Provisão } \\
\hline Agricultura urbana & & 0 & 0 & 0 & & 0 & - \\
\hline Energia & & $x$ & $x$ & $x$ & & 0 & NOWAK; DWYER, 2007 \\
\hline Água fresca & & $x$ & 0 & 0 & & 0 & BURKHARD et al. ,2012 \\
\hline \multicolumn{8}{|l|}{ Serviços de Regulação } \\
\hline Proteção a enchentes & & $x$ & $\mathrm{x}$ & $x$ & & $\mathrm{x}$ & BURKHARD et al. ,2012 \\
\hline $\begin{array}{l}\text { Amortização de escoamento } \\
\text { superficial }\end{array}$ & & $x$ & $x$ & $x$ & & $x$ & \multirow{5}{*}{ NOWAK; DWYER, 2007} \\
\hline Recarga de aquíferos & & $x$ & $\mathrm{x}$ & $x$ & & $\mathrm{x}$ & \\
\hline Regulação da Qualidade do ar & & $x$ & $x$ & $x$ & & $\mathrm{x}$ & \\
\hline Mitigação de ruído & & $x$ & $\mathrm{x}$ & $x$ & & $\mathrm{x}$ & \\
\hline Controle da erosão & & $x$ & $x$ & $x$ & & $x$ & \\
\hline Regulação de nutrientes & & $x$ & $\mathrm{x}$ & $x$ & & $\mathrm{x}$ & BURKHARD et al. ,2012 \\
\hline Descontaminação das águas & & $x$ & $\mathrm{x}$ & $x$ & & $x$ & NOWAK; DWYER, 2007 \\
\hline $\begin{array}{l}\text { Polinização e dispersão de } \\
\text { sementes }\end{array}$ & & $x$ & $x$ & $x$ & & $x$ & BURKHARD et al. ,2012 \\
\hline Regulação do microclima & & $x$ & $x$ & $x$ & & & $\begin{array}{l}\text { NOWAK; DWYER, 2007; } \\
\text { DOBBERT et al., } 2017\end{array}$ \\
\hline \multicolumn{8}{|l|}{ Serviços Culturais } \\
\hline $\begin{array}{l}\text { Recreação e desenvolvimento } \\
\text { cognitivo }\end{array}$ & & 0 & $x$ & $x$ & & $x$ & KAPLAN e KAPLAN,1985; \\
\hline Valores estéticos & & 0 & $x$ & 0 & & $x$ & KAPLAN e KAPLAN,1985; \\
\hline Educação ambiental & & 0 & $\mathrm{x}$ & $\mathrm{x}$ & & $x$ & - \\
\hline \multicolumn{8}{|l|}{ Funções de Mobilidade } \\
\hline Mob. ativa-caminhada & & 0 & $x$ & $x$ & & $x$ & - \\
\hline Mob. ativa-bicicleta & & 0 & 0 & 0 & & 0 & - \\
\hline Transporte público & & 0 & 0 & 0 & & 0 & - \\
\hline Transporte privado & & 0 & 0 & 0 & & 0 & - \\
\hline
\end{tabular}

Fonte: elaborado pela autora a partir de pesquisa bibliográfica e observações em campo (OC). 
Quadro 14: Aptidão dos Espaços Abertos Tipos 3 em fornecer Serviços Ecossistêmicos e Funções Urbanas.

\begin{tabular}{|c|c|c|c|c|c|c|}
\hline & 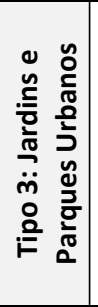 & 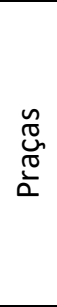 & 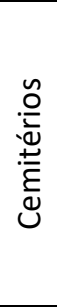 & 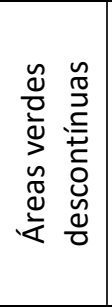 & 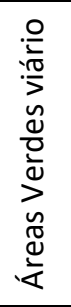 & Referências \\
\hline \multicolumn{7}{|l|}{ Habitat } \\
\hline Biodiversidade & & $x$ & 0 & 0 & 0 & NOWAK; DWYER, 2007 \\
\hline Cursos d'água bióticos & & 0 & 0 & 0 & 0 & - \\
\hline Eficiência metabólica & & 0 & 0 & 0 & 0 & - \\
\hline Captação de Radiação & & $x$ & 0 & 0 & 0 & BURKHARD et al. ,2012 \\
\hline Redução de perdas de nutrientes & & 0 & 0 & 0 & 0 & - \\
\hline \multicolumn{7}{|l|}{ Serviços de Provisão } \\
\hline Agricultura urbana & & $x$ & 0 & $x$ & $x$ & - \\
\hline Energia & & 0 & 0 & 0 & 0 & - \\
\hline Água fresca & & 0 & 0 & 0 & 0 & - \\
\hline \multicolumn{7}{|l|}{ Serviços de Regulação } \\
\hline Proteção a enchentes & & $x$ & 0 & $x$ & $x$ & FCTH, 2017 \\
\hline $\begin{array}{l}\text { Amortização de escoamento } \\
\text { superficial }\end{array}$ & & $\mathrm{x}$ & $\mathrm{x}$ & 0 & 0 & FCTH, 2017 \\
\hline Recarga de aquíferos & & $x$ & 0 & $x$ & $x$ & NOWAK; DWYER, 2007 \\
\hline Regulação da Qualidade do ar & & $x$ & $x$ & $x$ & $x$ & NOWAK; DWYER, 2007 \\
\hline Mitigação de ruído & & $\mathrm{x}$ & $x$ & $x$ & $\mathrm{x}$ & NOWAK; DWYER, 2007 \\
\hline Controle da erosão & & $x$ & 0 & $x$ & $x$ & $\mathrm{OC}$ \\
\hline Regulação de nutrientes & & 0 & 0 & 0 & 0 & - \\
\hline Descontaminação das águas & & $x$ & $x$ & $x$ & $x$ & FCTH, 2017 \\
\hline Polinização e dispersão de sementes & & $x$ & 0 & $x$ & $x$ & NOWAK; DWYER, 2007 \\
\hline Regulação do microclima & & $x$ & $x$ & $x$ & $x$ & DUARTE et al., 2015 \\
\hline \multicolumn{7}{|l|}{ Serviços Culturais } \\
\hline $\begin{array}{l}\text { Recreação e desenvolvimento } \\
\text { cognitivo }\end{array}$ & & $x$ & 0 & 0 & $x$ & - \\
\hline Valores estéticos & & $x$ & 0 & 0 & 0 & - \\
\hline Educação ambiental & & 0 & 0 & 0 & 0 & - \\
\hline \multicolumn{7}{|l|}{ Funções de Mobilidade } \\
\hline Mob. ativa-caminhada & & $x$ & 0 & $x$ & $x$ & - \\
\hline Mob. ativa-bicicleta & & 0 & 0 & 0 & $x$ & - \\
\hline Transporte público & & 0 & 0 & 0 & 0 & - \\
\hline Transporte privado & & 0 & 0 & 0 & 0 & - \\
\hline
\end{tabular}

Fonte: elaborado pela autora a partir de pesquisa bibliográfica e observações em campo (OC). 
Quadro 15: Aptidão dos Espaços Abertos Tipos 4 e 5 em fornecer Serviços Ecossistêmicos e Funções Urbanas.

\begin{tabular}{|c|c|c|c|c|c|c|c|c|c|}
\hline & 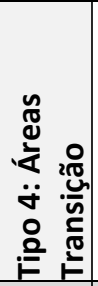 & 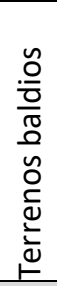 & 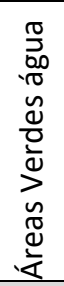 & $\frac{2}{2 \pi}$ & 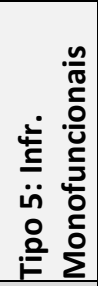 & 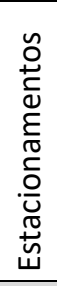 & $\stackrel{\circ}{: \frac{0}{10}}$ & $\begin{array}{l}0 \\
\frac{0}{0} \\
\frac{\pi}{N} \\
\frac{N}{\pi} \\
\frac{1}{0} \\
0 \\
0 \\
0 \\
0 \\
0 \\
0 \\
0 \\
0\end{array}$ & Referências \\
\hline \multicolumn{10}{|l|}{ Habitat } \\
\hline Biodiversidade & & 0 & 0 & 0 & & 0 & 0 & 0 & - \\
\hline Cursos d'água bióticos & & 0 & 0 & 0 & & 0 & 0 & 0 & - \\
\hline Eficiência metabólica & & 0 & 0 & 0 & & 0 & 0 & 0 & - \\
\hline Captação de Radiação & & 0 & 0 & 0 & & 0 & 0 & 0 & - \\
\hline Redução de perdas de nutrientes & & 0 & 0 & 0 & & 0 & 0 & 0 & - \\
\hline \multicolumn{10}{|l|}{ Serviços de Provisão } \\
\hline Agricultura urbana & & 0 & 0 & $x$ & & 0 & 0 & 0 & \multirow{2}{*}{$\begin{array}{c}\text { OC- Sinergia com } \\
\text { fornecimento de energia } \\
\text { elétrica. }\end{array}$} \\
\hline Energia & & 0 & 0 & $\mathrm{x}$ & & 0 & 0 & 0 & \\
\hline Água fresca & & 0 & 0 & 0 & & 0 & 0 & 0 & - \\
\hline \multicolumn{10}{|l|}{ Serviços de Regulação } \\
\hline Proteção a enchentes & & 0 & 0 & 0 & & 0 & 0 & 0 & FCTH, 2017 \\
\hline $\begin{array}{l}\text { Amortização de escoamento } \\
\text { superficial }\end{array}$ & & $\mathrm{x}$ & 0 & $\mathrm{x}$ & & 0 & 0 & 0 & FCTH, 2017 \\
\hline Recarga de aquíferos & & $x$ & 0 & $x$ & & 0 & 0 & 0 & - \\
\hline Regulação da Qualidade do ar & & 0 & 0 & 0 & & 0 & 0 & 0 & - \\
\hline Mitigação de ruído & & 0 & 0 & 0 & & 0 & 0 & 0 & - \\
\hline Controle da erosão & & $x$ & 0 & $x$ & & 0 & 0 & 0 & - \\
\hline Regulação de nutrientes & & 0 & 0 & 0 & & 0 & 0 & 0 & - \\
\hline Descontaminação das águas & & $x$ & $x$ & $x$ & & 0 & 0 & 0 & FCTH, 2017 \\
\hline $\begin{array}{l}\text { Polinização e dispersão de } \\
\text { sementes }\end{array}$ & & 0 & 0 & 0 & & 0 & 0 & 0 & NOWAK; DWYER, 2007 \\
\hline Regulação do microclima & & 0 & $x$ & 0 & & 0 & 0 & 0 & DUARTE et al., 2015 \\
\hline \multicolumn{10}{|l|}{ Serviços Culturais } \\
\hline $\begin{array}{l}\text { Recreação e desenvolvimento } \\
\text { cognitivo }\end{array}$ & & 0 & 0 & $x$ & & 0 & 0 & 0 & $\begin{array}{c}\text { OC- Sinergia à agricultura } \\
\text { urbana }\end{array}$ \\
\hline Valores estéticos & & 0 & 0 & 0 & & 0 & 0 & 0 & - \\
\hline Educação ambiental & & 0 & 0 & 0 & & 0 & 0 & 0 & - \\
\hline \multicolumn{10}{|l|}{ Funções de Mobilidade } \\
\hline Mob. ativa-caminhada & & 0 & 0 & 0 & & 0 & $x$ & $x$ & - \\
\hline Mob. ativa-bicicleta & & 0 & 0 & 0 & & 0 & $x$ & $x$ & - \\
\hline Transporte público & & 0 & 0 & 0 & & 0 & $x$ & $x$ & - \\
\hline Transporte privado & & 0 & 0 & 0 & & $x$ & $x$ & $x$ & - \\
\hline
\end{tabular}

Fonte: elaborado pela autora a partir de pesquisa bibliográfica e observações em campo (OC). 
Quanto aos desserviços que podem estar atrelados tanto aos Espaços Abertos quanto aos LID instalados, sua identificação estará em parte atrelada às relações socioecológicas, dependentes da percepção das pessoas quanto às características dos espaços (LYYTIMÄKI; SIPILÄ, 2009). É possível apresentar um panorama dos desserviços já estudados em áreas urbanas e sugerir algumas ações genéricas (Quadro 16). Outra questão relevante na bacia do Mandaqui, embora não considerada um desserviço, é a presença de população moradora de rua ocupando praças e terrenos baldios, uma problemática social crítica que merece atenção imediata do poder público.

Quadro 16: Desserviços Ecossistêmicos no Mandaqui.

\begin{tabular}{|c|c|c|c|}
\hline Desserviço & Exemplos & Referência & Ações sugeridas \\
\hline Qualidade do ar & Emissão de COVs & $\begin{array}{l}\text { GÓMEZ-BAGGETHUN; } \\
\text { BARTON, } 2013\end{array}$ & $\begin{array}{c}\text { Escolha adequada de } \\
\text { espécies }\end{array}$ \\
\hline $\begin{array}{l}\text { Bloqueio de } \\
\text { visuais }\end{array}$ & $\begin{array}{l}\text { Proximidade de grandes árvores aos } \\
\text { edifícios pode bloquear visuais }\end{array}$ & LYYTIMÄKI; SIPILÄ, 2007 & $\begin{array}{c}\text { Respeito às distancias } \\
\text { mínimas necessárias para } \\
\text { cada espécie arbórea }\end{array}$ \\
\hline Alergias & $\begin{array}{l}\text { Processos de polinização através do } \\
\text { vento podem causar reações alérgicas }\end{array}$ & $\begin{array}{l}\text { GÓMEZ-BAGGETHUN; } \\
\text { BARTON, } 2013\end{array}$ & $\begin{array}{c}\text { Escolha adequada de } \\
\text { espécies }\end{array}$ \\
\hline \multirow{2}{*}{ Acidentes } & $\begin{array}{l}\text { Queda de galhos das árvores sobre as } \\
\text { ruas, casas e calçadas }\end{array}$ & $\begin{array}{l}\text { GÓMEZ-BAGGETHUN; } \\
\text { BARTON, } 2013\end{array}$ & Manejo arbóreo adequado \\
\hline & $\begin{array}{l}\text { Queda por escorregamento em } \\
\text { calçada devido a flores e frutos }\end{array}$ & OC & $\begin{array}{l}\text { Escolha adequada de } \\
\text { espécies }\end{array}$ \\
\hline \multirow{2}{*}{$\begin{array}{l}\text { Sensações de } \\
\text { medo e stress }\end{array}$} & $\begin{array}{c}\text { Relacionado ao bloqueio da } \\
\text { iluminação pública pelas copas das } \\
\text { árvores }\end{array}$ & LYYTIMÄKI; SIPILÄ, 2007 & $\begin{array}{l}\text { Escolha adequada das } \\
\text { espécies; adequação da } \\
\text { iluminação pública }\end{array}$ \\
\hline & $\begin{array}{l}\text { Relacionada à falta de manutenção } \\
\text { das áreas verdes }\end{array}$ & OC & $\begin{array}{l}\text { Adequada manutenção e } \\
\text { plano de manejo arbóreo }\end{array}$ \\
\hline \multirow{3}{*}{$\begin{array}{l}\text { Danos às } \\
\text { infraestruturas }\end{array}$} & $\begin{array}{l}\text { Rompimento de pavimentos pelas } \\
\text { raízes; ação micro biótica }\end{array}$ & LYYTIMÄKI; SIPILÄ, 2007 & \multirow{3}{*}{$\begin{array}{l}\text { Escolha adequada de } \\
\text { espécies; respeito às } \\
\text { distâncias mínimas de } \\
\text { plantio; plano de manejo } \\
\text { arbóreo }\end{array}$} \\
\hline & $\begin{array}{c}\text { Danos causados pelas raízes das } \\
\text { árvores nas infraestruturas } \\
\text { subterrâneas }\end{array}$ & OC & \\
\hline & $\begin{array}{l}\text { Danos causados pelos galhos das } \\
\text { árvores nas infraestruturas aéreas }\end{array}$ & OC & \\
\hline $\begin{array}{l}\text { Competição por } \\
\text { habitat com } \\
\text { humanos }\end{array}$ & $\begin{array}{c}\text { Animais e insetos percebidos como } \\
\text { perigosos e/ou asquerosos }\end{array}$ & $\begin{array}{l}\text { GÓMEZ-BAGGETHUN; } \\
\text { BARTON, } 2013\end{array}$ & $\begin{array}{l}\text { Escolha adequada de } \\
\text { espécies; adequada } \\
\text { manutenção }\end{array}$ \\
\hline
\end{tabular}

Fonte: elaborado pela autora a partir de GÓMEZ-BAGGETHUN; BARTON, (2013) e Observações em Campo (OC). 


\subsection{SINERGIAS, TRADE OFFS E DESSERVIÇOS NO FUNDO DE VALE}

Conforme introduzido nos capítulos anteriores, o fundo de vale do córrego Mandaqui, quando ao longo da avenida Eng. ${ }^{\circ}$ Caetano Álvares, agrega infraestruturas de mobilidade, verde (parcialmente) e drenagem, contando com um trecho canalizado aberto e outro subterrâneo, em galerias. A relação entre a situação do canal e a presença de vegetação é paradoxal. Se em estado natural as áreas verdes acompanham as margens dos cursos d'água, no estudo de caso elas só estão presentes devido à supressão das águas e o trecho aberto é completamente árido, inacessível visualmente e acessível fisicamente sem segurança ao pedestre devido à faixa de calçada rente ao leito carroçável de menos de $1 \mathrm{~m}$ de largura (Figura 63). Originalmente, as áreas verdes e azuis da várzea funcionavam em sinergia, adaptando-se às dinâmicas hidrológicas, atualmente essas duas infraestruturas estão isoladas e funcionam de modo autônomo.

Figura 63: paradoxo do verde e azul no vale do Mandaqui.

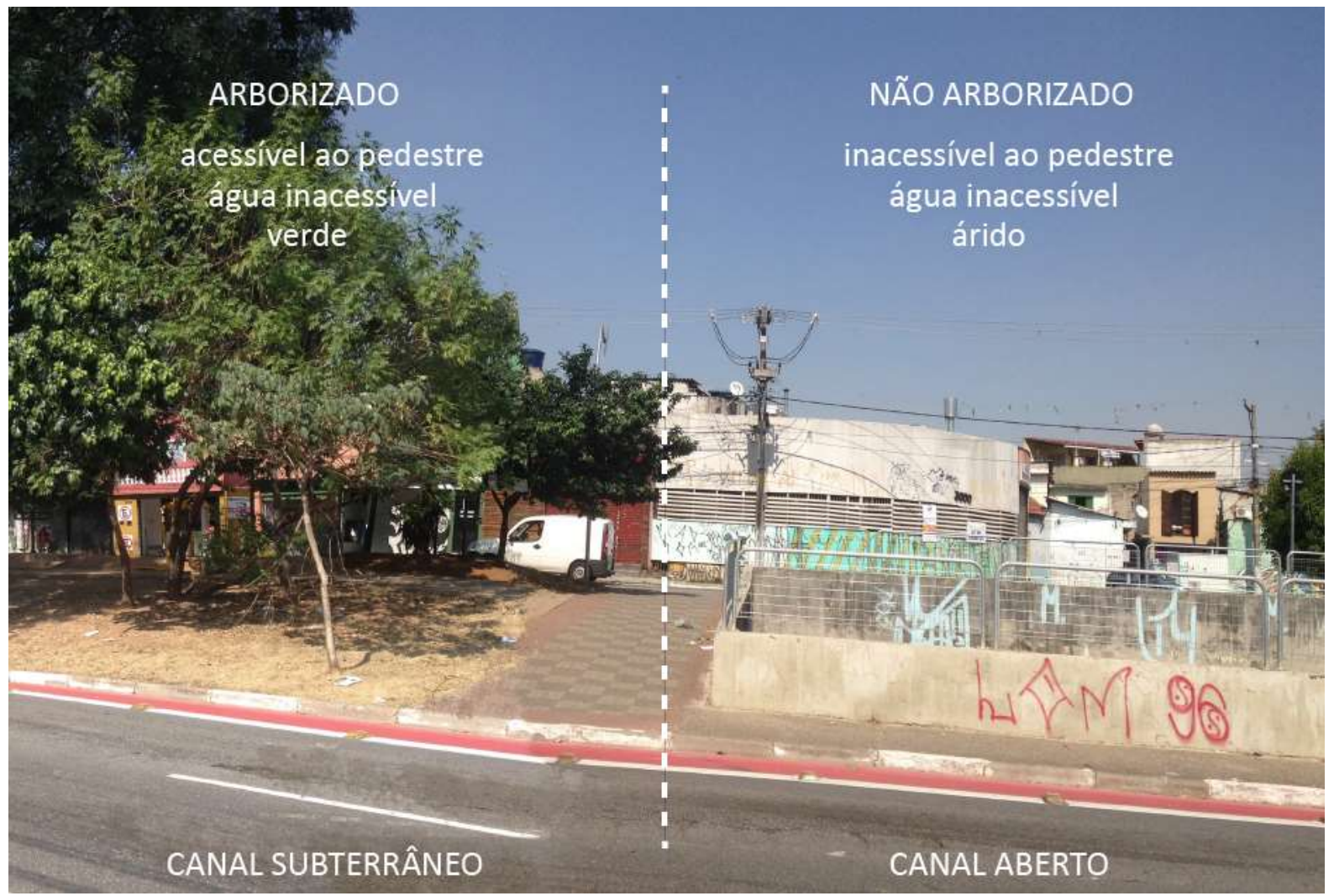

Fonte: elaborado pela autora. 
Não é porque as infraestruturas dividem o mesmo espaço que o eixo possui um caráter multifuncional, ao invés disso, existem distintas funções espacialmente sobrepostas ou paralelas. Os termos sinergia, trade-offs e desserviços normalmente não sejam aplicados às infraestruturas tradicionais, devido ao seu caráter monofuncional e por usualmente não serem consideradas em valorações dos SE. Uma vez que consideramos as integrações verde-cinza como fomento à transição para Eixos Multifuncionais, essas relações serão revistas, a fim de futuramente podermos enfatizar as sinergias e reduzir os trade-offs e desserviços.

A partir dos três cortes transversais ao eixo, posicionados um em cada porção da bacia (superior, médio e inferior, ver Figura 29, Parte II- Capítulo 2), foi verificada a proporção de espaço superficial que as infraestruturas vêm ocupando no vale, ao longo do tempo. Esse entendimento espacial, representado por 03 tipologias gerais, aporta as contradições existentes e alerta para possíveis desserviços (Figura 64). As integrações potenciais poderão ser propostas a partir do entendimento dessas problemáticas e das possibilidades encontradas nos distintos Espaços Abertos caracterizados anteriormente e sobrepostos aos Compartimentos da Paisagem.

Figura 64: Distribuição das áreas do eixo entre as infraestruturas principais.
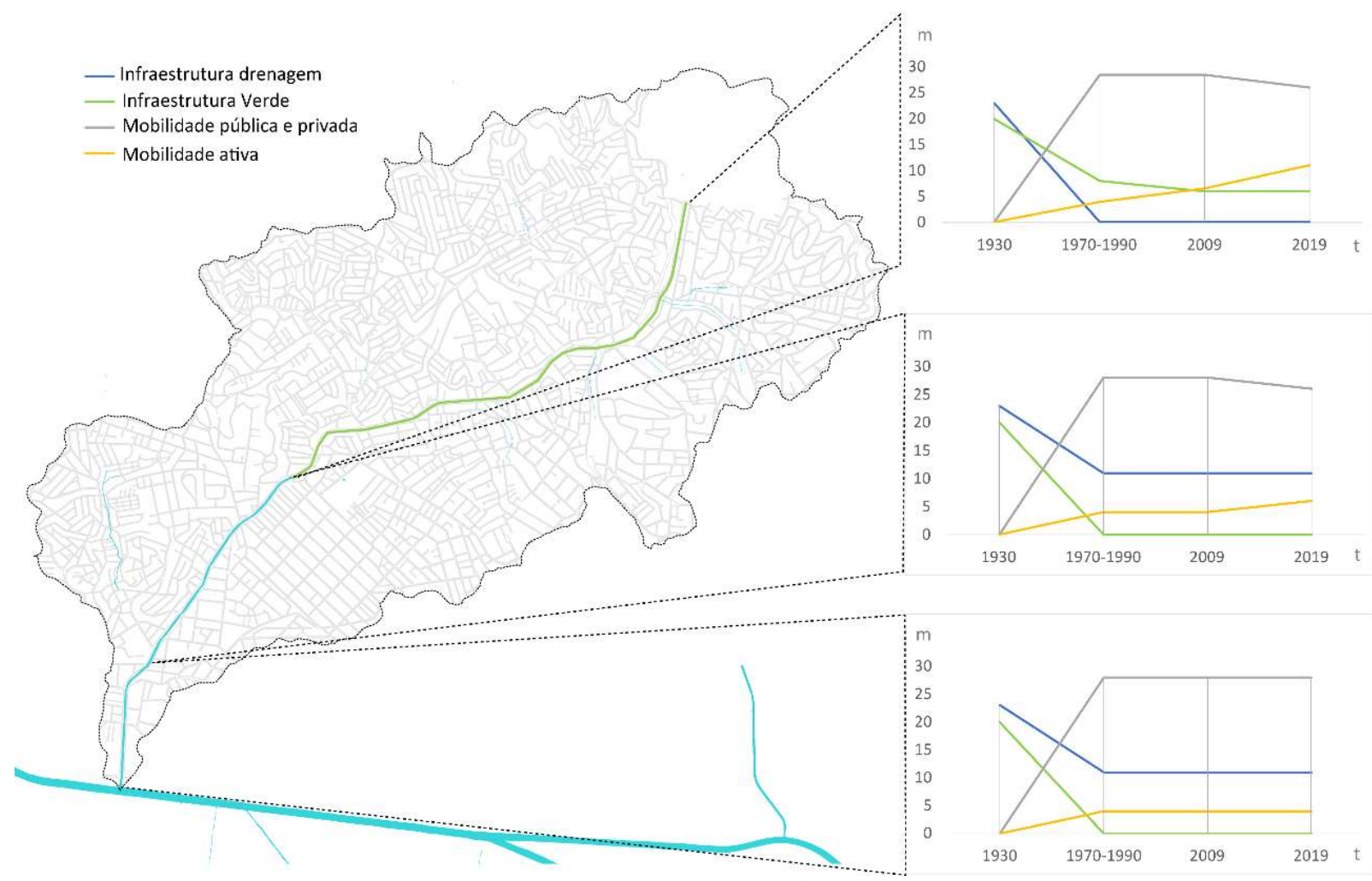

Fonte: elaborado pela autora.

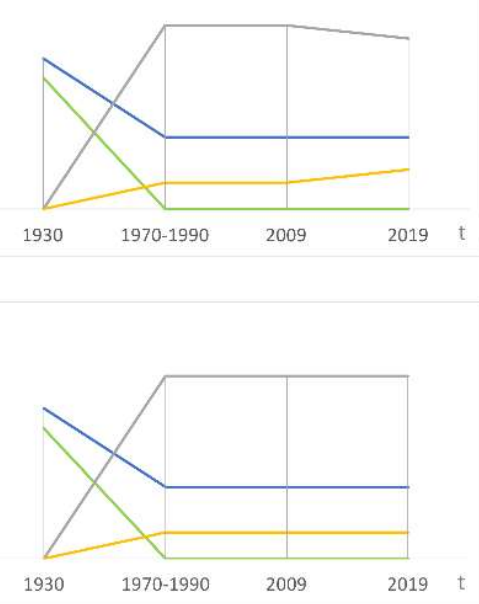


A influência das áreas de Encostas na Planície é responsável por alterações nos níveis das pistas à esquerda e à direita do canal, ocasionando a criação de taludes ao longo do canteiro central de até aproximadamente 1,8 $\mathrm{m}$ de altura, que limitam os passeios pedonais e as ciclovias, ao mesmo tempo que conservam uma certa largura verde mínima (Figuras 65, 66 e 67).

Figura 65, 66 e 67: Variação de altura entre as pistas da avenida. Exemplo no trecho superior da bacia (esq.) e médio (dir.), com cortes esquemáticos das distintas tipologias (abaixo).
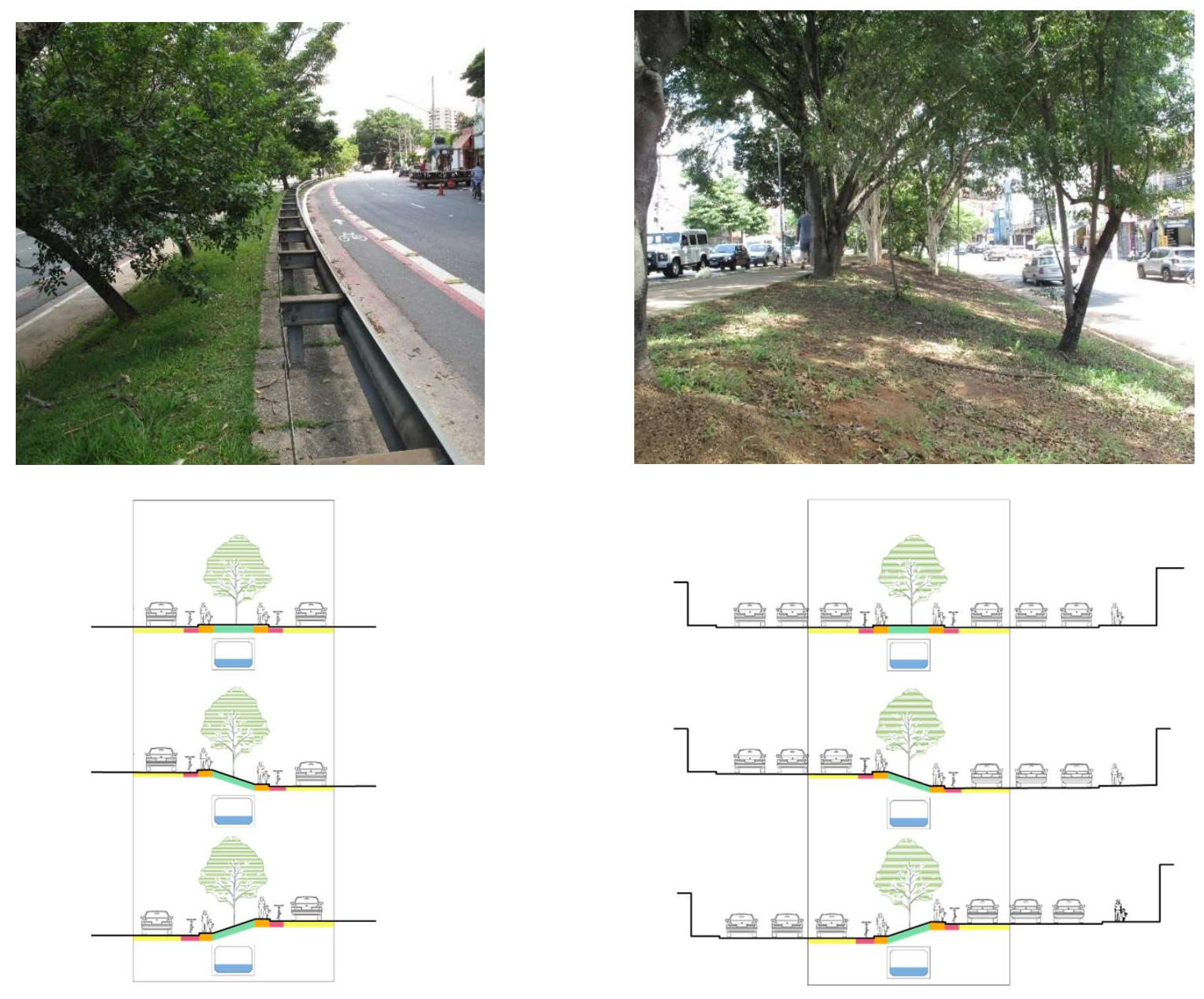

Fonte: Figura 68, 69, autora (2018); Figura 70: elaborado pela autora.

As áreas verdes, inicialmente instaladas de modo a permitir eventuais reparos nas galerias de drenagem, sem afetar o fluxo veicular, atualmente promovem SE culturais e de regulação microclimática de forma sinérgica, dando suporte para que modos de mobilidade ativa possam ocorrer no fundo de vale. O canal em concreto, fechado ou aberto, contribui para a regulação do volume, mas gera o desserviço relacionado à qualidade das águas, uma vez que não possui nenhum agente de remoção ou tratamento dos contaminantes carreados pelas chuvas ou 
lançados diretamente aos córregos. Sua principal sinergia está relacionada à mobilidade, pois tem como parte de seus objetivos construtivos, garantir que não haja inundações nas pistas marginais. Este também pode ser considerado seu principal trade-off, uma vez que a ocorrência de inundações das pistas da avenida tem se tornado cada vez mais frequente, resultado da saturação do sistema de drenagem.

As pistas de rolamento são responsáveis por garantir que o transporte público e privado flua pelo vale, mas acarretaram o tamponamento do córrego, reduzindo sua área de inundação e gerando uma série de desserviços, relacionados tanto à qualidade das águas (carreamento da contaminação difusa para os córregos), quanto à qualidade do ar, perda de habitat e alterações no microclima, além dos trade-offs associados à impossibilidade da várzea em fornecer uma série de SE. Além disso, é um sistema saturado por veículos ao longo do dia, o que infere um desafio à própria função inicial desta infraestrutura e indica a necessidade urgente de repensarmos as formas de mobilidade na bacia. No Quadro 17 as sinergias, trade-offs e desserviços entre as infraestruturas são relacionadas.

A potencial integração das infraestruturas de fundo de vale, a fim de potencializar as sinergias e reduzir trade-offs e desserviços para formar um Eixo Multifuncional, dependerá das dinâmicas encontradas nas quadras e vias lindeiras, além de uma visão na escala da bacia hidrográfica, como vimos reforçando ao longo da pesquisa, que repense as condições de mobilidade como fator chave para uma melhora da qualidade dos Espaços Abertos e da incorporação dos sistemas de áreas verdes provedoras de distintos SE. Os lotes lindeiros à avenida possuem diversos usos do solo, variando do predomínio de ocupação por galpões industriais dedicados a lojas e oficinas mecânicas (ver Parte II- Capítulo 2), nas porções inferior e média, ao predomínio das áreas de comércios mais variado, residências e áreas verdes em direção à porção superior do vale. A identificação dos compartimentos da paisagem nos permitiu compreender a relação topográfica entre as áreas da Planície Aluvial e das Encostas das Altas Colinas, assim como o desenho sinuoso de vias que acompanham ou cruzam perpendicularmente as curvas de nível da bacia. Essas características agregam uma dificuldade à liberação da Planície Aluvial para a Infraestrutura Verde, pois desafiam a distribuição dos fluxos veiculares a partir da avenida Eng ${ }^{\circ}$. Caetano Álvares a vias paralelas em áreas sem risco de inundação. 
Quadro 17: Sinergias, Trade-offs e desserviços entre as infraestruturas no fundo de vale do Mandaqui.

\begin{tabular}{|c|c|c|c|c|}
\hline Impactado & Transporte público e & Mobilidade ativa & IEV- Canteiro & Drenagem \\
\hline Impacta & privado & & central & \\
\hline \multirow{3}{*}{ Drenagem } & S_Proteção às enchentes & $\begin{array}{l}\text { S_Trecho fechado- favorece } \\
\text { mobilidade ativa }\end{array}$ & $\begin{array}{l}\text { S_Ocorrem em } \\
\text { camadas distintas }\end{array}$ & \multirow{3}{*}{ não se aplica } \\
\hline & $\begin{array}{l}\text { T_Saturação- enchentes } \\
\text { impossibilita circulação }\end{array}$ & $\begin{array}{l}\text { T_trecho aberto- sem } \\
\text { caminho pedonal; redução e } \\
\text { insegurança da ciclofaixa }\end{array}$ & $\begin{array}{l}\text { T_ Trecho aberto- } \\
\text { não há área verde }\end{array}$ & \\
\hline & D_não se aplica & D_não se aplica & $\begin{array}{l}\text { D_Limitação do } \\
\text { espaço para raízes }\end{array}$ & \\
\hline \multirow[b]{2}{*}{$\begin{array}{l}\text { IEV- } \\
\text { Canteiro } \\
\text { Central }\end{array}$} & $\begin{array}{l}\text { S_Valores estéticos } \\
\text { tornam viagens } \\
\text { agradáveis }\end{array}$ & $\begin{array}{l}\text { S_SE de Regulação e Cultural } \\
\text { beneficiam os modos ativos }\end{array}$ & \multirow{3}{*}{ não se aplica } & $\begin{array}{l}\text { S_Amortização } \\
\text { da chuva pelo } \\
\text { dossel arbóreo }\end{array}$ \\
\hline & T_não se aplica & $\begin{array}{l}\text { T_Inclinação do canteiro } \\
\text { reduz área pedonal e dificulta } \\
\text { o trânsito de pessoas }\end{array}$ & & $\begin{array}{l}\text { T_Folhas e } \\
\text { galhos } \\
\text { prejudicam } \\
\text { escoamento } \\
\text { pelas bocas de } \\
\text { lobo }\end{array}$ \\
\hline $\begin{array}{l}\text { IEV- } \\
\text { Canteiro } \\
\text { Central }\end{array}$ & $\begin{array}{l}\text { D_Raízes danificam } \\
\text { leitos carroçáveis e } \\
\text { galhos caídos podem } \\
\text { causar acidentes }\end{array}$ & $\begin{array}{l}\text { D_Raízes danificam pisos e } \\
\text { galhos causam acidentes; } \\
\text { espécies inadequadas tornam } \\
\text { vias escorregadias; pode } \\
\text { gerar sensação de medo }\end{array}$ & & $\begin{array}{l}\text { D_Raízes } \\
\text { podem } \\
\text { danificar } \\
\text { galerias de } \\
\text { drenagem }\end{array}$ \\
\hline \multirow{3}{*}{$\begin{array}{l}\text { Mobilidade } \\
\text { a pé e } \\
\text { bicicleta }\end{array}$} & $\begin{array}{l}\text { S_Ciclofaixas ao longo do } \\
\text { leito carroçável }\end{array}$ & \multirow{3}{*}{ não se aplica } & $\begin{array}{l}\text { S_Integração ao } \\
\text { longo do canteiro } \\
\text { central }\end{array}$ & \multirow{3}{*}{ não se aplica } \\
\hline & $\begin{array}{l}\text { T_Redução de largura de } \\
\text { leito carroçável }\end{array}$ & & T_não se aplica & \\
\hline & D_não se aplica & & $\begin{array}{l}\text { D_Pavimentação } \\
\text { de áreas } \\
\text { permeáveis }\end{array}$ & \\
\hline \multirow{3}{*}{$\begin{array}{l}\text { Transporte } \\
\text { público e } \\
\text { privado }\end{array}$} & \multirow{3}{*}{ não se aplica } & $\begin{array}{l}\text { S_Ciclofaixas ao longo do } \\
\text { leito carroçável }\end{array}$ & S_não se aplica & $\begin{array}{l}\text { S_Escoamento } \\
\text { superficial por } \\
\text { sarjetas e } \\
\text { bocas de lobo }\end{array}$ \\
\hline & & $\begin{array}{l}\text { T_Limita a quantidade de } \\
\text { bicicletas e pedestres em } \\
\text { alguns trechos devido ao } \\
\text { estreitamento das vias } \\
\text { exclusivas }\end{array}$ & $\begin{array}{l}\text { T_Limita a } \\
\text { quantidade e } \\
\text { qualidade e o } \\
\text { fornecimento de } \\
\text { SE de regulação } \\
\text { hídrica }\end{array}$ & $\begin{array}{l}\text { T_Supressão } \\
\text { da várzea e do } \\
\text { conjunto de SE } \\
\text { prestados }\end{array}$ \\
\hline & & $\begin{array}{l}\text { D_Contaminação } \\
\text { atmosférica; proximidade às } \\
\text { calçadas e ciclofaixas gera } \\
\text { sentimento de insegurança }\end{array}$ & $\begin{array}{l}\text { D_Contaminação } \\
\text { atmosférica } \\
\text { acarreta } \\
\text { enfermidades na } \\
\text { vegetação }\end{array}$ & $\begin{array}{l}\text { D_Contaminaç } \\
\text { ão difusa } \\
\text { carreada pelas } \\
\text { primeiras } \\
\text { chuvas }\end{array}$ \\
\hline
\end{tabular}

Fonte: elaborado pela autora. 
A Figura 68 apresenta a delimitação de trechos onde, a partir do sistema viário instalado, arterial, coletor e local, há possibilidade de readequação dos fluxos de mobilidade. Também foram verificadas as declividades que afetam as vias e a influência que eventos chuvosos de TR 10, 25 e 100 anos teriam nessas porções. Como resultado, o trecho desde a Invernada da Polícia Militar até a rua Meireles Reis (01) tem potencial para a distribuição de fluxos dos dois lados da via, sendo que em um deles estará permeada por áreas verdes. O sistema poderá ser expandido até a rua Voluntários da Pátria, exigindo maiores alterações de tráfego. Outra vantagem é que esta porção do vale é a menos afetada por enchentes, por sua posição a montante do córrego Mandaqui. O segundo trecho identificado (02) está a continuação do primeiro, mas conta com via apenas à esquerda e poderá ser afetada pelas cheias do córrego Água Preta. O terceiro trecho (03) está na porção média do Mandaqui, próximo à rua Zilda, e conta com via somente do lado direito do vale, nos limites externos da Planície Aluvial. Essa área é afetada por chuvas de intensidade a partir de TR 10 anos. 
Figura 71: vias com potencial para receber fluxos de mobilidade da av. Eng. Caetano Álvares e o impacto das enchentes até TR 100 anos nessas áreas.

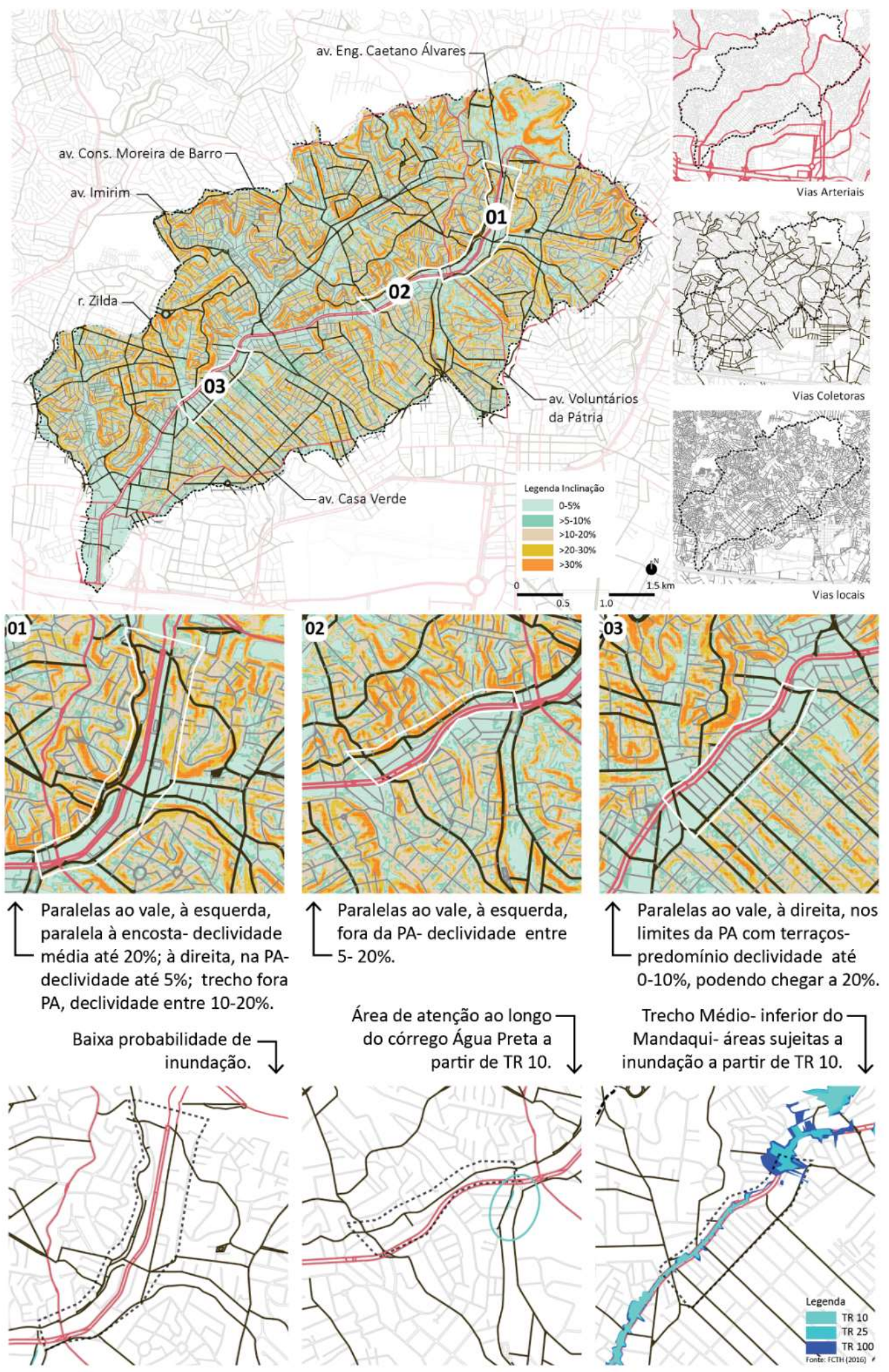

Fonte: elaborado pela autora. 


\subsection{CONECTIVIDADE E ACESSIBILIDADE ÀS ÁREAS VERDES}

Os estudos descritos a seguir tiveram o objetivo diagnóstico, de compreender o papel do eixo do Mandaqui na conexão dos Espaços Abertos da bacia (MARQUES, 2019), além de identificar a população atualmente beneficiada pela proximidade às áreas verdes e a facilidade em acessá-las. O diagnóstico fornece indicações quanto ao potencial catalizador de uma rede verde multifuncional na bacia do Mandaqui, tendo nos eixos selecionados a estrutura inicial para que a rede possa ser expandida, permeando o tecido urbano.

O primeiro estudo avaliou a conectividade na escala da bacia. Selecionou os principais Espaços Abertos relacionados às estruturas lineares localizadas nos vales dos córregos Mandaqui, Lauzane e Tabatinguera, além de destacar conexões diretas ao longo de Topos das Altas Colinas, do Linhão, da Planície Aluvial do Tietê e entre o Mandaqui e a ZEPAM do Parque Niazi Chohfi. Como resultado, o mapa de conexões potenciais indica: (1) Espaços Abertos (verdes, azuis ou cinzas), proeminentes nos fundos dos vales; (2) Polos (conforme identificados na escala do transecto, ver Parte II- Capítulo 1); (3) Pontos com necessidade de ancoragem em polo ou fragmento; (4) Potencial de extensão dos eixos identificados (Figura 69). Outros eixos, além daqueles indicados, poderão ser criados a partir de estratégias da Floresta Urbana e da criação de novos Espaços Abertos que possam funcionar como nós de conexão da rede. Tais alterações somente serão possíveis a partir de estratégias mais extremas que envolvam desapropriações com demolições além da mudança do uso do solo e, portanto, deverão ser averiguadas caso a caso, identificando-se, nas áreas com menor presença de Espaços Abertos, imóveis e terrenos subutilizados.

O segundo estudo se pautou na análise da acessibilidade às áreas verdes de acordo aos seguintes critérios aplicados aos Espaços Abertos:

- Área verde pública classificada como tipo 1, 2 ou 3 (As quatro Naturezas );

- áreas mínimas iguais a 0,5 ha;

- $\quad$ presença de equipamentos de apoio para uso da população;

- acessibilidade gratuita (mesmo que o acesso a estacionamentos possa ser pago) e garantido ao longo do dia (podendo ou não fechar durante algumas horas do dia/ noite). 
Figura 72: Potenciais conexões estruturadoras na bacia do Mandaqui.

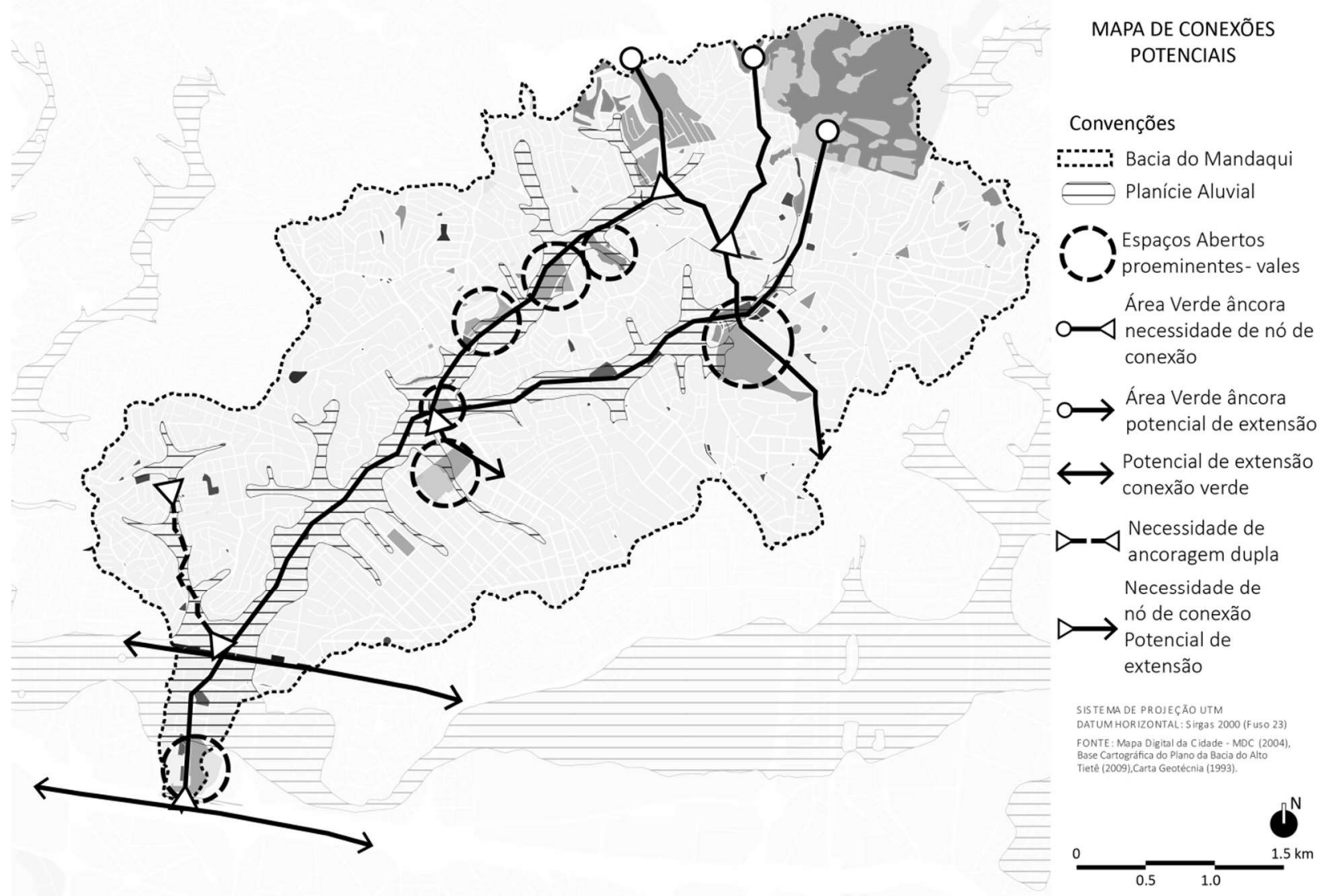

Fonte: MARQUES, T.H.N., (2019).

No caso de áreas verdes de até 5 ha, compostas por praças e pequenos parques, foi verificada a porcentagem acessível à população, mínima de 0,5 ha, para a classificação conforme a tabela de distancias de influência. Outra exceção foi o Horto Florestal. Embora a unidade de conservação tenha 174 ha, apenas cerca de 35 ha são atualmente acessíveis à população, portanto o parque foi classificado na classe de influência $>10 \leq 100$. Quanto às UC com áreas aproximadas ou maiores a 500 ha, o diâmetro completo de influência foi calculado.

A distância de influência de cada parque foi simulada por um buffer, seguindo os indicadores definidos no Subcapítulo 4.3- Parte I. Como resultado, foi possível estimar o número de pessoas atualmente beneficiadas e onde estão localizadas na bacia. Primeiramente foi feito o cruzamento, por SIG, dos dados populacionais fornecidos pelo CENSO (2010) com as áreas residenciais destacadas do MDC (2010). Sequencialmente, os buffers de amplitude dos parques 
foram relacionados aos resultados do primeiro processo, definindo assim, o número estimado de pessoas que possui acesso aos parques. A porção superior do Mandaqui é aquela que concentra a maior quantidade de áreas verdes, tanto ao longo do vale, quanto nas áreas mais altas do relevo, com distintas dimensões. De um total de 37.037 pessoas beneficiadas pela proximidade às áreas verdes de área $0.5 \leq 5$ ha na bacia, (cerca de 11,7\% da população), 11.349 possuem dois parques a no máximo $300 \mathrm{~m}$ de suas casas e 3.084 possuem três parques dessas dimensões próximos a suas residências (Quadro 18). Uma área verde pública de 2,53 ha, e a ZEPAM Niazi Chohfi, foram desconsideradas por não estarem acessíveis à população. Não foram encontrados parques $>5 \leq 10$ ha na bacia ou em áreas de influência. Quanto a dimensão $>10 \leq 100$ ha, não existem na bacia, porém o Mandaqui está na área de influência de três parques, o Horto Florestal (área acessível), o Parque da Juventude e o Parque da Água Branca. No caso do Parque da Água Branca, a área de influência não atinge áreas residenciais da bacia e o fato de estar localizado na margem esquerda do Tietê, poderá dificultar seu acesso. Portanto, considerando-se a influência do Horto e do Parque da Juventude, estimou-se que esses parques sejam acessíveis a cerca de 60.262 pessoas que vivem na bacia do Mandaqui, 19\% da população (Figura 70).

As áreas verdes entre $>100 \leq 500$ ha com influência na bacia são compostas pela Invernada da Polícia Militar, Campo de Marte e Horto Florestal (área completa), porém, atualmente não são acessíveis à população. Quanto às áreas maiores a 500 ha, a bacia do Mandaqui está completamente influenciada pela UC da Serra da Cantareira e parcialmente pela APA Várzeas do rio Tietê (Parque Ecológico do Tietê). O Parque Ecológico é acessível a cerca de 159.670 habitantes da bacia do Mandaqui, aproximadamente $50 \%$ da população. Esse grupo de pessoas também está localizado a distancias acessíveis à Serra da Cantareira (Figura 71). O Quadro 18 apresenta os dados referentes à acessibilidade dos parques descritos acima. 
Quadro 18: Habitantes beneficiados pela acessibilidade às áreas verdes na bacia do Mandaqui.

\begin{tabular}{|c|c|c|c|c|}
\hline Área (ha) & $\begin{array}{l}\text { Habitantes } \\
\text { Beneficiados } \\
\text { na Bacia }\end{array}$ & $\begin{array}{c}\text { Área } \\
\text { Espaço } \\
\text { Aberto } \\
\text { (ha) }\end{array}$ & $\begin{array}{l}\text { Área verde } \\
\left(\mathrm{m}^{2}\right) \times \\
\text { habitante } \\
\text { beneficiado } \\
\text { na bacia* }\end{array}$ & Observações \\
\hline \multirow[t]{2}{*}{$>0.5 \leq 5$} & 37037 & 8.40 & 2.27 & $\begin{array}{c}\text { Canteiro central foi considerado Espaço Aberto } \\
\text { único, embora haja interrupções, ele é utilizado } \\
\text { de forma linear; } 1 \text {. uma praça de área } 1.1 \text { ha } \\
\text { possui grande declividade, reduzindo sua área } \\
\text { acessível para cerca de } 0,5 \text { ha. } 2 \text {. Espaço Aberto } \\
\text { com } 2.53 \text { ha, porém murado e atualmente } \\
\text { inacessível; 3. há também uma área delimitada } \\
\text { como ZEPAM de } 4.27 \text { ha, ainda inacessível à } \\
\text { população. Estas áreas não foram } \\
\text { consideradas. }\end{array}$ \\
\hline & 289 & 8.20 & - & $\begin{array}{l}\text { Espaços Abertos encontrados fora da bacia e } \\
\text { que influenciam os moradores do Mandaqui. }\end{array}$ \\
\hline$>5 \leq 10$ ha & \multicolumn{4}{|c|}{ Não há na bacia ou não está na área de influência. } \\
\hline \multirow{2}{*}{$>10 \leq 100$ ha } & 13.689 & 85.76 & - & $\begin{array}{l}\text { Foram consideradas as áreas de influência do } \\
\text { Parque da Juventude e do Parque da Água } \\
\text { Branca. }\end{array}$ \\
\hline & 46.573 & 35 & - & $\begin{array}{l}\text { Horto Florestal tem área total de } 174 \text { ha e sua } \\
\text { área acessível é } 35 \text { ha, considerou-se o buffer } \\
\text { de influência das áreas de } 20 \text { ha. }\end{array}$ \\
\hline $\begin{array}{c}>100 \leq 500 \\
\text { ha }\end{array}$ & - & - & - & $\begin{array}{l}\text { Invernada da Polícia Militar, Campo de Marte e } \\
\text { o Horto Florestal completo são potenciais áreas } \\
\text { verdes maiores a 100ha. Como atualmente são } \\
\text { inacessíveis ao público geral, não foram } \\
\text { consideradas nos cálculos. }\end{array}$ \\
\hline \multirow{2}{*}{$\begin{array}{l}\quad>500 \text { ha } \\
\text { (Unidades de } \\
\text { Conservação) }\end{array}$} & 159.670 & 1417.1 & - & Parque Ecológico do Tietê \\
\hline & 315.342 & 7916.52 & - & Parque Estadual da Cantareira \\
\hline
\end{tabular}

Fonte: elaborado pela autora. 
Figura 73: Acessibilidade às áreas verdes. Situação atual.

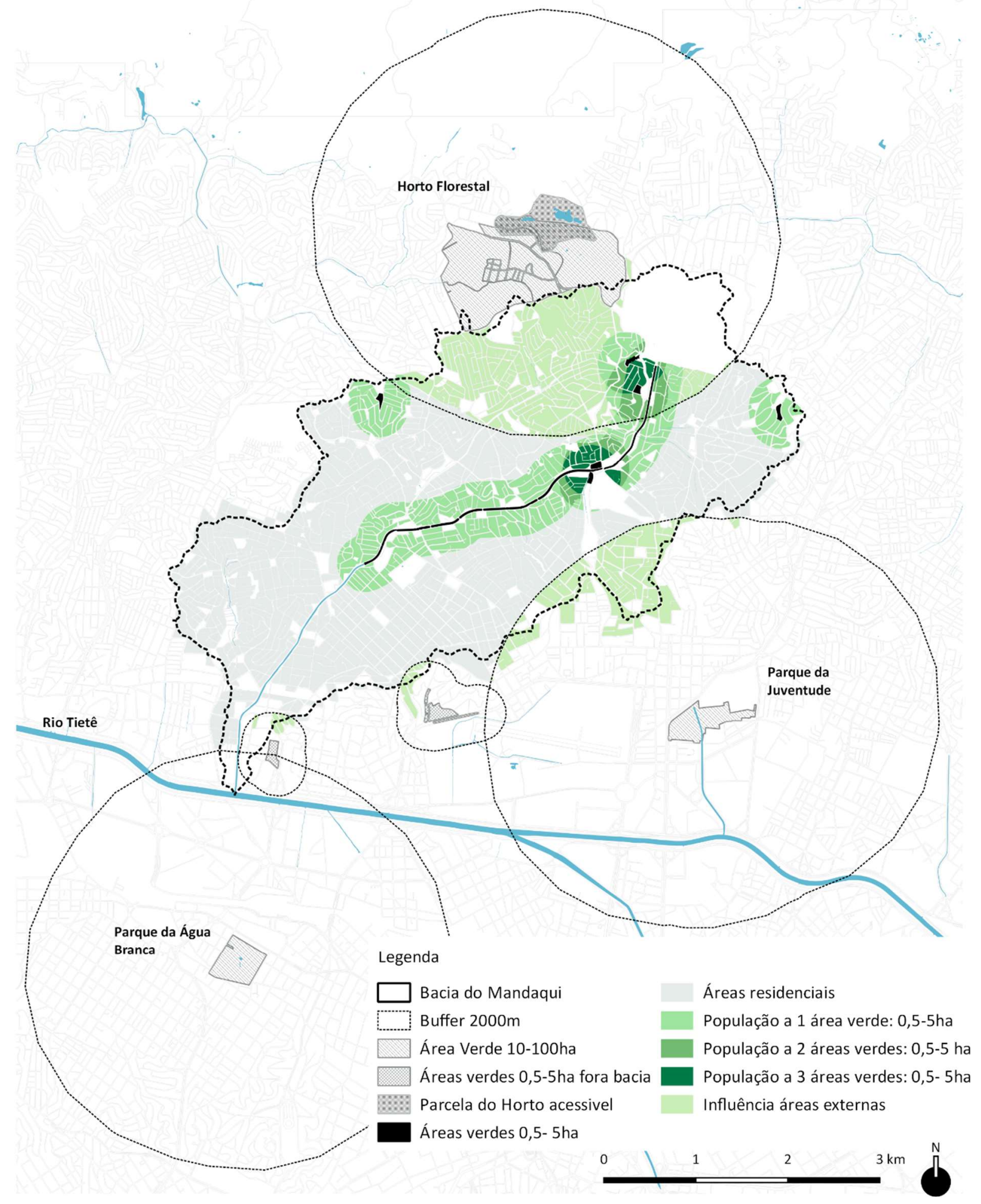

Fonte: elaborado pela autora. 
Figura 74: Área de influência de parques em torno de 500 ha

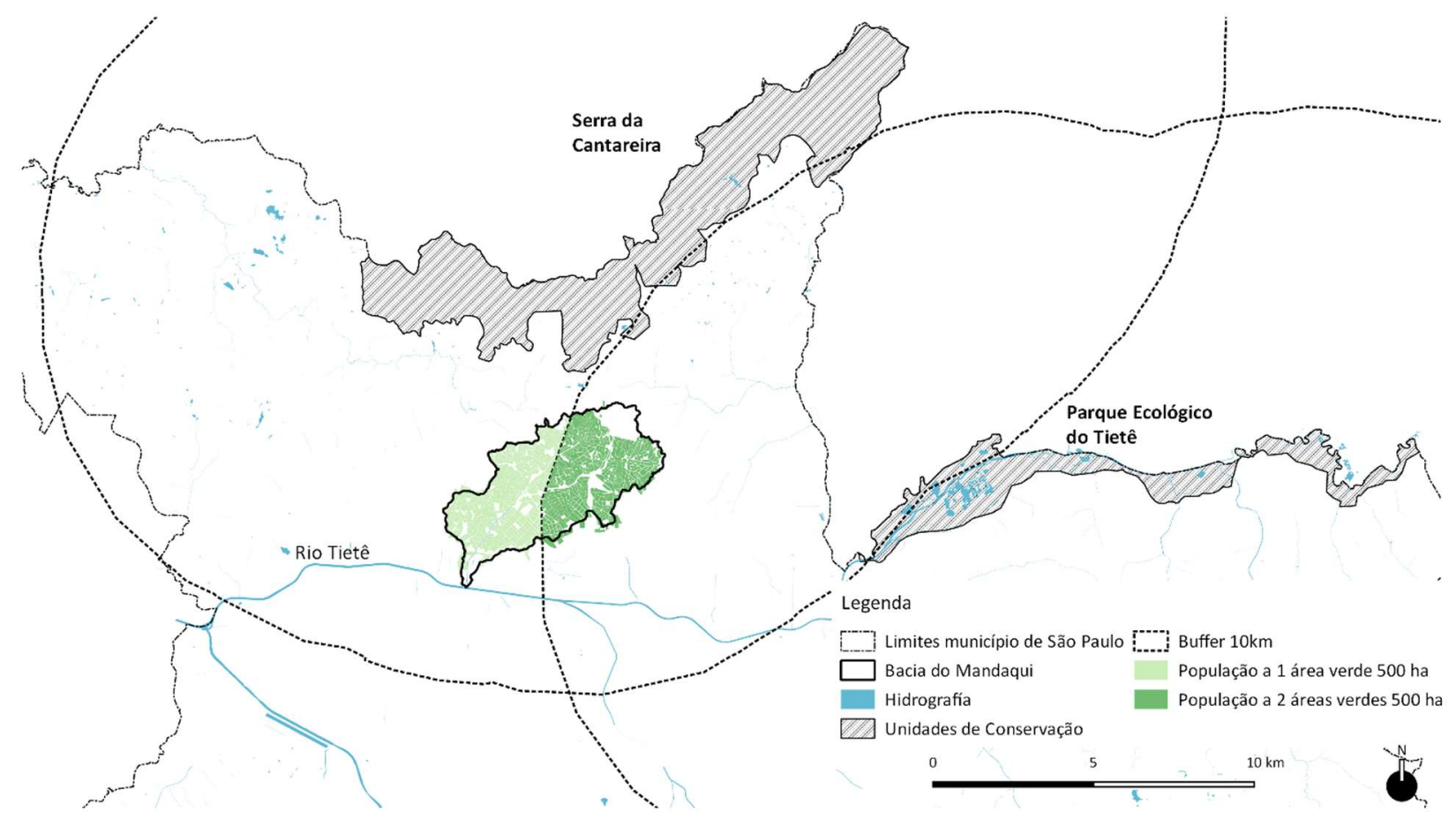

Fonte: elaborado pela autora.

A elaboração da análise de acessibilidade nos forneceu um panorama da oferta e demanda por áreas verdes na bacia do Mandaqui, ficando evidente as áreas com mais facilidade de acesso a elas, na porção superior da bacia. Analisando-se fotografias entre os anos 2010 e 2019, compiladas por imagens do aplicativo google street view e por fotos tiradas pela autora entre 2016 e 2019, é possível notar que a manutenção das áreas verdes públicas é bastante variável, assim como a eventual ocupação de algumas delas por população carente. Estes fatores influenciarão o uso desses espaços, guardando um potencial de acessibilidade atrelado ao estado de conservação das áreas públicas que poderá variar bastante ao longo do tempo.

O papel do canteiro central entre as pistas da avenida Engenheiro Caetano Álvares é de ponto de encontro central da bacia, por sua localização. Esse eixo oferece acessibilidade a pé às pessoas que vivem ao longo de pouco mais de $2 / 3$ da Planície Aluvial e Encostas, porém a qualidade das rotas de acessibilidade pedonal ao eixo varia. Os estudos relacionados à compartimentação da paisagem, identificaram a predominância de terrenos bastante inclinados e ruas sinuosas, aspectos que dificultam a locomoção tanto a pé quanto por outros meios de transporte. A fim de 
fornecer um panorama das tipologias de rotas pedonais que atualmente conectam o eixo do Mandaqui a outras áreas verdes, e que potencialmente poderão ser reforçados como forma de expansão da rede verde, foram verificadas, considerando-se a existência de Espaços Abertos verdes a distâncias estipuladas em no máximo 300m um do outro. As rotas que não possuem áreas verdes necessitarão de uma atenção ainda maior para serem requalificadas e incorporadas à trama de IEV, dependendo da conversão de outros Espaços Abertos ou espaços não abertos a serem convertidos (Figuras 75 e 76). Para a análise foram apuradas as seguintes variáveis:

- Conexão com outras áreas verdes de maior ou menor porte fora do fundo de vale;

- presença de arborização ao longo da via;

- existência de calçada;

- declividade do terreno;

- rota estritamente pedonal.

A maioria das rotas desafiam as declividades das áreas de Encostas das Altas Colinas e algumas são compostas por trechos pedonais de escadarias e rampas (Figuras 72, 73 e 74).

Figura 75, 76 e 77: exemplos de escadarias, ruas íngremes e rampas de acesso ao eixo do Mandaqui.
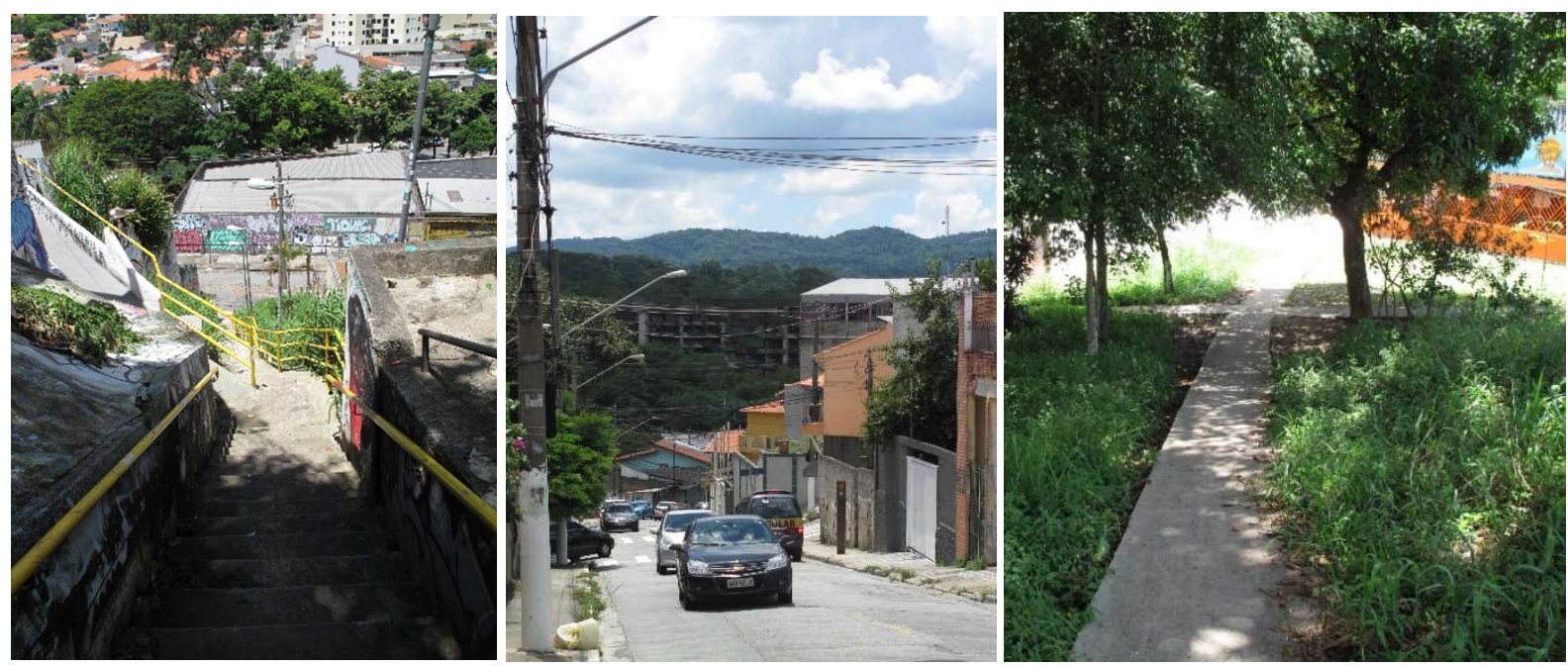

Fonte: autora, 2018 e 2019.

No cruzamento da avenida Imirim, quando a declividade baixa para porcentagens próximas a $5 \%$, se verifica caminhos estritamente para pedestres através de áreas verdes, associados a calçadas sem arborização e de baixa qualidade (MARQUES; BATISTELLA, 2016). Embora ainda sem 
acesso ao público, foram salientadas as áreas da Invernada da Polícia Militar e da ZEPAM do Parque Niazi Chohfi, como oportunidades futuras de acessibilidade à população, a serem exploradas nos Futuros Desejáveis (Parte II- Capítulo 5).

Ao relacionarmos os três estudos apresentados, uma gama de possibilidades poderá ser desenhada para melhorar a quantidade e qualidade das áreas verdes disponíveis, assim como a conexão entre elas, seja na escala da bacia, seja a partir da escala do pedestre, integradas às infraestruturas cinzas quando necessário. Os dispositivos LID e o manejo da Floresta Urbana poderão se guiar em parte por estas análises e serão complementados com o entendimento do impacto das águas e a demanda por áreas de reservação na bacia hidrográfica, apresentados a seguir.

Figuras 78: Acessibilidade ao eixo e conexão áreas verdes até Invernada da PM.

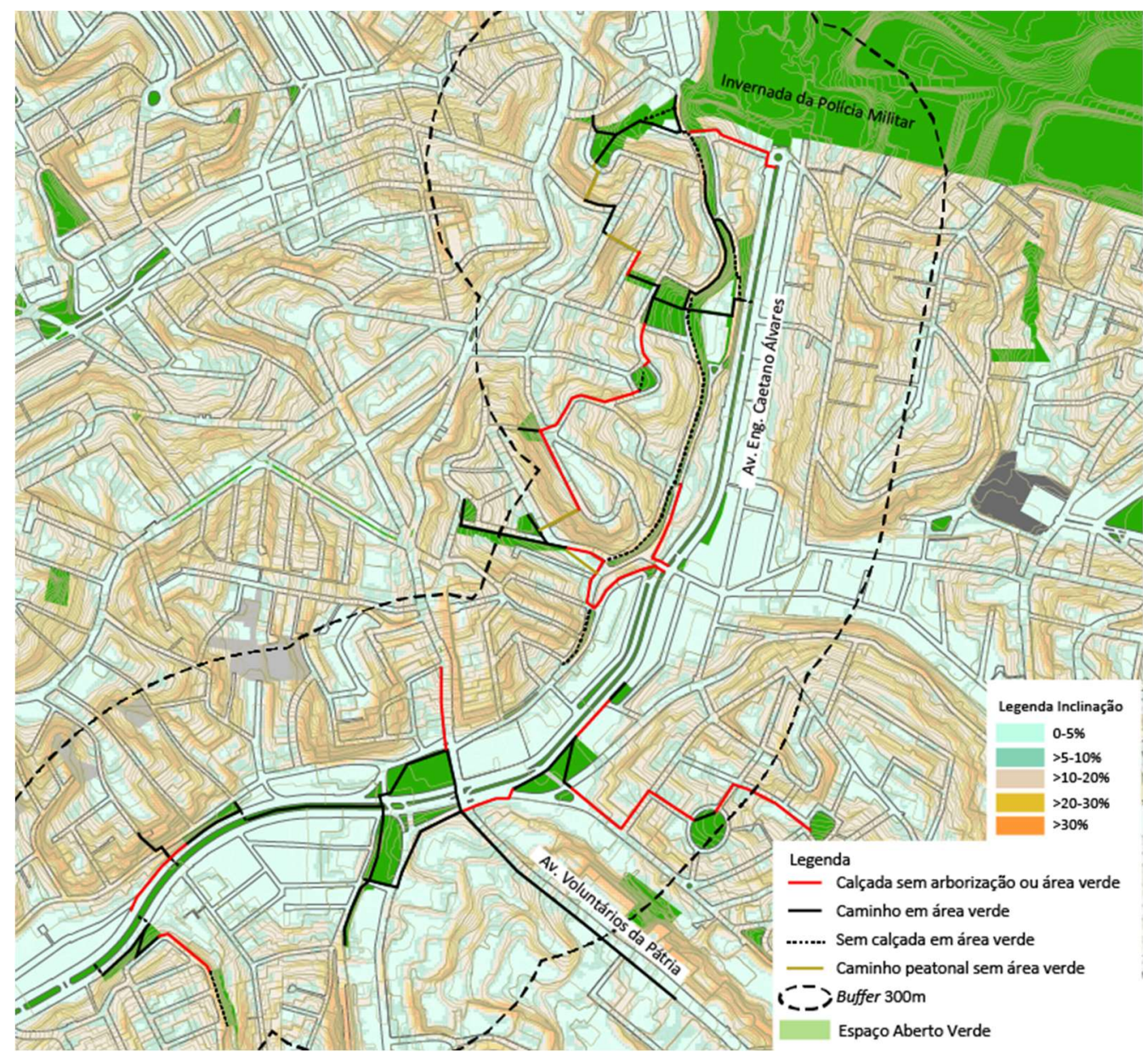

Fonte: elaborado pela autora. 
Figura 79: Acessibilidade ao eixo e conexão áreas verdes até imediações da rua Voluntários da Pátria.

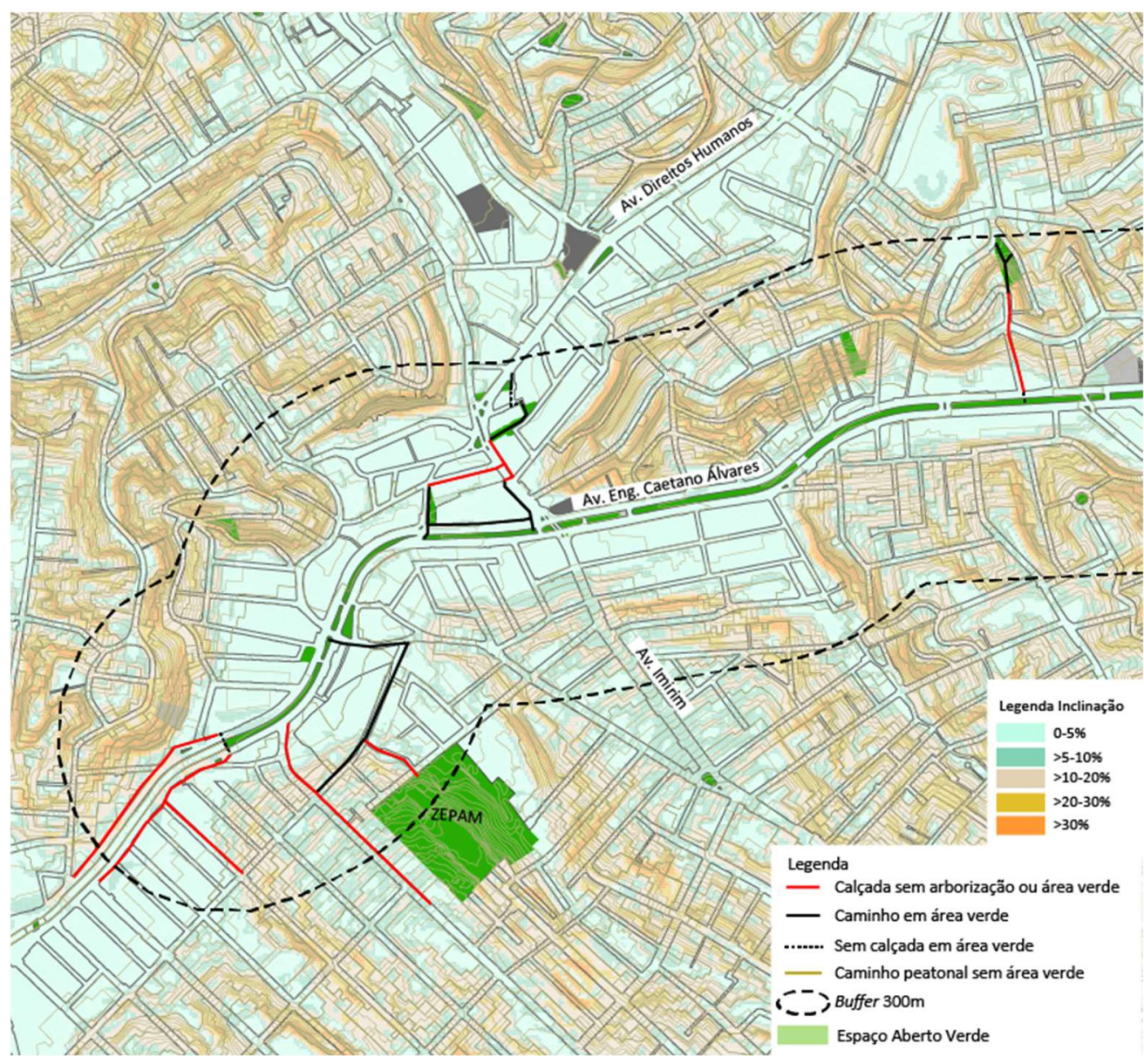

Fonte: elaborado pela autora.

\subsection{IMPACTO DAS ÁGUAS}

A área de impacto das enchentes causadas por eventos extremos, calculados para períodos de retorno de 10, 25 e 100 anos, (SMDU, 2016), foram relacionadas ao número de habitantes diretamente afetados na bacia do Mandaqui. As três manchas de inundação são bastante coincidentes e em grande parte das enchentes está concentrada ao longo da avenida Engenheiro Caetano Álvares e na área de entroncamento com as avenidas Imirim e Direitos Humanos, no encontro das Planícies Aluviais do Mandaqui e Lauzane (Figura 77). No caso mais extremo, TR 100, a população que terá sua casa afetada soma aproximadamente 18.600 pessoas, no entanto, esse conjunto viário é responsável por grande parte das conexões urbanas de 
mobilidade dentro da bacia e entre as bacias vizinhas, o que implica numa população afetada indiretamente muito maior, estimada em pelo menos metade da população da área.

Figura 80: Mapa com as áreas de inundação referentes a chuva TR 100 anos.

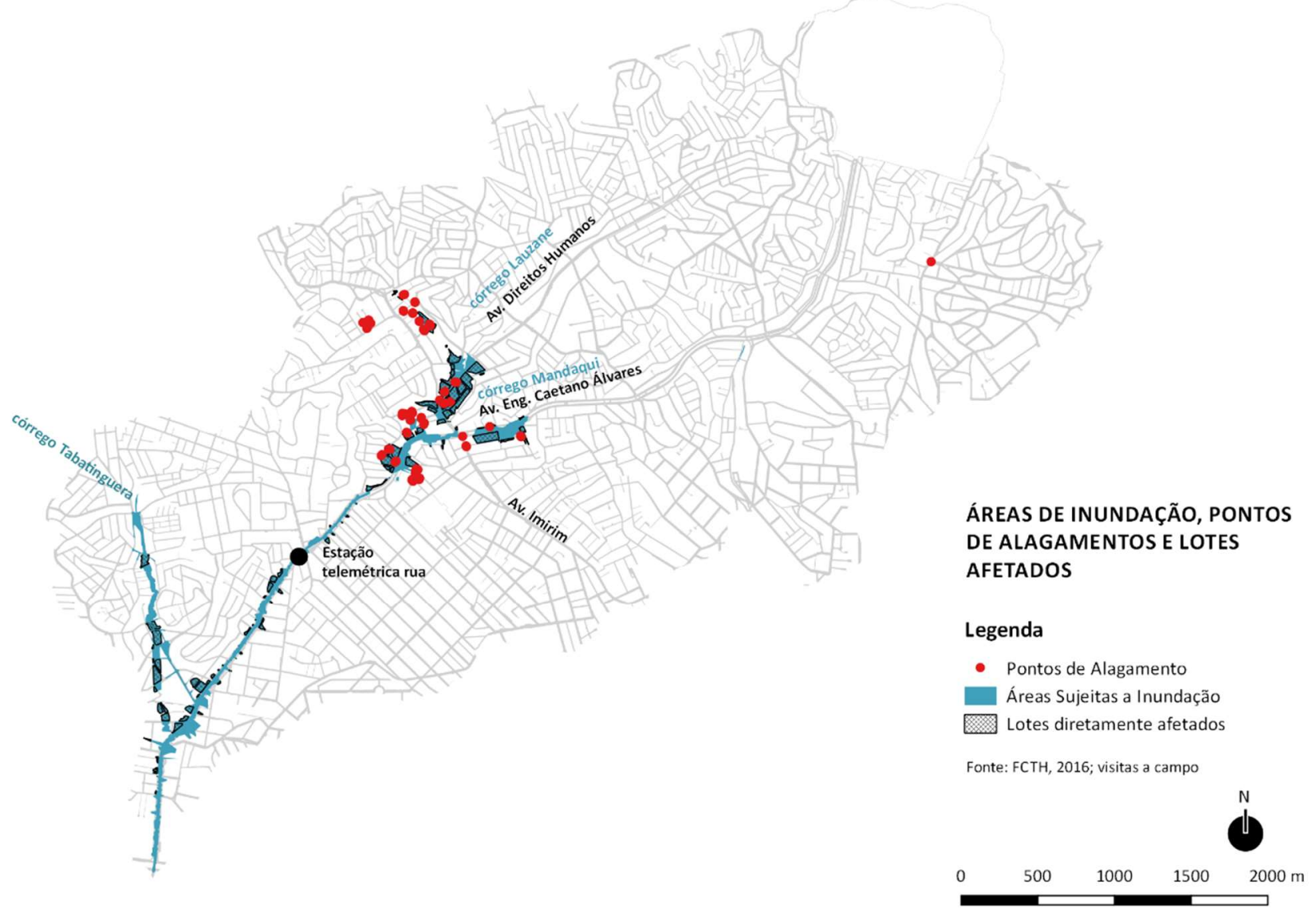

Fonte: elaborado pela autora, a partir de SMDU, (2016) e visitas a campo.

Outro fato constatado a partir da análise dos dados fornecidos pelo Sistema de Alertas a Inundações do Estado de São Paulo (SAISP), foi que o transbordamento do Mandaqui, até a altura da rua Zilda, vem sendo constante pelo menos desde o ano de 2012, quando a estação telemétrica foi instalada nesse ponto do fundo de vale. Desde então, foram registrados 11 episódios de transbordamento do córrego, além de mais de 30 eventos chuvosos que deixaram o canal em estado de atenção (Figura 78). Esse fato fornece uma dimensão distinta àqueles fornecidos pela SMDU, a partir do momento que chuvas muito mais rotineiras àquelas de TR 10, 25 e 100 anos, já vem causando danos às infraestruturas e prejudicando tanto moradores da bacia quanto parte da população que passa pela área em suas atividades diárias. Desenhar a 
Infraestrutura Verde de modo a ser capaz de lidar com as chuvas de rotina deverá estar implícito às diretrizes de projeto de desenho de Eixos Multifuncionais em fundos de vale, além de incluir a dispersão de LID na bacia.

Figura 81: Cota do nível de água no canal do córrego Mandaqui.

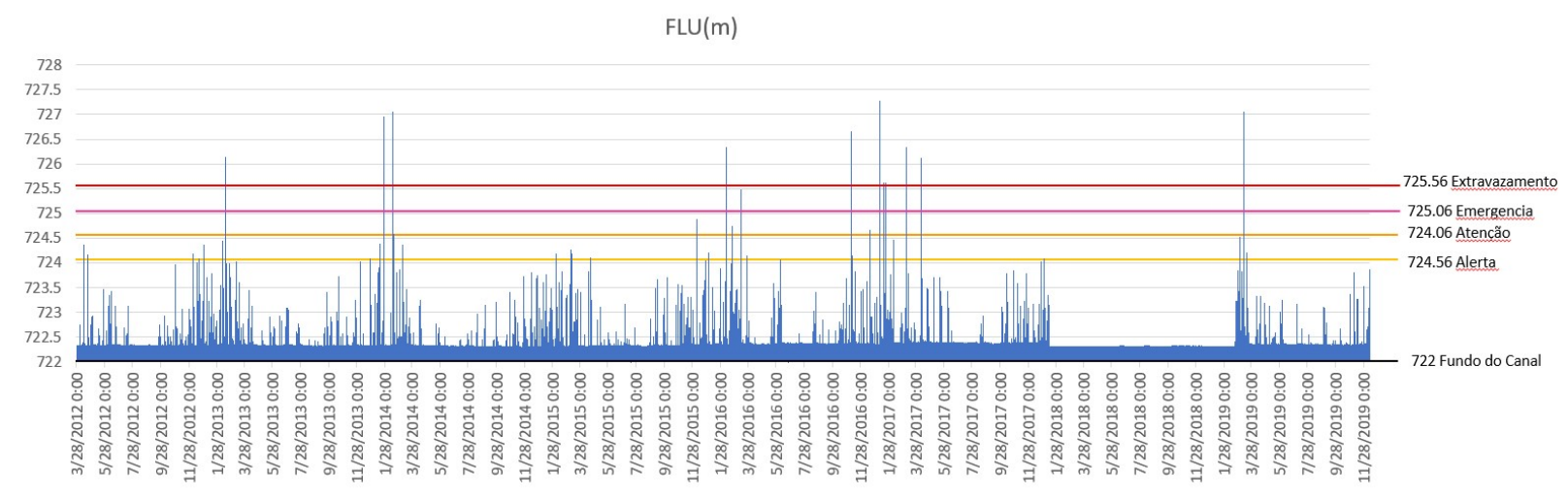

Fonte: elaborado pela autora, a partir dos dados da Estação telemétrica rua Zilda (SAISP, 2019).

A utilização de dispositivos de baixo impacto para controle na fonte, é normalmente dedicada a eventos de menor intensidade, com período de retorno de até 2 anos, quando trabalham de forma eficiente tanto na remoção de cargas poluentes difusas quanto no manejo dos volumes de chuva (FCTH, 2017). A Floresta Urbana também irá contribuir para os menores volumes de chuva. Juntas, estas estratégias podem aumentar a porcentagem de solo permeável e reduzir o escoamento superficial, amortizando o impacto das águas que descem a partir dos compartimentos de Topo e principalmente pelas Encostas das Altas Colinas em direção à Planície Pluvial. Espaços Abertos de maiores dimensões e menores declividades poderão receber reservatórios off-line e os córregos em estado natural poderão ser adaptados por sistemas in-line. O fundo de vale continuará sendo a área receptora dos impactos, por sua condição geomorfológica original, e, portanto, os distintos tipos de reservatórios deverão ser adaptados a estas áreas.

A necessidade de melhora da qualidade da água que chega aos rios e córregos, está relacionada à presença de cargas poluentes pontuais e difusas nas áreas urbanas. Estima-se que a poluição difusa seja responsável por $25 \%$ dos contaminantes presentes nos cursos d'água no país, (TOMAZ, 2007) porém, no Brasil, esse tema ainda não aparece como prioridade em planos 
de ação públicos, os quais se detém a problemas de saneamento considerados mais urgentes, como o manejo dos volumes de água de chuva e a coleta, destinação e tratamento de esgotos. No caso do Mandaqui, o Programa Córrego Limpo (ver Parte II- Subcapitulo 2.1), foi responsável pela remoção de quase todos os lançamentos de esgoto irregulares existentes e monitorados até o ano de 2014. Embora com a descontinuidade do Programa e o crescimento dos assentamentos irregulares, dentre outros fatores, atualmente existem novos pontos de desague irregular, podese assumir que grande parte da contaminação dos córregos seja proveniente de fontes difusas, portanto, a instalação de LID dispersos na bacia será essencial para o abatimento dessas cargas.

\subsection{CONSIDERAÇÕES PARCIAIS: ESPAÇOS ABERTOS E LID}

Nos Capítulos 3 e 4 a paisagem da bacia do Mandaqui foi analisada tanto quanto aos seus potenciais, quanto às suas demandas por áreas verdes acessíveis e capazes de fornecer distintos SE. A Compartimentação da Paisagem relacionou o relevo, as estruturas superficiais e a ocupação do solo quanto aos impactos sobre os processos de regularão hídrica na escala da bacia e fundo de vale. Os LID foram relacionados a cada um dos Compartimentos definidos e tiveram a aptidão para fornecer distintos SE analisada em base a pesquisa bibliográfica. Os distintos Espaços Abertos foram identificados e caracterizados quanto à sua origem ecológica (ou função urbana), posicionados sobre os distintos Compartimentos da Paisagem e relacionados à aptidão em fornecer Serviços Ecossistêmicos. Também verificamos as possibilidades e necessidades de eixos estruturantes da Infraestrutura Verde e pudemos visualizar as manchas de impacto das inundações de distintas intensidades nos fundos de vale. Como forma de compreender o quão acessível às pessoas são atualmente as áreas verdes da bacia, e os SE fornecidos por estas, foi elaborado o estudo de acessibilidade a partir do qual pudemos identificar a grande demanda existente, principalmente quanto às áreas verdes em distancias caminháveis de $300 \mathrm{~m}$ a partir das residências.

Como síntese desse processo analítico, apresentamos um mapa com a espacialização das áreas com demanda por áreas verdes de pelo menos 0,5 ha acessíveis a pé (300 m), o conjunto formado por Espaços Abertos contínuos sem viário, (áreas verdes associadas ao viário e aos córregos, linhão, praças, terrenos baldios e estacionamentos), os Espaços Abertos descontínuos, 
as ZEPAM (Invernada da Polícia Militar e Niazi Chohfi), o Horto Florestal (área não acessível) e o Campo de Marte. Estes últimos dois parques juntamente à Invernada da Polícia Militar, se localizam nos extremos ou áreas externas próximas à bacia, e uma vez acessíveis às pessoas poderão ter grande impacto na qualidade de vida e bem-estar. Alguns espaços descontínuos, formados por grandes estacionamentos de empreendimentos habitacionais, por exemplo, possuem potencial múltiplo, tanto de lidar com as águas de chuva, infiltrando e conduzindo os volumes ao longo dos Terraços e Encostas das Altas Colinas, quanto fornecendo áreas de lazer para os moradores. O mapa irá fornecer subsídios para que Futuros Desejáveis possam ser discutidos a seguir.

Figura 82: Mapa de demandas por áreas verdes de área mínima 0,5 ha, impacto das inundações e Espaços Abertos da bacia.

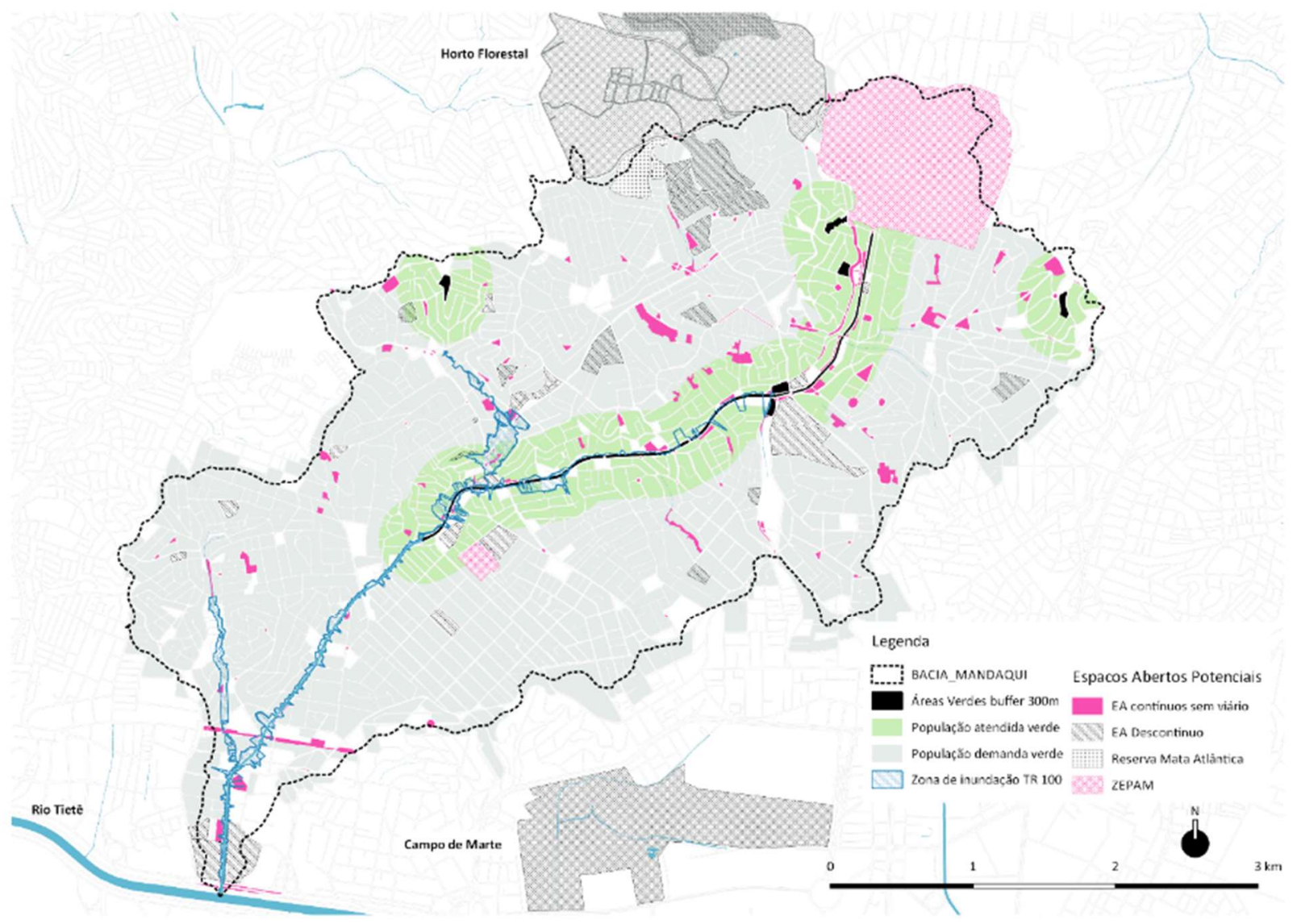

Fonte: elaborado pela autora. 


\section{CENÁRIOS POSSÍVEIS E FUTUROS DESEJÁVEIS}

Como visto durante os capítulos anteriores, as paisagens são resultado de um conjunto de dinâmicas que envolvem distintos processos espacial e temporalmente associados. Compreender a existência de processos e do agente tempo, nos coloca em uma posição projetual e de planejamento que considera pensarmos lugares possíveis, sem a certeza futura. Não é possível saber com exatidão o que acontecerá no futuro, real, mas sim, é possível tentar compreender em largo prazo, o que acontecerá e quais são as probabilidades futuras.

Os cenários são amplamente utilizados como estratégia de enfrentamento as estas incertezas, tanto para o planejamento a longo prazo, quanto para a toma de decisões a curto prazo que, no entanto, terão consequências futuras (MAHMOUND et al., 2009). São considerados esboços para um futuro hipotético (STEINITZ, 2012), representações de possíveis futuros, sem a pretensão de predizer o que acontecerá, mas sim expor inquietações e buscar respostas para um conjunto de perguntas (AHERN, 1999), fornecendo uma visão dinâmica de futuro e distintos caminhos para alcançá-lo (MAHMOUND et al., 2009).

A utilização de cenários fornecerá aos tomadores de decisão, perspectivas que desafiam o pensamento convencional ao buscar estes futuros possíveis (HIRSCHORN, 1980; MAHMOUND et al., 2009), demonstrando uma gama de alternativas para que então um caminho possa ser escolhido a partir da comparação dessas possibilidades entre si (STEINITZ, 2012), utilizando-se critérios pré-definidos (CRESWELL, 2009).

Os cenários podem ser definidos por distintas metodologias. Hirschorn (1980) indica que, em planejamento, poderão ser do tipo "Estado", os quais somente apresentam como a área de estudo será no futuro, ou do tipo "Processo", os quais incluem a necessidade de estabelecer uma guia de ação (tradução nossa para Roadmap), que considere suposições, eventos e etapas relacionando a situação futura à atual, ou seja, demonstra como chegar ao futuro mencionado. Por seu aporte adaptável ao longo do tempo, o cenário do tipo "Processo" é o mais adequado ao planejamento da paisagem e deverá incluir a descrição da situação atual, o potencial estado futuro e um modo de implementação (NASSAUER; CORRY, 2004; AHERN, 1999).

Para o planejamento da paisagem a representação dos cenários deverá contemplar necessariamente as alterações do uso do solo e suas consequências espaciais, preferencialmente 
representadas por mapas e outros artifícios visuais em detrimento a serem baseados apenas em cálculos quantitativos (NASSAUER; CORRY, 2004). Nassauer e Cory (2004) propõem a utilização de cenários normativos, ou seja, a transformação dos cenários possíveis em futuros desejáveis, baseados em distintas hipóteses. Stremke (2010), segue uma metodologia parecida ao propor o desenho de paisagens energeticamente sustentáveis a partir de um método que considera em seus passos o desenho de uma matriz de quatro cenários, representados em mapas e textos de referência, que são posteriormente adaptados a quatro visões de futuros desejáveis baseadas nos fatores de impacto identificados para cada um dos cenários. Esse processo tende a reforçar aspectos positivos de cada situação simulada e pretende estimular a toma de decisão (NASSAUER; CORRY, 2004).

Os cenários podem variar de acordo com inúmeros agentes de mudança (STEINER, 2002) e terem distintos espectros temporais. Na tese um período de 24 anos foi considerado, 20202044, abrangendo três revisões dos Planos Municipais, 2024, 2034 e 2044 respectivamente. Os três cenários: (1) O Mínimo para o Máximo; (2) Mantendo os Pés Secos; e (3) Reconquista da Várzea, foram definidos a partir dos seguintes agentes:

- Crescimento populacional

- Crescimento Econômico

- Aplicação de normativas presentes em Planos e Programas

- Participação da população

Um texto explicativo descreve cada cenário, seguido de uma proposta para Futuros Desejáveis. Para cada uma das situações, os seis princípios de IEVu são acessados, assim como os critérios extraídos das etapas da pesquisa apresentadas anteriormente, conforme segue:

- Alterações no uso e ocupação de solo

- Quantidade, qualidade e acessibilidade às áreas verdes

- Utilização de técnicas LID para a drenagem urbana

- Integração da Infraestrutura Verde no Eixo Multifuncional 
Finalmente, os Futuros Desejáveis serão discutidos a fim de responder à seguinte pergunta:

Como é possível enfatizar as sinergias e reduzir os trade-offs e desserviços entre as infraestruturas no fundo de vale para a transição a Eixo Multifuncional?

\subsection{CENÁRIO E FUTURO 1: O MÍNIMO PARA O MÁXIMO}

Este cenário considera as tendências atuais de decrescimento populacional, um crescimento econômico moderado, a aplicabilidade parcial das diretrizes dispostas nos Planos e Programas com impacto na bacia e uma intensa atividade cidadã. A redução da população residente na área gera uma maior quantidade de edifícios vazios e lotes subutilizados, motivando estratégias de baixo custo para a requalificação das áreas urbanas, assentamento de população carente e a potencialização de atividades de lazer e recreação nas áreas da bacia do Mandaqui.

Grupos preocupados com a melhoria da qualidade de vida urbana se organizam para efetivar ações tais como plantio arbóreo, ativação do espaço público, requalificação e instalação de hortas urbanas, jardins de chuva e biovaletas ao longo das vias, em áreas verdes associadas ao viário, praças e lotes subutilizados. Áreas verdes públicas passam a ser acessíveis. Na escala do lote, a população instala cisternas conectadas a sistemas de utilização das águas de chuva, motivados por períodos de seca alternados àqueles de chuvas intensas. O trecho da avenida $\mathrm{Eng}^{\circ}$. Caetano Álvares acima da rua Mariquinha Viana até a Invernada da PM passa a fechar aos domingos e feriados para atividades de lazer, o mesmo ocorre em outras vias locais da bacia (ex.: adesão ao Programa Rua Aberta ${ }^{66}$ ). Os investimentos públicos, municipais com aporte estadual, focam na instalação da proposta da Alternativa 2 apresentada no Caderno de Bacia Hidrográfica (SMDU, 2016), para o manejo dos grandes volumes de águas, motivados principalmente pelos danos causados pelas chuvas da década de 2010. As urbanizações das favelas do córrego Tabatinguera são associadas àquelas de macrodrenagem. A demanda por Espaços Abertos motiva o poder público a alterar o desenho dos reservatórios, adaptando os modelos abertos para dispositivos

\footnotetext{
${ }^{66}$ O Programa Rua Aberta é uma iniciativa da Prefeitura Municipal de São Paulo e visa o fechamento completo ou parcial de vias durante períodos do final de semana e feriados para uso exclusivo das pessoas. A adesão ao Programa pode partir de iniciativas da População. No Mandaqui, um trecho da rua Gabriel Covelli está incluída no Programa.
} 
fechados, sobre os quais são instalados parques recreativos parcialmente integrados por áreas verdes aos afluentes dos córregos Lauzane e Tabatinguera. Essas áreas passam a ser conectadas ao Eixo do Mandaqui por caminhos pedonais e ciclovias através de áreas verdes e passeios arborizados, além da instalação de novos cruzamentos ao eixo central da avenida, dispostos a partir das iniciativas cidadãs. O córrego Mandaqui segue parcialmente fechado e aberto. No tramo aberto há o rebaixamento do fundo do canal e remoção das estroncas, ação que ao mesmo tempo mostra e afasta o córrego visualmente. A integração verde-cinza nessa área é priorizada ao longo das calçadas da avenida, pela arborização e a partir da conversão de grandes estacionamentos em praças híbridas, parcialmente desenhadas com pisos permeáveis para manter, em parte, a função de estacionamento e em parte convertida em espaços verdes públicos para a população. O Programa Córrego Limpo segue atuando na bacia e promove um trabalho efetivo de conscientização das pessoas em relação à disposição de resíduos sólidos. 0 decrescimento populacional faz com que os assentamentos irregulares sejam estabilizados e dois deles urbanizados mantendo a condição das águas com DBO dentro dos níveis recomendados pelo CONAMA (Figuras 80 e 81).

Aplicação dos princípios de IEVu:

- Multifuncionalidade: as sinergias entre as distintas infraestruturas no fundo de vale e o fornecimento de múltiplos SE pelos Espaços Abertos serão enfatizados por estratégias estruturais e não estruturais. Dentre as estruturais, a instalação de LIDs em áreas verdes associadas ao viário, praças e terrenos subutilizados irá requalificar espaços públicos para atividades de lazer, funcionar como barreira de segurança entre o fluxo veicular e o pedonal e ciclável, além de contribuir com a valorização dos aspectos estéticos da paisagem. Os reservatórios de drenagem inicialmente abertos serão fechados e sobre eles praças esportivas serão instaladas evitando os trade-offs causados pela ociosidade dos piscinões quando não ocupados pelas águas das chuvas. A falta de integração ao longo do canal aberto é parcialmente mitigada por ações nas áreas das quadras lindeiras, que fornecem à população parte da experiencia quanto às dinâmicas das águas em áreas de várzeas. Quanto às medidas não estruturais, por exemplo, hortas são instaladas nas áreas do linhão, gerando sinergias entre a ocupação do solo pelas infraestruturas elétrica e a 
provisão de alimentos além de atender demandas culturais por áreas de sociabilização. Outro exemplo é o fechamento de parte da avenida Engenheiro Caetano Álvares aos domingos e feriados para atividades de lazer e recreação. A alternância de uso do espaço público da avenida, não confere uma sinergia entre os distintos tipos de mobilidade e atividades culturais, uma vez que para uma ocorrer, a outra não ocorre. No entanto a alternância de uso desse espaço é uma estratégia de ativação dessas áreas em horários que estariam ociosas e poderá trazer benefícios à saúde e qualidade de vida, adotando um modelo de multifuncionalidade dinâmico.

- Conectividade: haverá uma tendência de melhora da conectividade das áreas verdes devido ao plantio arbóreo e instalação de LIDs pela população. Devido à organicidade das ações, esse princípio será alcançado em parcelas específicas da bacia.

- Múltiplas escalas: a escala do lote e do sítio específico é priorizada pelas ações cidadãs; áreas dos eixos do Mandaqui, Lauzane e Tabatinguera são os principais alvos das estratégias de intervenção do poder público.

- Importância do contexto: muitas ações implementadas terão caráter local e específicas, uma vez que partem de ações cidadãs. Respeitarão as indicações dispostas no mapa de Compartimentação da Paisagem para a instalação de LIDs nos distintos Espaços Abertos da bacia; a instalação dos piscinões fechados passa a atender uma demanda local por mais espaços de lazer e recreação.

- Integração verde-cinza: a desconexão de calhas e instalação de cisternas em lotes de pequeno porte será motivada tanto pelas enchentes quanto pela necessidade de armazenamento para utilização das águas em épocas de seca. Haverá a instalação de jardins de chuva e biovaletas ao longo das vias, áreas verdes associadas ao viário, praças e lotes subutilizados sem que estejam conectadas ao sistema tradicional de drenagem.

- Processo transdisciplinar: os movimentos cidadãos agirão de modo independente a outros atores e órgãos públicos. O poder público irá focar seus recursos na instalação de estratégias de macrodrenagem atendendo a uma demanda da população por espaços abertos. 
Figura 83: Futuro Desejável- O Mínimo para o Máximo

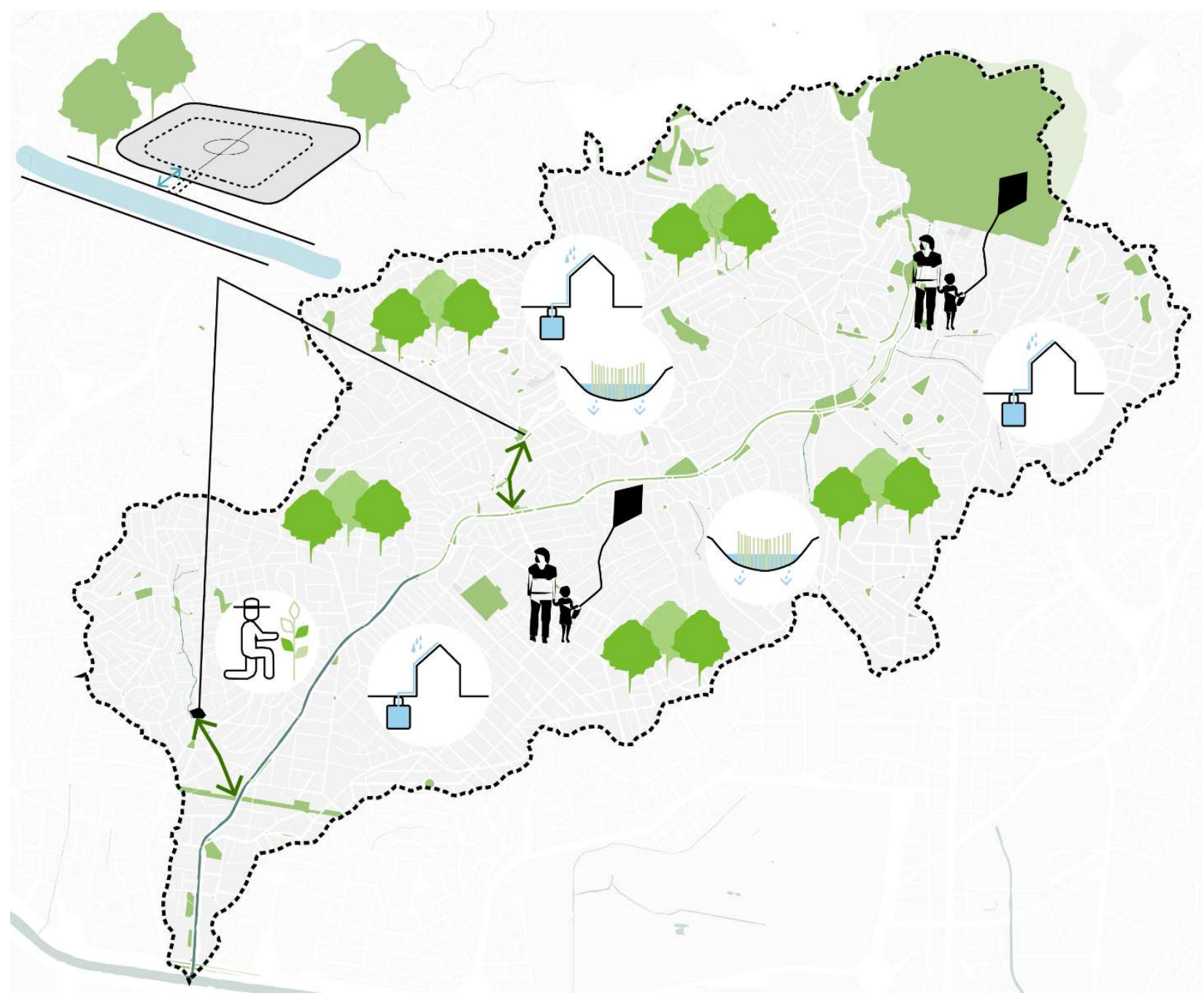

Fonte: elaborado pela autora.

Acesso aos critérios:

- Alterações no uso e ocupação de solo: Manutenção dos usos e ocupação de solo da bacia, com aumento de edifícios desocupados e incorporados às ZEIS.

- Quantidade, qualidade e acessibilidade às áreas verdes: Uma área verde é aberta ao público (tipo 3); há aumento da arborização ao longo das vias e instalação de LIDs dispersos como resultado da ação de movimentos e organizações sociais. Os piscinões embora fechados de concreto, contam com áreas verdes e associam-se aos córregos dos quais recebem as vazões de reservação. 
- Utilização de técnicas LID: LIDs de microdrenagem são espraiados em alguns pontos da bacia. Há uma ligeira alteração da proporção de área ocupada pelas Infraestruturas Verde, de drenagem e mobilidade no fundo de vale do Mandaqui. O trecho do canal aberto é adaptado de acordo com as indicações do PDMAT3, distanciando ainda mais o córrego, visualmente. Os piscinões construídos estão localizados ao longo da avenida Direitos Humanos e do córrego Tabatinguera e serão tampados e ocupados como praças de recreação.

Figura 84: Visualização- Futuro Desejável- O Mínimo para o Máximo

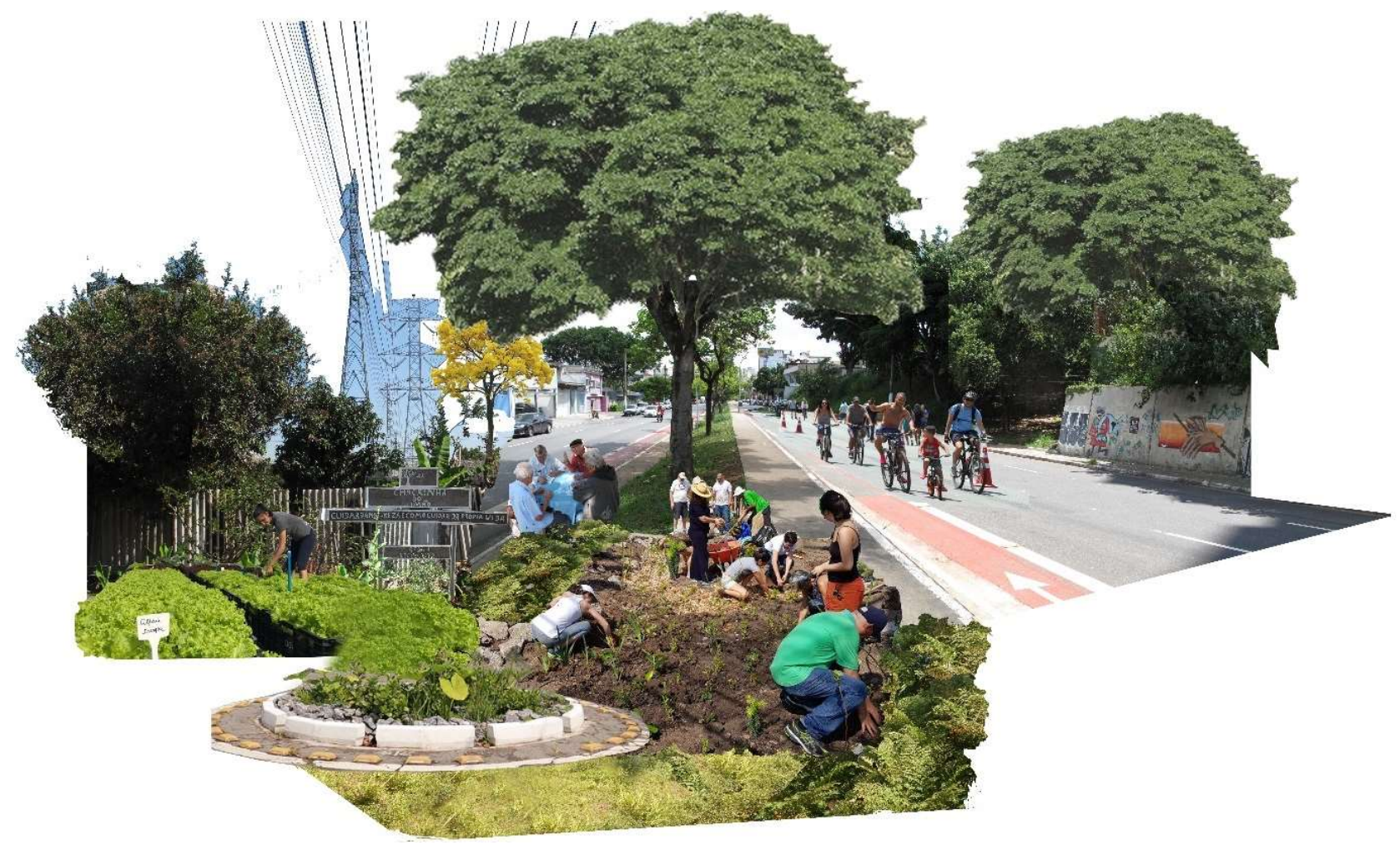

Fonte: elaborado pela autora.

\subsection{CENÁRIO E FUTURO 2: MANTENDO OS PÉS SECOS}

O crescimento econômico impulsiona o mercado imobiliário na região, estimulado por um aumento do interesse em morar na área, o que resulta em um crescimento populacional acumulado de $12 \%$ até 2044. A ampla aplicação dos Planos e Programas de impacto na bacia conta com limitados processos participativos e o papel incisivo dos governos local e estadual na 
tomada de decisões, fazendo com que tanto a porção a jusante quanto a montante do Mandaqui mude completamente.

A jusante o fundo de vale é influenciado pela construção do Apoio Norte, sobre as áreas do linhão enterrado. Altos edifícios de uso misto passam a dominar a paisagem nesta área, mesclados à instalação de um maciço arbóreo acompanhado de ciclovias e faixas pedonais ao longo da avenida. Todos os edifícios contam com área de reservação das águas. A mobilidade também é impactada pela construção do novo terminal de ônibus na esquina da rua Voluntários da Pátria com a avenida Engenheiro Caetano Álvares e um corredor de ônibus é instalado ao longo de toda avenida. A instalação do terminal motiva o desenvolvimento de distintos comércios ao redor desse equipamento, alterando a dinâmica do trecho superior do Mandaqui. Os piscinões propostos pelo Caderno da bacia do Mandaqui são instalados mesclando as Alternativas 1 e 2 (SMDU, 2016), em cada um dos três córregos principais da bacia, incluindo o parque linear em afluente do Lauzane. Os piscinões são propostos em formato fechado, sendo os do Tabatinguera e Lauzane dedicados a áreas de lazer e o do Mandaqui ocupado por edifício de equipamento público sobre praça seca. As estroncas são removidas do trecho aberto do canal. O Parque linear passa a ser utilizado pela população para distintas atividades de lazer e como rota alternativa à avenida Imirim, por formas de mobilidade ativa. Seu impacto aumenta o valor dos imóveis, causando uma gentrificação verde ${ }^{67}$, e parte da população deixa a área ao longo dos anos, abrindo espaço para que novos empreendimentos imobiliários ocorram na região. As favelas contempladas pelo plano de ZEIS do PDE 2014 são plenamente urbanizadas, mas outros focos de ocupação irregular surgem na bacia. O Programa Córrego Limpo segue ativo a fim de evitar a contaminação das águas da bacia por esgotos domésticos. Ao longo do Tabatinguera o córrego é canalizado por estruturas de gabiões e recebe ciclovias e passeios públicos, permitindo o desenvolvimento de fauna ciliar passível de contribuir para a melhora da qualidade da água. Há a integração de estratégias do governo estadual e municipal para a conversão de áreas ZEPAM

\footnotetext{
${ }^{67}$ Os processos de gentrificação são associados a propostas de requalificação urbana que por consequência, aumentam o preço dos imóveis e terrenos, fazendo com que populações que viviam no local não consigam mais arcar com os custos de vida nessas áreas. Quando associada à valoração da terra urbana pela presença de áreas verdes, podemos chamar esse processo de Gentrificação Verde, ou seja, zonas com mais áreas verdes se tornam mais exclusivas.
} 
em parques acessíveis à população. Quanto aos LIDs de microdrenagem, são instalados sobretudo nas áreas verdes associadas ao viário. A quota ambiental é ampliada a todos os tamanhos de edificações novas ou reformas e passa a sugerir uma lei de incentivos fiscais ao proprietário que adotar técnicas de reservação das águas da chuva. A arborização é feita ao longo das vias requalificadas, por exemplo, avenida Voluntários da Pátria e rua Zilda, sem que haja uma proposta de manejo em longo prazo (Figura 82 e 83).

Aplicação dos princípios da IEVu:

- Multifuncionalidade: sinergias podem ser verificadas principalmente ao longo do Parque Linear Lauzane, a partir do desenho de estratégias para a detenção in-line que também colaboram para o fornecimento de outros SE de regulação, culturais e de suporte à mobilidade ativa. O eixo do Mandaqui se torna mais saturado nas porções superior e inferior devido às grandes obras e equipamentos instalados, afetando o uso do canteiro central devido ao aumento de ruído e contaminação atmosférica (desserviços). Por outro lado, as calçadas são requalificadas e arborizadas, favorecendo a mobilidade a pé ao longo do eixo. Quanto às águas do Mandaqui, permanecerão confinadas em galerias de concreto subterrâneas nos trechos superior e médio e em canal aberto no trecho inferior.

- Conectividade: algumas vias da bacia são arborizadas e recebem LID, iniciando a formação de uma rede de IEV. A conexão entre as áreas verdes é favorecida pela abertura das ZEPAM, intencionalmente conectadas ao eixo do Mandaqui, para uso público.

- Múltiplas escalas: intervenções ao longo de vias de mobilidade são enfatizadas, assim como a instalação do novo terminal, piscinões- praça e Parque Linear, alterando a dinâmica de toda a bacia. Na escala do lote, a instalação de reservatórios é incentivada pelas políticas públicas.

- Importância do contexto: o Apoio Norte atende a demandas de contextos metropolitanos quanto à mobilidade, sem que haja processo participativo para sua instalação, causando grande impacto social na área. As alterações viárias, seguindo os perímetros de ação dos PRE, seguem anseios da população, mas no geral, replicam alternativas genéricas. Quanto ao contexto geomorfológico, é considerado parcialmente. 
- Integração verde-cinza: as infraestruturas são instaladas em sequência, por exemplo, o Parque Linear do Lauzane se posiciona anteriormente ao reservatório de água da avenida Direitos Humanos. Os LID de controle in-situ são conectados aos sistemas tradicionais de drenagem

- Processo transdisciplinar: limitado.

Figura 85: Futuro Desejável- Mantendo os Pés Secos.

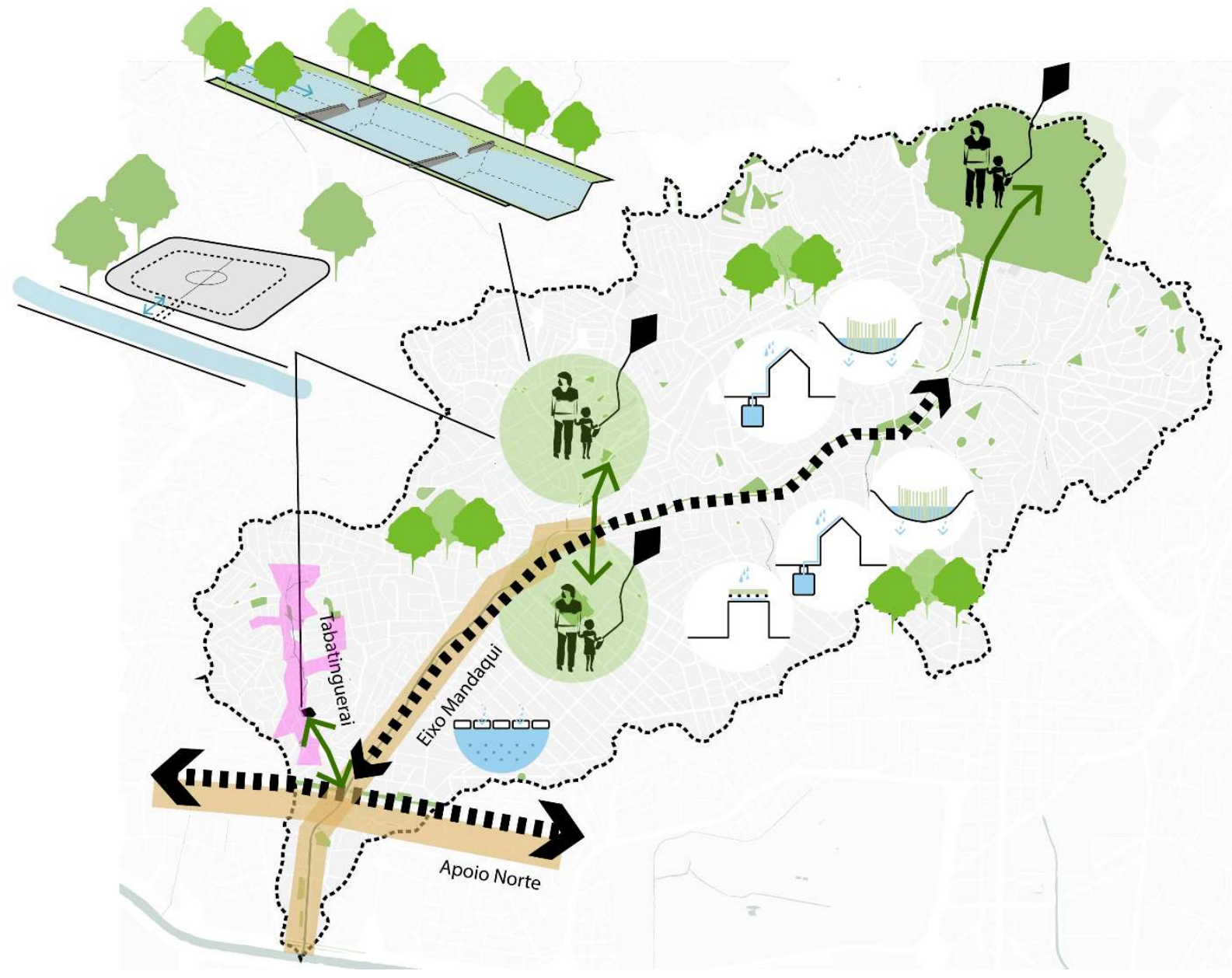

Fonte: elaborado pela autora.

Acesso aos critérios:

- Alterações no uso e ocupação de solo: verticalização intensiva nas áreas de influência do Apoio Norte e em setores dos distritos do Mandaqui e Santana. Ao 
longo do Mandaqui tem início um processo de verticalização para usos mistos do solo.

- Quantidade, qualidade e acessibilidade às áreas verdes: As áreas verdes acessíveis aumentam com a adição do Parque linear, das duas áreas de ZEPAM e da praça de área entre $0,5 \leq 5$ ha.

- Utilização de técnicas LID: limitada quanto à microdrenagem e evidente ao longo do Parque Lauzane.

Figura 86: Visualização- Futuro Desejável- Mantendo os Pés Secos

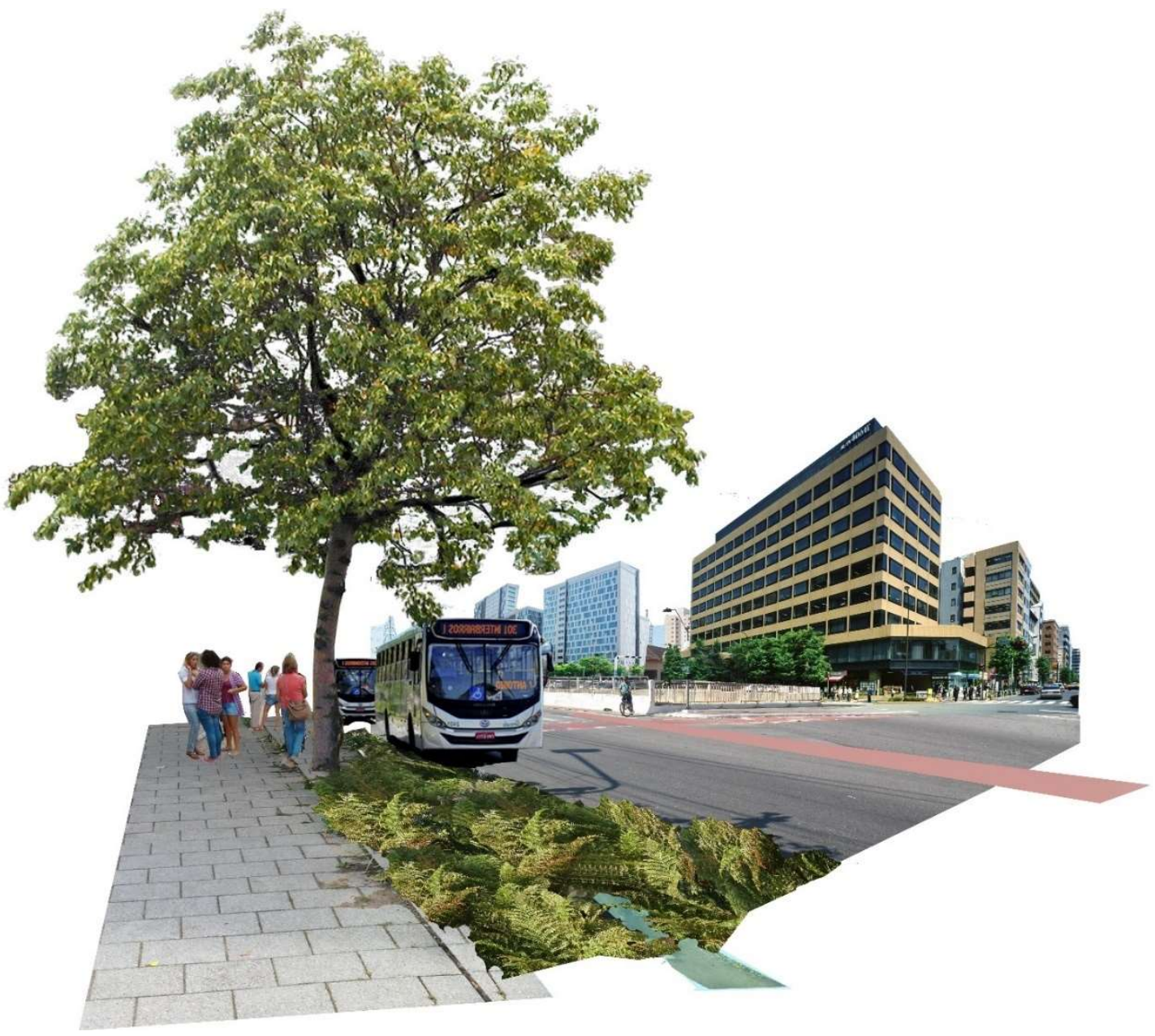

Fonte: elaboração própria. 


\subsection{CENÁRIO E FUTURO 3: RECONQUISTA DA VÁRZEA}

Neste cenário, há incremento populacional acumulado de $12 \%$ no período e crescimento econômico. Os Planos e Programas são efetivados de maneira parcial, sendo revistos entre 20242026, quando passam a adotar estratégias de Infraestrutura Verde Urbana para o fornecimento de distintos SE, definindo uma série de Eixos Multifuncionais para suporte da rede verde. A participação cidadã e os processos transdisciplinares estão presentes no planejamento, instalação, manutenção e monitoramento das propostas urbanas.

O PIMA é reformulado como Plano de Manejo da Floresta Urbana e passa a guiar as ações relacionada à cobertura vegetal arbórea na bacia. O envolvimento da população é ativo, tanto nas campanhas de arborização quanto no manejo dos resíduos sólidos, instalação de LID em suas residências e ocupação de espaços subutilizados por hortas urbanas. O Programa Córrego Limpo passa a adotar LID para o tratamento de efluentes, ou quando as cargas são extremas, associa Estações de Tratamento de Esgoto Compactas e instala tubulações mediante colaboração com equipe interdisciplinar a fim de fornecer SE culturais associados ao manejo das águas contaminadas. A mobilidade nas áreas mais planas da bacia é priorizada por modos ativos e transporte público, que aos poucos passa a ser movido por eletricidade. As linhas e conexões de ônibus são revistas e passam a atender melhor as demandas em toda a bacia. Rotas exclusivas para mobilidade ativa são definidas a partir dos vales aos Topos das Altas Colinas em toda a bacia, tornando os distintos compartimentos mais acessíveis. O Apoio Norte é redefinido como Eixo Multifuncional e prioriza a locomoção por transporte público de alta capacidade e por modos de transporte ativos. A mobilidade por veículos particulares é desestimulada. Os edifícios propostos passam a ter altura máxima limitada segundo estudos específicos, para não sobrecarregar os sistemas abióticos e evitar desserviços de regulação e culturais. São concebidos à escala da quadra, não do lote, incorporando estratégias de detenção das águas de chuva intrínsecas ao desenho dos Espaços Abertos, acessíveis à população e que informam as dinâmicas naturais das várzeas ao longo do tempo. A drenagem da bacia é beneficiada pelo espraiamento de LID em todas as tipologias de Espaços Abertos e pela instalação de reservatórios in-line no córrego Água Preta e em áreas de afluentes do Lauzane e Tabatinguera. Este último acompanha as obras de urbanização das favelas propondo um desenho integrado ao ambiente e permeado por LID. Os 
reservatórios off-line são desmembrados em estruturas de menor porte localizadas ao longo dos eixos dos córregos, formando uma sequência de praças e parques multifuncionais e com distintos níveis de integração verde-cinza. A instalação do Parque Lauzane é acompanhada de propostas legislativas municipais a fim de garantir a permanência da população atual na área. No caso do Mandaqui, a abertura do canal em quase toda a extensão do vale é prevista. Os fluxos veiculares, quando possível são desviados para vias adjacentes à avenida. A área ocupada pelo Compartimento da Paisagem "Planícies Aluviais", é incorporada aos Planos e normas de influência no uso e ocupação do solo como áreas de alto desempenho ambiental que poderão receber edifícios anfíbios, ou seja, adaptados a esta condição. As galerias pluviais atuais serão parcialmente mantidas como forma de dar vazão aos grandes volumes de chuva e não acarretar a perda das áreas ocupadas pela Infraestrutura Verde instalada e utilizada pelas pessoas diariamente. Nas áreas onde o Mandaqui já é aberto, galerias são instaladas sob o sistema viário, otimizando o espaço ocupado por esta infraestrutura e reservatórios anomatosados são incorporados nas áreas atualmente ocupadas por grandes estacionamentos e integradas ao eixo. Quanto aos parques da bacia, as duas ZEPAM serão abertas ao público, assim como áreas atualmente inacessíveis. Novas praças e parques serão propostos em espaços abertos requalificados, com atenção especial às áreas de pior demanda (Figuras 84, 85 e 88).

Figura 87: Estratégia de reconquista da várzea.

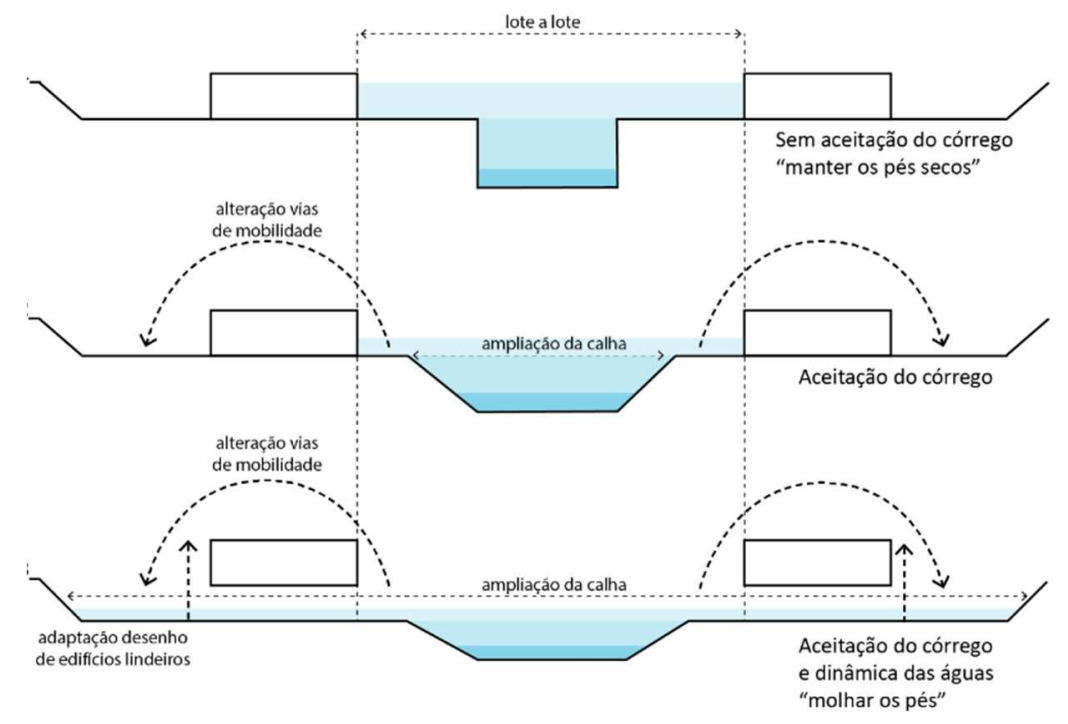

Fonte: elaborado pela autora. 
Aplicação dos princípios da IEVu:

- Multifuncionalidade: terá distintas expressões pela bacia, relacionada aos Compartimentos da Paisagem à aptidão dos Espaços Abertos e dos LIDs e às demandas dos habitantes. As sinergias estarão presentes ao longo de todo o eixo Mandaqui, relacionando a regulação hídrica à oferta de outros SE de regulação e culturais que beneficiam a mobilidade ativa, ampliada a parques e praças híbridos ao longo do eixo. Os desserviços relacionados à contaminação atmosférica são reduzidos devido ao incentivo aos modos de mobilidade ativa, desincentivo ao uso de veículos particulares e transição a veículos elétricos para o transporte público. A aceitação das águas em toda a extensão da Planície Aluvial compreende a existência de distúrbios ecossistêmicos e a alternância entre períodos sinérgicos e de trade-off típicos desses compartimentos da paisagem. A minimização dos trade-offs nesse caso, não estará relacionada à tentativa de supressão do distúrbio, mas de alerta e proteção das pessoas aos eventos mais extremos.

- Conectividade: é evidenciada pelas propostas de instalação de parques lineares e distintos Eixos Multifuncionais de estruturação a uma rede verde, se estendendo pelos distintos compartimentos da bacia e evidenciando a relação entre Polos, Fragmentos e Espaços Abertos de distintas dimensões. A aplicação do Plano de Manejo da Floresta Urbana e de LID de micro drenagem colaborarão com o aumento das áreas verdes em vias de larguras variadas e a instalação de áreas verdes públicas em áreas de maior demanda e abertura das ZEPAM ao público estabelecerá novos pontos de ancoragem da rede. Áreas verdes externas à bacia, porém dentro do raio de influência, compostas por uma porção do Horto Florestal e parte do Campo de Marte, passam a ser acessíveis estimulando a extensão dos eixos a escalas mais amplas que a bacia.

- Múltiplas escalas: as escalas locais, do sítio específico, eixos e bacia são contempladas pelas estratégias, projetando extensões a escalas urbanas ainda mais abrangentes, externas à bacia.

- Importância do contexto: os projetos instalados contam com a participação ativa da população, com o intuito de resguardar a identidade do lugar. Os Compartimentos da Paisagem são incorporados aos Planos revisados e passam a ser respeitados. Quanto às 
estratégias de drenagem e a aptidão dos Espaços Abertos e LID, em fornecer distintos SE, são discutidos de acordo com as demandas locais da população e àquelas de regulação, provisão e habitat.

- Integração verde-cinza: o córrego Mandaqui passa a correr aberto. As estratégias de drenagem consideram a criação de um maior número de reservatórios off-line espraiados pela bacia e instalados sob a Infraestrutura de Mobilidade com o intuito de reduzir a profundidade e o tamanho daqueles propostos pelo Caderno de bacia Hidrográfica e não competir por áreas públicas verdes ou não, utilizadas pelas pessoas durante atividades de recreação, esporte e lazer.

- Processo transdisciplinar: é feita a adequação dos processos participativos iniciados durante as revisões do PDE e LPUOS entre 2014 e 2016, com o desenvolvimento de equipes transdisciplinares para o desenvolvimento de estratégias e propostas pontuais na bacia que levam à adequação dos perímetros de ação, instalação, manutenção e monitoramento.

Figura 88: Futuro Desejável- Reconquista da Várzea.

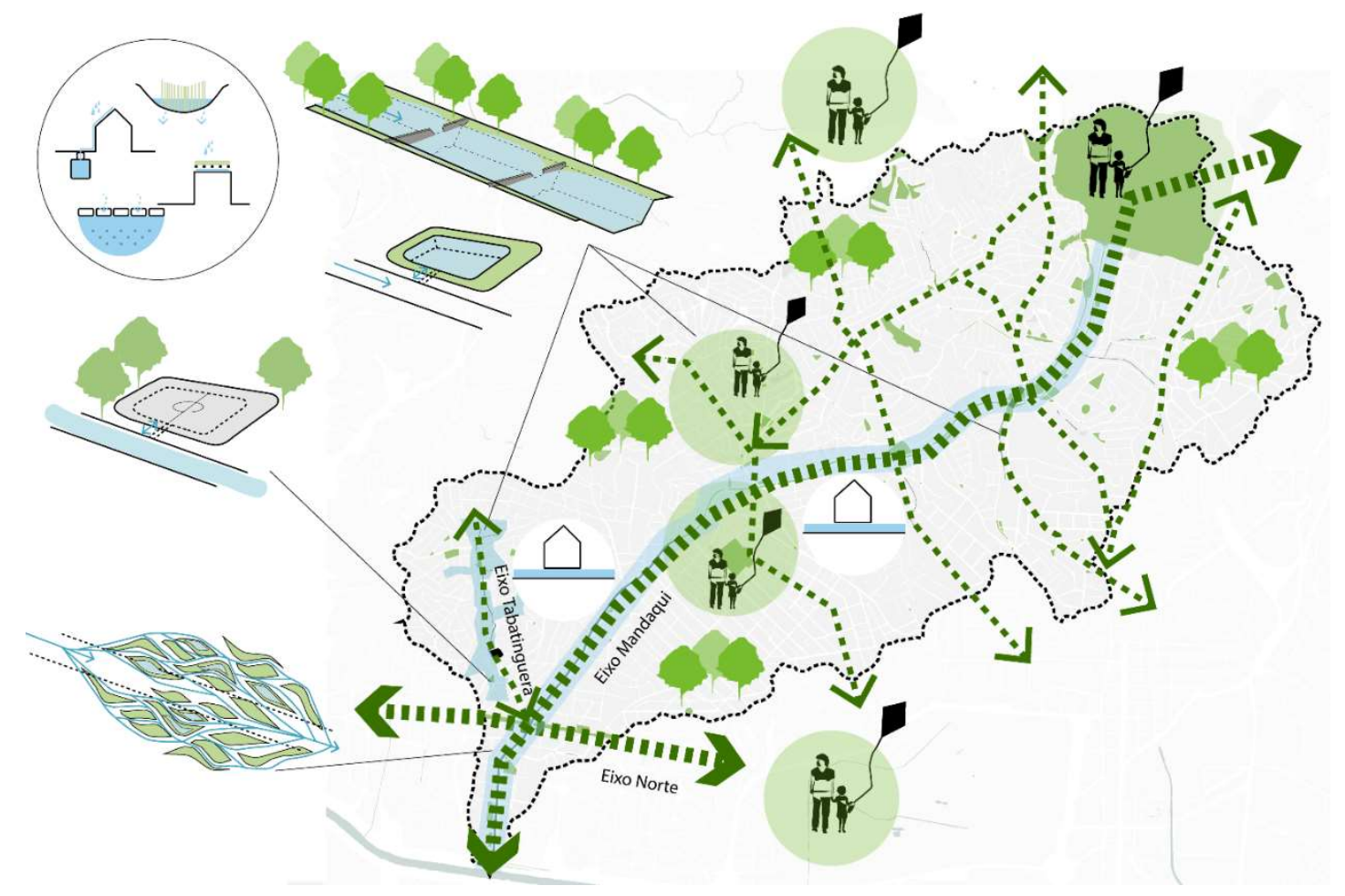

Fonte: elaborado pela autora. 


\section{Acesso aos critérios:}

- Alterações no uso e ocupação de solo: o conjunto de quadras lindeiras à avenida Caetano Álvares é alvo de alteração da zonificação, passando a compor as áreas de alto desempenho ambiental. Lotes abandonados e áreas subutilizadas recebem ZEIS e novos Espaços Abertos.

- Quantidade, qualidade e acessibilidade às áreas verdes: as duas ZEPAM (Tipos 1 e 2) são abertas ao público e três parques lineares são criados ou requalificados (Tipo 3). Corredores verdes são criados ao longo das vias, conectando distintos espaços abertos e criando rotas exclusivas para a mobilidade ativa.

- Utilização de técnicas LID: a utilização de técnicas LID para a drenagem urbana em micro e macroescalas é aplicada em toda a bacia, nas distintas escalas.

Figura 89: Colagem. Futuro Desejável: Reconquista da Várzea

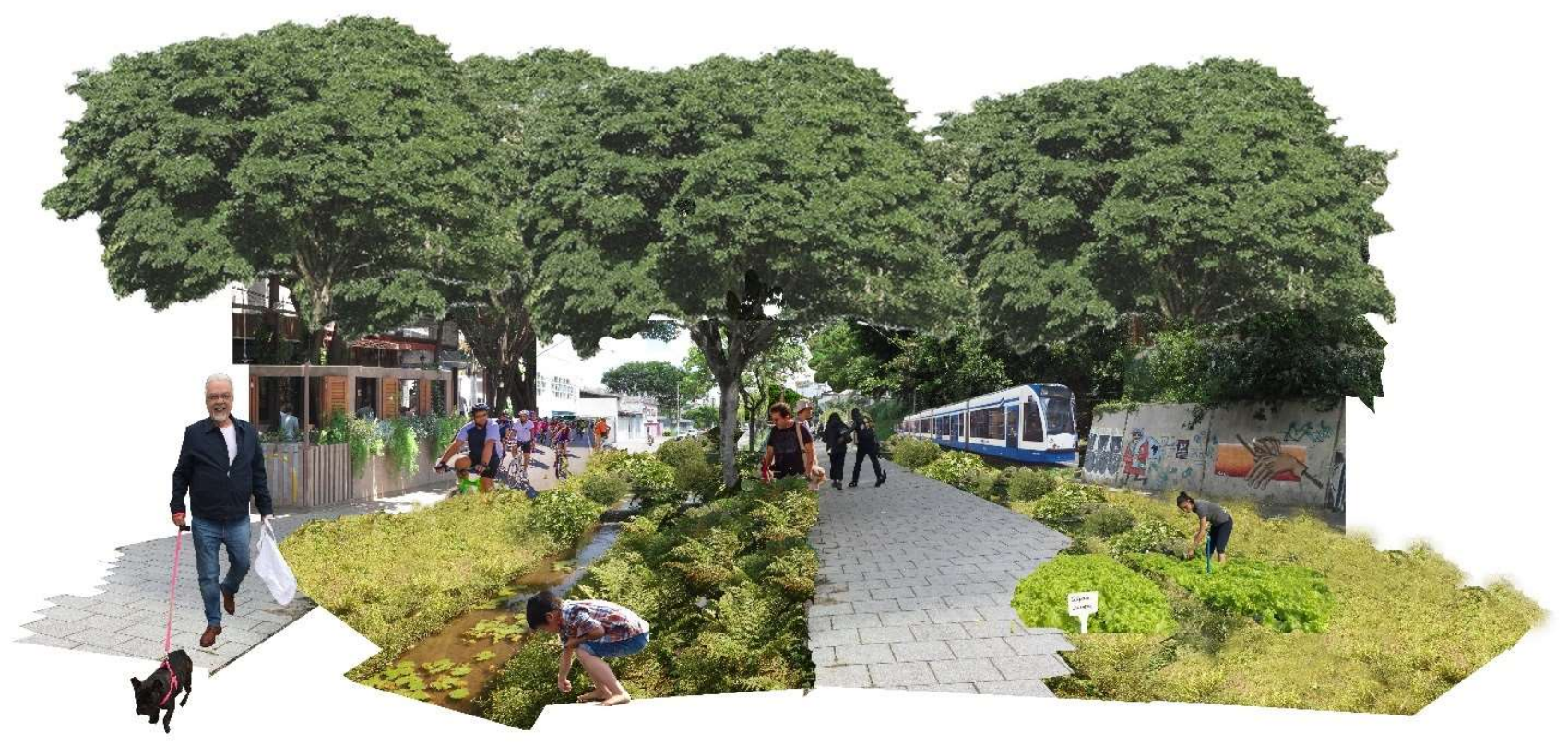

Fonte: elaborado pela autora. 


\subsection{CONSIDERAÇÕES PARCIAIS- FUTUROS DESEJÁVEIS}

Os Futuros Desejáveis apresentaram três possibilidades para a instalação de Eixos Multifuncionais no Mandaqui. Todas levaram em consideração estratégias de IEV e o fornecimento dos Serviços Ecossistêmicos, a fim de possibilitar o espraiamento de uma rede de Espaços Abertos. As expressões dos seis princípios de Infraestrutura Verde foram variadas, de acordo com as especificações determinadas pelo conjunto de agentes que delimitou os cenários de enquadramento dos Futuros Desejáveis. Os Quadros 19 e 20 resumem essas expressões, e apresentam o faseamento de cada proposta ao longo de períodos temporais definidos a cada revisão dos Planos municipais, relacionados ao uso e ocupação do solo. A discussão da pergunta que rege o capítulo será feita nas Considerações Finais da tese.

Quadro 19: Faseamento de implantação.

\begin{tabular}{|c|c|c|c|}
\hline $\begin{array}{c}\text { Progressão } \\
\text { temporal }\end{array}$ & C1 & $\mathrm{C2}$ & C3 \\
\hline 2020-2024 & $\begin{array}{c}\text { Formação de organizações } \\
\text { cidadãs. Fechamento de } \\
\text { vias aos domingos e } \\
\text { feriados }\end{array}$ & $\begin{array}{l}\text { Terminal Mandaqui e vias } \\
\text { exclusivas para ônibus no eixo; } \\
\text { Arborização das calçadas; } \\
\text { Abertura ZEPAM Niazi Chohfi e } \\
\text { praça pública }\end{array}$ & $\begin{array}{c}\text { Alteração de rotas de } \\
\text { transporte para vias } \\
\text { auxiliares; Abertura ZEPAM } \\
\text { Niazi Chohfi e praça pública; } \\
\text { Incorporação de IEVu e SE nos } \\
\text { Planos e Programas; Plano de } \\
\text { Manejo da Floresta Urbana }\end{array}$ \\
\hline 2024-2034 & $\begin{array}{l}\text { Arborização e instalação de } \\
\text { LIDs pontuais. Abertura de } \\
\text { praça pública; Incremento } \\
\text { de áreas ZEIS. Urbanização e } \\
\text { obras de drenagem no } \\
\text { Tabatinguera }\end{array}$ & $\begin{array}{l}\text { Urbanização e obras de } \\
\text { drenagem Tabatinguera; } \\
\text { Enterramento Linhão; } \\
\text { Desapropriações Lauzane }\end{array}$ & $\begin{array}{c}\text { Instalação de LIDs e manejo } \\
\text { arbóreo; Urbanização e obras } \\
\text { de drenagem Tabatinguera; } \\
\text { Parque Lauzane e sequência } \\
\text { de praças reservatórios e } \\
\text { piscininhas sob viário; } \\
\text { Urbanização de favelas } \\
\text { ZEPAM Invernada }\end{array}$ \\
\hline 2034-2044 & $\begin{array}{l}\text { Arborização e instalação de } \\
\text { LIDs pontuais. Piscinões } \\
\text { fechados do Lauzane e } \\
\text { Tabatinguera, remodelação } \\
\text { do canal aberto }\end{array}$ & $\begin{array}{c}\text { Apoio norte, arborizado e com } \\
\text { ciclovia. Urbanização de favela e } \\
\text { abertura parcial ZEPAM } \\
\text { Invernada; Parque Linear } \\
\text { Lauzane e piscinões Lauzane e } \\
\text { Mandaqui }\end{array}$ & $\begin{array}{c}\text { Abertura do Mandaqui e } \\
\text { trecho do Eixo Multifuncional } \\
\text { Norte; Abertura ZEPAM } \\
\text { Invernada e áreas acessíveis } \\
\text { ao Parque Campo de Marte e } \\
\text { Horto Florestal. }\end{array}$ \\
\hline
\end{tabular}

Fonte: elaborado pela autora. 
Quadro 20: Comparativo entre os princípios de IEVu e os Cenários Futuros.

\begin{tabular}{|c|c|c|c|}
\hline Princípios de IEVu & C1 & $\mathrm{C2}$ & C3 \\
\hline Multifuncionalidade & $\begin{array}{l}\text { Pontual: Usos alternados } \\
\text { dos espaços públicos; } \\
\text { Ocupação de áreas } \\
\text { subutilizadas por distintas } \\
\text { atividades }\end{array}$ & $\begin{array}{l}\text { Limitada: Ao longo do } \\
\text { Parque linear; Novas vias } \\
\text { são acompanhadas por } \\
\text { maciços verdes e } \\
\text { infraestrutura para } \\
\text { mobilidade ativa }\end{array}$ & $\begin{array}{c}\text { Abrangente: } \\
\text { potencialização de } \\
\text { sinergias ao longo do Eixo } \\
\text { e nas distintas escalas de } \\
\text { Espaços Abertos }\end{array}$ \\
\hline Conectividade & $\begin{array}{l}\text { Tendência de melhora } \\
\text { devido à arborização e } \\
\text { LIDs em locais específicos }\end{array}$ & $\begin{array}{c}\text { Arborização e LIDs em } \\
\text { vias específicas colabora } \\
\text { com a conectividade das } \\
\text { áreas verdes. }\end{array}$ & $\begin{array}{l}\text { Plano de Floresta Urbana } \\
\text { e Instalação de LIDs com } \\
\text { ênfase na conexão das } \\
\text { áreas verdes }\end{array}$ \\
\hline $\begin{array}{l}\text { Integração verde- } \\
\text { cinza }\end{array}$ & $\begin{array}{l}\text { LIDs de microdrenagem } \\
\text { instalados em áreas } \\
\text { verdes; cisternas nas } \\
\text { residências }\end{array}$ & $\begin{array}{l}\text { Sequência verde e cinza, } \\
\text { associada a Parque linear } \\
\text { e piscinão no Lauzane. } \\
\text { LIDs associados ao } \\
\text { sistema tradicional }\end{array}$ & $\begin{array}{c}\text { LIDs associados ao } \\
\text { sistema tradicional; } \\
\text { otimização de sistemas de } \\
\text { mobilidade integrado à } \\
\text { drenagem e liberação de } \\
\text { áreas verdes }\end{array}$ \\
\hline Múltiplas escalas & $\begin{array}{l}\text { Lote, quadra e eixos } \\
\text { Mandaqui e } \\
\text { Tabatinguera, integrado a } \\
\text { ação no Lauzane }\end{array}$ & $\begin{array}{c}\text { Perímetros de ação } \\
\text { definem distintas escalas }\end{array}$ & $\begin{array}{c}\text { Lote, quadra, bairro, bacia } \\
\text { e direcionamento além } \\
\text { bacia }\end{array}$ \\
\hline $\begin{array}{l}\text { Importância do } \\
\text { Contexto }\end{array}$ & $\begin{array}{l}\text { Atendimento a demandas } \\
\text { locais com forte caráter } \\
\text { identitário. } \\
\text { Compartimentos da } \\
\text { Paisagem são } \\
\text { considerados para a } \\
\text { instalação de LIDs e } \\
\text { plantio de árvores }\end{array}$ & $\begin{array}{c}\text { Propostas replicam } \\
\text { soluções genéricas. Os } \\
\text { Compartimentos da } \\
\text { Paisagem são } \\
\text { considerados para a } \\
\text { instalação de LIDs e } \\
\text { arborização }\end{array}$ & $\begin{array}{l}\text { Planície Aluvial como área } \\
\text { de alto desempenho; } \\
\text { Compartimentos da } \\
\text { Paisagem integrados aos } \\
\text { Planos; população tem } \\
\text { papel fundamental } \\
\text { quanto à potencialização } \\
\text { da identidade do lugar }\end{array}$ \\
\hline $\begin{array}{c}\text { Processo } \\
\text { Transdisciplinar }\end{array}$ & $\begin{array}{l}\text { Atividade cidadã intensa } \\
\text { e atendimento a } \\
\text { demandas por áreas } \\
\text { recreativas pelo poder } \\
\text { público }\end{array}$ & $\begin{array}{l}\text { Presença incisiva dos } \\
\text { governos municipal e } \\
\text { estadual, desarticulados } \\
\text { de processos } \\
\text { participativos e } \\
\text { associados a atores } \\
\text { privados responsáveis } \\
\text { pelos desenvolvimentos } \\
\text { imobiliários e parte das } \\
\text { ZEIS na bacia }\end{array}$ & $\begin{array}{l}\text { Integração de agentes } \\
\text { públicos, privados, } \\
\text { acadêmicos e população } \\
\text { na proposta, instalação e } \\
\text { manutenção das áreas } \\
\text { verdes }\end{array}$ \\
\hline
\end{tabular}

Fonte: elaborado pela autora. 
O Quadro 21, acessa os dados referentes ao critério acessibilidade às áreas verdes em cada um dos Futuros Desejáveis, a fim de termos um parâmetro das possibilidades de mudança na bacia. Atualmente os parques de área entre 0,5 5 ha são acessíveis a cerca de 37.326 habitantes, a estimativa é que esse número possa aumentar para até 161.718 até 2044 (C3). Quanto aos parques de dimensões entre $100 \leq 500$ ha, a abertura da Invernada da Polícia Militar tem o potencial de atender, somente na bacia do Mandaqui aproximadamente 291.102 pessoas, cerca de $90 \%$ da população atual da bacia. O acesso a áreas maiores que as atuais, do Horto, e a abertura de parte do Campo de Marte como Parque marcarão uma diagonal de acessibilidade através da bacia, podendo ter grande impacto na qualidade de vida das pessoas. Os cálculos apresentados tem a limitação de não considerarem todos os LIDs e a Floresta Urbana, mas demonstram uma possibilidade real e acessível de aumentar a quantidade e a qualidade do verde na bacia, reintroduzindo ou potencializando o fornecimento de uma ampla de gama de Serviços Ecossistêmicos. A Figura 87, representa os distintos buffers de distância associados aos novos parques, exemplificando o que ocorreria no caso do Futuro Desejável: Reconquista da Várzea, com a formação de uma série de possíveis Eixos Multifuncionais.

Quadro 21: Estimativa de habitantes beneficiados pela proximidade às áreas verdes em cada cenário.

\begin{tabular}{|l|c|c|c|c|}
\hline & $\begin{array}{c}\text { Habitantes } \\
\text { beneficiados } \\
\text { atualmente }\end{array}$ & C1 & C2 & C3 \\
\hline$>\mathbf{0 . 5} \leq \mathbf{5}$ & 37326 & 48712 & 71469 & 161718 \\
\hline$>\mathbf{1 0} \leq \mathbf{1 0 0}$ ha & 60262 & 60262 & 60262 & 60262 \\
\hline$>\mathbf{1 0 0} \leq \mathbf{5 0 0}$ ha & - & - & 291102 & 291102 \\
\hline $\begin{array}{l}\mathbf{5 0 0} \text { ha } \\
\text { (Unidades de } \\
\text { Conservação) }\end{array}$ & 159670 & 159670 & 159670 & 159670 \\
\cline { 2 - 5 } & 315342 & 315342 & 315342 & 315342 \\
\hline
\end{tabular}

Fonte: elaborado pela autora. 
Figura 90: Acessibilidade às áreas verdes- Reconquista da Várzea.
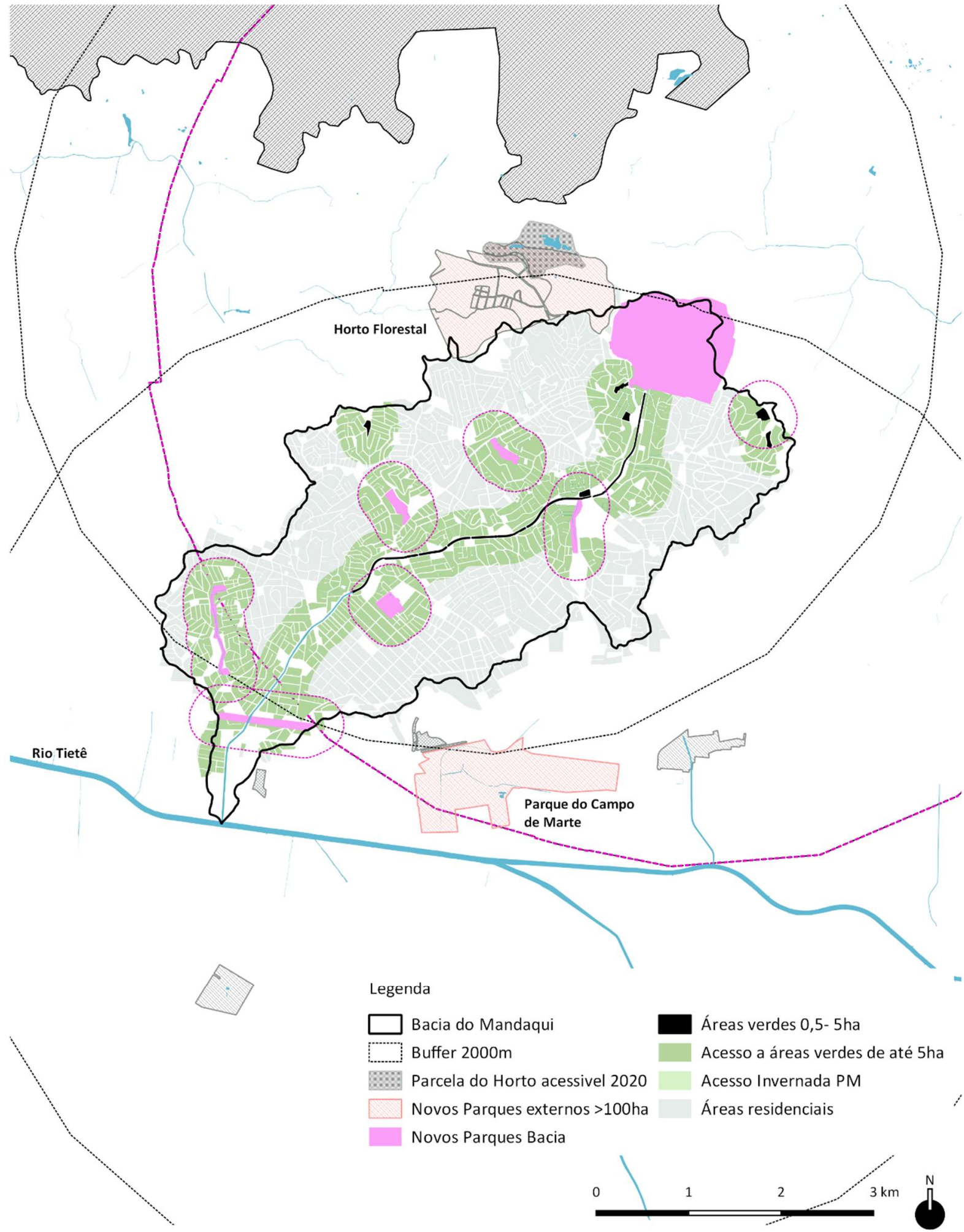

Legenda

Bacia do Mandaqui

Buffer 2000m

2...: Parcela do Horto acessivel 2020

Novos Parques externos $>100$ ha

Novos Parques Bacia

Fonte: elaborado pela autora.

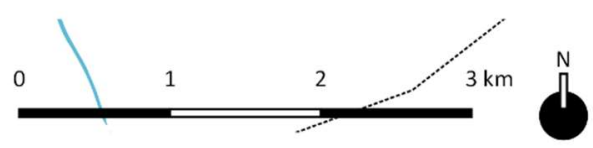

Acesso a áreas verdes de até 5 ha Acesso Invernada PM Áreas residenciais 


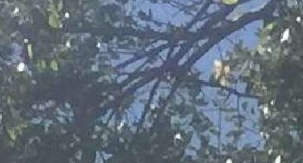

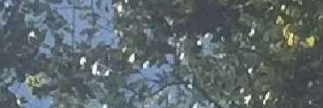

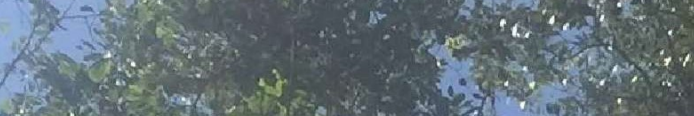

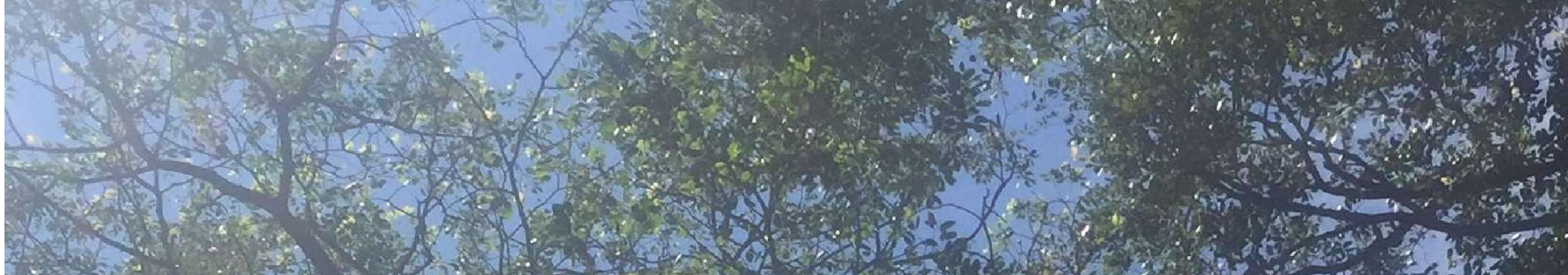

a $x^{2}=0$

7

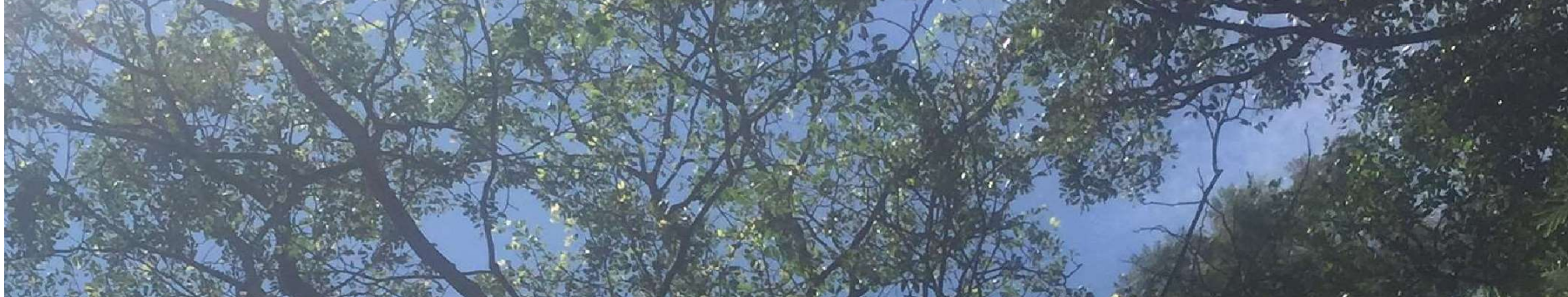

(3.
CONSID
FUNAIS

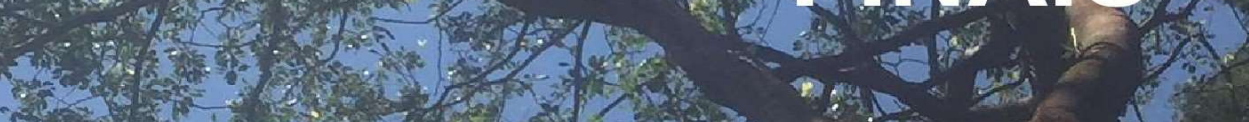

\section{CONSIDERAÇÕES}

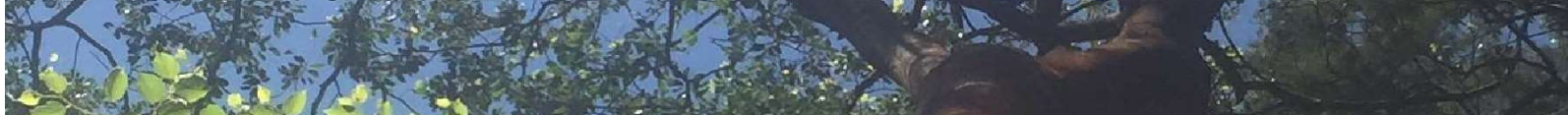

$+4 x^{2}+3$

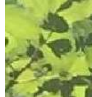

(2)

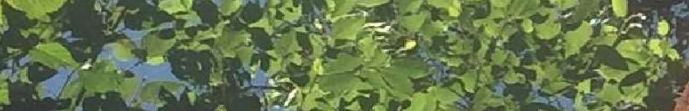

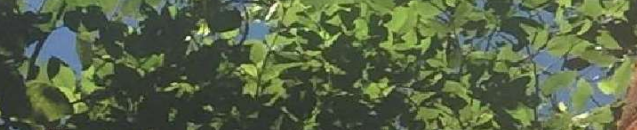

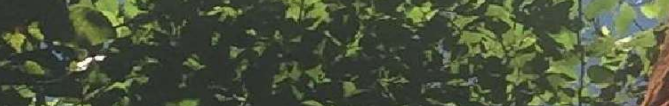

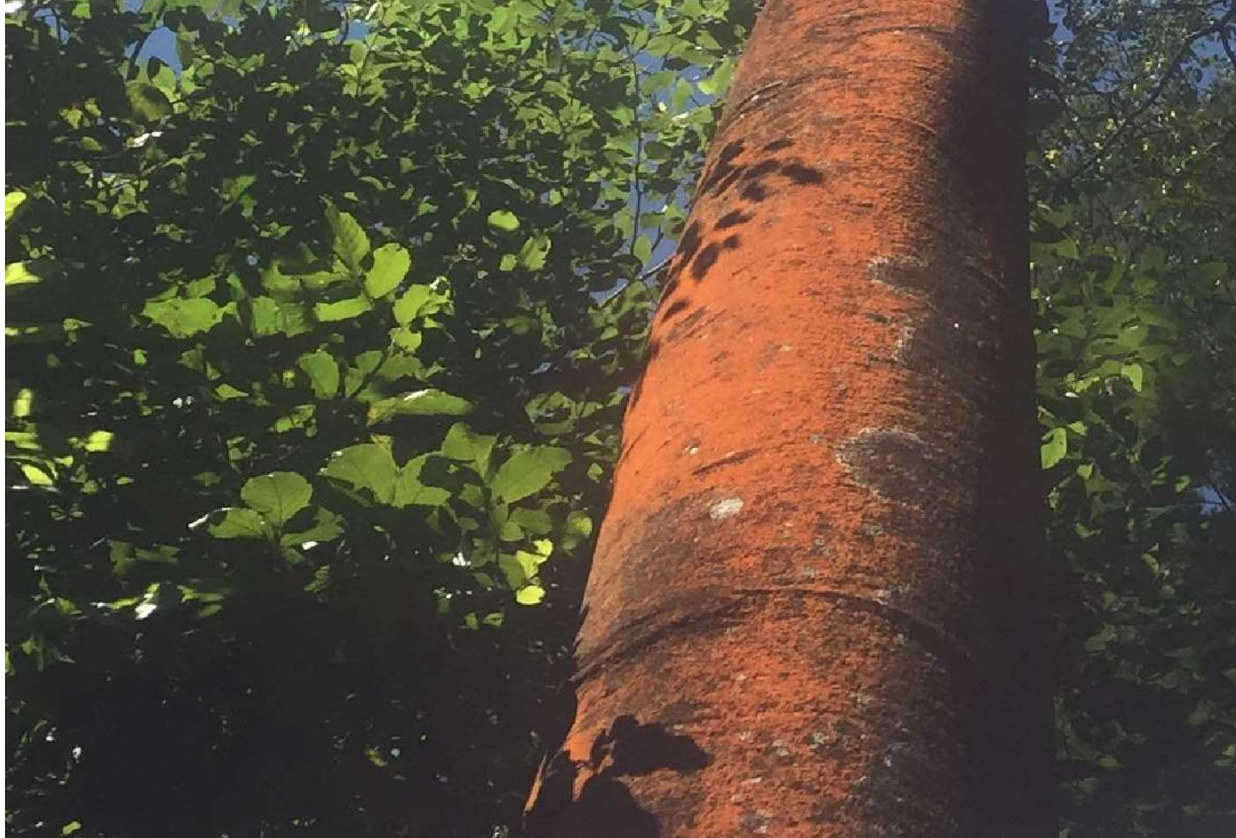

ite

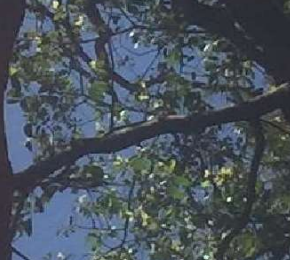

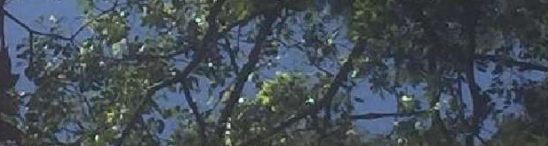

2

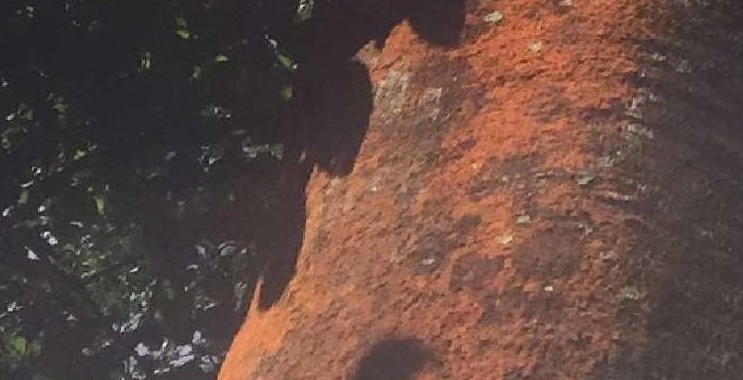


Ao longo da tese viemos respondendo perguntas derivadas da hipótese:

Os fundos de vale são áreas de alto desempenho ambiental e refletem a oportunidade de serem convertidos em Eixos Multifuncionais, capazes de estruturar uma rede conectada de espaços abertos, catalisadora do verde e do azul no interior da trama urbana oferecendo diversos Serviços Ecossistêmicos.

As Considerações Finais da tese irão acessar cada uma dessas questões e discutir o atendimento às lacunas identificadas inicialmente e à hipótese proposta.

a) Como os princípios de Infraestrutura Verde e os Serviços Ecossistêmicos podem ser associados para dar suporte ao desenho de Eixos Multifuncionais?

A primeira pergunta da tese atendeu à lacuna de conhecimento: “Aportar a integração conceitual entre Infraestrutura Verde (IEV) e Serviços Ecossistêmicos (SE) e sua relevância para aplicação na escala urbana." Para tal, foram feitas três sínteses principais. A primeira relacionou diretamente os termos Infraestrutura Verde e Serviços Ecossistêmicos para aplicação à escala urbana. A segunda se baseou em identificar a aptidão dos Espaços Abertos em fornecer Serviços Ecossistêmicos, adaptada ao contexto urbano de São Paulo e especificamente da bacia do Mandaqui. E finalmente, a terceira, contribuiu com a identificação de critérios de acessibilidade às áreas verdes urbanas que poderão compor estratégias de ação relacionadas à melhora da qualidade de vida. Quem se beneficia, onde e quando se beneficiam dos SE são aportes metodológicos importantes para a compreensão de suas demandas e fornecimento.

A definição de princípios de Infraestrutura Verde para aplicação urbana e sua associação aos Serviços Ecossistêmicos se mostrou útil e de aplicação variável de acordo com a escala abordada. Equalizações terminológicas foram necessárias quanto às definições de funções, serviços e benefícios ecossistêmicos. No geral, todos os princípios são aplicados de forma concisa à escala da bacia. Uma vez abordada a escala do eixo, os estudos de Conectividade e as relações Multi escalares já deverão estar definidos. Quanto à Multifuncionalidade, os aportes dos Serviços 
Ecossistêmicos conferem uma flexibilidade à escala abordada, pois distintos serviços poderão estar relacionados a distintas escalas e diversos tipos e tamanhos de Espaços Abertos. A Integração verde-cinza foi fundamental para compreender as relações possíveis entre as infraestruturas e suas sinergias, trade-offs e desserviços. Tais relações foram priorizadas à escala do fundo de vale, porém são válidas para escalas muito menores, por exemplo, do desenho de cada tipologia LID. Em escalas próximas ou superiores às da bacia hidrográfica essas relações soam como diretrizes gerais de planejamento e não incorporadas ao desenho. A Importância do Contexto em relação aos SE se relaciona à identificação, principalmente dos Serviços Culturais, dependente da percepção da população e de perspectivas às vezes subjetivas, estando mais presente em escalas de sítio específico. Na escala da bacia o contexto é abordado enquanto Compartimento da Paisagem. Finalmente, embora a associação dos princípios da Infraestrutura Verde aos Serviços Ecossistêmicos exija que equipes transdisciplinares sejam formadas, e esse vem sendo um dos principais empecilhos a este tipo de pesquisa, as contribuições pontuais, ou por equipes menores já vem colaborando e motivando distintas aplicações e futuras pesquisas sobre o tema.

A segunda lacuna abordada pela pesquisa: "Analisar possíveis sinergias, trade-offs e desserviços existentes na integração entre as Infraestruturas Verde e cinza e como seria possível potencializar as sinergias e minimizar os trade-offs e desserviços ecossistêmicos." Se relaciona com os aportes das perguntas b), c), d) e e). A seguir, cada uma dessas perguntas será brevemente discutida.

b) Qual a potencial integração da Infraestrutura Verde para a regulação hídrica nos distintos compartimentos da paisagem?

Propor soluções que retomem processos ecológicos na cidade exige compreendermos o funcionamento da paisagem e seus impactos na urbanização e vice-versa, além da localização e caracterização dos distintos Espaços Abertos passíveis de potencializar funções e serviços ecossistêmicos. A Compartimentação da Paisagem forneceu um panorama dessas relações e se mostrou um método útil para o diagnóstico da bacia hidrográfica. A sistematização das etapas e 
camadas da paisagem relacionadas durante a análise, em formato de Guia Procedural (Figura 88), auxiliou a aplicação do método e poderá ser utilizado para sua réplica do método, agilizando os procedimentos de cada etapa. A busca por Espaços Abertos englobou tipologias verdes e não verdes, descontínuas ou contínuas a fim de encontrar o maior número de possibilidades para receber a IEV. A sobreposição das duas bases cartográficas oferece o panorama da bacia quanto às funções ecossistêmicas relacionadas ao fornecimento de serviços de regulação hídrica. Será interessante poder desdobrar as análises a outras funções da paisagem, associada a conjuntos distintos de serviços fornecidos. Complementarmente, as soluções LID são associadas aos Compartimentos da Paisagem, especificando quais tipologias são mais adequadas a cada setor.

c) Qual a aptidão e os possíveis desserviços associados aos Espaços Abertos da bacia?

A caracterização dos Espaços Abertos quanto à sua origem ecológica e tipologia urbana contribuiu para que a aptidão em fornecer distintos Serviços Ecossistêmico fosse elaborada. Além disso, os desserviços possíveis e ações para evitá-los ou mitigá-los foram sugeridos. A compreensão dos SE Culturais foi limitada pela falta de acesso à população em distintos pontos da bacia, estando relacionada a amostragens no entroncamento das avenidas Imirim e Eng ${ }^{\circ}$. Caetano Álvares e observações em campo. Quanto aos desserviços, um processo mais intensivo e transdisciplinar ainda precisará ser conduzido, porém a contribuição da pesquisa a partir desse panorama terá importância para que efeitos negativos sejam evitados e impactos positivos sejam otimizados. É importante ressaltar a alta representatividade do sistema de mobilidade como Espaço Aberto de maior predominância na bacia, quando não consideramos as ZEPAM, e seu potencial como rede receptora e articuladora da Infraestrutura Verde. Baseados nessa afirmação, sugere-se que sejam consideradas diretivas para a reestruturação da mobilidade na escala da bacia, conectada a redes mais eficientes a escala da cidade e metrópole, que contemplem: trabalho intersetorial e com a população; visão holística da mobilidade, predominando os modos ativos, coletivos e não poluentes sobre os modos individuais e contaminantes; pensar o desenho desses espaços abertos de forma completa, considerando as distintas funções que deve cumprir, 
além dos principais Serviços Ecossistêmicos que deverão estar associados às áreas verdes instaladas.

Outro ponto a destacar, são os métodos apresentados nos Subcapítulos 4.1 e 4.2- Parte I e aplicados durante os Capítulos 3 e 4- Parte II, para responder às questões b) e c). Com a finalidade de estruturar um modelo aplicado que relacione as distintas bases de dados e processos analíticos, foi sistematizado um diagrama, em formato de Guia Procedural, para que a Compartimentação da Paisagem possa ser elaborada em outras bacias hidrográficas, com o objetivo de instalação de uma rede de Infraestrutura Verde capaz de fornecer distintos Serviços Ecossistêmicos (Figura 88).

Figura 91: Guia Procedural para Compartimentação da Paisagem focada na Infraestrutura Verde.

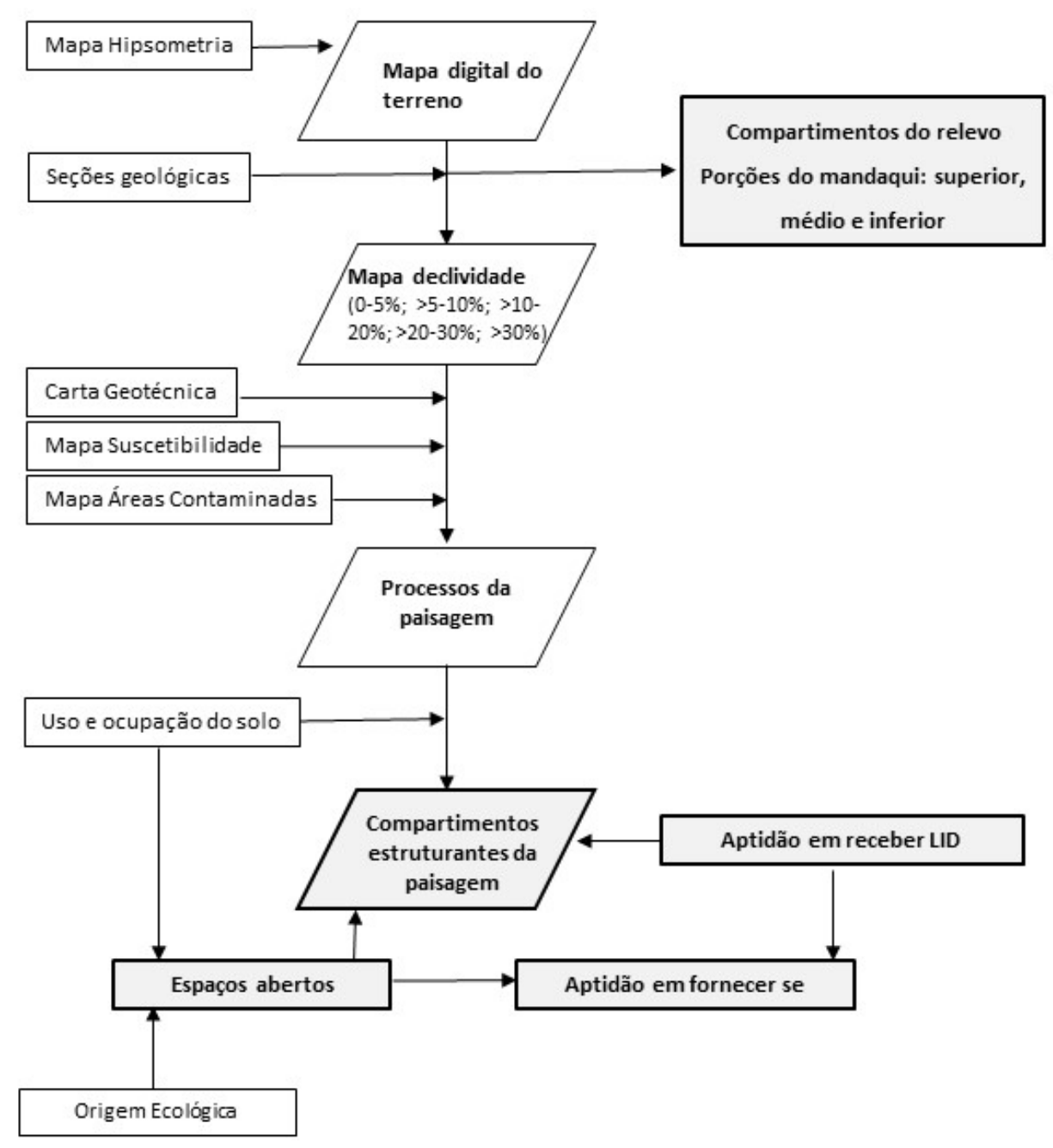

Fonte: elaborado pela autora. 
d) Quais as sinergias, trade-offs e desserviços relacionados às Infraestruturas Verde e cinzas no fundo de vale?

Os sistemas de infraestruturas urbanas tradicionais são reconhecidos por sua monofuncionalidade e, portanto, não carregam aportes intrínsecos a seu funcionamento para gerar sinergias. Nos fundos de vale as infraestruturas de drenagem, mobilidade e verde compartilham ou competem pelo espaço restrito da várzea, contribuem e são beneficiadas por Serviços Ecossistêmicos distintos. O objetivo dessa análise foi compreender como a distribuição espacial relacionada à função desempenhada por uma infraestrutura influencia a outra e viceversa, identificando os períodos onde toda as funções ocorrem, com ou sem fornecimento de SE, e quando algum dos sistemas predomina sobre o outro. Os desserviços podem ser, em parte, previstos de acordo com as tipologias de vegetação e infraestrutura encontradas. Muitos desses aportes já vem sendo definidos em literatura.

e) Como é possível enfatizar as sinergias e reduzir os trade-offs e desserviços entre as infraestruturas no fundo de vale?

Conforme vimos nos Cenários Possíveis e Futuros Desejáveis, não existe somente uma resposta a esta pergunta. Propostas que consideram a aceitação dos processos naturais, terão que ponderar que sinergias e trade-offs estarão intrínsecos aos momentos de distúrbio e irão variar ao longo do tempo e durante eventos mais ou menos intensos de chuva. Ao relacionar as infraestruturas monofuncionais, nem sempre os trade-offs irão soar como negativos, mas uma necessidade de alternar usos do mesmo espaço, concebido originalmente para acomodar apenas uma atividade, mas que será adaptado ao longo do tempo e de acordo com as demandas locais, para receber outros tipos de uso. Essa certa flexibilização, daquilo que nos parece tão inflexível como o conjunto de infraestruturas tradicionais, confere a beleza dos ecossistemas urbanos, compostos por estruturas naturais e artificiais. 
Os fundos de vale são áreas de alto desempenho ambiental e refletem a oportunidade de serem convertidos em Eixos Multifuncionais, capazes de estruturar uma rede conectada de espaços abertos, catalisadora do verde e do azul no interior da trama urbana oferecendo diversos Serviços Ecossistêmicos?

É evidente que existam limites à instalação da Infraestrutura Verde em áreas urbanas. Porém, pensar a cidade como ecossistema evidencia processos e possibilidades suprimidos e esquecidos por uma ocupação do solo que vem se tornando generalista e quase automatizada ao longo do tempo. A oportunidade encontrada nas redes de sistemas infere um potencial real para pensarmos estas estruturas como Eixos Multifuncionais e catalizadores de uma rede muito mais extensa e que pode ser generosa às cidades e às pessoas, fornecendo Serviços Ecossistêmicos variados. O Eixo no fundo de vale, não se limita a estas áreas de alto desempenho, mas precisa necessariamente ser pensado a partir do entendimento da bacia hidrográfica reforçando a importância dos princípios de IEV.

A reunião de equipes transdisciplinares ainda é um desafio, mas processos multi e interdisplinares já vem avançando nesse sentido, exemplificados pelos Projetos Resiliência e Jaguaré, respectivamente, proporcionando experiencias de integração entre disciplinas para a construção e aperfeiçoamento das teorias e conceitos relacionados à Infraestrutura Verde e suas potenciais aplicações urbanas. A valoração de distintos Serviços Ecossistêmicos prestados por um mesmo local ou rede de IEV dependerá desses formatos de pesquisa.

Embora a tese não tenha se debruçado sobre o aspecto socioambiental, vale observar que muitos fundos de vale ainda não urbanizados de São Paulo, a exemplo das áreas do Tabatinguera na bacia do Mandaqui, são considerados resquícios urbanos, ocupados por população que encontra aí, a possibilidade do morar. As ações de saneamento, requalificação ambiental e habitação enfrentam grandes desafios nessas áreas, mas tem grandes possibilidades de inovação e de pensar as funções urbanas integradas às ambientais a fim de garantir o direito à cidade. No geral, a incorporação e potencialização de novas áreas verdes deverá ser acompanhada por uma série de medidas que consideram a realidade social local e os processos de gentrificação verde que poderão estar atrelados a estas melhorias. O verde urbano, acessível a todos, vem sendo 
proposto por órgãos internacionais como forma de melhorar a saúde e o bem estar, mas também pode ser subentendido como uma das funções sociais da cidade destacadas no artigo 182 da Constituição Federal, conforme segue:

"A política de desenvolvimento urbano, executada pelo poder público municipal, conforme diretrizes gerais fixadas em lei, tem por objetivo ordenar o pleno desenvolvimento das funções sociais da cidade e garantir o bem-estar de seus habitantes." (Art. 182, Constituição Federativa do Brasil, grifo nosso) ${ }^{68}$.

Essa discussão será de suma importância, mas é tema pra uma outra história.

${ }^{68}$ Brasil. Constituição Federal (Texto compilado até a Emenda Constitucional no 101 de 03/07/2019), Art. 182. Disponível em: <https://www.senado.leg.br/atividade/const/con1988/con1988 03.07.2019/art 182 .asp> Acessado em: 01/02/2020. 
AB'SABER, A.N. Geomorfologia do Sítio Urbano de São Paulo. Ateliê Editorial, Edição FACSimilar- 50 anos, 2007.

AHERN, J. Greenways as a Planning Strategy. Landscape and Urban Planning Journal, 33:1-3, p.131-155, 1995.

Spatial concepts, planning strategies and future scenarios: a framework method for integrating landscape ecology and landscape planning. In: KLOPATEK, J.; GARDNER, R. (eds.) Landscape Ecological Analysis: Issues and Applications, New York, Springer-Verlag Inc., pp. 175201, 1999.

. Green Infrastructure for cities: The spatial dimension. University of Massachusetts.

P.267-283, 2007.

From fail-safe to safe-to-fail: Sustainability and resilience in the new urban world. Landscape and Urban Planning, n. 100, p. 341- 343, 2011.

AHERN, J. et al. Measuring Landscapes: A Planner's Handbook. Island Press, 2012.

ANDERSSON, E. et al. Reconnecting Cities to the Biosphere: Stewardship of Green Infrastructure and Urban Ecosystem Services. Ambio- A Journal of the Human Environment, Volume 43, Issue 4, p. 445-453, 2014.

ANELLI, R. Redes de mobilidade e urbanismo em São Paulo das radiais/perimetrais do Plano de Avenidas à malha direcional PUB. Revista eletrônica Vitruvius, Disponível em:

<http://www.vitruvius.com.br/revistas/read/arquitextos/07.082/259 > Acesso em 21/01/2018.

BARÓ, F. Urban Green Infrastructure: Modeling and mapping ecosystem services for sustainable planning and management in and around cities. Ph.D. Thesis, Program in Environmental Science and Technology, Universitat Autonoma de Barcelona, 2016.

BÉLANGER, P. Landscape Infrastructure, Urbanism beyond Engineering. p. Ph. D Thesis, Landscape Architecture and Planning Program, Wageningen University, Holanda, 2013.

BENEDICT, M. A. e MCMAHON, E. T. Green Infrastructure: Smart Conservation for the 21st Century. Sprawl Watch Clearing House Monograph Series. Washington DC, 2002.

Press, 2006.

.Green Infrastructure, linking landscapes and communities. Washington, DC, Island 
BRAAT, L., TEN BRINK, P (eds.). The Cost of Policy Inaction, the case of not meeting the 2010 biodiversity target. Wageningen, Alterra, Alterra-rapport 1718, 2008.

BOLUND, P., HUNHAMMAR, S. Ecosystem services in urban areas. Ecological Economics 29, p. 293-301, 1999.

BURKHARD et al. Landscapes 'Capacities to Provide Ecosystem Services - a Concept for LandCover Based Assessments. Landscape Online, 15, p.1-22, 2009.

BURKHARD et al. Mapping ecosystem service supply, demand and budgets. Ecological Indicators Volume 21, p. 17-29, 2012.

CATUZZO, H., LOMBARDO, M.A. Telhados verdes: possibilidade de redução da ilha de calor na metrópole de São Paulo. Universidade de São Paulo, 2011.

CAVALHERO, F.; DEL PICCHIA, P. C. D. Áreas verdes: conceitos, objetivos, diretrizes para o planejamento. In: CONGRESSO BRASILEIRO SOBRE ARBORIZAÇÃO URBANA, 1., E ENCONTRO SOBRE ARBORIZAÇÃO URBANA, 4. Vitória, 13 a 18 de setembro, 1992. Anais, Vitória, 1992. p.2938

COHEN-SHACHAM, E. et al. (ed.). Nature-based Solutions to address global societal challenges. International Union for Conservation of Nature (IUCN), Gland, Switzerland, 2016.

CHIESA, P.; MAGNOLI, M.M. Paisagem não é jardinagem. 9o Encontro Nacional de Ensino de Paisagismo em Escolas de Arquitetura e Urbanismo no Brasil, Universidade Federal do Paraná, 2008. Disponível em < http://www.enepea.ufpr.br/paisagemsite.html > Acessado em: $15 / 06 / 2020$.

CONSTANZA et al. The Value of the World's Ecosystem Services and Natural Capital. Nature, 387(15), p. 253-260, 1997.

CORMIER, N. S.; PELLEGRINO, P.R.M. Infra-estrutura Verde: uma estratégia paisagística para a água urbana. Paisagem Ambiente: ensaios - n. 25 - São Paulo - p. 125 - 142 - 2008.

COSTA, C.S. Can We Change Processes in Our Cities? Reflections on the Role of Urban Mobility in Strengthening Sustainable Green Infrastructures. Journal of Traffic and Logistics Engineering Vol. 2, No. 2, June 2014.

CRESWELL, J. W. Research Design: qualitative, quantitative, and mixed methods approaches. California, SGA, 2009.

CHRISTOFOLETTI, A. Geomorfología Fluvial. São Paulo, ed. Edgard Blücher, 1981. 
DAVIES et al. Green Infrastructure Planning Guide. 2006

DE GROOT, R.S., WILSON, M.A., BOUMANS, R.M.J. A typology for the classification, description and valuation of ecosystem functions, goods and services. Ecological Economics, v. 41,3, p. 393408, 2002.

DE GROOT et al. Challenges in integrating the concept of ecosystem services and values in landscape planning, management and decision making. Ecological Complexity 7, p. 260-272, 2010.

DOBBERT et al. Percepção e conforto dos usuários do Parque Trianon em São Paulo/SP. Revista LABVERDE V.8 № 2, artigo 3, p. 59-73, Agosto de 2017. Disponível em: < https://www.revistas.usp.br/revistalabverde/article/view/133252/133390> Acessado em: 10/11/2017.

DUARTE, D.H.S. et al. The impact of vegetation on urban microclimate to counterbalance built density in a subtropical changing climate. Urban Climate, 14, p. 224-239, 2015.

EDWARDS, P.N. Infrastructure and Modernity: Force, Time, and Social Organization in the History of Sociotechnical Systems. In: Modernity and Technology, MISA, T.J., BREY, P., FEENBERG, A. (eds.), MIT Press, p.185-220, 2002.

ELMQVIST et al. Benefits of restoring ecosystem services in urban areas. Current Opinion in Environmental Sustainability, 14:10, p.101- 108, 2015.

EC. European Common Indicators: towards a local sustainability profile. Ambiente Italia, Istituto di Ricerche, 2003.

FUNDAÇÃO CENTRO TECNOLÓGICO DE HIDRÁULICA (FCTH). Desenvolvimento de Metodologia e Projeto-Piloto de Revitalização de Bacia Urbana, Replicável para as demais Bacias da Região Metropolitana (Bacia do Córrego do Jaguaré) - Empreendimento 2014 At-653", 2017.

FORMAN, R.T.T., GODRON, M. Landscape Ecology. John Wiley and Sons Ltd., New York, 1986.

FRANCO, F.M. A construção do caminho: A estruturação da metrópole pela conformação técnica das várzeas e planícies fluviais da Bacia de São Paulo. Tese de doutorado, Programa de Pós-graduação em Arquitetura e Urbanismo, Universidade de São Paulo, 2005.

FRANCO, M. A. R. Desenho ambiental. Uma introdução à arquitetura da paisagem com o paradigma ecológico. São Paulo, Annablume, FAPESP, 2003. 
. Infraestrutura Verde em São Paulo: o caso do Corredor Verde Ibirapuera-Villa Lobos. Revista Labverde, n.1, p. 135-154, 2010. Disponível em: < http://www.revistas.usp.br/revistalabverde/article/view/61284 > Acesso em: 12/11/2016.

FRANCO, M. A. R. (org.). São Paulo nas Mudancas Climática, cenários ambientais para a Resiliência Urbana, 1a edição, São Paulo: Annablume, 2019.

FRY, G. Multifunctional Landscapes- Towards transdisciplinary research. Landscape and Urban Planning, 57, p. 159-168, 2001.

GEHL, J. Cities for people, Island Press, 2010.

GÓMEZ-BAGGETHUN, E. et al. Urban Ecosystem Services. In: ELMQVIST, T. et al. (eds.), Urbanization, Biodiversity and Ecosystem Services: Challenges and Opportunities: A Global Assessment, chap. 11, p. 175- 251, 2013.

GÓMEZ-BAGGETHUN, E., BARTON, D.N. Classifying and valuing ecosystem services for urban planning. Ecological Economics 86, p. 235-245, 2013.

GRUNEWALD et al. Proposal of indicators regarding the provision and accessibility of green spaces for assessing the ecosystem service "recreation in the city" in Germany. International Journal of Biodiversity Science, Ecosystem Services \& Management, 13:2, p. 26-39, 2017.

HAASE, D. et. al. A Quantitative Review of Urban Ecosystem Service Assessments: Concepts, Models, and Implementation. Ambio- A Journal of the Human Environment, Volume 43, Issue 4, p. 413-433, 2014.

HAGAN, S. Desempenhabilidade: sistemas de medição ambientais e planejamento urbano. In: MOSTAFAVI, M.; DOHERTY, G. (org.). Urbanismo Ecológico. São Paulo, Gustavo Gili, p. 458-467, 2014.

HAINES-YOUNG, R. e POTSCHIN, M. The links between biodiversity, ecosystem services and human well-being. In Ecosystem Ecology: a new synthesis 1, Chapter 6, p. 110- 138, 2010.

HANSEN, R. e PAULEIT, S. From Multifunctionality to Multiple Ecosystem Services? A Conceptual Framework for Multifunctionality in Green Infrastructure Planning for Urban Areas. Ambio- A Journal of the Human Environment, Volume 43, Issue 4, p. 516-529, 2014.

HERMANN, B. M.; HADDAD, E. A. Mercado imobiliário e amenidades urbanas: a view through the window. Estudos Econômicos, vol.35 no.2. São Paulo Abril/Junho, 2005.

HIRSCHHORN, L. Scenario Writing: A Developmental Approach. Journal of the American Planning Association, 46:2, 172-183, 1980. 
HOUGH, M. Cities and Natural Process. Routledge, New York, 1995

KAMBITES, C.J., OWEN, S. Renewed prospects for green infrastructure planning in the UK. Planning Practice and Research, v. 21, 4, p. 483-496, 2006.

KAPLAN, R. The analysis of perception via preference: a strategy for studding how the environment is experienced. Landscape Planning, 12, p. 161-176, 1985.

$\mathrm{KOH}$, J. Ecological Infrastructure: enabling Landscape Urbanism. Lecture at Wageningen University, 2011.

KONIJNENDIJK et al. Defining urban forestry - a comparative perspective of North America and Europe. Urban Forestry \& Urban Greening, 4(3-4), 93-103, 2006.

KOWARIK, I. Cities and Wildness, a new perspective. International Journal of Wilderness, v. 9, n. 3, p. 32-36, 2013.

LABOY, M. Landscape as a Conceptual Space for Architecture: Shifting Theories and Critical Practices, The Plan Journal, Volume 0/2016 - Issue 0 2016. Disponível em:

$<$ http://www.theplanjournal.com/article/landscape-conceptual-space-architecture-shiftingtheories-and-critical-practices\#note $9>$ Acesso em 10/05/2018.

LOCATELLI et al. Planejamento de Espaços Verdes para minimização do escoamento superficial das águas pluviais. Revista Labverde, v.8 n.2, p. 75-89,2017. Disponível em: < http://www.revistas.usp.br/revistalabverde/article/view/132763 > Acesso em: 12/12/2017.

LYLE, J. T. Regenerative Design for Sustainable Development. John Wiley and Sons Ltd., New York, 1994.

LYYTIMÄKI, J., SIPILÄ, M. Hopping on one leg-the challenge of ecosystem disservices for urban green management. Urban Forestry \& Urban Greening 8, 309-315, 2009.

MAHMOUND et al. A formal framework for scenario development in support of environmental decision-making. Environmental Modelling and Software 24(7):798-808, 2009.

MARQUES, T.H.N. A Infraestrutura Verde na gestão da energia. In: PELLEGRINO, P.R.M., MOURA, N.B. (org.) Estratégias para uma Infraestrutura Verde, 1a edição, São Paulo: Manole, p. 213-241, 2017a.

. O Potencial das Avenidas de Fundo de Vale para Receber a Infraestrutura VerdeAzul, Revista Labverde, V.8 № 2 - Artigo 02, p. 38-57, Agosto de 2017b. 
. A Paisagem Multifuncional no Fundos de Vale: estudo em transecto. In: São Paulo nas Mudanças Climática, cenários ambientais para a Resiliência Urbana, 1a edição, São Paulo: Annablume, p. 223-244, 2019.

MARQUES, T.H.N e BATISTELA, T. S. Percepção da Caminhabilidade no entorno da Interseção das Avenidas Engenheiro Caetano Álvares e Imirim, Revista Labverde, V. II № 12 - Artigo 06, p. 150-177, 2016. Disponível em: < https://www.revistas.usp.br/revistalabverde/article/view/117585 > Acesso em: 15/12/2017.

MARQUES et al. De canais de drenagem a Paisagens Multifuncionais: uma nova geração de parques lineares para São Paulo. II Simpósio de Revitalização de Rios Urbanos, Faculdade de Engenharia da Universidade de São Paulo, São Paulo, 26 e 27 de outubro de 2017.

MARQUES et al. Projeto Jaguaré: Metodologia para requalificação de bacias hidrográficas urbanas. Revista Labverde, v. 9 n.1, p.12-27, 2018. Disponível em: < http://www.revistas.usp.br/revistalabverde/article/view/143742> Acesso em: 20/11/2018. MCHARG, I. Designing with Nature, 1969.

MA. Millennium ecosystem assessment: Ecosystems and human well-being: Synthesis. Washington, DC: Island Press, 2005.

LEITÃO, A. B. et al. Measuring Landscape: a planner's handbook. Washington, DC: Island Press, 2006.

MELL, I.C. Green Infrastructure: concepts and planning. FORUM E journal 8 (June 2008): 69-80 Newcastle University. 1354-5019, 2008.

. Green infrastructure: reflections on past, present and future praxis, Landscape Research, 42:2, 135-145, 2017.

MOSTAFAVI, M.; DOHERTY, G. (org.). Urbanismo Ecológico. São Paulo, Gustavo Gili, 2014.

MOURA, et al. Intelligent Landscapes: Application of Parametric Modeling for a New Generation of Flood Risk Management Reservoirs in São Paulo city. Co-Design: digital tools for knowledgebuilding and decision-making, v. 11, n. 20, p. 1- 15, 2018. Disponível em: < http://disegnarecon.univaq.it/ojs/index.php/disegnarecon/issue/view/23> Acesso em: 09/02/2020.

NASSAUER, J. I., CORRY, R.C. Using normative scenarios in landscape ecology. Landscape Ecology 19: 343-356, 2004.

NATURE ENGLAND. Nature Nearby, Accessible Natural Greenspace Guidance. 2010. Disponível em: 
<https://webarchive.nationalarchives.gov.uk/20140605145320/http://publications.naturalengla nd.org.uk/publication/40004?category=47004 >. Acessado em 10/01/2018.

NAVEH, Z. Ten major premises for a holistic conception of multifunctional landscapes.

Landscape and Urban Planning, Volume 57, Issues 3-4, 15, Pages 269-284. December 2001.

NEWMAN, P.W.G. Sustainability and cities: extending the metabolism mode. Landscape and

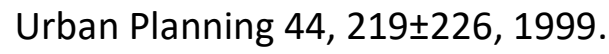

NOWAK, D.J. E DWYER, J.F. Understanding the benefits and costs of urban forest ecosystems. In: KUSER, J. E. (ed.). Urban and Community Forestry in the Northeast, 2nd ed., Springer, p. 25-46, 2007.

NUCCI, J.C. Qualidade Ambiental e adensamento urbano: Um estudo de Ecologia e Planejamento da Paisagem aplicado ao distrito de Santa Cecília (MSP). Curitiba, 2ª edição, 0 Autor, 2008.

O'FARRELL, P. J. e PIPPIN, M. L. A. Sustainable multifunctional landscapes: a review to implementation. Current Opinion in Environmental Sustainability, Volume 2, Issues 1-2, p. 5965, 2010.

PAULEIT et al. Urban Landscapes and Green Infrastructure. Oxford Research Encyclopedia of Environmental Science, p. 1-53, 2017.

PELLEGRINO, P.R.M. Conclusão. In: PELLEGRINO, P.R.M., MOURA, N.B. (org.). Estratégias para uma Infraestrutura Verde, 1a edição, São Paulo: Manole, p. 291-308, 2017 a.

. Paisagem como Infraestrutura Ecológica: a floresta urbana. In: PELLEGRINO, P.R.M., MOURA, N.B. (org.) Estratégias para uma Infraestrutura Verde, 1a edição, São Paulo: Manole, p. 63-77, 2017b.

PLANMOB/SP. Plano de Mobilidade de São Paulo. 2015

PMSP. Diretrizes Básicas para Projetos de Drenagem Urbana no Município de São Paulo. Fundação Centro Tecnológico de Hidráulica, 1999.

. Atlas Ambiental do município de São Paulo, Fase I: diagnóstico e bases para a definição de políticas públicas para as áreas verdes no município de São Paulo, Relatório Final, Julho de 2002.

. Precipitação Pluviométrica do Município de São Paulo, 1933 a 2019. Disponível em:

<https://www.prefeitura.sp.gov.br/cidade/secretarias/upload/chamadas/2 precipitacao pluvio metrica 193310711 1582136188.htm> Acessado em: 10/01/2020. 
. Índice de Desenvolvimento Humano do Município- IDH-M, 2017.

<https://www.prefeitura.sp.gov.br/cidade/secretarias/upload/Informes Urbanos/29 Dimensoe s IDH-M.pdf> Acesso em: 05/12/2018.

PIVETTA, J. Influência de elementos paisagísticos no desempenho térmico de edificação térrea. Universidade Estadual de Londrina Programa de Pós-graduação em Engenharia de Edificações e Saneamento. Londrina, 2010.

PIVETTA, M. Da garoa à tempestade: temporais se tornam mais frequentes e chuva aumenta 30\% em São Paulo em 80 anos. Revista Pesquisa FAPESP, São Paulo, ed. 195, maio 2012.

RIECHERS, M., BARKMANN, J.; TSCHARNTKE,T. Perceptions of cultural ecosystem services from urban green. Ecosystem Services, 17, p. 33-39, 2016.

RIO DE JANEIRO (Estado). Secretaria de Estado de Meio Ambiente e Desenvolvimento Sustentável. Revitalização de rios: orientação técnica. Rio de Janeiro: SEMADS, 2001. (Projeto Planagua Semads GTZ, de Cooperação Técnica Brasil/Alemanha).

RIZZI, et. al. Collaborative work between landscape architects and hydraulic engineers to propose Green Infrastructure in an urbanized water basin in São Paulo. ICUD, 2017.

ROCHA, M. F.; NUCCI, J. C. Índices de vegetação e competitividade entre cidades. GEOUSP Espaço E Tempo (Online), 22(3), p. 641-655. 2018. Disponível em: < http://www.revistas.usp.br/geousp/article/view/133554> Acesso em: 10/10/2019.

RODRIGUES, C. Atributos ambientais no ordenamento territorial urbano: o exemplo das planícies fluviais na metrópole de São Paulo. Geousp - Espaço e Tempo (Online), v. 19, n. 2, p. 325-348, ago. 2015.

ROSSMAN, L.A. e HUBER, W. C. Storm Water Management Model Reference Manual. Volume III- Water Quality. EPA. Cincinnati. USA, 2016.

RUEDA, S. El urbanismo ecológico. Urban-e, 2001. Disponivel em: $<\underline{\text { http://urban- }}$ e.aq.upm.es/articulos/ver/el-urbanismo-ecol-gico/completo> Acesso em 30/05/2019.

SABESP. Programa Córrego Limpo: Despoluição de Córregos em áreas Urbanas. 2012.

SCHUTZER, J.G. Dispersão urbana e apropriação do relevo na Macrometrópole de São Paulo. Tese de doutorado, Departamento de Geografia da Faculdade de Filosofia, Letras e Ciências Humanas da Universidade de São Paulo, 2012. 
. Resiliência Urbana em São Paulo: Questões Geomorfológicas. In: FRANCO, M.A.R. (org.), São Paulo nas Mudanças Climática, cenários ambientais para a Resiliência Urbana, 1a edição, São Paulo: Annablume, p. 31-59, 2019.

SCOTT, M. e LENNON, M. Nature-based solutions for the contemporary city/Re-naturing the city. Planning Theory and Practice, vol. 17, n. 2, p. 267-300, 2016.

SELMAN, P. Planning for landscape multifunctionality. Journal in Sustainability: Science, Practice \& Policy. Community Essay, volume 5, issue 2, 2009.

SILVA, J.M.C., Wheeler, E. Ecosystems as infrastructure. Perspectives in Ecology and Conservation 15, 32-35, 2017.

SMDU. Manual de drenagem e manejo das águas pluviais, aspectos tecnológicos, volume II. São Paulo, 2012.

. Caderno de Bacia Hidrográfica: Córrego Mandaqui. 2016. Disponível em:< https://www.prefeitura.sp.gov.br/cidade/secretarias/obras/upload/arquivos/mandaqui.pdf> Acesso em:03/02/2017.

STEINER, F. Human Ecology, following nature's lead. Washington: Island Press, 2002.

STEINITZ, C. A Framework for theory applicable to the education of landscape architects (and other design professionals). Landscape Journal, 9, 2, p. 136-143, 1990.

STREMKE, S. Designing sustainable energy landscapes, concepts principles and procedures. 2010, 202 p. Ph. D Thesis, Landscape Architecture and Planning Program, Wageningen University, Holanda, 2010.

TEEB. The Economics of Ecosystems and Biodiversity in National and International Policy Making. Patrick ten Brink, ed, 2011. Disponível em:

<http://www.teebweb.org/publication/teeb-in-national-and-international-policy-making/>. Acessado em 10/09/2017.

TOMAZ, P. Critério unificado para manejo das águas pluviais em áreas urbanas, 2007.

TRAVASSOS, L. R. F.C. A Dimensão socioambiental da ocupação dos fundos de vale urbanos do município de São Paulo, Dissertação de Mestrado, Programa de Pós-Graduação em Ciência Ambiental Universidade de São Paulo, 2004.

- Revelando os rios, novos paradigmas para a intervenção em fundos de vale urbanos na cidade de São Paulo, tese de doutorado, Programa de Pós-Graduação em Ciência Ambiental, Universidade de São Paulo, 2010. 
TRESS, G. TRESS, B. e FRY, G. Clarifying integrative research concepts in landscape ecology. Landscape Ecology, 20, p. 479-493, 2004.

TURKELBOOM, F. et. al. Ecosystem services trade-offs and synergies (draft). In: Potschin, M. and K. Jax (eds): OpenNESS Ecosystem Services Reference Book. EC FP7 Grant Agreement no. 308428. 2016. Disponível em: <www.openness-project.eu/library/reference-book>. Acessado em 10/09/2017.

TZOULAS, K. et al. Promoting Ecosystem and Human Health in Urban Areas Using Green Infrastructure: A Literature Review. Landscape and Urban Planning, 81, p. 167-178, 2007.

UACDC. Low Impact Development: a design manual for the urban areas. Arkansas University, 2010.

VALASKI, S. Estrutura e dinâmica da paisagem: subsídios para a participação popular no desenvolvimento urbano do município de Curitiba-PR. Tese de doutorado, Programa de Pósgraduação em Geografia, Setor de Ciências da Terra, Universidade Federal do Paraná, 2013.

WAGNER, I., KRAUZE, K., ZALEWSKI, M. Blue aspects of green infrastructure. European Regional Centre for Ecohydrology under the auspices of UNESCO Polish Academy of Sciences, 2013.

WALDHEIM, C. (org.). The Landscape Urbanism Reader. New York: Princeton Architectural Press, 2006.

Wu, J. et al. Impact of Urban Green Space on Residential Housing Prices: Case Study in Shenzhen. Journal of Urban Planning and Development/ Volume 141 Issue 4 - December 2015.

WLO. Urban Green Spaces and Health, a review of evidence. Copenhagen: WHO Regional Office for Europe, 2016.

WRI. Infraestrutura Natural Para Água No Sistema Cantareira, São Paulo. 2018. Disponível em: < https://wribrasil.org.br/sites/default/files/InfraestruturaNaturalCantareiraSP.pdf> Acessado: 01/02/2019.

Websites consultados:

American Society of Landscape Architecture, ASLA. Disponível em: <https://www.asla.org/> Acessado em 15/01/2017

Departamento de Água e Energia Elétrica, DAEE. Disponível em: <http://www.daee.sp.gov.br/> Acesso em 22/06/2018. 
De Urbanisten. Disponível em:< http://www.urbanisten.nl/wp/?page id=47> Acesso em: $10 / 05 / 2017$

European Commission, EC. Towards an EU Research and Innovation policy agenda for NatureBased Solutions \& Re-Naturing Cities, 2015. Disponível em:< https://ec.europa.eu/programmes/horizon2020/en/news/towards-eu-research-and-innovationpolicy-agenda-nature-based-solutions-re-naturing-cities>Acesso em: 17/07/2016.

Geosampa. Disponível em:<http://geosampa.prefeitura.sp.gov.br/PaginasPublicas/ SBC.aspx\#>. Acesso em 01/04/2016.

Instituto de Políticas de Transporte e Desenvolvimento,ITDP. Disponível em:

<https://itdpbrasil.org/> Acesso em: 03/04/2017

Lei de Parcelamento, Uso e Ocupação do Solo, LPUOS, 2016. Disponível em: < https://www.prefeitura.sp.gov.br/cidade/secretarias/licenciamento/legislacao/index.php?p=22 8327> Acesso em: 17/10/2017.

Ministério del Ambiente, MINAM. Disponível em: <https://www.gob.pe/minam> Acesso em: $15 / 03 / 2018$.

Ministério do Meio Ambiente, MMA. Disponível em: <https://www.mma.gov.br/> Acesso em: 02/02/2019.

Plano Diretor Estratégico, PDE, 2014. Disponível em: <https://gestaourbana.prefeitura.sp.gov.br/marco-regulatorio/plano-diretor/> Acesso em 10/07/2016.

Portal do Governo. Conjunto Hospitalar do Mandaqui passa a atender 10 mil pessoas por mês: Secretaria de Estado da Saúde acaba de entregar a ampliação do "Hospital das Clínicas da zona norte", como é conhecido o Conjunto Hospitalar do Mandaqui, 25/07/2007, Disponível em: <http://www.saopaulo.sp.gov.br/ultimas-noticias/conjunto-hospitalar-do-mandaqui-passa-aatender-10-mil-pessoas-por-mes/> Acesso em: 02/03/2017.

Secretaria do Verde e Meio Ambiente, SVMA. Mapeamento dos Remanescentes do Bioma Mata Atlântica no Município de São Paulo - PMMA SÃO PAULO. Disponível em:

<http://www.prefeitura.sp.gov.br/cidade/secretarias/meio ambiente/pmma/index.php?p=219 941> Acesso em 02/10/2018.

Studio Dreiseitl. Disponível em:< http://www.dreiseitl.com/en> Acesso em: 02/05/2017

U.S. Environmental Protection Agency, EPA. Disponível em: <https://www.epa.gov/greeninfrastructure> Acesso em: 02/10/2016. 
União Internacional para a Conservação da Natureza (UICN). Disponível em: $<$ https://www.iucn.org/es/comisiones/commission-ecosystem-management/solucionesbasadas-en-la-naturaleza> Acesso em:05/07/2018. 


\section{ANEXO 1- DEFINIÇÃO DE PRINCÍPIOS DA INFRAESTRUTURA VERDE}

\section{URBANA}

Quadro 22: Princípios para o Planejamento da Infraestrutura Verde.

\begin{tabular}{|c|c|c|}
\hline \multicolumn{3}{|c|}{ Princípios para o Planejamento da Infraestrutura Verde } \\
\hline Benedict e McMahon (2002; 2006) & Davies et al. (2006) & Kambites e Owen (2006) \\
\hline $\begin{array}{l}\text { 1. Pode e deveria funcionar como } \\
\text { uma estrutura para a conservação } \\
\text { e o desenvolvimento. }\end{array}$ & $\begin{array}{l}\text { 1. Envolve áreas verdes } \\
\text { naturais e manipuladas, } \\
\text { urbanas e rurais }\end{array}$ & 1. Planejamento Abrangente \\
\hline $\begin{array}{l}\text { 2. Deve ser planejada e protegida } \\
\text { antes do desenvolvimento }\end{array}$ & $\begin{array}{c}\text { 2. Trata da conexão } \\
\text { estratégica entre espaços } \\
\text { abertos verdes }\end{array}$ & 2. Agrupamento de informações \\
\hline 3. Conectividade é chave & $\begin{array}{l}\text { 3. Deve fornecer múltiplos } \\
\text { benefícios para as pessoas }\end{array}$ & $\begin{array}{l}\text { 3. Abordagem holística (áreas } \\
\text { verdes devem estar conectadas em } \\
\text { uma rede de corredores; todas as } \\
\text { esferas de autoridades locais devem } \\
\text { estar envolvidas; deve ser } \\
\text { multifuncional, beneficiando } \\
\text { pessoas e vida selvagem). }\end{array}$ \\
\hline $\begin{array}{l}\text { 4. Funciona através de múltiplas } \\
\text { jurisdições e em diferentes escalas }\end{array}$ & 4. Integração verde e cinza & $\begin{array}{l}\text { 4. Ligações (entre áreas naturais, } \\
\text { entre pessoas e programas) }\end{array}$ \\
\hline $\begin{array}{c}\text { 5. Deve ser baseada em ciência e } \\
\text { teorias e práticas de planejamento } \\
\text { do uso do solo }\end{array}$ & & 5. Envolvimento da comunidade \\
\hline $\begin{array}{l}\text { 6. IV é um investimento público } \\
\text { crítico que deve ser financiado à } \\
\text { frente }\end{array}$ & & 6. Necessidades Recreacionais \\
\hline 7. IEV envolve diversos atores & & 7. Preservação e conservação \\
\hline $\begin{array}{l}\text { 8. IV oferece benefícios para a } \\
\text { natureza e as pessoas }\end{array}$ & & 8. Respeito pelo lugar \\
\hline $\begin{array}{c}\text { 9. IV respeita as necessidades e } \\
\text { desejos dos donos de terra e atores }\end{array}$ & & $\begin{array}{l}\text { 9. Características locais } \\
\text { diferenciadoras }\end{array}$ \\
\hline $\begin{array}{l}\text { 10. IV requer fazer conexões com } \\
\text { atividades que estão na e além a } \\
\text { comunidade }\end{array}$ & & 10. Financiamento sustentável \\
\hline \multicolumn{3}{|l|}{$\begin{array}{l}\text { 11. IV requer comprometimento a } \\
\text { longo prazo }\end{array}$} \\
\hline 12. Contexto Importa & & \\
\hline
\end{tabular}

Fonte: elaborado pela autora a partir de pesquisa bibliográfica. 
Quadro23: Princípios para o Planejamento da Infraestrutura Verde Urbana

\begin{tabular}{|c|c|c|}
\hline \multicolumn{3}{|c|}{ Princípios para o Planejamento da Infraestrutura Verde Urbana } \\
\hline & $\begin{array}{l}\text { Infraestrutura Verde como } \\
\text { estratégia para a água urbana }\end{array}$ & $\begin{array}{c}\text { Destaque de FRANCO a partir de } \\
\text { Benedict e McMahon (2006) para } \\
\text { aplicação em corredor verde } \\
\text { urbano }\end{array}$ \\
\hline Ahern (2007) & Cormier e Pellegrino (2008) & Franco (2010) \\
\hline 1. Multi escalar & $\begin{array}{l}\text { 1. Multi escalar ( a partir da } \\
\text { bacia hidrográfica) }\end{array}$ & 1. Conectividade \\
\hline $\begin{array}{l}\text { 2. Relação entre padrões e } \\
\text { processos (conexão física e } \\
\text { funcional) }\end{array}$ & $\begin{array}{l}\text { 2. Multifuncional (regulação da } \\
\text { água, do clima, etc.) }\end{array}$ & 2. Contexto \\
\hline $\begin{array}{l}\text { 3. Diretrizes para o planejamento } \\
\text { espacial das paisagens }\end{array}$ & $\begin{array}{l}\text { 3. Conexão e identificação dos } \\
\text { moradores com a Infraestrutura } \\
\text { Verde }\end{array}$ & 3. Estrutura \\
\hline 4. Articular conceito espacial & 4. Identidade regional & 4. Comprometimento \\
\hline 5. Pensamento Estratégico & $\begin{array}{l}\text { 5. Integração com a paisagem } \\
\text { local }\end{array}$ & \\
\hline 6. O verdejar das infraestruturas & $\begin{array}{l}\text { 6. Integração sistemas naturais e } \\
\text { tradicionais de drenagem }\end{array}$ & \\
\hline 7. Planejar para multiplos usos & & \\
\hline 8. Aprender fazendo & & \\
\hline
\end{tabular}

Fonte: elaborado pela autora a partir de pesquisa bibliográfica. 


\section{ANEXO 2- TABELA COMPARATIVA PARA ACESSIBILIDAE ÀS ÁREAS \\ VERDES.}

Quadro 24: Tabela comparativa entre indicadores de acessibilidade às áreas verdes.

\begin{tabular}{|c|c|c|c|}
\hline Referência & Categoria & Área mínima & $\begin{array}{l}\text { Distancia da } \\
\text { Residência } \\
\end{array}$ \\
\hline \multirow{12}{*}{$\begin{array}{c}\text { JANTZEN, F. et al., } \\
\text { 1973, apud } \\
\text { CAVALHEIRO e DEL } \\
\text { PICCHIA, 1992, p. } 4 .\end{array}$} & Vizinhança & & \\
\hline & Até 6 anos & $150 \mathrm{~m}^{2}$ & $100 \mathrm{~m}$ \\
\hline & 06-10 anos & $450 \mathrm{~m}^{2}$ & $500 \mathrm{~m}$ \\
\hline & 10-17 anos & $5000 \mathrm{~m}^{2}(0,5 \mathrm{ha})$ & $1000 \mathrm{~m}$ \\
\hline & Parque de bairro & 10 ha & $1000 \mathrm{~m}$ ou $10 \mathrm{~min}$ \\
\hline & Parque distrital & 100 ha & $\begin{array}{c}1200 \mathrm{~m} \text { ou } 30 \mathrm{~min} . \\
\text { Veículo }\end{array}$ \\
\hline & Parque Regional & 200 ha com água & $\begin{array}{c}\text { qualquer parte da } \\
\text { cidade }\end{array}$ \\
\hline & Cemitério & s/ referencia & s/ referencia \\
\hline & Área para esporte & $\begin{array}{c}\text { 3-5 ha para cada } 1500 \\
\text { hab. }\end{array}$ & Perto escolas \\
\hline & Balneário & 2 há para cada 0,2 hab. & Perto escolas \\
\hline & $\begin{array}{c}\text { Horta } \\
\text { comunitária }\end{array}$ & $300 \mathrm{~m}^{2}$ & s/ ref. \\
\hline & Verde viário & s/ref. & Junto ao viário \\
\hline \multirow{4}{*}{$\begin{array}{l}\text { Natural England } \\
\qquad(2010)\end{array}$} & \multirow{4}{*}{$\begin{array}{c}\text { áreas verdes } \\
\text { naturais }\end{array}$} & 2-20 ha & $300 \mathrm{~m}$ \\
\hline & & 20-100 ha & $2000 \mathrm{~m}$ \\
\hline & & $100-500$ ha & $5000 \mathrm{~m}$ \\
\hline & & $>500$ ha & $10000 \mathrm{~m}$ \\
\hline ISTAT, 2003 & - & $>0.5 \leq 1 \mathrm{ha}$ & $300 \mathrm{~m}$ \\
\hline
\end{tabular}

Fonte: elaborado pela autora a partir de Jantzen et al., (1973), apud Cavalheiro e Del Picchia, (1992); ISTAT, (2003); Natural England, (2010). 


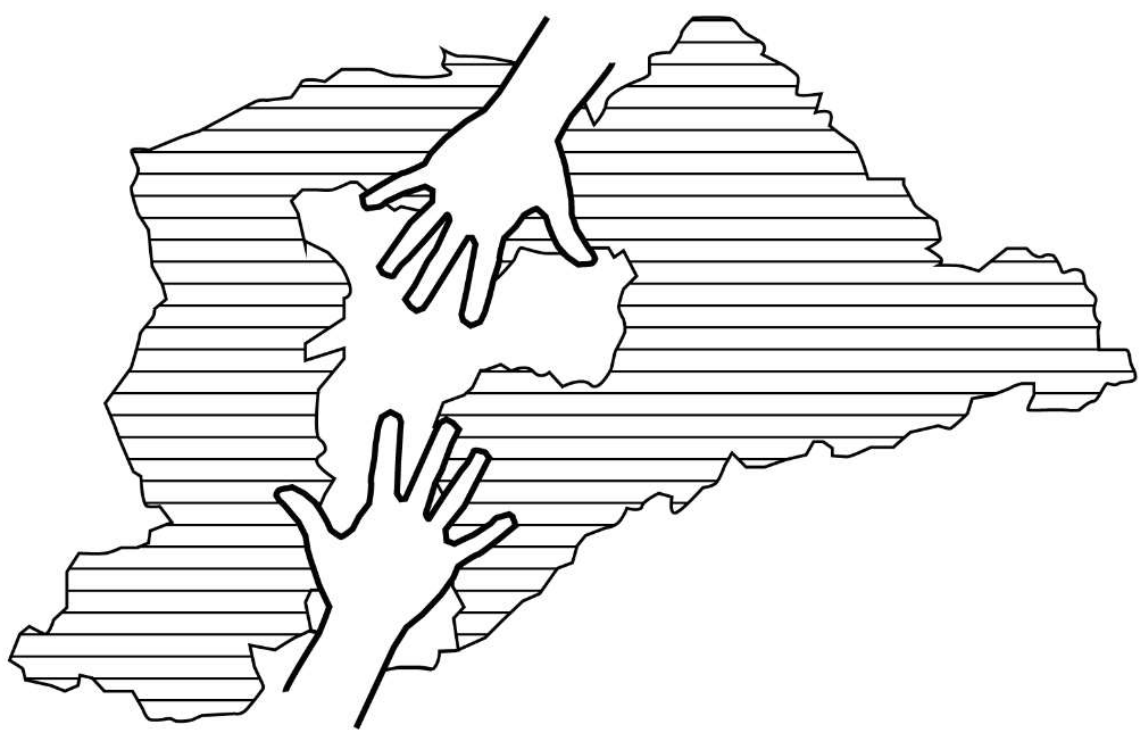

